\title{
Regiones HII Gigantes en Galaxias Observables desde el Hemisferio Sur
}

\section{Verónica Firpo}

\author{
Director de Tesis: Dr. Guillermo L. Bosch \\ Co-director de Tesis: Dr. Guillermo F. Hägele
}

Tesis presentada para optar al grado de Doctor en Astronomía

Facultad de Ciencias Astronómicas y Geofísicas

Universidad Nacional de La Plata

Argentina

Marzo de 2011 



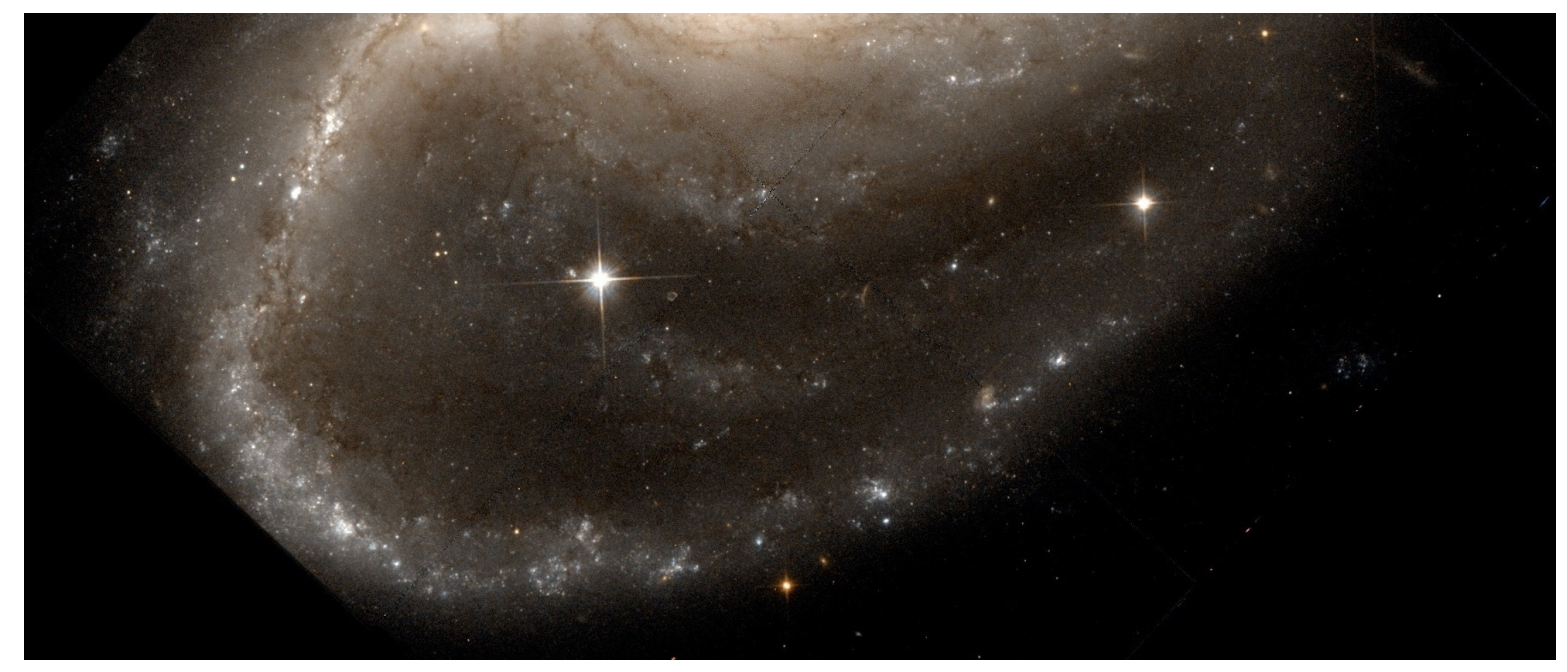

"Una mota solitaria en la inmensa oscuridad cósmica." Carl Sagan (referenciando a la Tierra) 
La imágen anterior corresponde a la galaxia NGC7479.

Basada en observaciones realizadas con el Telescopio Espacial Hubble, NASA/ESA, y obtenida del Hubble Legacy Archive, en colaboración entre Space Telescope Science Institute (STScI/NASA), Space Telescope European Coordinating Facility (ST-ECF/ESA) y Canadian Astronomy Data Centre (CADC/NRC/CSA). 
A mis padres

por su inagotable paciencia y comprensión.

$Y$ al resto de mi familia

por el incondicional apoyo en todos estos años. 



\section{Resumen}

En esta Tesis presento un estudio espectroscópico detallado de una muestra de Regiones Hiı Gigantes en galaxias observables con telescopios del Hemisferio Sur.

Las Regiones Hir Gigantes proveen el vínculo entre regiones de formación estelar de menor escala y los violentos procesos de formación estelar que ocurren en las galaxias con brotes estelares intensos. Las Regiones Hir Gigantes (GHirRs, de sus siglas en inglés) son objetos extendidos y luminosos, observados en los discos de galaxias espirales, irregulares y galaxias enanas compactas azules (BCDs, de su sigla en inglés). Las GHıRs se forman debido a la presencia de un gran número de estrellas jóvenes y masivas cuyo flujo ultravioleta ioniza el gas que las rodea, y por lo tanto estas regiones indican una presencia de formación estelar violenta reciente o activa. El principal objetivo de este trabajo de Tesis es confirmar la presencia de Regiones HiI Gigantes en galaxias del Universo Local y realizar un estudio comparativo de GHIIRs con distintas metalicidades y estados evolutivos.

La identificación de Regiones Hir Gigantes fue posible realizarla mediante espectroscopía de alta resolución, la cual me ha permitido distinguir la presencia de distintas componentes cinemáticas en el gas ionizado, con diferentes velocidades y verificar la naturaleza supersónica de dichas componentes.

Definir la naturaleza y condiciones físicas de los brotes de formación estelar masiva permite analizar las abundancias químicas que producen el enriquecimiento químico del Universo Local. Para poder caracterizar los procesos físicos que gobiernan la formación estelar masiva es necesario estudiar un variado rango de entornos y propiedades. Gracias al amplio rango espectral y la buena calidad de los datos he llevado adelante el estudio de las propiedades físicas del gas ionizado. El estudio de los parámetros físicos tales como densidad, temperatura, composición química, etc., comprende el análisis de las intensidades relativas de las líneas de emisión del gas. Este tipo de análisis resulta esencial para poder mejorar el estudio de brotes de formación estelar detectados a distancias cosmológicas.

En esta Tesis se presenta el estudio realizado en seis regiones brillantes de las galaxias espirales, NGC 6070 y NGC 7479, y en cinco brotes de formación estelar de la galaxia enana compacta azul Haro 15.

En el Capítulo 1 presento una breve introducción de las propiedades generales de las Regiones Hir Gigantes y del conocimiento que se tiene sobre este tipo de objetos. En el Capítulo 
II

2 propongo un método para proceder a un análisis detallado de la cinemática en aquellas regiones que presentan más de una componente revelada cinemáticamente en los espectros de alta resolución. En ese capítulo presento el análisis cinemático de las seis regiones estudiadas en las dos galaxias espirales y se analiza cómo la presencia de múltiples componentes cinemáticas influye en la ubicación final en el plano L- $\sigma$. En el Capítulo 3 presento un análisis cinemático utilizando una metodología similar que en el capítulo anterior, pero ahora enfocado en los brotes de formación estelar violentos de la galaxia BCD Haro 15. Del análisis cinemático detallado en los brotes estudiados con más de una componente, se deriva el estudio de las propiedades físicas y abundancias químicas presentado en el Capítulo 4. En este capítulo, sumado a los datos espectroscópicos de alta resolución, presento datos de baja resolución espectral observados en la misma galaxia. Aplicando el método propuesto por el Grupo de Astrofísica del Departamento de Física Teórica de la Universidad Autónoma de Madrid, España (UAM), para la determinación de los parámetros físicos y abundancias, a partir de un programa generado por dicho grupo, realicé un cuidadoso y detallado estudio sobre las propiedades físicas, y abundancias químicas iónicas y totales del gas ionizado discriminado para cada componente cinemática y para el flujo global de las líneas de emisión. En el Capítulo 5 se presentan las conclusiones finales de la Tesis, haciendo un conciso resumen sobre los aportes más significativos, y se describen las líneas de trabajo a futuro que se pueden plantear como continuación de lo aquí expuesto. 


\section{Prefacio}

Parte de esta Tesis ha sido publicada:

- Capítulo 2 ha sido publicado en

Firpo, V., Bosch, G., Hägele, G. F., Morrell, N., 2010. Monthly Notices of the Royal Astronomical Society, Volume 406, Issue 2, pp. 1094-1107.

- Capítulo 3 ha sido enviado para su publicación en

Firpo, V., Bosch, G., Hägele, G. F., Díaz, A. I., Morrell, N., 2011. Monthly Notices of the Royal Astronomical Society, aceptado.

El Capítulo 4 será enviado a la revista Monthly Notices of the Royal Astronomical Society para su publicación en 2011. Hägele, G. F., Firpo, V., Bosch, G., Díaz, A. I., Morrell, N..

Proceedings de conferencias:

- Capítulo 2

Giant Extragalactic HII Regions in the Southern Sky.

Firpo, V., Bosch, G., Morrell, N. I., 2006. Revista Mexicana de Astronomía y Astrofísica Conference Series, Vol. 26 de RMxAA, vol. 27, pp 160-+

Massive star formation in external galaxies: new giant $\mathrm{HII}$ regions.

Firpo, V., Bosch, G., Morrell, N. I., 2008. Revista Mexicana de Astronomía y Astrofísica Conference Series, Vol. 33 de RMxAA, vol. 27, pp 171-171

- Capítulo 3 y Capítulo 4

Haro15: Is it actually a low metallicity galaxy?.

Firpo, V., Bosch, G., Hägele, G. F., Díaz, A. I., Morrell, N., 2010. K. Cunha, M. Spite, 6 B. Barbuy (ed.), IAU Symposium, Vol. 265 of IAU Symposium, pp 243-244 
Internal kinematic and physical properties in a BCD galaxy: Haro 15 in detail. Firpo, V., Bosch, G., Hägele, G. F., Díaz, A. I., Morrell, N., 2010. ArXiv e-prints. Será publicado por la Sociedad Española de Astronomía, en motivo del IX Encuentro Científico de la Sociedad Española de Astronomía realizado del 13-17 de Septiembre de 2010, en Madrid, España.

Verónica Firpo

La Plata, Argentina, Marzo, 2011. 


\section{Índice general}

Resumen I

$\begin{array}{lll}\text { Prefacio } & \text { III }\end{array}$

1. Generalidades 1

1.1. Características de las GHirRs . . . . . . . . . . . . . . . . . 4

1.2. Motivación y Objetivos . . . . . . . . . . . . . . . 8

2. Regiones HiI Gigantes en NGC 7479 \& NGC $6070 \quad 13$

2.1. Resumen de la publicación . . . . . . . . . . . . . . . . . . . . . 13

2.2. Fundamentos básicos . . . . . . . . . . . . . . . . . . . . . 14

2.3. Herramientas utilizadas . . . . . . . . . . . . . . . . . . . . 14

2.4. Metodología en la cinemática . . . . . . . . . . . . . . 15

2.5. Dispersión de velocidades . . . . . . . . . . . . . . . . 16

3. Espectroscopía de alta resolución de la galaxia BCD Haro 15: Cinemática interna 33

3.1. Resumen de la publicación . . . . . . . . . . . . . . . . . . . 33

3.2. Fundamentos básicos . . . . . . . . . . . . . . . . . . . . . 34

3.3. Herramientas utilizadas . . . . . . . . . . . . . . . . . . 35

3.4. Metodología en la cinemática . . . . . . . . . . . . . . . . 36

4. Espectroscopía de alta resolución de la galaxia BCD Haro 15: Determinación de abundancias $\quad 49$

4.1. Introducción . . . . . . . . . . . . . . . . . . . . . . . 49

4.2. Observaciones y Reducción de los datos . . . . . . . . . . . . . . . . 52

4.3. Resultados . . . . . . . . . . . . . . . . . . . . . . 54

4.4. Análisis de Abundancias . . . . . . . . . . . . . . . . . . 65

4.4.1. Propiedades físicas del gas ionizado . . . . . . . . . . . . . 66

4.4.2. Derivación de las abundancias químicas . . . . . . . . . . . . . 75

4.5. Discusión . . . . . . . . . . . . . . . . . . . . . . . . 79 
4.5.1. Datos de ranura larga . . . . . . . . . . . . . . . . . 79

4.5.2. Datos échelle . . . . . . . . . . . . . . . . . 83

4.5.3. Estructura de ionización . . . . . . . . . . . . . . . . . . . 90

4.5.4. Abundancias químicas usando parámetros empíricos . . . . . . . . . 95

4.6. Resumen y conclusiones . . . . . . . . . . . . . . . . . . . . . . . 104

$\begin{array}{ll}\text { Conclusiones y Trabajo a futuro } & 109\end{array}$

$\begin{array}{ll}\text { Bibliografía } & 119\end{array}$

$\begin{array}{ll}\text { Agradecimientos } & 121\end{array}$ 


\section{Índice de tablas}

4.1. Observaciones . . . . . . . . . . . . . . . . . . . . . . . 54

4.2. Líneas de emisión medidas en el espectro de ranura larga en los brotes B y C 61

4.3. Líneas de emisión medidas en el espectro échelle en el brote A . . . . . . . . . 62

4.4. Líneas de emisión medidas en el espectro échelle en el brote B . . . . . . . . . 63

4.5. Líneas de emisión medidas en el espectro échelle en el brote C . . . . . . . . . 64

4.6. Líneas de emisión medidas en el espectro échelle en el brote E . . . . . . . . . 64

4.7. Líneas de emisión medidas en el espectro échelle en el brote F . . . . . . . . . 65

4.8. Cocientes de líneas de emisión . . . . . . . . . . . . . . . . . . . 66

4.9. Ecuaciones para el cálculo de las abundancias de las líneas prohibidas. . . . . 77

4.10. Propiedades físicas, abundancias químicas iónicas y totales, brotes $\mathrm{B}$ y $\mathrm{C}$ de dispersión simple . . . . . . . . . . . . . . . . 80

4.11. Propiedades físicas, abundancias químicas iónicas y totales, brotes A, B, C, E y F de échelle . . . . . . . . . . . . . . . . . . . . 81

4.12. $\log \eta \mathrm{y} \log \eta^{\prime}$ de $\operatorname{los}$ brotes $\mathrm{A}$ y B . . . . . . . . . . . . 93 



\section{Índice de figuras}

1.1. Imagen $\mathrm{H} \alpha$ de la Nebulosa de la Tarántula 30 Doradus . . . . . . . . . . . . . 2

1.2. Imagen $\mathrm{H} \alpha$ de la Nebulosa de Orión (M42) . . . . . . . . . . . . . . . . . 3

1.3. Dibujo esquemático que simula la geometría de las capas de mezcla turbulenta 4

1.4. Regresión en el plano Luminosidad (L) vs. Dispersión de Velocidades $(\sigma)$ de

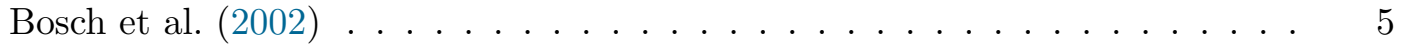

1.5. Dibujo esquemático que simula el estado del ISM en la galaxia M82 . . . . 6

1.6. Ajuste de dos componentes en el perfil de emisión de $H \beta$ (Hägele et al., 2010) 7

1.7. Imagen de la galaxia $\mathrm{NGC} 6070 \ldots \ldots$. . . . . . . . . . . . . . 9

1.8. Imagen de la galaxia NGC $7479 \ldots \ldots$. . . . . . . . . . . . . . . 10

1.9. Imagen de la galaxia Haro $15 \ldots \ldots$. . . . . . . . . . . . . . . 10

4.1. Espectros de líneas de emisión de ranura larga . . . . . . . . . . . . . 55

4.2. Comparación entre las soluciones de distintos ajustes, brote A . . . . . . . 58

4.3. Comparación entre las soluciones de distintos ajustes, brote B . . . . . . . . . 59

4.4. Abundancias relativas al oxígeno . . . . . . . . . . . . . . . . . . . 91

4.5. Diagramas: $\log \eta$ y $\log \eta$ ' de $\operatorname{los}$ brotes A y B . . . . . . . . . . . . . 94

4.6. Abundancias de oxígeno determinadas con los parámetros empíricos . . . . . 103 



\section{Capítulo 1}

\section{Generalidades}

Las Regiones H iı Gigantes (GHıIRs, sigla en inglés de Giant Hiı Regions) son objetos extendidos y luminosos, con luminosidades en la emisión de $\mathrm{H} \alpha$ de alrededor de $10^{40} \mathrm{erg} \mathrm{s}^{-1}$, observados en los discos de galaxias espirales, irregulares y galaxias enanas compactas azules (BCDs, sigla en inglés de Blue Compact Dwarfs). Las GHıRs se originan debido a la presencia de un gran número de estrellas jóvenes y masivas cuyo flujo ultravioleta ioniza el gas que las rodea y, por lo tanto, estas regiones indican una presencia de formación estelar violenta reciente o activa (Chu \& Kennicutt, 1994). Esto último se ha podido verificar para el caso de la GH iIR visible más cercana, 30 Doradus en la Nube Mayor de Magallanes (ver Figura 1.1), con espectroscopía del núcleo del cúmulo estelar, conocido como R136, realizada con el Telescopio Espacial Hubble (Massey \& Hunter, 1998). Tienen tamaños típicos de un centenar de parsecs de diámetro. Existen menciones en la literatura de tamaños de un orden de magnitud mayor, pero en general se refieren a regiones múltiples, las cuales pueden resolverse en varias componentes (Bosch et al., 2002). Las GH IIRs podrían ser clasificadas, de alguna manera, en una escala intermedia entre regiones de formación estelar de menor escala, como Orión en nuestra galaxia (ver Figura 1.2), y regiones con violentos procesos de formación estelar que ocurren en las galaxias con brotes estelares intensos (llamadas starburst en inglés) (Searle \& Sargent, 1972).

Estas regiones albergan cientos de estrellas masivas que, desde el punto de vista químico y morfológico, son parcialmente responsables de los cambios en la estructura de las galaxias a través de una constante emisión de masa a alta velocidad (vientos) o durante uno de los procesos energéticos más impresionantes del Universo como son las explosiones de supernovas. La gran cantidad de fotones ultravioleta emitida por las estrellas OB jóvenes y calientes junto con los de las estrellas menos masivas, con menor nivel de emisión pero muy numerosas, tiene como consecuencia que en muchas zonas de estas regiones el gas, principalmente hidrógeno, está altamente ionizado, con temperaturas típicas del orden de $10000 \mathrm{~K}$.

Junto a las zonas de gas caliente ionizado, las GH iIRs contienen gas en otros dos estados. Por un lado, se encuentra en un estado molecular frío y denso. En este estado el gas puede ser re-generado en zonas más densas que pueden formarse por la compresión en esas regiones dinámicamente complejas. Es en tales nubes moleculares frías que la actual formación estelar 


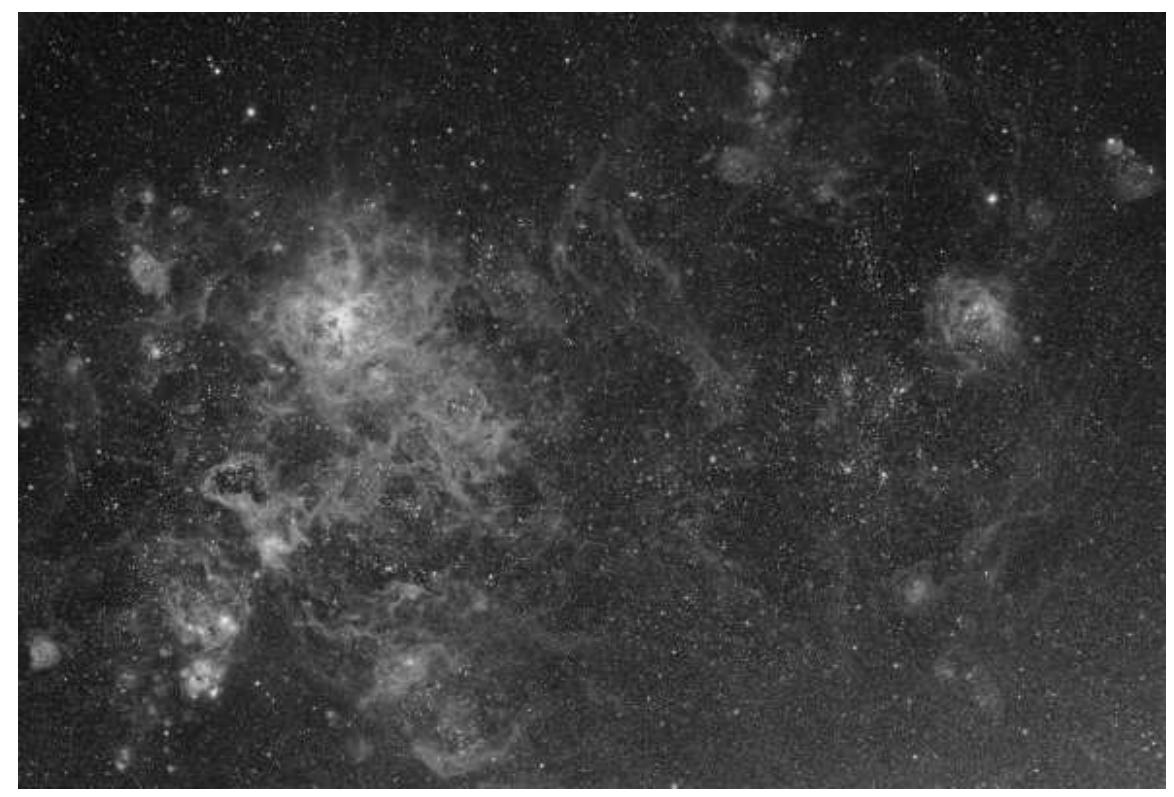

Figura 1.1: Imagen $\mathrm{H} \alpha$ de la Nebulosa Tarántula 30 Doradus, o NGC 2070. Imagen tomada con un telescopio refractor TEC-140 a f/7, en Hakos, Namibia, por Johannes Schedler PantherObservatory.

se está produciendo. Por otro lado, grandes volúmenes de gas caliente de baja densidad son producidos por la acción combinada de vientos y explosiones de SN que ocurren en la región. Un entorno tan complejo da lugar a más de un evento de formación estelar o a una nueva generación de estrellas. Uno de los principales propósitos para estudiar estas regiones radica en ampliar el conocimiento sobre la formación estelar dado que desde muchos aspectos astrofísicos es esencial para comprender desde la evolución de las galaxias, a través del enriquecimiento químico de las estrellas masivas, hasta la formación de los planetas, con el fin de entender las condiciones iniciales de los discos proto-planetarios. Es muy posible que la mayoría de las estrellas que se formaron alguna vez, y la mayoría de las que existen en la actualidad, lo hayan hecho en condiciones más similares a las de las Regiones Hir Gigantes o "starbursts", que a las condiciones más apacibles en las que se forman hoy en días las estrellas en nuestra vecindad galáctica.

En los últimos años ha habido grandes progresos para entender la formación estelar. Los modelos teóricos han tenido éxito en la reproducción de las principales características de las estrellas formadas en las nebulosas, tales como la función inicial de masa (IMF, sigla en inglés de Initial Mass Function). Los principales procesos físicos que pueden cambiar la masa final de las estrellas y que pueden establecer eficiencia en la formación estelar de las nebulosas son: la fragmentación durante el colapso, la acreción de masa, los vientos estelares y la radiación ultravioleta (Klessen, 2001; McKee \& Tan, 2003; Tilley \& Pudritz, 2005). Sin embargo, es muy complicado saber hasta qué punto estos procesos son capaces de modificar la función 


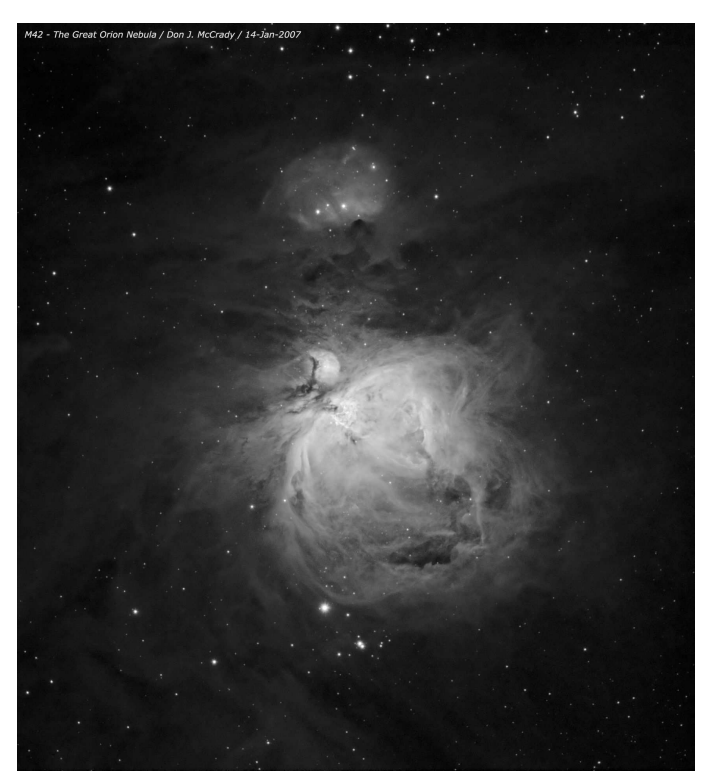

Figura 1.2: Imagen $\mathrm{H} \alpha$ de la Nebulosa (M42) de Orión. Imagen tomada con un telescopio refractor Takahashi Sky 90 a f/4.5, por Don McCrady

inicial de masa. En la actualidad, hay dos modelos principales que compiten para explicar el origen de la IMF: i) el modelo que plantea que la IMF estelar se origina en la distribución de masas de los núcleos densos de las nubes (CMF, sigla en inglés de core mass function) (Alves et al., 2007; Simpson et al., 2008). Bajo esta hipótesis, sólo se necesita explicar por qué la turbulencia en las nubes produciría una distribución de masas de los núcleos igual a la distribución de masas de las estrellas. Se han construido teorías para determinar la CMF a partir de la turbulencia en el medio interestelar (Padoan \& Nordlund, 2009; Hennebelle \& Chabrier, 2008), y se utilizan simulaciones hidrodinámicas para comprobar si se verifican las predicciones de las teorías (Smith et al.,2009aa, 2009bb). ii) El otro modelo alternativo del origen de la IMF es el de la "acreción competitiva" de Bate \& Bonnell (2003). En este modelo, las estrellas adquieren su masa compitiendo por el material disponible para ser acretado. En este caso la turbulencia es poco relevante para las masas finales de las estrellas, siendo sólo el mecanismo que originalmente fragmenta a la nube. Este modelo ha sido criticado por requerir, aparentemente, condiciones demasiado "restrictivas" para las estrellas en formación, y que posiblemente sólo puedan darse en la formación de cúmulos estelares muy poblados. Como se puede ver, hoy en día las discusiones siguen abiertas en este tema.

Por otro lado, el advenimiento de la generación de los grandes telescopios ha permitido estudiar y analizar las regiones de formación estelar no solo del Universo cercano, sino en galaxias distantes, como por ejemplo, las galaxias HiI que constituyen un potente indicador de distancia a escalas cosmológicas. Ya han sido identificadas numerosas galaxias Hir en los seguimientos realizados con el Sloan Digital Sky Survey (SDSS) (que en castellano significa 


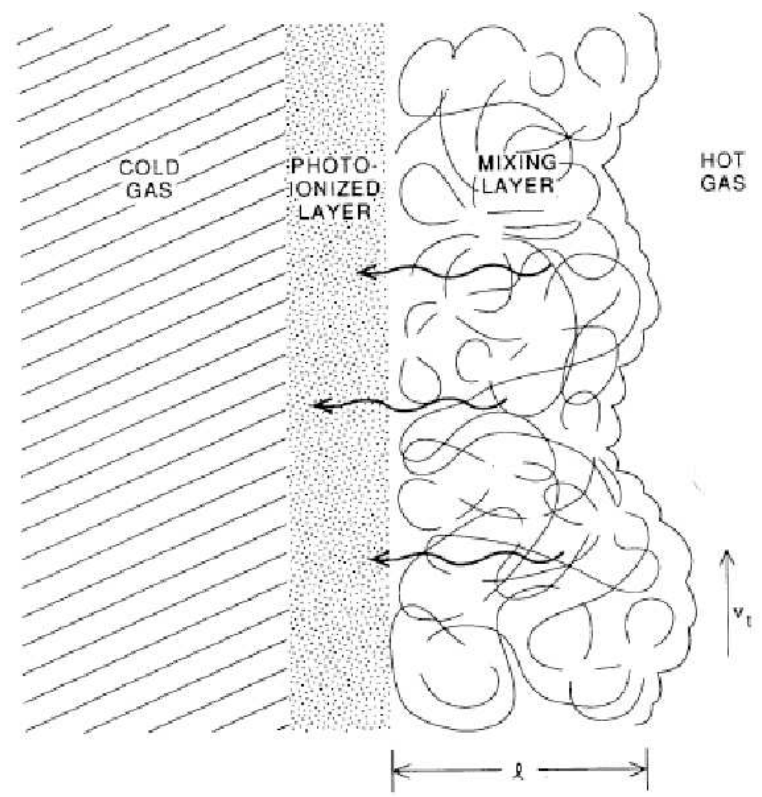

Figura 1.3: Dibujo esquemático que simula la geometría de las capas de mezcla turbulenta mostrando el gas frio y caliente y la capa fotoionizada lindera a la capa de mezcla. El gas caliente se mueve a una velocidad transversal $v_{t}$ relativa a la capa de mezcla (Slavin et al., 1993). La figura pertenece al mismo trabajo.

"Relevamiento Digital del Cielo Sloan").

Las galaxias Hı son galaxias con formación estelar violenta que producen una señal espectral fuerte e inconfundible la cual puede detectarse hasta $\mathrm{z} \sim 3$ (Lowenthal et al., 1997). Melnick, Terlevich \& Terlevich (2000) propusieron el uso de las galaxias Hit como una sonda cosmológica que resulta útil para medir la densidad de masa del Universo $\left(\Omega_{M}\right)$. Sin embargo este método que es potencialmente muy poderoso, se basa en la calibración del punto cero de la regresión observada en el plano fundamental para Regiones Hiı Gigantes Extragalácticas (su sigla en inglés es GEH IIRs).

\subsection{Características de las GH IIRs}

Smith \& Weedman (1970) encontraron que los anchos de los perfiles de las líneas de emisión de las GHırRs corresponden a velocidades supersónicas en el gas. Dicha fuente cinemática observada permanece aún sin una clara explicación, pero permite identificar y distinguir una región Hiı gigante de una mera aglomeración de regiones Hiı clásicas por medio de espectroscopía de alta resolución.

Melnick (1977) encontró una correlación estrecha entre la luminosidad de las GHıRs y la dispersión de velocidades observada en el perfil de las líneas de emisión. Diversas investigaciones siguieron a este descubrimiento y confirmaron la existencia de una correlación, 


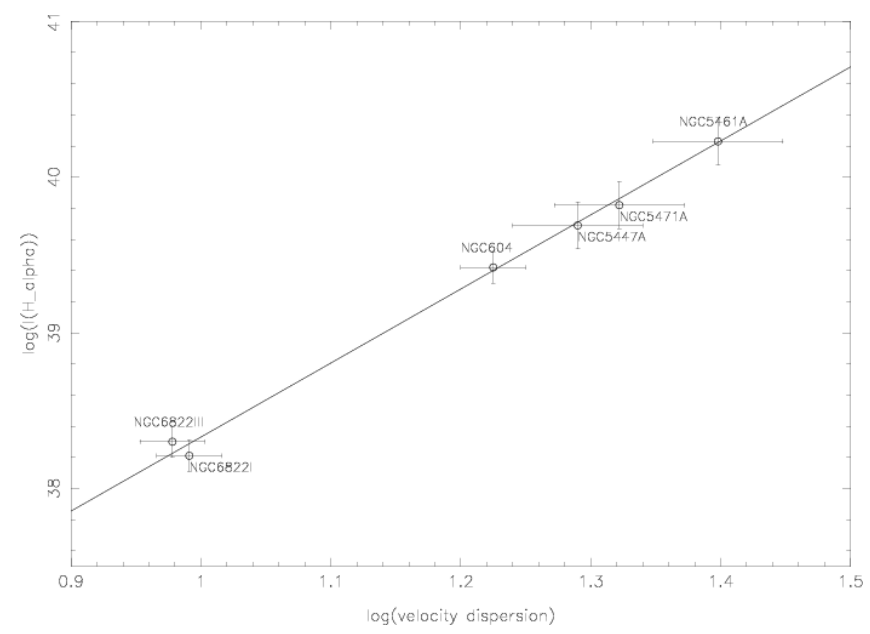

Figura 1.4: Regresión en el plano Luminosidad (L) vs. Dispersión de Velocidades $(\sigma)$ de Bosch et al. (2002). La figura pertenece al mismo trabajo.

aunque exhibían desacuerdos en las pendientes encontradas para dicha regresión (Terlevich \& Melnick, 1981; Roy et al., 1986; Bosch et al., 2002). Una gran variedad de mecanismos son los responsables del ensanchamiento que presentan los perfiles de las líneas de emisión en el espectro, lo que ha originado varías teorías paralelas para explicar dicho fenómeno, invocando dinámica de sistemas virializados (Tenorio-Tagle et al., 1993), superposición de múltiples burbujas de gas en expansión (Chu \& Kennicutt, 1994), o turbulencia del mismo gas interestelar (Medina Tanco et al., 1997). Bosch y colaboradores obtuvieron fotometría CCD de banda angosta en líneas de emisión para un grupo de GH IIRs, analizando cómo incidía la incerteza de los flujos publicados sobre las discrepancias de los valores hallados para la regresión en el plano Luminosidad (L) vs. Dispersión de Velocidades $(\sigma)$. Se halló una doble lectura, ya que los nuevos datos fotométricos no mejoraban la dispersión de los puntos en la regresión. Sin embargo, los autores realizaron un análisis más detallado de las regiones, considerando información sobre el estado evolutivo de algunas GH IIRs. Malumuth et al. (1996) y Drissen et al. (1993) analizaron la componente estelar de NGC 595, una de las GH irRs de la galaxia espiral M33, y encontraron signos de evolución. Con espectroscopía Fabry-Perot de alta resolución espacial y espectral de algunas regiones de M33 y M101, Muñoz Tuñón et al. (1995; 1996) resolvieron el perfil supersónico global observado en varias componentes discretas, algunas con anchos subsónicos. De acuerdo al modelo de evolución propuesto por Muñóz-Tuñón et al. (1996), cuando las burbujas de gas sopladas por estrellas masivas dentro de las regiones H II gigantes alcanzan el borde de la región, alteran el perfil global observado de la línea de recombinación del gas. Al descartar las regiones con evidentes signos de evolución, Bosch et al. (2002) obtuvieron una regresión muy estrecha en el plano L vs. $\sigma$, aunque basada en una muestra muy reducida (ver Figura 1.4). Si se desea estudiar la relación entre luminosidad y dispersión de velocidades en una muestra de GHirRs que tenga sentido estadístico es necesario 


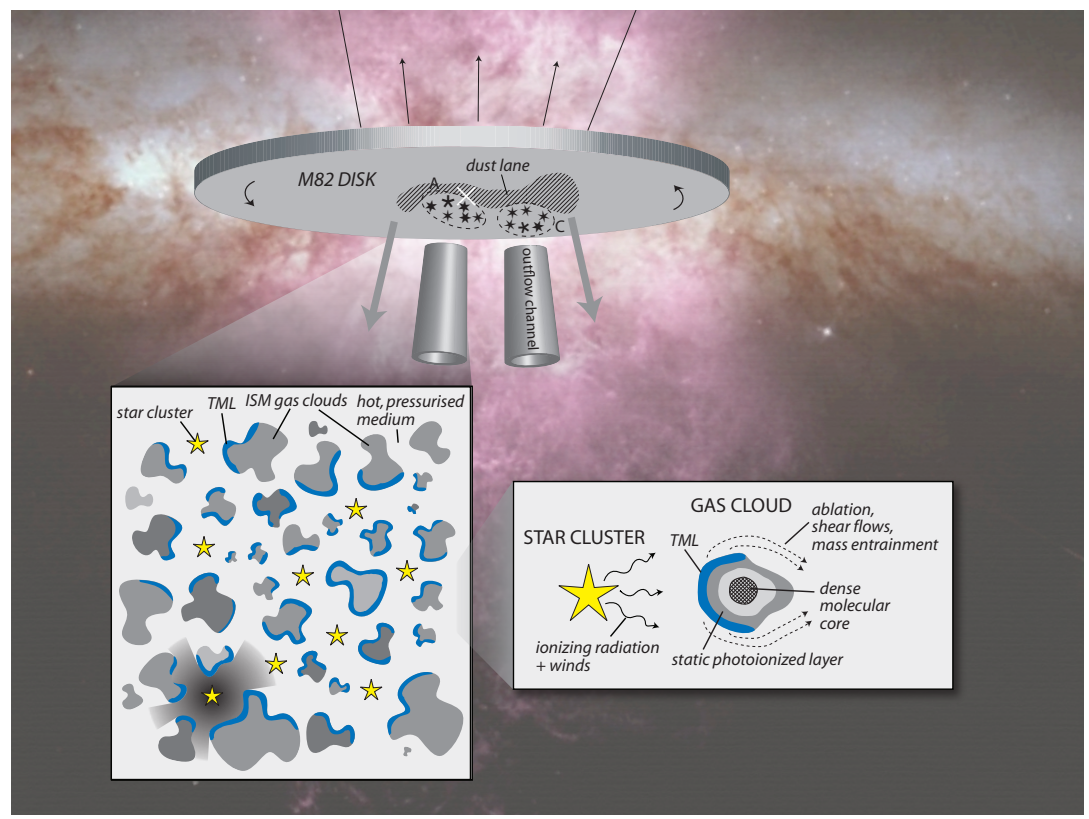

Figura 1.5: Dibujo esquemático que representa las ideas desarrolladas en el trabajo de Westmoquette et al., (2009) sobre el estado del ISM en la galaxia M82. El dibujo esquemático pertenece a dicho trabajo y la composición es de autoría de Linda Smith.

descubrir nuevas Regiones HiI Gigantes.

Varios estudios han tratado el hecho de que un perfil simple Gaussiano puede no ser suficientemente realista a la hora de ajustar las líneas de emisión observadas. Y en varios estudios se ha favorecido la presencia de una componente ancha omnipresente que podría estar explicando las alas del perfil integral (ver Figura 1.6) (Muñoz-Tuñón et al., 1996; Melnick et al., 1999; Díaz et al., 1987; Terlevich et al., 1996; Mendez \& Esteban, 1997; Homeier \& Gallagher, 1999; Hägele et al., 2007, 2009, 2010). Westmoquette et al., (2007a; 2007b) concluyen que la componente angosta representa el medio interestelar (ISM, sigla en inglés de Interestellar Medium) ionizado y perturbado, que surge a través de la convolución de los efectos de agitación del gas debido al brote de formación estelar y los movimientos gravitacionales del material virializado. Y por otro lado, la componente ancha resulta del campo de velocidad altamente turbulento asociado con la interacción de la fase caliente del ISM con nudos de gas más frío (ver Figura 1.3), lo que genera capas de mezcla turbulenta (ver Figura 1.5). Sin embargo, otros estudios han apoyado la existencia de perfiles tipo "shell" con dos alas, azul y roja, a ambos lados de la componente principal (Chu \& Kennicutt, 1994; Relaño \& Beckman, 2005; Rozas et al., 2006).

Para verificar la naturaleza gigante de estas regiones HiI es necesario realizar espectroscopía de alta resolución. La espectroscopía échelle proporciona un medio para buscar diferentes componentes cinemáticas en las líneas de emisión del gas y analizar estos efectos, ya que al- 


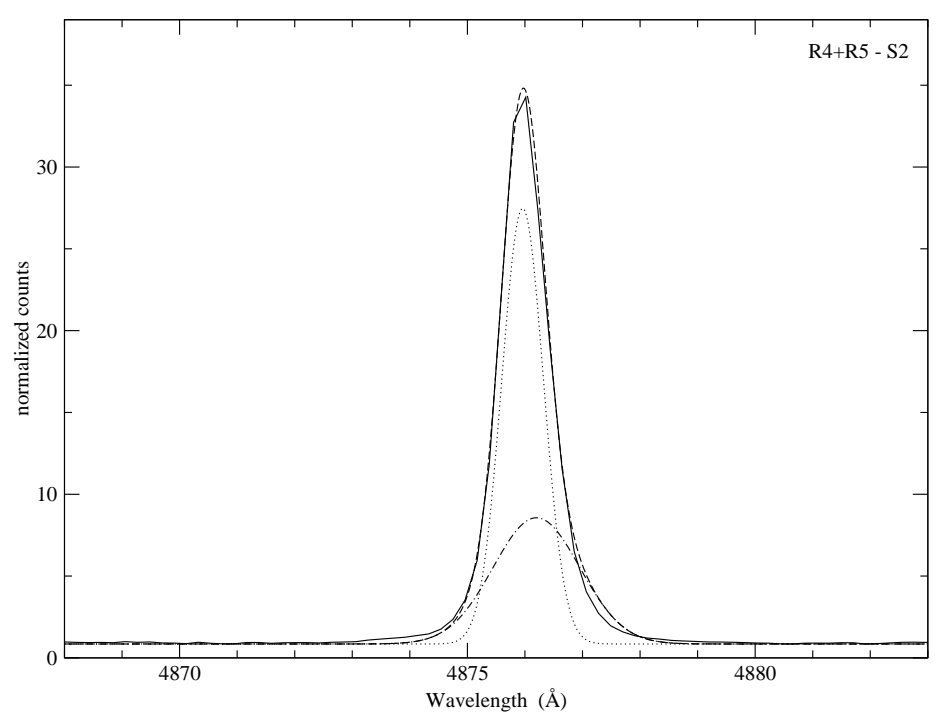

Figura 1.6: Ajuste de dos componentes en el perfil de emisión de $H \beta$ en una región HiI circunnuclear de la galaxia NGC 3310 (Hägele et al., 2010). La figura pertenece al mismo trabajo.

canza la resolución espectral necesaria tanto para resolver los anchos de los perfiles de las líneas de emisión como para determinar las dispersiones de velocidades intrínsecas del gas ionizado y verificar si estas son supersónicas $\left(>13 \mathrm{~km} \mathrm{~s}^{-1}\right)$.

La principal fuente de información sobre la metalicidad en todo tipo de objetos, desde los más cercanos hasta los más distantes, lo constituyen las regiones H II, desde las menos brillantes en el disco de la Galaxia, pasando por las GEH irRs hasta las galaxias HiI. Sus espectros presentan líneas de emisión brillantes las cuales son visibles en todas las regiones donde se hayan producido episodios de formación estelar recientes. El análisis de dichos espectros nebulares constituye el método más efectivo, a grandes distancias, para determinar las abundancias químicas de elementos tales como el helio, nitrógeno, oxígeno, neón, argón o azufre que dispongan de líneas de emisión en el rango óptico correspondientes a diferentes estados de ionización. El conocimiento detallado de estas abundancias resulta esencial para comprender la evolución del gas y de las estrellas, y esta información permite ampliar el conocimiento que se tiene acerca de la evolución química de las galaxias en el Universo Local. Con el advenimiento de los grandes telescopios, es posible disponer de datos para objetos menos brillantes y/o más lejanos, que acrecienta el conocimiento que se tiene del Universo más lejano y por tanto más joven. 


\subsection{Motivación y Objetivos}

Realizando una inspección en la lista de GH irRs conocidas a comienzos de los años 2000, habíamos encontrado que todas pertenecían al hemisferio norte, salvo 30 Doradus, en la Nube Mayor de Magallanes. Feinstein (1997) había estudiado la función de luminosidad de unas 10 galaxias del cielo austral, entre las cuales nosotros pudimos identificar al menos 40 regiones con luminosidades comparables a las de una GHIIR. Ocho de esas galaxias presentan regiones H II con brillos superiores a $10^{40} \mathrm{erg} \mathrm{s}^{-1}$, involucrando un total de 31 candidatos a RH IIG. Si se extiende la muestra a las regiones con luminosidades mayores a $10^{39} \mathrm{erg} \mathrm{s}^{-1}$, el número crece hasta unos 70 objetos. Para comenzar a hacer un estudio de GH IIRs con un sentido estadístico, esta muestra de regiones H II era ideal como puntapié inicial. Es así que de la muestra de Feinstein, seleccionamos las regiones más luminosas y estas pasaron a ser nuestros primeros candidatos a estudiar. En Firpo et al. (2005) obtuvimos datos de 4 candidatos, todas regiones H II muy luminosas, en las galaxias NGC 7552 y NGC 2997 utilizando el espectrógrafo Magellan Inamori Kyocera Echelle (MIKE) del Telescopio Magallanes, LCO. La alta relación señal-ruido sumada a la resolución del échelle nos permitió resolver el perfil de las líneas de emisión y calcular la dispersión de velocidades del gas ionizado. Esto se hizo midiendo el ancho observado del perfil, que luego fue corregido por ensanchamiento térmico, y por el ancho intrínseco del perfil instrumental, para obtener, así el ensanchamiento verdadero debido al comportamiento cinemático de la Región H iı. De ese análisis descubrimos la naturaleza gigante de tres de las cuatro regiones candidatas y pudimos confirmar que el mecanismo de excitación de las mismas se debía a fotoionización por estrellas. Además, encontramos que las regiones H iI gigantes descubiertas se ubican, dentro de las incertezas, en la regresión esperada para este tipo de objetos, en el plano L- $\sigma$. Uno de los principales resultados, presente en los datos publicados por Firpo et al. (2005) y del análisis de 5 regiones HiI observadas posteriormente, es que todas las Regiones HiI Gigantes de las galaxias de la muestra de Feinstein presentan signos de evolución química y es necesario observar regiones más jóvenes.

Entonces, con el objetivo de detectar regiones más jóvenes que permitan realizar un estudio comparativo de GHIIRs a distintas metalicidades y estados evolutivos, seleccionamos brotes de formación estelar intensa a partir de fotometría de líneas de emisión de galaxias más jóvenes, tales como las enanas compactas azules estudiadas por Cairós et al. (2001) y Gil de Paz et al. (2003). Detectamos que varios de los brotes observados en dichas galaxias presentan características de GHIIRs. De esta manera seleccionamos los brotes más brillantes en algunas galaxias de baja metalicidad, siendo estos los nuevos candidatos a estudiar.

Mediante espectroscopía échelle de alta resolución y espectroscopía de dispersión simple obtenidas en distintos telescopios del Observatorio de Las Campanas (Chile), estudiamos los brotes más brillantes en diversos objetos. La muestra incluye galaxias espirales de alta metalicidad como NGC 6070 (Figura 1.7), NGC 7479 (Figura 1.8) (Firpo et al., 2010) y la galaxia de baja metalicidad Haro 15 (Figura 1.9) del catálogo de Cairós et al. (2001) (Firpo 


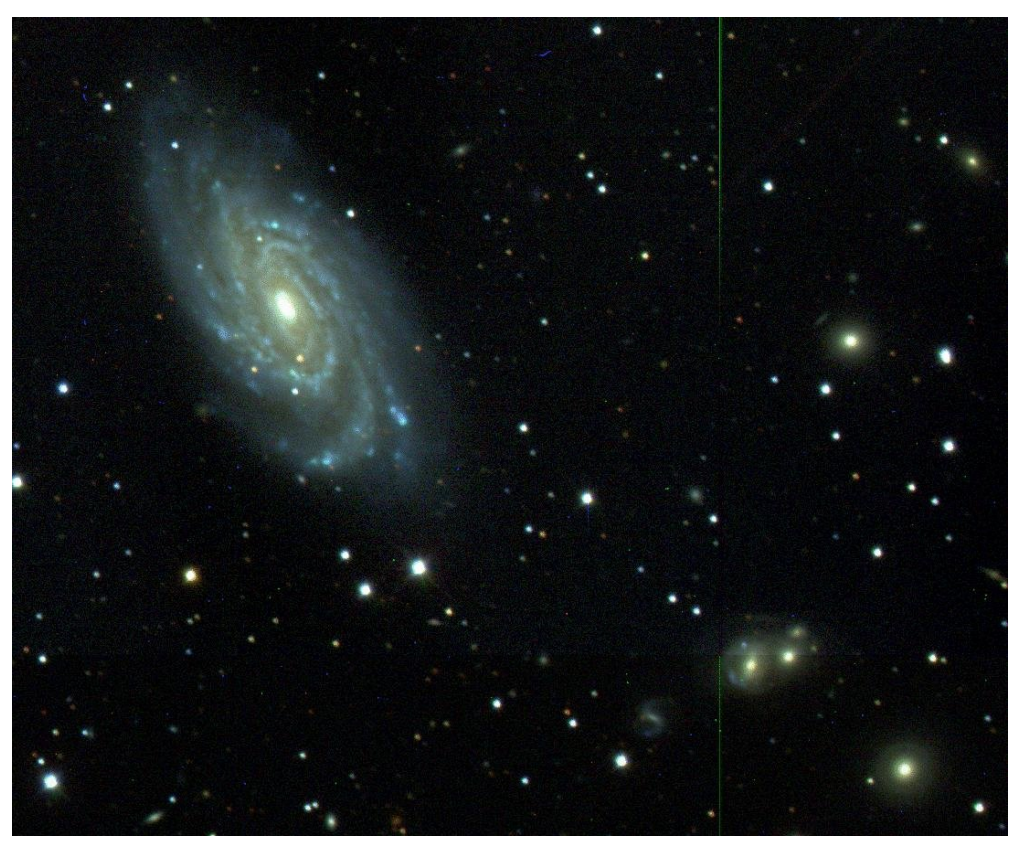

Figura 1.7: Galaxia NGC 6070. Esta fue la primer imagen (imagen de prueba) tomada por el Sloan Digital Sky Survey el 10 de junio de 1998.

et al., 2011).

A partir del ajuste de un perfil simple Gaussiano a las líneas de emisión, observamos un residuo presente en las alas de los perfiles en varias líneas de emisión, evidente en la línea $\mathrm{H} \alpha$ y que se confirma en otras líneas de emisión. Para determinar el número óptimo de componentes Gaussianas y ajustar cada perfil de línea, y con el fin de minimizar las incertezas en la dispersión de velocidades del gas ionizado, consideramos la información proporcionada en la literatura a partir de la gran variedad de estudios propuestos para interpretar la existencia del ensanchamiento en las líneas de emisión. Además de la componente relativamente angosta y siempre que fue posible, evaluamos la eventual presencia de una componente ancha supersónica medida en el perfil de la línea de emisión de la GHIIR, o la presencia de dos componentes simétricas de baja intensidad en el ajuste de los anchos de los perfiles de línea de emisión observados.

En esta Tesis, confirmando lo ya mencionado en la literatura, presento evidencia de la existencia de diferentes componentes cinemáticas en las líneas de emisión del gas. Además, en algunas regiones pudimos detectar la presencia de más de una sub-componente angosta, cuyas velocidades radiales relativas no pueden explicarse mediante fluctuaciones en la rotación del disco galáctico (Firpo et al., 2010, 2011).

Para avanzar en el análisis de las propiedades físicas de este tipo de objetos y en las diferentes componentes encontradas, debemos poder determinar temperaturas, densidades y abundancias químicas del gas. El análisis de dichos parámetros físicos puede llevarse adelante 


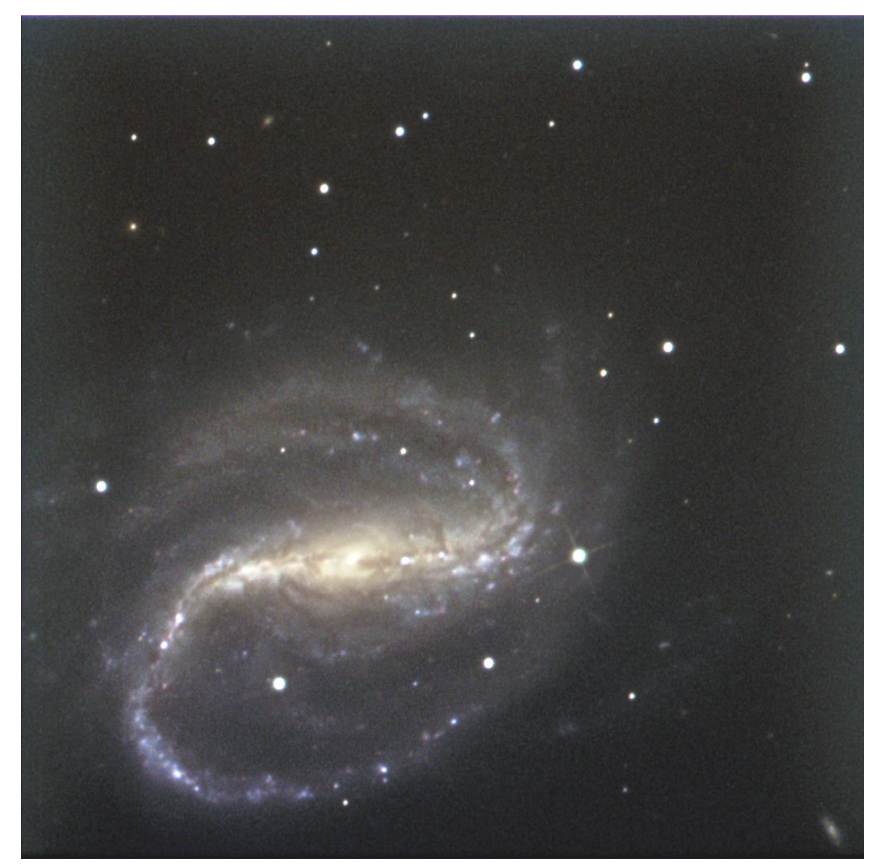

Figura 1.8: Galaxia NGC 7479. Tomada por Nik Szymanek y obtenida con el Telescopio Faulkes Norte, Maui, copyright FTLLC

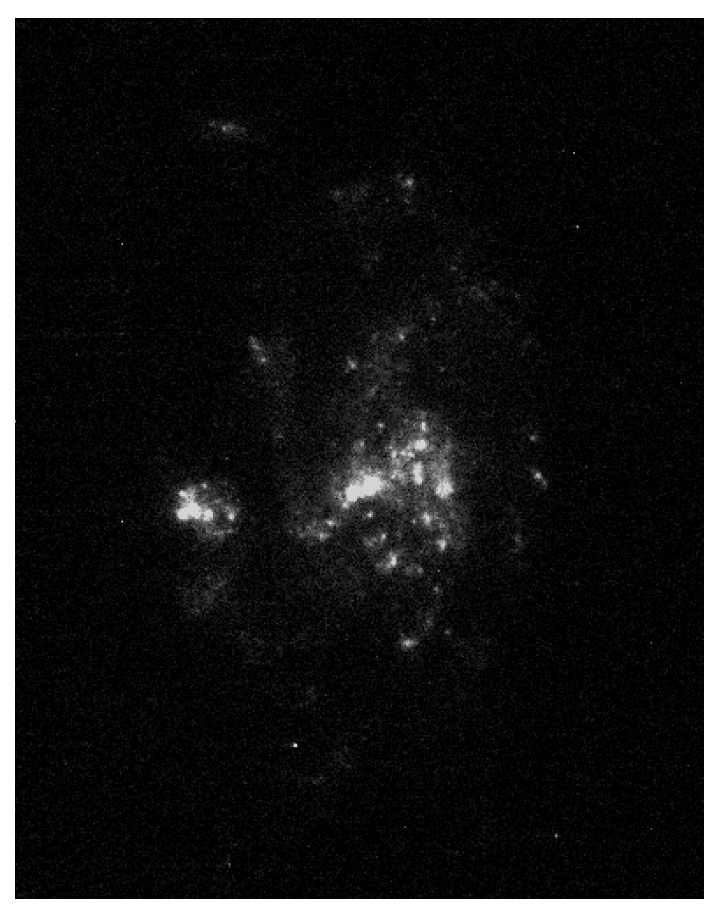

Figura 1.9: Galaxia Haro 15. Imagen $\mathrm{H} \alpha$ tomada con la cámara Wide Field Planetary Camera 2, obtenida del Multimission Archive del Space Telescope Science Institute (MAST). 
mediante el estudio de las intensidades relativas de las líneas de emisión del gas. Para ello necesitamos también una amplia cobertura espectral. La calidad única de nuestros datos permitió realizar un análisis detallado de las características del gas ionizado discriminado para cada componente y para el flujo global de las líneas. Para llevar esto a cabo, se ha aplicado el método propuesto por el Grupo de de Astrofísica del Departamento de Física Teórica de la Universidad Autónoma de Madrid, España, para la determinación de los parámetros físicos y abundancias.

En esta Tesis presento resultados sobre la estimación de temperaturas, densidades y abundancias químicas discriminadas por las diferentes componentes cinemáticas del gas. 



\title{
Regiones HII Gigantes en NGC 7479 \& NGC 6070
}

\author{
Giant HII Regions in NGC7479 8 NGC6070
}

Firpo, V., Bosch, G., Hägele, G. F., and Morrell, N., 2010, MNRAS 406, 1094

\subsection{Resumen de la publicación}

En este Capítulo se presentan nuevos resultados de la búsqueda de Regiones H ir Gigantes en dos galaxias visibles desde el hemisferio sur: NGC 7479 y NGC 6070. Usando espectros de alta resolución, obtenidos con diferentes instrumentos del Observatorio Las Campanas, Chile, se han podido resolver los anchos de los perfiles de las líneas de emisión y determinar la dispersión de velocidades intrínseca del gas ionizado. Se ha detectado que los anchos de los perfiles de emisión corresponden a dispersiones de velocidades supersónicas en las seis regiones H ir observadas. Se ha encontrado que todos ellos muestran, al menos, dos componentes cinemáticas diferentes: una componente relativamente angosta (entre 11 y $22 \mathrm{~km} \mathrm{~s}^{-1}$ ) y otra componente más ancha (entre 31 y $77 \mathrm{kms}^{-1}$ ). Dos de las regiones estudiadas muestran un perfil complejo en las líneas de emisión angostas de los diferentes iones, el cual pudo ser dividida en dos componentes con distintas velocidades radiales. Mientras tanto, el ensanchamiento de las alas del perfil global pudo ser ajustado con una componente ancha en casi todos los perfiles de las líneas de emisión observadas. En una región este residuo pudo ser reproducido como perfiles tipo "shell" (cáscaras) en expansión debido a la presencia de dos componentes separadas a ambos lados de las componentes principales. Además, se ha analizado el impacto que tiene la presencia de varias componentes sobre la ubicación de la región H iI en el plano $\log (L)-\log (\sigma)$. Aunque la distribución global confirma la presencia de una regresión, la ubicación precisa de las regiones en el plano depende fuertemente de las propiedades de las componentes derivadas en el ajuste del perfil de emisión. 


\subsection{Fundamentos básicos}

Con el fin de verificar la naturaleza de nuestras regiones candidatas a Regiones Hir Gigantes se obtuvieron espectros de alta resolución para poder medir los anchos en los perfiles de las líneas de emisión y así estimar si la dispersión de velocidades es, en efecto, supersónica. Para determinar el número óptimo de componentes Gaussianas que mejor se ajusta a cada perfil de línea, y con el fin de minimizar las incertezas en la dispersión de velocidades del gas ionizado, se ha considerado la información disponible en la literatura. Algunos trabajos previos han tratado el hecho de que un perfil simple Gaussiano puede no ser suficientemente realista a la hora de ajustar las líneas de emisión observadas. Varios estudios han favorecido la presencia de una componente ancha omnipresente que podría estar explicando las alas del perfil integral (Muñoz-Tuñón et al., 1996; Melnick et al., 1999; Díaz et al., 1987; Terlevich et al., 1996; Mendez \& Esteban, 1997; Homeier \& Gallagher, 1999; Hägele et al., 2007, 2009, 2010, entre otros). En cambio, otros estudios han apoyado la existencia de perfiles tipo shell con dos alas, azul y roja, a ambos lados de la componente principal (Chu \& Kennicutt, 1994; Relaño \& Beckman, 2005; Rozas et al., 2006).

En este trabajo se presentan los datos échelle obtenidos en el Observatorio Las Campanas (LCO) de seis regiones candidatas a GHIIRs en las dos galaxias mencionadas. Se ha determinado la dispersión de velocidades y evaluado la posible presencia de una componente ancha o dos componentes simétricas a ambos lados de las componentes angostas en el ajuste de los anchos de los perfiles de líneas de emisión observados. En la publicación a continuación se presentan las observaciones y la reducción de los datos en la Sección OBSERvaTions AND Reductions; en la Sección Analysis of line profiles los detalles del análisis realizado sobre los perfiles de las líneas de emisión y se analiza cada caso individualmente; en la Sección Relation between H $\alpha$ Luminosities and Velocity Dispersion se analiza el impacto que tiene la presencia de varias componentes sobre la ubicación de la región H i en el plano $\log (L)-\log (\sigma)$; por último se incluye un resumen y las conclusiones del trabajo en la Sección nombrada como Summary AND CONCLUSIONs.

\subsection{Herramientas utilizadas}

De acuerdo a la denominación canónica de GHirRs, los candidatos han sido nombrados siguiendo el rango de brillo publicado en el catálogo de Feinstein (1997). La alta resolución espectral se obtuvo con el espectrógrafo échelle del telescopio de 100" du Pont, del Observatorio Las Campanas (LCO), observados en 2006. El rango espectral abarcó desde 3800 hasta 9500 Å. Las condiciones de observación fueron buenas con un seeing de un segundo de arco. Con el fin de minimizar la contribución del ruido en la lectura del espectro final, se aplicó un binning $2 \times 2$ al CCD. La resolución espectral alcanzada en los espectros échelle (obtenido con una ranura de 1 segundo de arco de ancho) es de $\mathrm{R} \simeq 25000: \Delta \lambda=0.25 \AA$ a los $\lambda 6000 \AA$, medida 
a partir del ancho a potencia mitad (FWHM) de las líneas de la lámpara de comparación de Thorio-Argón. Esto se traduce en una resolución en velocidad radial de $\sim 12 \mathrm{~km} \mathrm{~s}^{-1}$.

Durantes las noches de observación se tomaron espectros de estrellas estándares, HR 7950, HR 4468, y una estándar espectrofotométrica de CALSPEC, Feige 110, con el propósito de calibrar en flujo los espectros. Además, se tomaron todas las noches espectros de comparación de Th-Ar, milky flats (flats de cielo obtenidos con un difusor durante la tarde), y bias. El tiempo de exposición para las estrellas estándares fue de cinco segundos para las estrellas brillantes HR 7950 y HR 4468, y 1200 segundos para Feige 110.

También se han obtenido espectros de alta resolución para las tres regiones Hir de la galaxia NGC 6070 utilizando el espectrógrafo échelle doble, Magellan Inamori Kyocera Echelle (MIKE) del Telescopio de 6.5-m, Magellan II (Clay), de LCO, en julio de 2004. No se aplicó ningún binning al $\mathrm{CCD}$ de $2 \mathrm{~K} \times 4 \mathrm{~K}$ y la ranura utilizada fue de 1 segundo de arco. La resolución espectral medida en los espectros de MIKE es de $11 \mathrm{kms}^{-1}$, muy similar a la obtenida en los espectros de du Pont. El tiempo de exposición para la estrella estándar espectrofotométrica, BD+28D4211, fue de 900 segundos. También se tomaron lámparas de comparación de Th-Ar, milky flats y bias para calibrar los datos.

El análisis de los datos se realizó con el software $\operatorname{IRAF}^{1}$. Luego de la resta de bias y correcciones por flat fields con los Milky Flats, las imágenes bidimensionales fueron corregidas por rayos cósmicos con la tarea cosmicrays de IRAF, la cual detecta y elimina los rayos cósmicos con un algoritmo de cociente de flujos. Los datos corregidos se redujeron con las rutinas de IRAF siguiendo el mismo procedimiento descripto en Firpo et al., (2005).

\subsection{Metodología en la cinemática}

Para determinar las velocidades radiales y las dispersiones de velocidades del gas ionizado, se ha medido la longitud de onda central y el ancho en varias líneas de emisión intensas. La velocidad radial de cada línea de emisión se ha obtenido de su longitud de onda central determinada ajustando el perfil Gaussiano, y sus errores han sido proporcionados por el error obtenido en el ajuste realizado con la tarea ngaussfit de IRAF y teniendo en cuenta el error medio cuadrático de la calibración en longitud de onda. La dispersión de velocidades intrínseca $\left(\sigma_{\text {int }}\right)$ de cada línea de emisión ha sido calculada como se describe en Firpo et al., (2005) y detallada aquí en la Sección 2.5, donde se explica que la dispersión de velocidades intrínseca $\left(\sigma_{\text {int }}\right)$ es corregida por las contribuciones instrumental y térmica de cada línea de emisión.

Para ajustar las múltiples componentes en los perfiles observados se utilizó la tarea ngaussfit de IRAF. Esta tarea realiza un ajuste Gaussiano iterativo para varios perfiles de líneas espectrales. La tarea permite seleccionar distintos parámetros a ser ajustados y ofrece una estimación de la incerteza de los parámetros derivados. La tarea necesita valores

\footnotetext{
${ }^{1}$ Image Reduction and Analysis Facility, distribuido por NOAO, operado por AURA, Inc., bajo contrato con NSF.
} 
iniciales de los coeficientes, los cuales pueden ser especificados a través de tablas generadas previamente.

En los casos en que más de una componente se hace evidente, hemos seguido un procedimiento iterativo en el que sólo se le permite a la tarea ajustar un subconjunto limitado de parámetros a la vez. Esto se hace para limitar el universo de posibles soluciones en el ajuste, y haciendo uso de la información disponible en cada línea de emisión. Luego de obtener una estimación inicial de los parámetros de la segunda componente, son fijados la amplitud, el centro y el ancho de cada componente, dejando los parámetros de la otra componente sin tocar. Una vez que la longitud de onda central de cada componente se conoce relativamente bien, se establece ésta como parámetro fijo y se permite que la tarea realice un ajuste final sobre la amplitud y el ancho en todas las componentes y al mismo momento.

En todos los casos los ajustes de los perfiles han demostrado la presencia de un residuo en las alas de las emisiones, bien evidente en la línea intensa $\mathrm{H} \alpha$. Por lo tanto, se ha evaluado la existencia de una componente ancha o dos componentes tipo shell en el perfil de la línea. En la primera hipótesis, se ha introducido una componente con una anchura inicial que es tres veces el ancho de la componente angosta (Hägele et al., 2007). Se ajustaron las posiciones de los picos para las componentes angostas y, a continuación, los anchos de los perfiles. Los parámetros de las componentes anchas fueron dados luego, antes de iniciar el procedimiento iterativo nuevamente. En el segundo escenario, el ajuste del residuo presente en las alas del perfil, fue realizado siguiendo un procedimiento iterativo similar, pero en este caso se añade una componente angosta corrida al azul y una componente angosta corrida hacia el rojo. La validación de la multiplicidad en el perfil y el ensanchamiento es controlado sobre las diferentes líneas de emisión para cada región, aunque el análisis más confiable proviene del perfil de las líneas más intensas, como la línea de recombinación $\mathrm{H} \alpha$.

De la muestra de seis GHirRs se ha encontrado que todas ellas muestran evidencia de un residuo presente en los perfiles de las líneas de emisión. Sólo en una de las regiones, donde no pudo ser ajustada una componente ancha, se han ajustado dos componentes angostas simétricas separadas en velocidad respecto a las componentes principales; en el resto de las regiones el ajuste de una componente ancha dio resultados satisfactorios. En la publicación se discuten los resultados agrupándolos según los tipos de resultados de los perfiles y por región.

\subsection{Dispersión de velocidades}

El parámetro físico que se desea medir es la dispersión de velocidades intrínseca del gas ionizado $\left(\sigma_{\text {int }}\right)$. Sin embargo, el ancho del perfil observado $\left(\sigma_{o}\right)$ está afectado por la contribución del movimiento térmico aleatorio $\left(\sigma_{t}\right)$ y del perfil instrumental $\left(\sigma_{i}\right)$ dado por el espectrógrafo. Por lo tanto, dispersión de velocidades verdadera estará dada por:

$$
\sigma_{i n t}^{2}=\sigma_{o}^{2}-\sigma_{i}^{2}-\sigma_{t}^{2}
$$


suponiendo que las regiones observadas tienen una temperatura cinética típica $T=10^{4} \mathrm{~K}$ y que el perfil instrumental $\left(\sigma_{i}\right)$ se puede determinar a partir del ajuste Gaussiano de las líneas de emisión angostas de la lámpara de Th-Ar. Los errores en la determinación de la dispersión de velocidades son calculados utilizando los errores de observación en el perfil observado $\sigma_{o}$ y considerando errores insignificantes en $\sigma_{i}$ y $\sigma_{t}$. Debido a la alta metalicidad de las regiones Hiı en galaxias espirales, las temperaturas son probablemente inferiores a $10^{4} \mathrm{~K}$ (Díaz et al., 2007). En estas regiones también se ha hecho la suposición del caso más extremo donde la temperatura electrónica sea de unos $5000 \mathrm{~K}$, para analizar como afecta este cambio de temperatura a la contribución de la dispersión de velocidades, pero los resultados no arrojaron grandes diferencias respecto de suponer $\mathrm{T}=10^{4} \mathrm{~K}$. Para una temperatura cinética de $\mathrm{T}=10^{4} \mathrm{~K}$, la velocidad del sonido es de unos $13 \mathrm{~km} \mathrm{~s}^{-1}$. Se dice que la dispersión de velocidades es supersónica cuando es mayor o igual a ese valor. En este caso se está frente a una GHırR. Valores menores, corresponden a regiones Hiı clásicas. 



\title{
Giant H II regions in NGC 7479 and NGC 6070
}

\author{
V. Firpo, ${ }^{1 \star}$ G. Bosch,${ }^{1} \dagger$ G. F. Hägele ${ }^{1,2}$ and N. Morrell ${ }^{3}$ \\ ${ }^{1}$ Facultad de Ciencias Astronómicas y Geofísicas, Universidad Nacional de la La Plata, Paseo del Bosque s/n, 1900 La Plata, Argentina \\ ${ }^{2}$ Departamento de Física Teórica, C-XI, Univerdidad Autónoma de Madrid, 28049 Madrid, Spain \\ ${ }^{3}$ Las Campanas Observatory, Carnegie Observatories, Casilla 601, La Serena, Chile
}

Accepted 2010 March 23. Received 2010 March 15; in original form 2009 October 14

\begin{abstract}
We present new results from our search for giant $\mathrm{H}_{\text {II }}$ regions in galaxies visible from the Southern hemisphere. In this work we study two galaxies: NGC 7479 and NGC 6070. Using high-resolution spectra, obtained with different instruments at Las Campanas Observatory, we are able to resolve the emission-line profile widths and determine the intrinsic velocity dispersion of the ionized gas. We detect profile widths corresponding to supersonic velocity dispersions in the six observed $\mathrm{H}$ II regions. We find that all of them show at least two distinct kinematical components: a relatively narrow feature (between 11 and $22 \mathrm{~km} \mathrm{~s}^{-1}$ ) and a broader (between 31 and $77 \mathrm{~km} \mathrm{~s}^{-1}$ ) component. Two of the regions show a complex narrow profile in all ion lines, which can be further split into two components with different radial velocities. Whereas the wing broadening of the overall profile can be fitted with a low-intensity broad component for almost all profiles, in one region it was better reproduced by two separate shell-like wings. We have analysed the impact that the presence of multiple components has on the location of the $\mathrm{H}$ II regions in the $\log (L)-\log (\sigma)$ plane. Although the overall distribution confirms the presence of a regression, the precise location of the regions in the plane is strongly dependent on the components derived from the profile fitting.
\end{abstract}

Key words: H II regions - galaxies: individual: NGC 7479 - galaxies: individual: NGC 6070 galaxies: starburst.

\section{INTRODUCTION}

The most extended and luminous objects which are observed on the discs of spirals, in irregulars and in starburst galaxies are called giant extragalactic $\mathrm{H}$ II regions (GH IIRs). $\mathrm{GH}$ IIRs are places of very active star formation and they are characterized by the large emission of ultraviolet photons from a large number of young and massive stars. Owing to the large number of ionizing photons most of the surrounding gas is ionized, and the recombination process provides a strong signature of recent or ongoing massive star formation.

The emission-line profile widths of the giant $\mathrm{H}$ II regions imply the existence of supersonic motions in the gas (Smith \& Weedman 1970). Furthermore, Terlevich \& Melnick (1981) found a correlation between the gas velocity dispersion $(\sigma)$ and the total luminosity $(L)$ emitted in the respective line. Hippelein (1986) and Arsenault \& Roy (1988) confirmed the existence of such a regression, but there was no agreement on the values derived for its slope so no conclusion could be reached regarding the origins of this motion. FuentesMasip et al. (2000) and Bosch, Terlevich \& Terlevich (2002) using different techniques on different samples agreed on a slope close

${ }^{\star}$ E-mail: vfirpo@fcaglp.unlp.edu.ar

†IALP-CONICET, Argentina. to a value of 4 , which seemed to favour the gravitational source of energy for the observed supersonic motion. Even if the nature of this behaviour is not fully understood, it still allows us to distinguish giant $\mathrm{H}_{\text {II }}$ regions from an agglomeration of classical $\mathrm{H}_{\text {II }}$ regions by means of high-resolution spectroscopy. GH IIRs provide the link between small-scale star-forming regions, such as Orion in our Galaxy and violent star formation processes taking place in starburst galaxies.

In Firpo, Bosch \& Morrell (2005) we have confirmed the giant nature of three candidates to giant $\mathrm{H}$ II regions in the southern sky which were identified as very luminous $\mathrm{H}$ II regions by Feinstein (1997).

Here we continue our search and detailed analysis of GH IIRs in local Universe galaxies. We have selected from the Feinstein catalogue, a sample of the brightest $\mathrm{H}$ II regions from two spiral galaxies: NGC 7479 and NGC 6070.

NGC 7479 is a barred spiral galaxy, at a distance of $31.92 \mathrm{Mpc}$ (Rozas et al. 1999), classified as SB(s)c by de Vaucouleurs et al. (1991). Devereux (1989) and Martinet \& Friedli (1997) have classified it also as a starburst galaxy, whereas Keel (1983) and Ho, Filippenko \& Sargent (1997) have identified it as a low-ionization nuclear emission-line region (LINER) and a Seyfert 1.9 galaxy, respectively. Many studies have been performed on this galaxy owing to the presence of a certain asymmetry in the spiral structure 
(Quillen et al. 1995) that leads several authors to suggest this might be owed to a recent merger event (Laine 1996; Laine \& Heller 1999). This scenario can also account for perturbations in the velocity field (Laine \& Gottesman 1998) and the latest minor merger model indicates that the remnant may be situated within the bar (Laine 2001) as no remnant of the merger could be identified in optical images (Saraiva \& Benedict 2003).

NGC 6070, at a distance of $29.8 \mathrm{Mpc}$ (García-Gómez, Athanassoula \& Barberà 2002), is classified as SA(s)cd by de Vaucouleurs et al. (1991) although Grosbøl, Patsis \& Pompei (2004) state that a bar with two main arms can be identified. Pohlen \& Trujillo (2006) further studied the bar structure classifying it as Type II.o.CT according to Erwin, Pohlen \& Beckman (2008). The galaxy shows a normal arm distribution, with two arms that break into several on each side of the central region (see Fig. 2). The disc dynamics was studied by Márquez et al. (2002), and García-Gómez et al. (2002) studied the distribution of H II regions in the galaxy.

In order to verify the nature of our giant $\mathrm{H}_{\text {II }}$ region candidates, we obtained high-resolution spectra to measure the emission-line profile widths and to estimate if the velocity dispersion is indeed supersonic. To determine the optimum number of Gaussian components to fit each line profile in order to minimize the uncertainty in the velocity dispersion of the ionized gas, we have considered information from other studies available in the literature. Previous papers have dealt with the fact that a single Gaussian profile might not be realistic enough when fitting the observed emission lines. Several studies favour the presence of an omnipresent broad component which explains the integral profile wings. They include Melnick, Tenorio-Tagle \& Terlevich (1999) who identified a broad component in the recombination lines in the central region of the 30 Doradus nebula, Díaz et al. (1987) and Terlevich et al. (1996) in the M33 giant H II region NGC 604, Mendez \& Esteban (1997) in four Wolf-Rayet galaxies and Homeier \& Gallagher (1999) in the starburst galaxy NGC 7673. More recently, Hägele et al. (2007, 2009, 2010) and Hägele (2008) found that the best Gaussian fits in circumnuclear star-forming regions involved the presence of broad and narrow components for the emission lines of the ionized gas.

A variety of line broadening mechanisms have been proposed to interpret the existence of the broad supersonic component measured in the emission-line profile of GH IIRs. Dynamics of virialized systems (Tenorio-Tagle, Muñoz-Tuñón \& Cox 1993), superposition of multiple gas bubbles in expansion (Chu \& Kennicutt 1994) or turbulence of the same interstellar gas (Medina Tanco et al. 1997). More recently, Westmoquette et al. (2007a,b) concluded that the narrow component represents the general disturbed ionized interstellar medium (ISM), arising through a convolution of the stirring effects of the starburst and gravitational virial motions. On the other hand, the broad component results from the highly turbulent velocity field associated with the interaction of the hot phase of the ISM with cooler gas knots, setting up turbulent mixing layers.

Other studies support the existence of shell-like profiles on the blue and red wings of the main feature as found by Chu \& Kennicutt (1994), who state that the integrated line profiles of the entire 30 Dor region may be fitted with a broad Gaussian with low-intensity wings. Relaño \& Beckman (2005) claim that a large fraction of the $\mathrm{H}$ II regions in three barred spiral galaxies shows high-velocity and low-intensity features in its integrated line profiles and Rozas et al. (2006) find that the great majority of their sampled $\mathrm{H}$ II regions show that the brightest principal component is accompanied by low-intensity components symmetrically shifted in velocity.

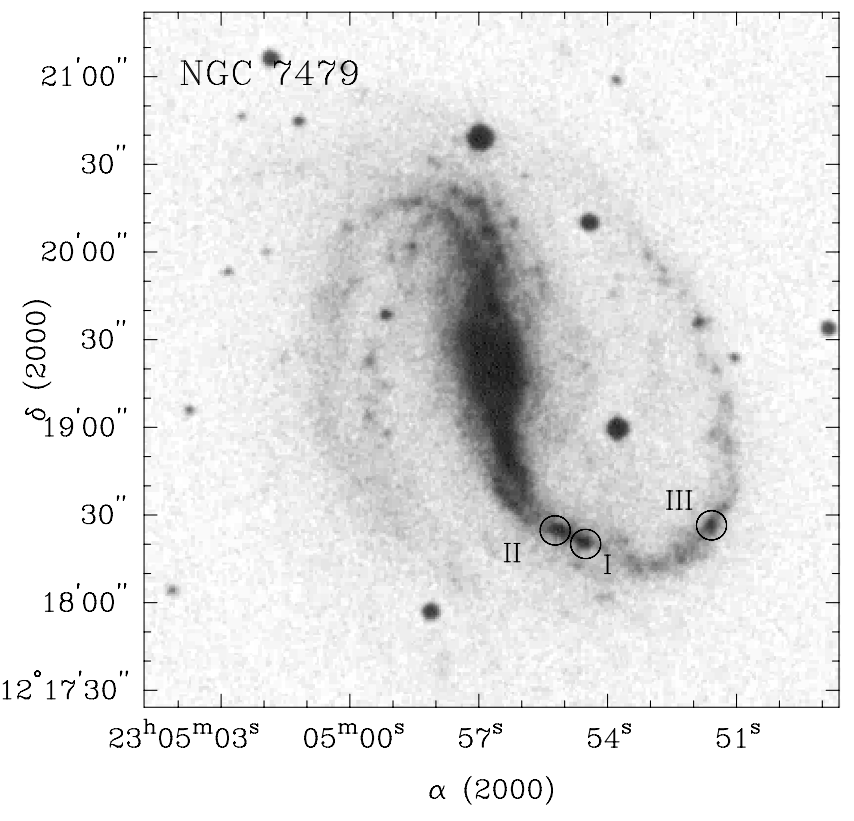

Figure 1. $\mathrm{H} \alpha$ image with the GH ${ }_{\mathrm{IIR}}$ candidates observed in NGC 7479, identified by circles. $\mathrm{H} \alpha$ images were kindly made available by $\mathrm{C}$. Feinstein.

In this paper we present echelle data obtained at Las Campanas Observatory (LCO) of six GH IIRs candidates in the two mentioned galaxies. We have determined the velocity dispersion and we have evaluated the possible presence of a broad component or two symmetric low-intensity components in the fit with the observed emission-line profile widths. In Section 2 we present the observations and the data reduction. Section 3 details the analysis performed on the emission-line profiles and discusses each conspicuous case individually. The summary and conclusions of this work are included in Section 4.

\section{OBSERVATIONS AND REDUCTIONS}

According to canonical denomination for GH IIRs we have labelled our candidates following their brightness ranking from $\mathrm{Fe}$ instein catalogue. NGC7479 I is therefore the brightest region in NGC 7479, NGC 7479 II is the second brightest and so on. Observed regions from NGC 7479 and NGC 6070 are shown in Figs 1 and 2, respectively. High-resolution spectra were obtained with an echelle spectrograph at the 100 -inch du Pont Telescope, LCO, between 2006 July 19 and 22. The spectral range covered by the observations was from 3800 to $9500 \AA$. Observing conditions were good with 1 arcsec seeing and photometric sky. A $2 \times 2$ binning was applied to the CCD in order to minimize readout contribution to the final spectrum noise. The spectral resolution achieved in our du Pont Echelle data (obtained with 1 arcsec effective slit width) is $R \simeq 25000: \Delta \lambda=0.25 \AA$ at $\lambda 6000 \AA$, as measured from the full width at half-maximum (FWHM) of the Th-Ar comparison lines. This translates in a resolution of $\sim 12 \mathrm{~km} \mathrm{~s}^{-1}$.

The standard stars, HR 7950 and HR 4468, and the CALSPEC spectrophotometric standard star, Feige 110 (Bohlin, Dickinson \& Calzetti 2001), were also observed for flux calibration purposes. In addition, Th-Ar comparison spectra, milky flats (sky flats obtained with a diffuser, during the afternoon) and bias frames were taken every night. The exposure time for standard stars was $5 \mathrm{~s}$ for the bright HR stars and $1200 \mathrm{~s}$ for Feige 110. 


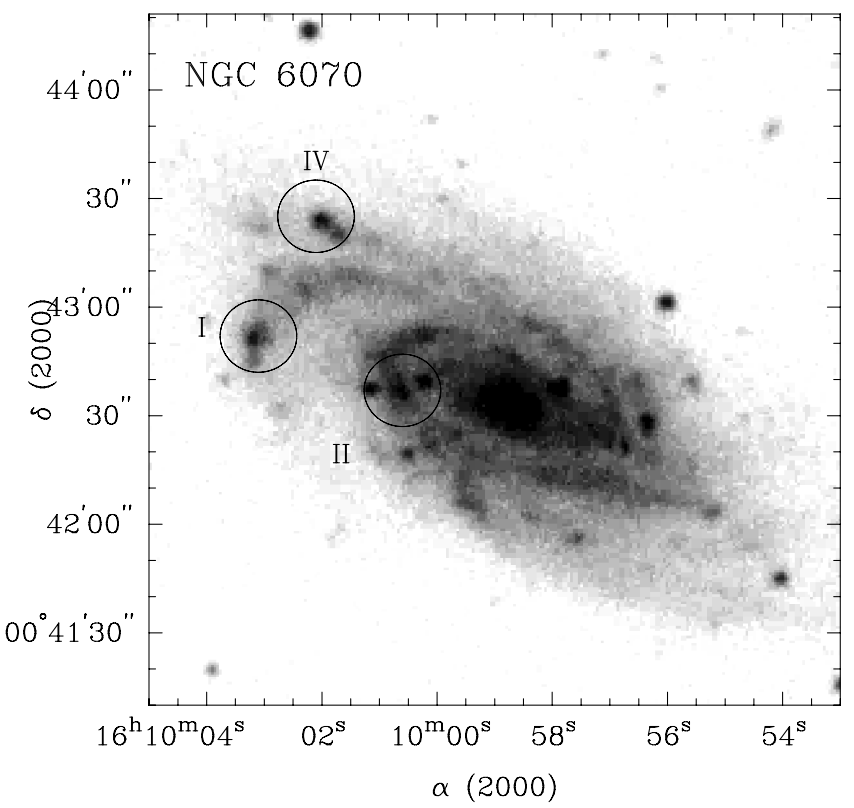

Figure 2. Same as Fig. 1 but for NGC 6070.

Table 1. Journal of observations for the candidate $\mathrm{GH}$ IIRs and flux standard stars. The candidate regions have labelled following their brightness ranking from Feinstein catalogue (see Feinstein 1997).

\begin{tabular}{llcccc}
\hline Telescope & Region & Date & Exp. & Sec $z$ & Standard \\
\hline du Pont & 7479 I & 2006 July 19 & 1800 & 1.6 & Feige 110 \\
& 7479 II & 2006 July 20 & 1800 & 1.5 & HR 7950 \\
& 7479 III & 2006 July 20 & 1800 & 1.4 & HR 7950 \\
& 6070 I & 2006 July 21 & 1800 & 1.2 & HR 4468 \\
& 6070 II & 2006 July 21 & 1800 & 1.2 & HR 4468 \\
& 6070 IV & 2006 July 21 & 1800 & 1.2 & HR 4468 \\
Clay & 6070 I & 2004 July 12 & 1800 & 1.3 & BD+28D4211 \\
& 6070 II & 2004 July 12 & 1800 & 1.2 & BD+28D4211 \\
& 6070 IV & 2004 July 12 & 1200 & 1.7 & BD+28D4211 \\
\hline
\end{tabular}

We also obtained high-resolution spectra for the three $\mathrm{H}$ II regions in the NGC 6070 galaxy using the echelle double spectrograph Magellan Inamori Kyocera Echelle (MIKE) at the 6.5-m Magellan II (Clay) Telescope, LCO, in 2004 July. No binning was applied to the $2 \mathrm{k} \times 4 \mathrm{k}$ CCD detector and a 1-arcsec slit was used. The spectral resolution measured on our MIKE spectra is $11 \mathrm{~km} \mathrm{~s}^{-1}$, which is quite similar than that obtained at du Pont. The exposure time for CALSPEC spectrophotometric standard star BD+28D4211 was $900 \mathrm{~s}$. Th-Ar comparison lamps, milky flats (internal flat field lamp with a diffuser glass slide) and bias frames were used to calibrate these data. Table 1 lists the journal of observations, together with the exposure times, airmasses and the standard stars that were used for flux calibrating each region.

The data analysis was carried out with $\mathrm{IRAF}^{1}$ software. After bias subtraction and flat-field corrections with Milky Flats, the bidimensional images were corrected for cosmic rays with the task CosMICRAYS which detects and removes cosmic rays using a flux ratio algorithm. The corrected data were reduced by IRAF routines following similar procedures to those described in Firpo et al. (2005).

${ }^{1}$ Image Reduction and Analysis Facility, distributed by NOAO, operated by AURA, Inc., under agreement with NSF.
We also compared the red end of the wavelength-calibrated spectra with the night-sky spectrum by Osterbrock et al. (1996). This turned out to be a very reliable confirmation of the goodness of the wavelength solution, and we were able to check that differences between our wavelengths and the sky line wavelengths were below $0.05 \AA$.

We performed flux calibrations using the observed spectrophotometric standard stars as described in Firpo et al. (2005). The observed standard stars had their fluxes tabulated every $16 \AA$, and the amount of defined intervals within an echelle order ranged from four to 12, depending on the quality of the spectrum.

For the Magellan spectra, and in the case of the NGC 7479 I region du Pont data, we were able to obtain CALSPEC spectrophotometric standard stars (Bohlin et al. 2001), whose fluxes were tabulated every $2 \AA$. These stars are ideal for calibrating high-resolution echelle spectra, although their relatively low brightness (Feige 110, $V=11.83$ and BD+28D4211, $V=10.51)$ makes them timeconsuming targets for 2-m class telescopes.

\section{ANALYSIS OF LINE PROFILES}

Making use of the known redshifts $z=0.006685$ for NGC 6070 (Springob et al. 2005) and $z=0.007942$ for NGC 7479 (Haynes et al. 1998) we identify the hydrogen recombination lines, such as $\mathrm{H} \alpha$ and $\mathrm{H} \beta$, and collisionally excited lines, such as [N II] $\lambda \lambda 6548$, $6584 \AA$, [S II] $\lambda \lambda 6717,6731 \AA$, present in the spectra. These strong lines are used to analyse the structure of the profiles as they allow us to verify the existence of more than one component. The adopted laboratory wavelengths are taken from work by García-Rojas et al. (2005).

To determine the radial velocities and the velocity dispersions of the ionized gas, we measure the central wavelength and width of several emission lines. The radial velocity of each emission line is obtained from its central wavelength determined from the Gaussian profile fitting, and their errors are given by the fitting error provided by the resampling done within the NGAUSS task of IRAF and taking into account the rms of the wavelength calibration. The true velocity dispersion $(\sigma)$ of each emission line is calculated as described in Firpo et al. (2005). The width of the observed profile $\left(\sigma_{\mathrm{o}}\right)$ is affected by the contribution of thermal random motions $\left(\sigma_{t}\right)$ and the instrumental profile $\left(\sigma_{\mathrm{i}}\right)$. Then, we can obtain the true velocity dispersion as $\sigma^{2}=\sigma_{\mathrm{o}}^{2}-\sigma_{\mathrm{i}}^{2}-\sigma_{\mathrm{t}}^{2}$. As in Firpo et al. (2005), a typical kinetic temperature $T=10^{4} \mathrm{~K}$ is assumed, and the instrumental profile $\left(\sigma_{\mathrm{i}}\right)$ is very well approximated by a single Gaussian function. The velocity dispersion errors have been calculated using the observational errors in the observed profile and assuming negligible errors in $\sigma_{\mathrm{i}}$ and $\sigma_{\mathrm{t}}$. Owing to the generally high metallicity of these kinds of objects as a class, the temperatures are probably lower than $10^{4} \mathrm{~K}$ (see Díaz et al. 2007, and references therein). The low excitation of these objects estimated from their spectra makes any temperature sensitive line too weak to be observed. In fact, in most cases, the [O III] $\lambda 5007 \AA$ line, which is typically 100 times more intense than the auroral [O III] $\lambda 4363 \AA$ one, can barely be seen. In this way, we have also calculated the velocity dispersions assuming a kinetic temperature of $5000 \mathrm{~K}$ and we do not find great differences with the previous calculations derived using $10^{4} \mathrm{~K}$. These differences are between 0.02 and $3 \mathrm{~km} \mathrm{~s}^{-1}$ depending on the measured velocity dispersion since $\sigma_{\mathrm{t}}$ is constant for a given temperature and subtracted in quadrature to $\sigma_{0}$. Obviously, the estimated $\sigma$ are always higher for the lower assumed kinetic temperatures. Then, for consistency with Firpo et al. (2005) we use a kinetic temperature of $10^{4} \mathrm{~K}$. Therefore, this effect owing to the kinetic temperature 
uncertainty, would produce an underestimation in the derived true velocity dispersions.

When fitting single Gaussian profiles to the emission lines we notice that, although it works well for most of the observed profiles, there is a residual present in the wings of several lines. This has been observed in GH IIRs before. Some authors (Melnick et al. 1999; Hägele et al. 2007, 2009, 2010, among others) have shown that the profile wings are well fitted by single (broad) Gaussian of supersonic widths, whereas other authors (Chu \& Kennicutt 1994; Relaño \& Beckman 2005; Rozas et al. 2006) proposed that the profiles appear to be dominated by a few, well-resolved, expanding shells. Wherever possible, we have considered and applied both suggestions.

In order to fit multiple components to the observed profiles we make use of the NGAUSSFIT task within IRAF. NGAUSSFIT performs iterative fitting of multiple Gaussian profiles to spectral lines. The task allows us to select individual parameters to be fitted and delivers an estimate for the uncertainty of derived parameters. The task needs initial guesses for the function coefficients, and these are specified through previously generated tables.

In those cases when more than one component is evident, we follow an iterative procedure in which we only allow the task to fit a limited subset of parameters at one time. This is done to constrain the universe of possible solutions to the fit by making use of the different information available from each emission line. Basically, after obtaining an initial guess for the second component parameters, we fit the amplitude, centre and width of each component at one time, leaving the parameters of the other one untouched. Once the central wavelength of all components is relatively well known, we set them as fixed parameters and allow the task to perform a final fit of amplitude and width of all components at the same time.
The profile fittings show the presence of a residual in the emission-line wings for all cases, becoming more evident in the strong $\mathrm{H} \alpha$ emission line. Therefore, we evaluate the presence of either a broad component or shell features. For the former assumption, we introduce a broad component with an initial width which is three times the width of the narrow component(s). This guess comes from an overall view of the values found by Hägele et al. (2007) when performing a similar analysis. We fit the peak values for the narrow components and then their profile widths. The broad component parameters are then fitted before we start the iterative procedure again. In the latter scenario, a similar iterative procedure takes place, but in this case we add a blue and a red narrow component to account for the additional emission. The validity of the profile multiplicity and broadening is checked over the different emission lines available for each region, although the most reliable profile analysis comes from the strongest lines, such as $\mathrm{H} \alpha$.

Out of our sample of six GH IIRs we find that all of them show evidence of wing broadening. For these regions we attempt to fit an overall broad component or two narrow components symmetrically shifted in velocity with respect to the intense component. In the following subsections we will discuss our findings grouping them by the outcome profiles.

\subsection{NGC 7479 I}

Rozas et al. (1999) undertook a complete study to date of the $\mathrm{H}_{\text {II }}$ regions in NGC 7479 galaxy, determining positions, angular sizes and absolute fluxes of over $1000 \mathrm{H}$ II regions and they constructed the luminosity function for the regions over the whole galaxy. We have cross-correlated these results with our sample and find that the three NGC 7479 regions selected in our work can be identified in the Rozas catalogue: NGC 7479 I as RZH99 = 1, NGC 7479 II

Table 2. Results of Gaussian profiles fitting to the observed emission lines in NGC 7479. Each emission line is identified by its ion laboratory wavelength and ion name in columns 1 and 2. According to the different fits performed on each line, column 3 identifies each 'narrow component' (A and B, where applicable), a broad component and/or blue and red wings ( $\mathrm{b}$ wing and $\mathrm{r}$ wing, respectively). Radial velocities $\left(V_{\mathrm{r}}\right)$ and intrinsic velocity dispersions $\left(\sigma_{\text {int }}\right)$ together with their respective errors are expressed in $\mathrm{km} \mathrm{s}^{-1}$. The intrinsic velocity dispersions are corrected for the instrumental and thermal widths. EMs are included and shown as a percentage of the component flux relative to the total EM of the region.

\begin{tabular}{|c|c|c|c|c|c|c|c|c|c|c|c|c|c|c|c|c|c|}
\hline \multirow[b]{2}{*}{$\lambda_{0}$} & \multirow[b]{2}{*}{ Ion } & \multirow[b]{2}{*}{ Comp. } & \multicolumn{5}{|c|}{ NGC 7479 I } & \multicolumn{5}{|c|}{ NGC 7479 II } & \multicolumn{5}{|c|}{ NGC 7479 III } \\
\hline & & & $V_{\mathrm{r}}$ & Error & $\sigma_{\text {int }}$ & Error & EM & $V_{\mathrm{r}}$ & Error & $\sigma_{\text {int }}$ & Error & EM & $V_{\mathrm{r}}$ & Error & $\sigma_{\text {int }}$ & Error & EM \\
\hline \multirow[t]{5}{*}{6563} & \multirow[t]{5}{*}{$\mathrm{H} \alpha$} & A & 2500.4 & 0.7 & 22.3 & 0.9 & 39 & 2492.4 & 0.6 & 14.8 & 0.8 & 66 & 2481.1 & 0.7 & 11.3 & 2.9 & 67 \\
\hline & & B & 2538.9 & 0.6 & 15.3 & 0.8 & 42 & 2532.2 & 0.7 & 11.1 & 0.9 & 23 & $\ldots$ & $\ldots$ & $\ldots$ & $\ldots$ & $\ldots$ \\
\hline & & Broad & 2519.6 & 3.9 & 76.5 & 4.8 & 19 & $\ldots$ & $\ldots$ & $\ldots$ & $\ldots$ & $\ldots$ & 2472.5 & 2.1 & 37.8 & 0.9 & 33 \\
\hline & & b wing & $\ldots$ & $\ldots$ & $\ldots$ & $\ldots$ & $\ldots$ & 2442.7 & 1.7 & 13.5 & 2.0 & 5 & $\ldots$ & $\ldots$ & $\cdots$ & $\ldots$ & $\ldots$ \\
\hline & & $\mathrm{r}$ wing & $\ldots$ & $\ldots$ & $\ldots$ & $\ldots$ & $\ldots$ & 2573.8 & 1.9 & 18.0 & 1.7 & 6 & $\ldots$ & $\ldots$ & $\ldots$ & $\cdots$ & $\cdots$ \\
\hline \multirow[t]{5}{*}{6584} & \multirow[t]{5}{*}[\mathrm{N}_{\text{III}}]{} & A & 2506.8 & 0.7 & 21.6 & 0.9 & 39 & 2494.2 & 1.1 & 16.4 & 1.0 & 53 & 2482.9 & 0.8 & 12.8 & 2.3 & 52 \\
\hline & & B & 2540.1 & 0.7 & 15.2 & 0.8 & 39 & 2532.5 & 2.0 & 16.7 & 1.3 & 30 & $\ldots$ & $\ldots$ & $\ldots$ & $\ldots$ & $\ldots$ \\
\hline & & Broad & 2523.4 & 4.4 & 63.6 & 3.6 & 22 & $\ldots$ & $\ldots$ & $\ldots$ & $\ldots$ & $\ldots$ & 2478.4 & 4.0 & 40.4 & 1.1 & 48 \\
\hline & & $\mathrm{b}$ wing & $\ldots$ & $\ldots$ & $\ldots$ & $\ldots$ & $\ldots$ & 2459.8 & 9.1 & 24.8 & 4.3 & 13 & $\ldots$ & $\ldots$ & $\cdots$ & $\ldots$ & $\ldots$ \\
\hline & & $r$ wing & $\ldots$ & $\ldots$ & $\cdots$ & $\ldots$ & $\ldots$ & 2581.5 & 6.5 & 14.7 & 2.5 & 4 & $\ldots$ & $\ldots$ & $\ldots$ & $\ldots$ & $\ldots$ \\
\hline \multirow[t]{5}{*}{6717} & \multirow[t]{5}{*}{ [S II] } & A & $\ldots$ & $\ldots$ & $\ldots$ & $\ldots$ & $\ldots$ & $\ldots$ & $\cdots$ & $\cdots$ & $\ldots$ & $\ldots$ & 2480.9 & 0.8 & 10.2 & 5.3 & 33 \\
\hline & & B & $\ldots$ & $\ldots$ & $\ldots$ & $\ldots$ & $\ldots$ & $\ldots$ & $\ldots$ & $\ldots$ & $\ldots$ & $\ldots$ & $\ldots$ & $\ldots$ & $\ldots$ & $\ldots$ & $\ldots$ \\
\hline & & Broad & $\ldots$ & $\ldots$ & $\ldots$ & $\ldots$ & $\ldots$ & $\ldots$ & $\ldots$ & $\ldots$ & $\ldots$ & $\ldots$ & 2471.1 & 4.1 & 52.2 & 1.4 & 67 \\
\hline & & b wing & $\cdots$ & $\cdots$ & $\cdots$ & $\cdots$ & $\cdots$ & $\cdots$ & $\cdots$ & $\cdots$ & $\cdots$ & $\cdots$ & $\cdots$ & $\cdots$ & $\cdots$ & $\cdots$ & $\cdots$ \\
\hline & & $\mathrm{r}$ wing & $\cdots$ & $\cdots$ & $\cdots$ & $\cdots$ & $\cdots$ & $\cdots$ & $\cdots$ & $\cdots$ & $\cdots$ & $\cdots$ & $\cdots$ & $\cdots$ & $\cdots$ & $\cdots$ & $\cdots$ \\
\hline \multirow[t]{5}{*}{6731} & \multirow[t]{5}{*}{ [S II] } & A & 2502.4 & 1.1 & 19.3 & 1.2 & 30 & $\ldots$ & $\ldots$ & $\ldots$ & $\ldots$ & $\ldots$ & 2481.0 & 0.8 & 15.4 & 4.3 & 50 \\
\hline & & B & 2538.0 & 0.8 & 14.3 & 0.9 & 39 & $\ldots$ & $\ldots$ & $\ldots$ & $\ldots$ & $\ldots$ & $\ldots \ldots$ & $\ldots$ & $\ldots$ & $\ldots$ & \\
\hline & & Broad & 2516.2 & 4.2 & 52.1 & 5.1 & 31 & $\ldots$ & $\ldots$ & $\ldots$ & $\ldots$ & $\ldots$ & 2454.7 & 6.4 & 51.8 & 1.2 & 50 \\
\hline & & b wing & $\cdots$ & $\cdots$ & $\cdots$ & $\ldots$ & $\cdots$ & $\cdots$ & $\cdots$ & $\cdots$ & $\cdots$ & $\cdots$ & $\cdots$ & $\ldots$ & $\ldots$ & $\ldots$ & $\ldots$ \\
\hline & & $\mathrm{r}$ wing & $\cdots$ & $\cdots$ & $\cdots$ & $\cdots$ & $\cdots$ & $\cdots$ & $\cdots$ & $\cdots$ & $\cdots$ & $\cdots$ & $\cdots$ & $\cdots$ & $\cdots$ & $\cdots$ & $\cdots$ \\
\hline
\end{tabular}



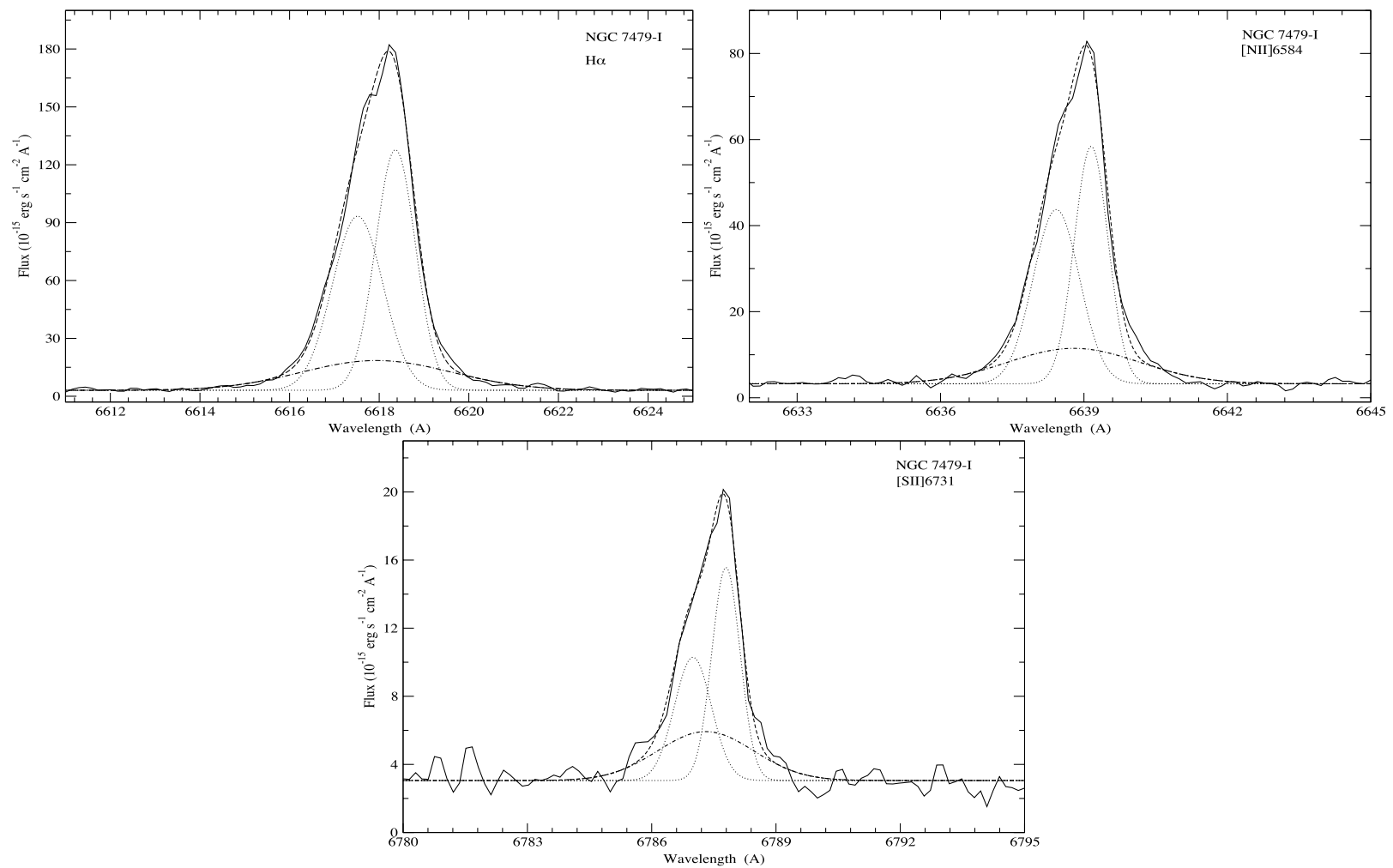

Figure 3. NGAUSS fits with three Gaussian components in the NGC 7479 I emission-line profiles, two narrow principal components and a broad one. In order: $\mathrm{H} \alpha,\left[\mathrm{N}_{\text {II }}\right] \lambda 6584 \AA$ and $\left[\mathrm{S}_{\text {II }}\right] \lambda 6731 \AA$.

as RZH99 $=7$ and NGC $7479 \mathrm{III}$ as RZH99 $=74$ (RZH99 is the number identification used by Rozas et al. 1999).

We identify and fit the Gaussian profiles to the $\mathrm{H} \alpha$, [N II] $\lambda 6584 \AA$ and $\left[\mathrm{S}_{\mathrm{II}}\right] \lambda \lambda 6717,6731 \AA$ lines in NGC 7479 I region with SPLOT routines. The Gaussian fits reveal the presence of two distinctly separated kinematic components (labelled A and B) in all analysed profiles. Component A shows a much broader profile than component $\mathrm{B}$, and both components show little spread in their individual radial velocities among different emission lines present in the spectrum. The reliability of these values is confirmed when we improve the profile fitting using NGAUSSFIT which in turn yields values for the profile width of each component.

Even considering the presence of two distinct components with different radial velocities, the overall fit cannot account for a residual emission in the profile wings. Following the procedures outlined in the previous section, we are able to fit a broad component, with a velocity dispersion of about $75 \mathrm{~km} \mathrm{~s}^{-1}$ from the $\mathrm{H} \alpha$ emission line

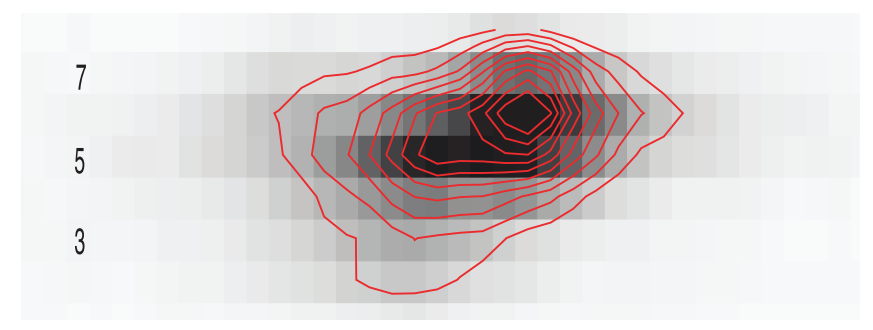

Figure 4. $2 \mathrm{D} \mathrm{H} \alpha$ velocity image of NGC 7479 I region with the [ $\left.\mathrm{N}_{\mathrm{II}}\right]$ $\lambda 6584 \AA$ (red) contours overlapped. Three sections are numbered in the $2 \mathrm{D}$ image.
Table 3. Gaussian fitting results for individual sections of the $\mathrm{H} \alpha$ emissionline profile in NGC 7479I. Kinematical parameters [radial velocity $\left(V_{\mathrm{r}}\right)$ with errors $\left(\mathrm{km} \mathrm{s}^{-1}\right)$ ], the intrinsic velocity dispersions $\left(\sigma_{\text {int }}\right)$ corrected for the instrumental and thermal widths $\left(\mathrm{km} \mathrm{s}^{-1}\right)$ and $\mathrm{EM}$ of each component as a fraction of the total EM of the sampled section (per cent) data are shown.

\begin{tabular}{llclllll}
\hline$\lambda_{0}$ & Section & Comp & $V_{\mathrm{r}}$ & Error & $\sigma_{\text {int }}$ & Error & EM \\
\hline 6563 & $\mathrm{H} \alpha-1$ & A & 2501.8 & 0.9 & 12.6 & 1.2 & 51 \\
& & Broad & 2500.7 & 4.8 & 59.3 & 4.3 & 49 \\
6563 & $\mathrm{H} \alpha-2$ & A & 2503.0 & 0.9 & 11.6 & 1.5 & 63 \\
& & Broad & 2500.3 & 1.6 & 37.7 & 2.5 & 37 \\
6563 & $\mathrm{H} \alpha-3$ & A & 2504.7 & 0.6 & 16.4 & 0.8 & 43 \\
& & Broad & 2506.8 & 1.4 & 47.0 & 1.7 & 57 \\
6563 & $\mathrm{H} \alpha-4$ & A & 2500.8 & 0.7 & 15.8 & 0.9 & 43 \\
& & Broad & 2519.6 & 2.9 & 55.0 & 3.6 & 30 \\
& & B & 2536.8 & 0.7 & 10.7 & 0.9 & 27 \\
6563 & $\mathrm{H} \alpha-5$ & A & 2500.9 & 0.6 & 10.5 & 0.8 & 25 \\
& & Broad & 2515.6 & 1.5 & 55.9 & 1.9 & 35 \\
& & B & 2535.6 & 0.6 & 13.1 & 0.8 & 40 \\
6563 & $\mathrm{H} \alpha-6$ & Broad & 2502.6 & 1.5 & 45.5 & 1.7 & 39 \\
& & B & 2538.6 & 0.6 & 17.4 & 0.8 & 61 \\
6563 & $\mathrm{H} \alpha-7$ & Broad & 2519.4 & 1.2 & 46.0 & 1.3 & 56 \\
& & B & 2540.7 & 0.6 & 6.0 & 0.8 & 44 \\
6563 & $\mathrm{H} \alpha-8$ & Broad & 2523.9 & 2.1 & 44.9 & 1.9 & 80 \\
& & B & 2532.6 & 0.6 & $\ldots$ & 1.2 & 20 \\
\hline
\end{tabular}


and about $60 \mathrm{~km} \mathrm{~s}^{-1}$ from the other ones. An attempt to fit twin narrow profiles did not converge to a reliable solution. Table 2 shows parameters for the three components that fit the global profile. Individual Gaussian component fluxes are listed as emission measure (EM) relative to the total line flux following the work by Relaño \& Beckman (2005). The overall $\mathrm{H} \alpha$ flux, uncorrected for reddening, is found to be $3.37 \times 10^{-14} \mathrm{erg} \mathrm{s}^{-1} \mathrm{~cm}^{-2}$. In Fig. 3 we show the NGAUSS fitting done with three different Gaussian components in the emission lines which have enough signal to provide an accurate fit. The emission lines with a low signal-to-noise ratio for which the fits do not provide accurate results for the broad component are not listed in the table. The velocity dispersion for the ionized gas is derived by taking $\sigma_{\mathrm{i}}=5.1 \mathrm{~km} \mathrm{~s}^{-1}$ as instrumental width, and a kinetic temperature of $T \simeq 10^{4} \mathrm{~K}$ as mentioned above.

Since part of the spatial information along the slit is lost through the aperture extraction process we generate $2 \mathrm{D}$ velocity images in $\mathrm{H} \alpha,\left[\mathrm{N}_{\mathrm{II}}\right] \lambda 6584 \AA$ and $\left[\mathrm{S}_{\mathrm{II}}\right] \lambda 6717 \AA$ lines. Taking into account that the slit size is $1 \times 4 \operatorname{arcsec}^{2}$, the data are binned by 2 pixels in both directions and the seeing was 1 arcsec, we take aperture
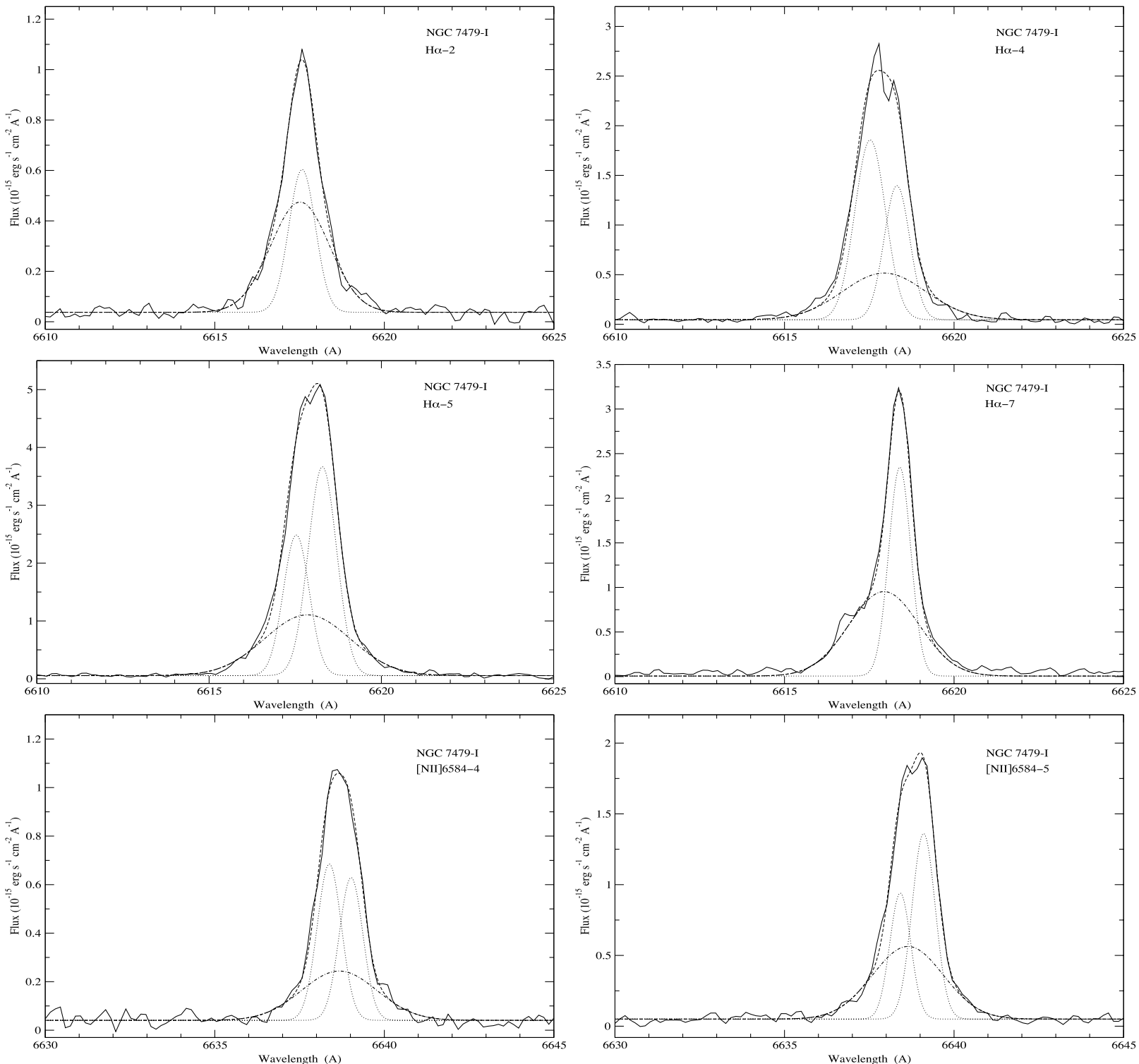

Figure 5. NGauss fits with three (two) Gaussian components in the NGC 7479 I sections, two (one) narrow principal components and a broad one. In order: $\mathrm{H} \alpha$ (sections 2, 4, 5 and 7), [N II] $\lambda 6584 \AA$ (sections 4 and 5).

sizes of $0.5 \operatorname{arcsec} \simeq 1$ pixel, therefore, dividing the slit into eight sections. We extract traces of the spectrum at eight representative cuts along the slit, preserving the same spatial resolution. This is done for each echelle order where a line of interest is present and each spectral section is rebinned to velocity space. In this reference frame, individual slices are stacked together using the IMSTACK task, which allows us to generate $2 \mathrm{D}$ velocity images. Fig. 4 shows the $2 \mathrm{D} \mathrm{H} \alpha$ velocity image with the [N $\mathrm{NI}] \lambda 6584 \AA$ A contours overlapped. It can be readily seen that individual knots can only be identified when the kinematical information is considered in this $V_{\mathrm{r}}$ versus slit section plane. This suggests that $3 \mathrm{D}$ spectroscopy will be able to provide a powerful insight on the structure of this type of starforming knots.

We have performed a detailed analysis on the slit stack, by fitting Gaussian profiles at each slit section. The resulting parameters are listed in Table 3 and the graphics output can be seen in Fig. 5, where shown 2, 4, 5 and $7 \mathrm{H} \alpha$ sections, and 4 and 5 [N II] $\lambda 6584 \AA$ sections. Focusing on the slit edges first (sections 1 to 3 and 6 to 8 ) we identify two distinct kinematical components at 2500 and
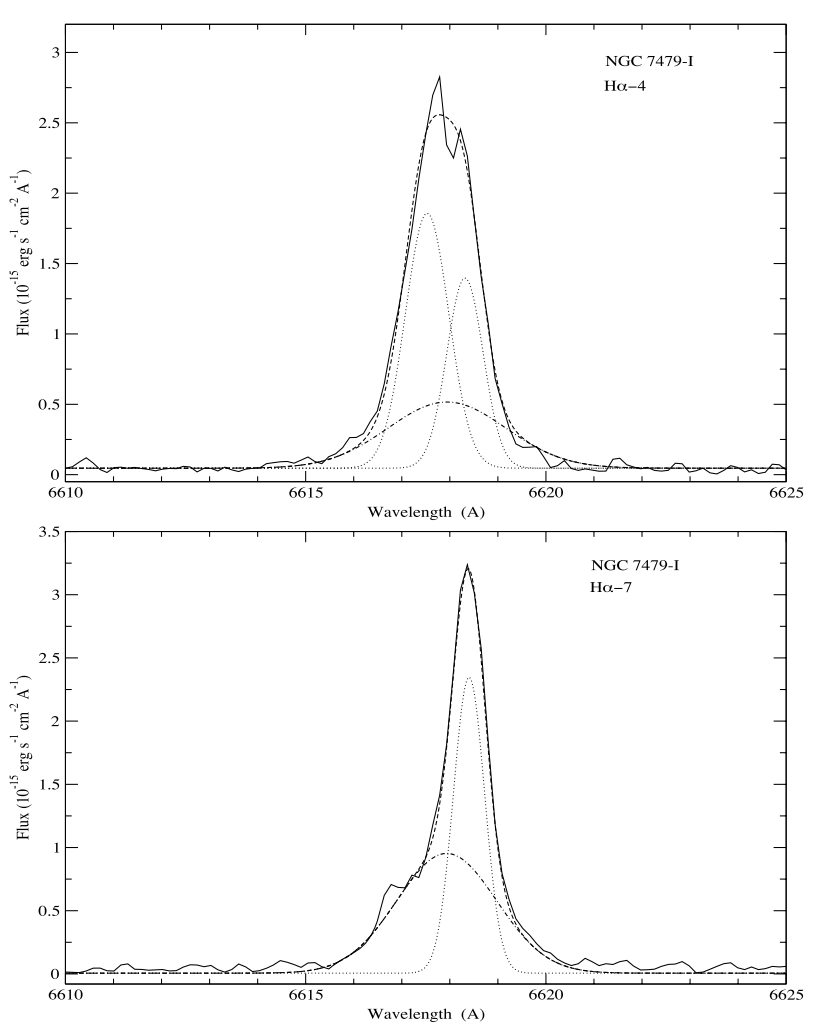
$2540 \mathrm{~km} \mathrm{~s}^{-1}$ labelled A and B, respectively. Each of these relatively narrow features has a broader component associated with it. Although the narrow component can still be deblended in the central region, we are not able to disentangle the broad ones, which results in a single broad profile with a velocity similar to the average between components $\mathrm{A}$ and $\mathrm{B}$. Regarding the velocity dispersion of each component, we have listed them in Table 3 as a reference, but they should not be taken as a definite value as the signal-to-noise ratio is variable and somewhat low for the slit edges.

If we compare these results with the radial velocity map derived for the ionized gas in NGC 7479 (Laine 1996) we find, from visual inspection, that the expected velocity at the position of NGC 7479 I ranges between 2520 and $2535 \mathrm{~km} \mathrm{~s}^{-1}$ close to an average value of our components A and B. A similar comparison, using the $\mathrm{H}_{\mathrm{I}}$

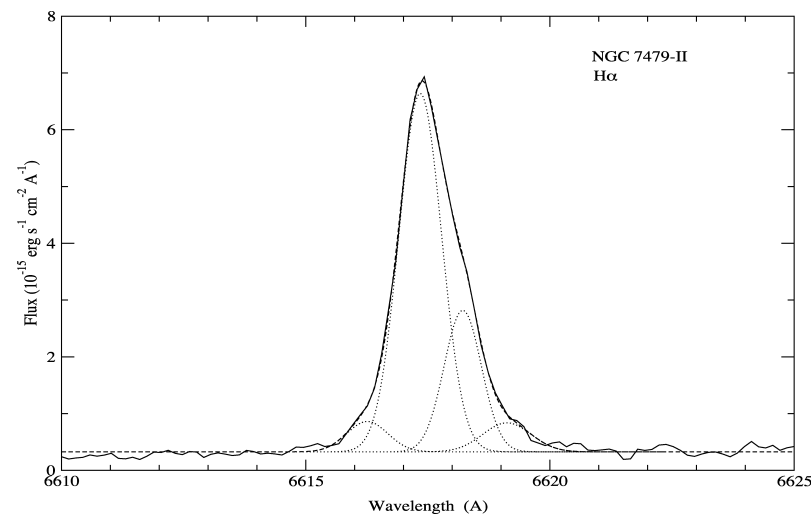

map by Laine \& Gottesman (1998) which has a better spatial and spectral resolution, yields a value between 2530 and $2540 \mathrm{~km} \mathrm{~s}^{-1}$ much closer to the value measured for component B. Although the latter map is sampling neutral rather than ionized hydrogen, the former might be affected by the complex structure we find within the region. At this stage we can only suggest that component $\mathrm{A}$ shows an odd kinematic behaviour and that a detailed study of NGC 7479 I and its surroundings is needed to clarify this issue.

\subsection{NGC 7479 II}

A similar procedure is used to analyse the profiles of the emission lines of NGC 7479 II. In this case, two components are identified with different radial velocities, but as the overall signal obtained

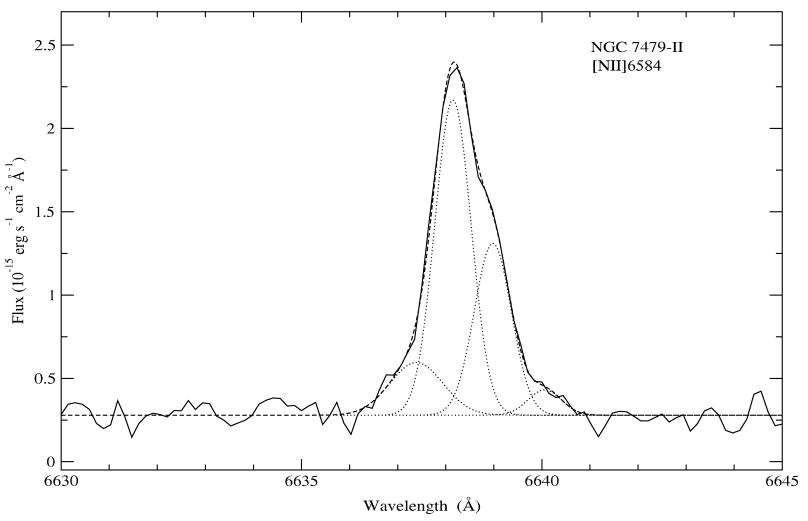

Figure 6. NGAUSS fits with four Gaussian components in the NGC 7479 II emission-line profiles, two narrow principal components and two low-intensity components. In order: $\mathrm{H} \alpha$ and $[\mathrm{N}$ II] $6584 \AA$.
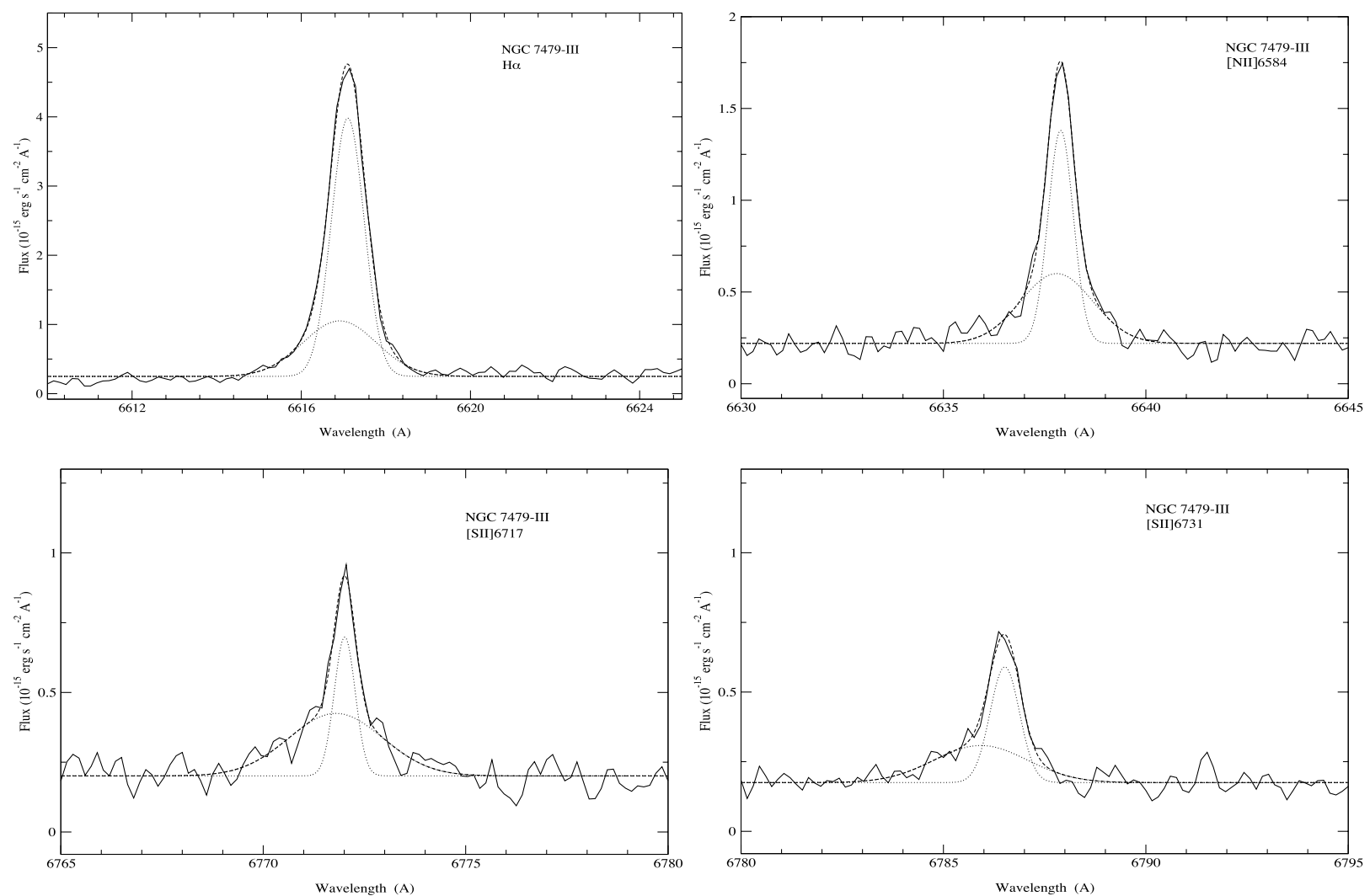

Figure 7. NGAUSS fits with two Gaussian components in the NGC 7479 III emission-line profiles. In order from left to right and from top to bottom: $\mathrm{H} \alpha$, [N II] $\lambda 6584 \AA,\left[\mathrm{S}_{\text {II }}\right] \lambda 6717 \AA$ and $\left[\mathrm{S}_{\text {II }}\right] \lambda 6731 \AA$. 

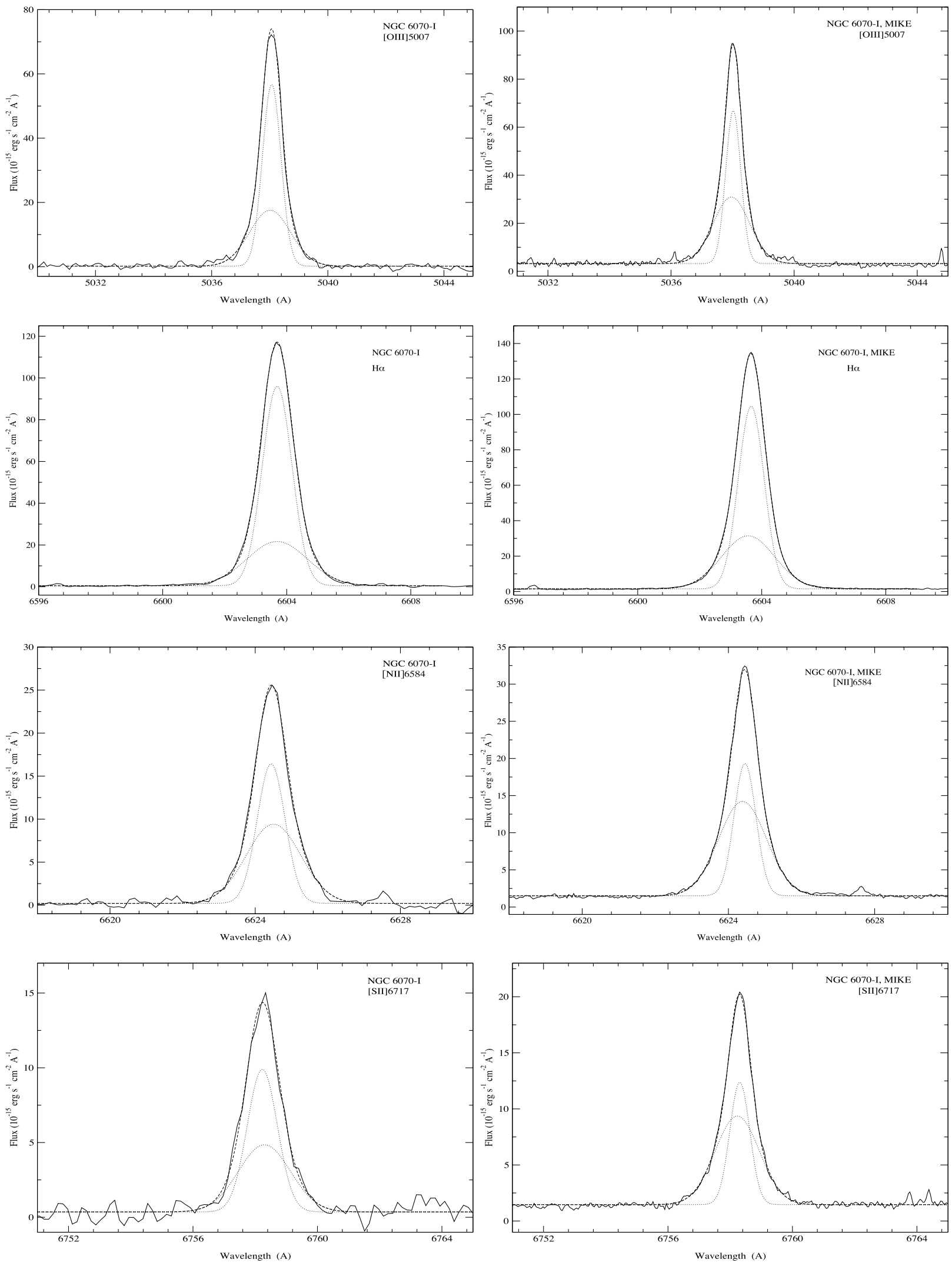

Figure 8. NGAuss fits with two Gaussian components in the NGC 6070 I emission-line profiles. du Pont data on the left-hand side and MIKE data on the right-hand side. In order from top to bottom panels: [O III] $\lambda 5007 \AA, \mathrm{H} \alpha,\left[\mathrm{N}_{\mathrm{II}}\right] \lambda 6584 \AA$ and $\left[\mathrm{S}_{\mathrm{II}}\right] \lambda 6717 \AA$. NGAuss fits with two Gaussian components in the NGC 6070 I emission line profiles. du Pont data on the left-hand side and MIKE data on the right-hand side for [S II] $\lambda 6731 \AA$ line. 

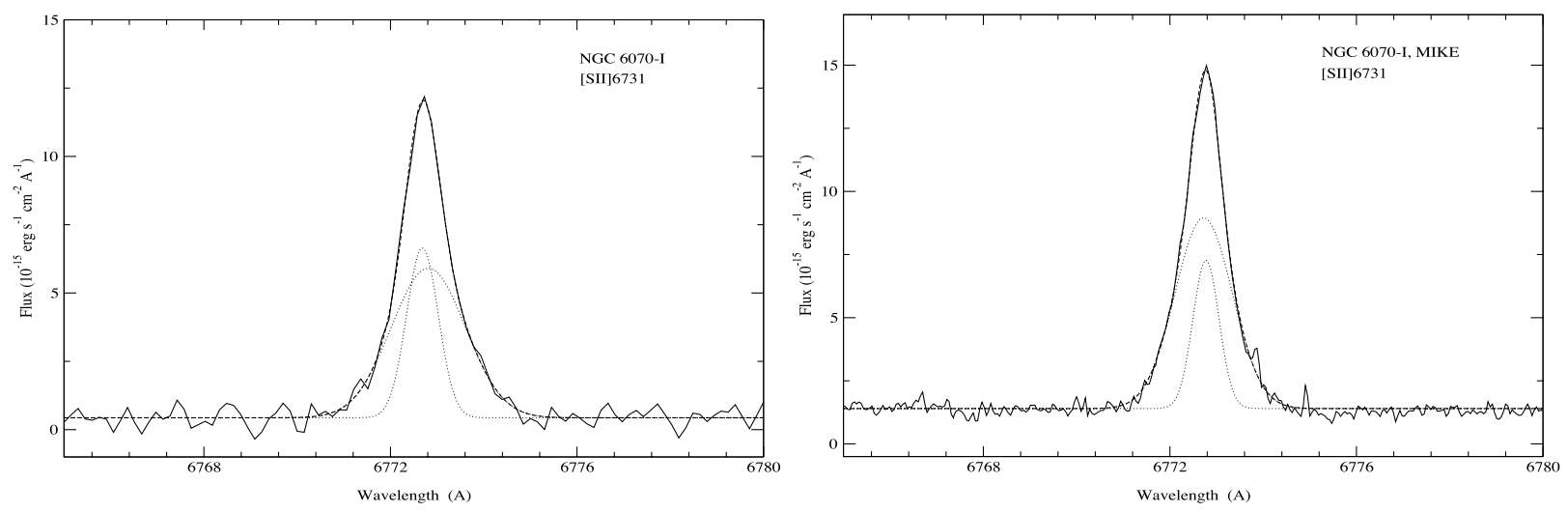

Figure 8 - continued

for this region is lower than for NGC 7479 I it is not possible to disentangle them with $2 \mathrm{D}$ spectra. These two narrow components are found in the Gaussian profiles of the $\mathrm{H} \alpha, \mathrm{H} \beta$, [N II] $\lambda \lambda 6548$, $6584 \AA$ and $\left[\mathrm{S}_{\mathrm{II}}\right] \lambda \lambda 6717,6731 \AA$ lines. In this region, however, the wings of the brightest component profile could not be fitted with one single broad component. On the other hand, we are able to fit it with two wings only for the two lines with the strongest signal, namely $\mathrm{H} \alpha$ and $\left[\mathrm{N}_{\mathrm{II}}\right] \lambda 6584 \AA$ (see Fig. 6). The final fitting parameters are shown in Table 2. The overall $\mathrm{H} \alpha$ flux, uncorrected for reddening, is found to be $1.06 \times 10^{-14} \mathrm{erg} \mathrm{s}^{-1} \mathrm{~cm}^{-2}$. The emission lines with a low signal-to-noise ratio for which the fits do not provide accurate results for the broad and the two wings components are not listed in the table.

We compare the velocity separation between the redshifted (and blueshifted) components with the average of the central features and the $\mathrm{H} \alpha$ luminosity of the region. The velocity separation of the red- and blueshifted components in this work is in agreement with the regression found by Relaño \& Beckman (2005) for their H II regions sample.

We also analyse the radial velocity behaviour within the galaxy, and observe a similar situation to that of NGC 7479 I. There is no difference, within the errors, when we compare our average value derived from the $\mathrm{H} \alpha$ emission line with the $\mathrm{H} \alpha$ velocities field map (Laine 1996). If, however, the comparison is done against the $\mathrm{H}_{\mathrm{I}}$ rotation velocity map (Laine \& Gottesman 1998), knot B seems to follow galactic rotation whereas knot A does not.

\subsection{NGC 7479 III}

The observed spectrum of this region shows, although weak, the [O III] $\lambda \lambda 4959,5007 \AA$ lines. This is probably owed to a difference in metallicity, NGC 7479 III being slightly less metallic than the brightest two regions discussed above, or a difference in the ionization structure. The latter might be due to a relatively small difference in the hardness of the ionization radiation field (and, what is equivalent, in the ionizing stellar population) responsible for the excitation observed in the spectra or a difference in the nebular geometry (see a detailed discussion in Hägele et al. 2006, 2008; Díaz et al. 2007; Pérez-Montero et al. 2010, and references therein). Unfortunately, as we said above, since no temperature sensitive lines can be observed, we are not able to derive their metallicities, and distinguish the origin of this small difference in the excitation present in the spectra of these regions of NGC 7479.

We identify and fit the Gaussian profiles to the [O III] $\lambda 5007 \AA$, $\mathrm{H} \alpha,\left[\mathrm{N}_{\mathrm{II}}\right] \lambda 6584 \AA$ and $[\mathrm{S}$ II] $\lambda \lambda 6717,6731 \AA$ A lines in NGC 7479 III region with NGAUSSFIT. In this region we have found one supersonic component, with no evidence of multiple contributions but it is possible to detect flux excess on the wings of the emission lines. We therefore fit a broad Gaussian component together with the narrow component (see Fig. 7). This procedure works well for almost all detected lines. In the case of [O III] $\lambda 5007 \AA$, however, there are no prominent residuals when we fit only one Gaussian component which has a dispersion of about $20 \mathrm{~km} \mathrm{~s}^{-1}$ and we are therefore not able to fit a broad Gaussian component. For the other listed lines the derived radial velocities, the velocity dispersions (using $\sigma_{\mathrm{i}}^{2}=5.4 \mathrm{~km} \mathrm{~s}^{-1}$ and $T \simeq 10^{4} \mathrm{~K}$ ) and errors are listed in Table 2 . The overall $\mathrm{H} \alpha$ flux, uncorrected for reddening, is found to be $5.43 \times 10^{-15} \mathrm{erg} \mathrm{s}^{-1} \mathrm{~cm}^{-2}$. It is worth mentioning that there seems to be some systematic offset between the derived profile centres of the narrow and broad profiles which is, in average, about $10 \mathrm{~km} \mathrm{~s}^{-1}$. This happens for all lines, although it becomes more evident for [S II] $\lambda 6731 \AA$ A. An undiscovered blueshifted narrow component could account for the observed behaviour, although better signal-to-noise ratio data are needed to confirm this hypothesis.

The radial velocity average derived for the single component is in agreement with the expected radial velocity at the position of NGC 7479 III, showing only a slight offset of $\left(10 \mathrm{~km} \mathrm{~s}^{-1}\right)$, well within the uncertainties.

\subsection{NGC 6070 I, II and IV}

All regions observed in NGC 6070 show one narrow component together with the underlying broad component. We identify and fit the Gaussian profiles to the $\mathrm{H} \beta$, [O $\left.{ }_{\text {III }}\right] \lambda 5007 \AA, \mathrm{H} \alpha$, [N II] $\lambda 6584 \AA$ and $[\mathrm{S}$ II $] \lambda \lambda 6717,6731 \AA$ lines in almost all regions (see Figs 8-10). Table 4 shows the derived kinematical parameters (using $\sigma_{i}^{2}=5.3$, 5.6 and $5.3 \mathrm{~km} \mathrm{~s}^{-1}$ for regions I, II and IV, respectively; $T$ is set to $\simeq 10^{4} \mathrm{~K}$ for all regions).

For these three regions, we are also able to compare the du Pont data with higher resolution spectra data obtained with the double echelle spectrograph MIKE in 2004 July. The agreement in the kinematical parameters can be seen in Table 4, which shows the reliability of the data here presented. The overall $\mathrm{H} \alpha$ flux, uncorrected for reddening, for du Pont data are $1.68 \times 10^{-13}, 6.26 \times 10^{-14}$ and $2.15 \times 10^{-13} \mathrm{erg} \mathrm{s}^{-1} \mathrm{~cm}^{-2}$ for regions I, II and IV, respectively, and for MIKE data are $1.74 \times 10^{-13}, 1.29 \times 10^{-13}$ and $1.88 \times 10^{-13} \mathrm{erg} \mathrm{s}^{-1} \mathrm{~cm}^{-2}$. Only a slight bias towards lower velocity dispersion can be seen for NGC 6070 I, which can be probably attributed to differences in the centring of the slit during acquisition of the target. There seems to be some systematic offset between 

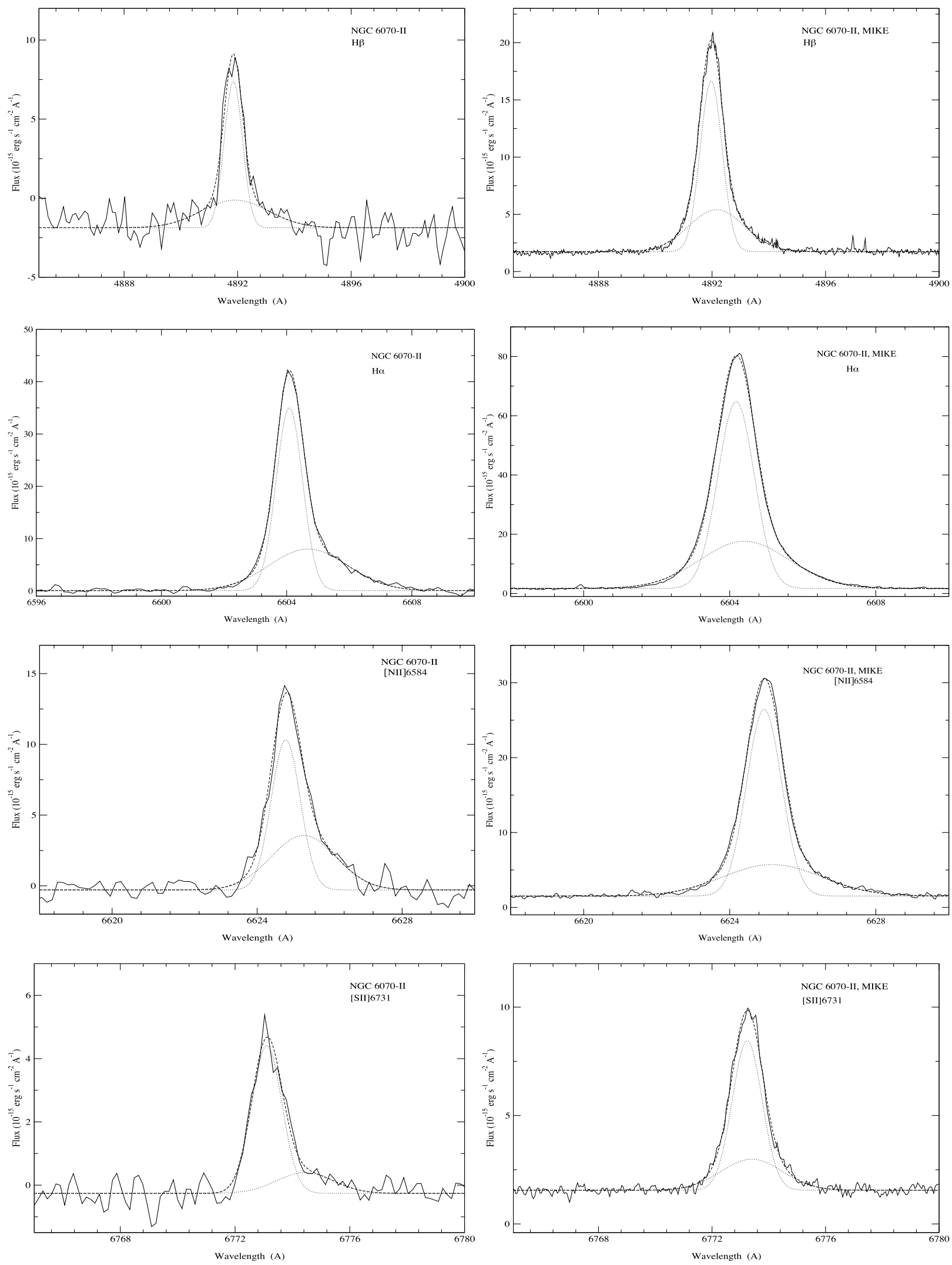

Figure 9. NGAuss fits with two Gaussian components in the NGC 6070 II emission-line profiles. du Pont data on the left-hand side and MIKE data on the right-hand side. In order from top to bottom panels: $\mathrm{H} \beta, \mathrm{H} \alpha,\left[\mathrm{N}_{\mathrm{II}}\right] \lambda 6584 \AA$ and [ $\left.\mathrm{S}_{\mathrm{II}}\right] \lambda 6731 \AA$. 

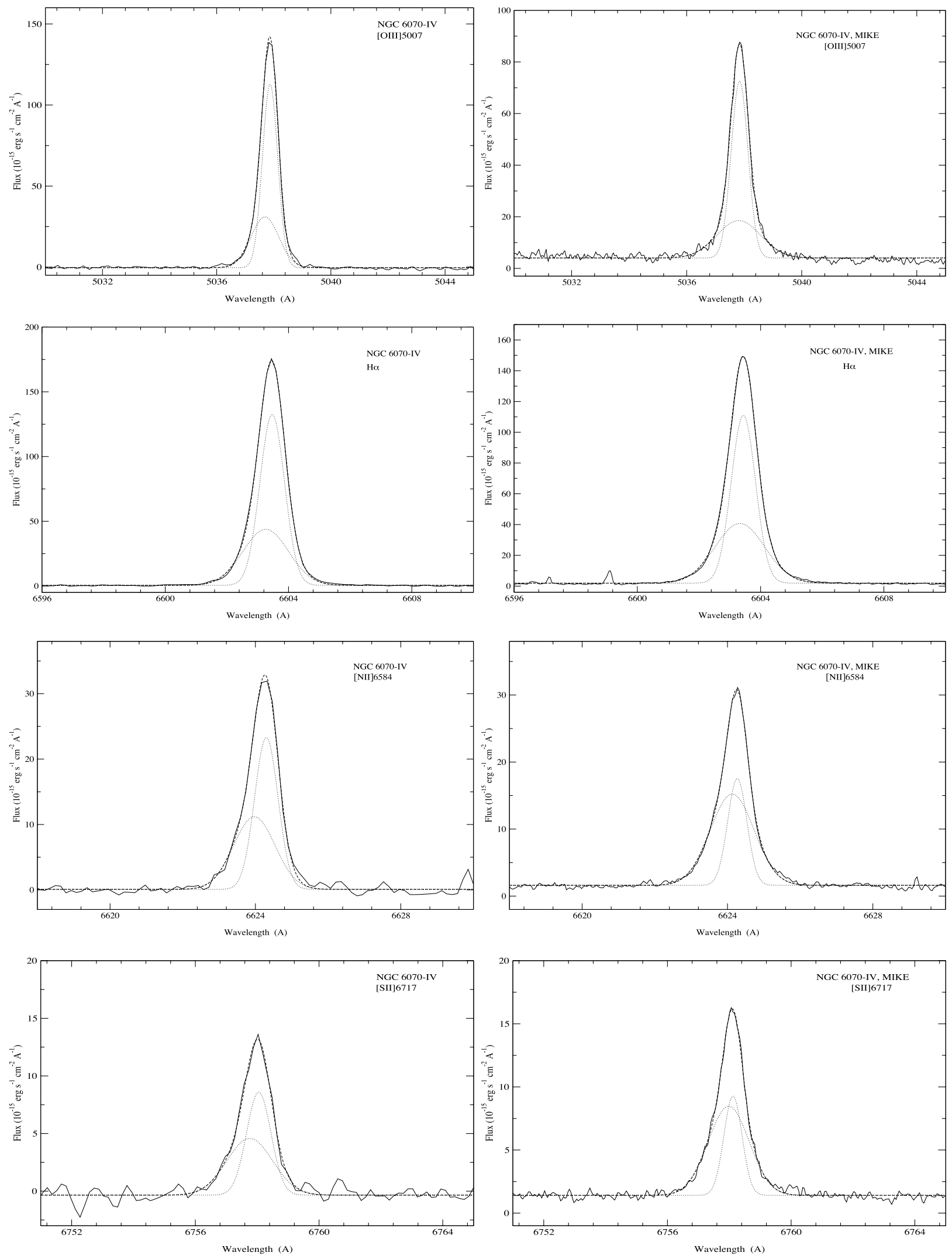

Figure 10. NGAUSS fits with two Gaussian components in the NGC 6070 IV emission-line profiles. du Pont data on the left-hand side and MIKE data on the right-hand side. In order from top to bottom panels: [O III] $\lambda 5007 \AA$, $\mathrm{H} \alpha,[\mathrm{N}$ II] $\lambda 6584 \AA$ and [S II] $\lambda 6717 \AA$. 
Table 4. Results of Gaussian profiles fitting to the observed emission lines in NGC 6070. Each emission line is identified by its ion laboratory wavelength and ion name in columns 1 and 2. According to the different fits performed on each line, column 3 identifies each 'narrow component' (A and B, where applicable), a broad component and/or blue and red wings ( $\mathrm{b}$ wing and $\mathrm{r}$ wing, respectively). Radial velocities $\left(V_{\mathrm{r}}\right)$ and intrinsic velocity dispersions $\left(\sigma_{\text {int }}\right)$ together with their respective errors are expressed in $\mathrm{km} \mathrm{s}^{-1}$. The intrinsic velocity dispersions are corrected for the instrumental and thermal widths. EMs are included and shown as a percentage of the component flux relative to the total EM of the region. Upper panel: du Pont data; lower panel: MIKE data.

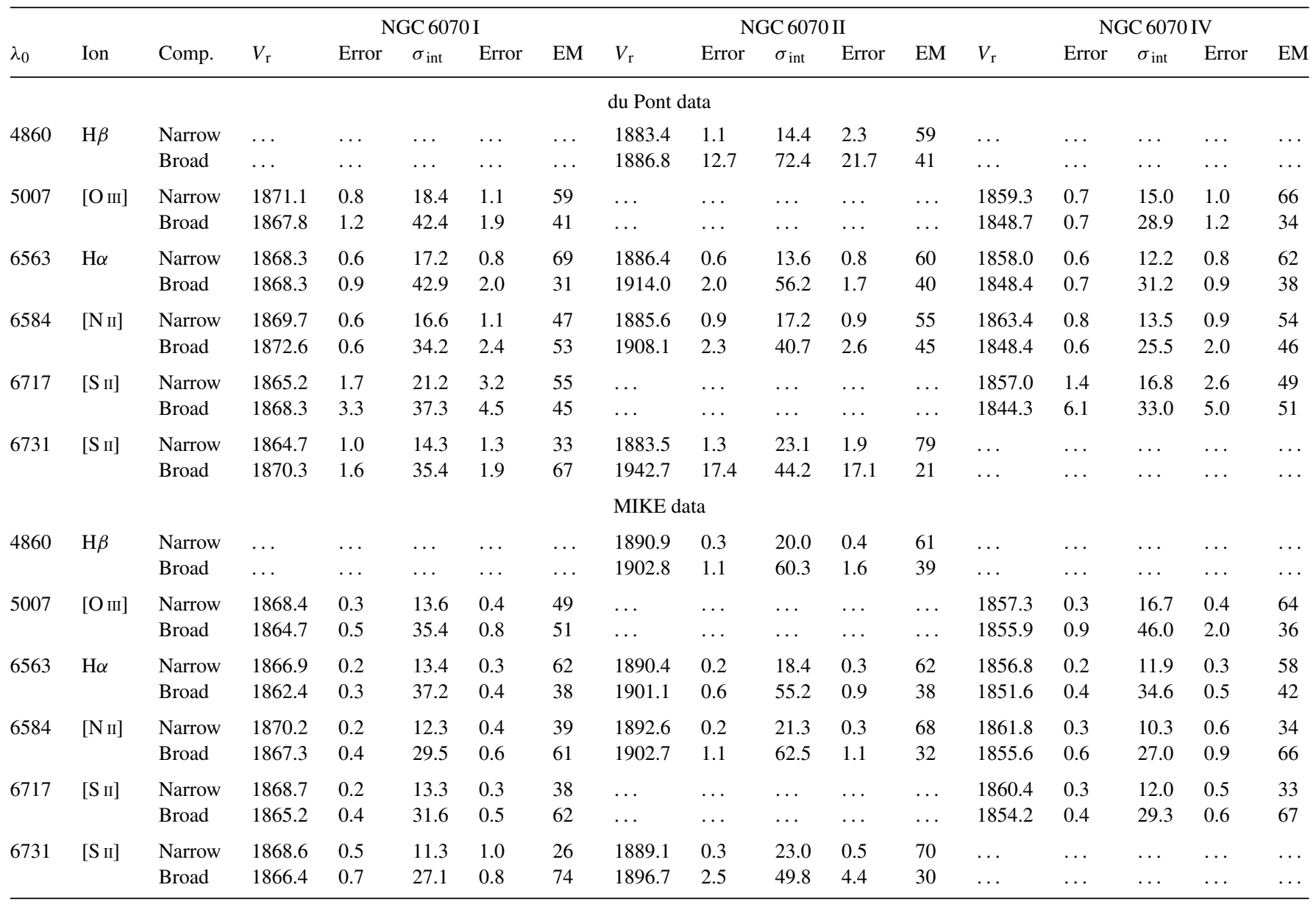

the derived profile centres of the narrow and broad profiles. Theses values are, in average, about $-25 \mathrm{~km} \mathrm{~s}^{-1}$ for du Pont data and $-10 \mathrm{~km} \mathrm{~s}^{-1}$ for MIKE data in the case of NGC $6070 \mathrm{II}$, and about 10 and $5 \mathrm{~km} \mathrm{~s}^{-1}$ for NGC $6070 \mathrm{IV}$.

Regarding radial velocities of the three observed regions in NGC 6070, there is no detailed velocity map in the literature. We are able to compare them with rotation curves derived from long slit observations made by Márquez et al. (2002). Although the orientation of the slits does not match exactly the location of all our regions, the velocities are in fair agreement considering the angular distance of the $\mathrm{H}$ II regions to the centre of NGC 6070.

\subsection{Relation between $\mathrm{H} \alpha$ luminosities and velocity dispersion}

We have also analysed the impact that the presence of multiple components has on the location of $\mathrm{H}$ II regions in the $\log (L)-\log (\sigma)$ plane. To evaluate this we have plotted in Fig. 11 the luminosities and velocity dispersions derived directly from our spectrophotometric data. Luminosities were derived from the fluxes measured directly from the component fitting to our echelle spectra (uncorrected by reddening), and using distances as published by Rozas et al. (1999) for NGC 7479 and by García-Gómez et al. (2002) for NGC 6070. We are aware that slit spectra might not provide the most realistic sample of the overall flux of the ionized nebula, but the accuracy of acquisition and guiding is not good enough as to allow us to perform a proper identification with published luminosity values in fields relatively 'crowded' with H II regions by Feinstein (1997) and Rozas et al. (2006). Velocity dispersion values and its errors are taken directly from Tables 2 and 4 . The luminosity errors have been estimated taking into account the errors in the amplitude $(A)$ and the FWHM in the component fitting $(F=1.0645 \times A \times \mathrm{FWHM})$, and the distance errors. As a reference value we have plotted a few giant $\mathrm{H}$ II regions from Bosch et al. (2002) together with their linear fit to their 'young' GH II regions.

Inspection of Fig. 11 reveals that the distribution of points in the $\log (L)-\log \left(\sigma_{\text {int }}\right)$ plane are strongly dependent on the components derived from the profile fitting. Individual components, labelled A and $\mathrm{B}$ (when applicable) as in their respective tables, and global values are those derived from a single Gaussian fitting to the line profile. As expected, individual components have smaller fluxes and velocity dispersions than the global profile and points are therefore shifted in the diagram. The incidence of this analysis has, however, a different outcome for regions in NGC 6070 and NGC 7479. In NGC 6070 the values derived from the global profile seem to lie, within observational errors, in the expected location if they follow the relation expected for virialized systems. When the individual components are plotted in the same diagram, only NGC 6070 II lies close to the regression, and NGC 6070 I and IV seem to be too 


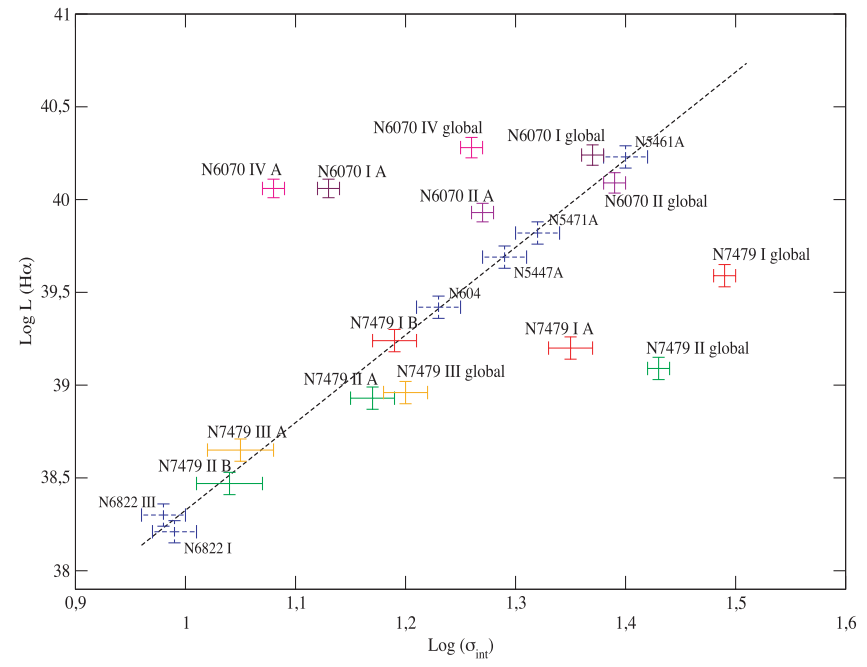

Figure 11. $\log (L)-\log (\sigma)$ relation for our $\mathrm{H}_{\text {II }}$ regions. Luminosities and velocity dispersions are derived from our spectrophotometric data. The plot includes results from individual components labelled A and B (where applicable) together with velocity dispersions for the overall profile (labelled as 'global') which were derived from a single Gaussian fitting to the line profile (colour solid error bars). The narrow components in NGC 6070 were labelled A, for which we only plot the MIKE measured data. A few giant $\mathrm{H}$ II regions from Bosch et al. (2002) (blue dashed error bars) together with their linear fit to their 'young' giant $\mathrm{H}_{\mathrm{II}}$ regions are plotted as a reference value. The luminosities are not corrected for extinction.

luminous for their measured velocity dispersion. On the other hand, two out of three regions in NGC 7479 lie well away this regression if parameters are derived from a single Gaussian, but four out of five individual components show a very good agreement when plotted in the same diagram.

The interpretation of this behaviour is not straightforward. Definitely, the presence of more than one Gaussian component rules the final position of the $\mathrm{H}$ II regions in the $\log (L)-\log (\sigma)$ plane. Our high-resolution spectroscopic data have allowed us to disentangle multiple kinematic components, which reflects in a big improvement in the $x$-axis of the plot. However limitations in spatial resolution prevent us from identifying multiple components, if present, which do not become evident in the spectral signature. This has been a problem in previous attempts to derive relations in the $\log (L)-\log (\sigma)$ as discussed by Bosch et al. (2002) when they were able to obtain photometry for individual knots within giant $\mathrm{H}$ II regions in M101.

\section{SUMMARY AND CONCLUSIONS}

From new high-resolution spectra of the H II regions NGC 7479 I, NGC 7479 II, NGC 7479 III, NGC6070 I, NGC6070 II and NGC 6070 IV obtained at the 100-inch du Pont Telescope, LCO, we have confirmed the giant nature of all these regions. We have also found that all of them show evidence of wing broadening evident mainly in the $\mathrm{H} \alpha$ line and confirmed in other emission lines. In five of them we are able to fit a broad component which explains the integral profile wings. Only in NGC 7479 II can we fit the integrated profile wings with two narrow components symmetrically shifted in velocity with respect to the average of the two intense components.

NGC 7479 I and NGC 7479 II reveal the presence of two separated kinematic components with relatively narrow profiles in all analysed emission lines. For NGC 7479 I region we can also generate $2 \mathrm{D}$ velocity images in $\mathrm{H} \alpha,\left[\mathrm{N}_{\mathrm{II}}\right] \lambda 6584 \AA$ and $\left[\mathrm{S}_{\mathrm{II}}\right] \lambda 6717 \AA$ lines. These images show that the two narrow components are spatially resolved and the kinematical information helps to split the knot in the velocity-distance plane. There is also evidence of the presence of a broad component in all the narrower extracted sections, at least in the $\mathrm{H} \alpha$ emission line. For NGC 7479 II region we can also fit two relatively narrow Gaussian components. In both regions the radial velocity average value of our components $A$ and $\mathrm{B}$ derived from the $\mathrm{H} \alpha$ emission line matches the global velocity in the galaxy when we project our value over the isovelocity contours in $\mathrm{H} \alpha$ velocity field map. A similar comparison, using the H I map yields a value much closer to the value measured for component $B$. Then, we could only suggest that component A shows an odd kinematic behaviour. New observations with better spatial and spectral resolution are needed to clarify this point.

In the rest of the studied $\mathrm{H}$ in regions, we find one narrow Gaussian component together with an underlying broad component, with no evidence of multiple narrow contributions. The radial velocity average derived for the narrower component corresponds to the one expected from galaxy rotation curves, within the observational errors, in all of these cases.

In most cases, the velocity dispersions of the broad components for these $\mathrm{H}_{\mathrm{II}}$ regions derived by optimal Gaussian fit are in agreement with Hägele et al. $(2009,2010)$ for circumnuclear star-forming regions with $\sigma_{\text {int }}$ in $\mathrm{H} \beta$ line $\sim 34$ to $65 \mathrm{~km} \mathrm{~s}^{-1}$, and those derived by Chu \& Kennicutt (1994) and Melnick et al. (1999) for 30 Doradus nebula with $\sigma_{\text {int }}$ in $\mathrm{H} \alpha$ line $\sim 45 \mathrm{~km} \mathrm{~s}^{-1}$.

The estimated offsets between the narrow and broad components in NGC 7479 III, NGC 6070 II and NGC 6070 IV are in complete agreement with the values found in NGC 2903 and NGC 3310 by Hägele et al. (2009, 2010), respectively, which are between -25 and $35 \mathrm{~km} \mathrm{~s}^{-1}$.

The distribution of the regions in the $\log (L)-\log (\sigma)$ plane are strongly dependent on the components derived from the profile fitting. Individual components have smaller fluxes and velocity dispersions than the global profile and points are therefore shifted in the diagram. In NGC 6070 the values derived from the global profile seem to lie, within observational errors, in the expected location if they follow the relation expected for virialized systems. When the individual components are plotted in the same diagram, only NGC 6070 II lies close to the regression, and NGC 6070 I and IV seem to be too luminous for their measured velocity dispersion. On the other hand, two out of three regions in NGC 7479 lie well away this regression if parameters are derived from a single Gaussian, but four out of five individual components show a very good agreement when plotted in the same diagram. Definitely, the presence of more than one Gaussian component rules the final position of the $\mathrm{H}$ II regions in the $\log (L)-\log (\sigma)$ plane.

\section{ACKNOWLEDGMENTS}

We are grateful to R. Terlevich for useful discussions and comments about the $2 \mathrm{D}$ velocity images that greatly improved the data analysis. We thank to C. Feinstein for providing us with the original data and images used for his published work and we are grateful to the director and staff of LCO for technical assistance and warm hospitality. Finally, we appreciate the comments and suggestions by the referee which significantly improved this paper. This research has made use of the NASA/IPAC Extragalactic Database (NED) which is operated by the Jet Propulsion Laboratory, California Institute of Technology, under contract with the National Aeronautics and Space Administration. 
Support from the Spanish MEC through grant AYA2007-67965C03-03 and from the Comunidad de Madrid under grant S0505/ESP/000237 (ASTROCAM) is acknowledged by GFH. VF and GB thank the Universidad Autónoma de Madrid, specially to Ángeles Díaz, for their hospitality.

\section{REFERENCES}

Arsenault R., Roy J., 1988, A\&A, 201, 199

Bohlin R. C., Dickinson M. E., Calzetti D., 2001, ApJ, 122, 2118

Bosch G., Terlevich E., Terlevich R., 2002, MNRAS, 329, 481

Chu Y. H., Kennicutt R. C. J., 1994, ApJ, 425, 720

de Vaucouleurs G., de Vaucouleurs A., Corwin H. G., Buta R. J., Paturel G., Fouque P., 1991, Third Reference Catalogue of Bright Galaxies, Vols 1-3. Springer-Verlag, Berlin

Devereux N. A., 1989, ApJ, 346, 126

Díaz A. I., Terlevich E., Pagel B. E. J., Víilchez J. M., Edmunds M. G., 1987, MNRAS, 226, 19

Díaz Á. I., Terlevich E., Castellanos M., Hägele G. F., 2007, MNRAS, 382, 251

Erwin P., Pohlen M., Beckman J. E., 2008, AJ, 135, 20

Feinstein C., 1997, ApJS, 112, 29

Firpo V., Bosch G., Morrell N., 2005, MNRAS, 356, 1357

Fuentes-Masip O., Muñoz-Tuñón C., Castañeda H. O., Tenorio-Tagle G., 2000, AJ, 120, 752

García-Gómez C., Athanassoula E., Barberà C., 2002, A\&A, 389, 68

García-Rojas J., Esteban C., Peimbert A., Peimbert M., Rodríguez M., Ruiz M. T., 2005, MNRAS, 362, 301

Grosbøl P., Patsis P. A., Pompei E., 2004, A\&A, 423, 849

Hägele G. F., 2008, PhD thesis, Universidad Autónoma de Madrid

Hägele G. F., Pérez-Montero E., Díaz A. I., Terlevich E., Terlevich R., 2006, MNRAS, 372, 293

Hägele G. F., Díaz Á. I., Cardaci M. V., Terlevich E., Terlevich R., 2007, MNRAS, 378, 163

Hägele G. F., Díaz A. I., Terlevich E., Terlevich R., Pérez-Montero E., Cardaci M. V., 2008, MNRAS, 383, 209

Hägele G. F., Díaz Á. I., Cardaci M. V., Terlevich E., Terlevich R., 2009, MNRAS, 396, 2295

Hägele G. F., Díaz Á. I., Cardaci M. V., Terlevich E., Terlevich R., 2010, MNRAS, 402, 1005

Haynes M. P., van Zee L., Hogg D. E., Roberts M. S., Maddalena R. J., 1998, AJ, 115, 62
Hippelein H. H., 1986, A\&A, 160, 374

Ho L. C., Filippenko A. V., Sargent W. L. W., 1997, ApJS, 112, 315

Homeier N. L., Gallagher J. S., 1999, ApJ, 522, 199

Keel W. C., 1983, ApJ, 269, 466

Laine S., 1996, PhD thesis, Univ. Florida

Laine S., 2001, Ap\&SS, 276, 667

Laine S., Gottesman S. T., 1998, MNRAS, 297, 1041

Laine S., Heller C. H., 1999, MNRAS, 308, 557

Márquez I., Masegosa J., Moles M., Varela J., Bettoni D., Galletta G., 2002, A\&A, 393, 389

Martinet L., Friedli D., 1997, A\&A, 323, 363

Medina Tanco G. A., Sabalisck N., Jatenco-Pereira V., Opher R., 1997, ApJ, 487, 163

Melnick J., Tenorio-Tagle G., Terlevich R., 1999, MNRAS, 302, 677

Mendez D. I., Esteban C., 1997, ApJ, 488, 652

Osterbrock D. E., Fulbright J. P., Martel A. R., Keane M. J., Trager S. C., Basri G., 1996, PASP, 108, 277

Pérez-Montero E., García-Benito R., Hägele G. F., Díaz A. I., 2010, MNRAS, doi:10.1111/j.1365-2966.2010.16421.x

Pohlen M., Trujillo I., 2006, A\&A, 454, 759

Quillen A. C., Frogel J. A., Kenney J. D. P., Pogge R. W., Depoy D. L., 1995, ApJ, 441, 549

Relaño M., Beckman J. E., 2005, A\&A, 430, 911

Rozas M., Zurita A., Heller C. H., Beckman J. E., 1999, A\&AS, 135, 145

Rozas M., Richer M. G., López J. A., Relaño M., Beckman J. E., 2006, A\&A, 455, 539

Saraiva M. F., Benedict G. F., 2003, A\&A, 409, 899

Smith M. G., Weedman D. W., 1970, ApJ, 160, 65

Springob C. M., Haynes M. P., Giovanelli R., Kent B. R., 2005, ApJS, 160, 149

Tenorio-Tagle G., Muñoz-Tuñón C., Cox D. P., 1993, ApJ, 418, 767

Terlevich R., Melnick J., 1981, MNRAS, 195, 839

Terlevich E., Díaz A. I., Terlevich R., González-Delgado R. M., Pérez E., García Vargas M. L., 1996, MNRAS, 279, 1219

Westmoquette M. S., Exter K. M., Smith L. J., Gallagher J. S., 2007a, MNRAS, 381, 894

Westmoquette M. S., Smith L. J., Gallagher J. S., Exter K. M., 2007b, MNRAS, 381, 913

This paper has been typeset from a $\mathrm{TE}_{\mathrm{E}} \mathrm{X} / \mathrm{LT} \mathrm{T} \mathrm{X}$ file prepared by the author. 
Capítulo 3

\section{Espectroscopía de alta resolución de la galaxia BCD Haro 15: Cinemática interna}

High resolution spectroscopy of the BCD galaxy Haro 15: I. Internal kinematics Firpo, V., Bosch, G., Hägele, G. F., Ángeles I. Díaz, and Morrell, N., 2011, MNRAS, aceptado

\subsection{Resumen de la publicación}

En este Capítulo, haciendo uso de espectroscopía échelle obtenida en el Observatorio Las Campanas, se presenta un estudio detallado de la cinemática interna del material nebular en múltiples brotes de formación estelar de la galaxia enana campacta azul Haro 15. Un análisis detallado de los complejos perfiles de líneas de emisión muestran la presencia de una componente ancha subyacente en casi todos los brotes, y la región de formación estelar más brillante muestra indudables signos de la presencia de dos componentes cinemáticas angostas diferentes. Estudiando la información que este análisis proporciona sobre el movíento de los brotes individuales en el potencial de la galaxia Haro 15, se confirma que siguen la rotación galáctica, aunque las componentes angostas del brote A tienen velocidades relativas demasiado grandes para ser explicada por rotación galáctica. Por último, se examina la relación entre la dispersión de velocidades y la luminosidad, encontrando que casi todos los brotes siguen la relación de sistemas virializados. Esto es válido para las componentes angostas identificadas en los perfiles complejos, en cambio los perfiles ajustados con una componente Gaussiana simple muestran una pendiente más plana. 


\subsection{Fundamentos básicos}

Durante años, varios estudios en diferentes frecuencias han sido llevados a cabo sobre la galaxia enana compacta azul Haro 15.

Desde el punto de vista morfológico, la imagen H $\alpha$ de Cairós et al. (2001) muestra que la galaxia presenta una compleja morfología resuelta en un gran número de brotes dispersos por toda la galaxia (ver Figura 1 de la publicación). Haro 15 ha sido clasificada como una galaxia peculiar (R)SB0 (de Vaucouleurs et al., 1991) y, de hecho, en las imágenes profundas tomadas con el telescopio de 2.2m CAHA se puede apreciar una morfología en espiral (López-Sánchez \& Esteban, 2008). López-Sanchez et al., (2010) encontraron una cinemática y abundancias químicas diferentes entre las regiones A y B lo cual podría estar indicando que la galaxia probablemente esté experimentando una fusión menor.

En la publicación se hace mención a que Haro 15 cumple con los criterios de una galaxia luminosa compacta azul (LCBGs, sigla en inglés de Luminous Compact Blue galaxies), y es que el nombre de estas galaxias fue asignado en Jangren et al., (2004) a las galaxias luminosas $\left(\mathrm{M}_{B}<-17.5\right)$, compactas $\left(\mu_{B} \leq 21.0 \mathrm{mag} \operatorname{arcsec}^{2}\right)$ y azules $(\mathrm{B}-\mathrm{V} \leq 0.6)$ las cuales están sometidas a un importante estallido estelar. Esta definición intenta incluir las galaxias BCGs locales más luminosas, como así tambíen a una variada familia de brotes de formación estelar a redshifts intermedios. Generalmente, estos objetos son poblaciones aisladas de alto brillo superficial pudiendo ser observados a altos redshifts y tienen propiedades muy similares a las regiones de formación estelar de alta luminosidad en las galaxias H ir (Hoyos et al., 2004).

Como se vio en el Capítulo anterior, la espectroscopía échelle proporciona un medio para buscar componentes cinemáticamente diferentes en las líneas de emisión del gas ionizado, ya que llega a la resolución espectral necesaria para resolver la presencia de estructuras en el perfil de líneas de emisión, generalmente enmascarados por el gran ancho supersónico y la baja resolución espectral instrumental.

En el Capítulo 2 (Firpo et al., 2010) se observó que al hacer un ajuste Gaussiano simple en el perfil de la línea, existe un residuo presente en las alas del perfil. Basado en la literatura, y siempre que fuera posible, se evaluó la posible presencia de una componente ancha o dos componentes simétricas a ambos lados de la componente angosta en el ajuste de los anchos de las emisiones observadas. En el presente trabajo, también se ha encontrado que todas las regiones de la galaxia Haro 15 muestran este ensanchamiento siendo más evidente en el perfil de la línea $\mathrm{H} \alpha$ y luego se confirma en el resto de las líneas de emisión. Por otro lado, se analiza la relación entre la dispersión de velocidades en la línea $\mathrm{H} \alpha$ y su luminosidad estudiando cómo repercute la existencia de diferentes componentes cinemáticas en el plano $\mathrm{L}(\mathrm{H} \alpha)$ vs. $\sigma$.

En este Capítulo se presenta espectroscopía échelle obtenida con el telescopio de 100" du Pont, del Observatorio Las Campanas (LCO), en cinco brotes de formación estelar de Haro 15 con una resolución en velocidad de $12 \mathrm{~km} \mathrm{~s}^{-1}$. Esta resolución permite la identificación de las diferentes componentes cinemáticas del gas y la medición de sus correspondientes dispersiones 
de velocidades. La identificación de los brotes sigue la nomenclatura utilizada por Cairós et al., (2001). Dos brotes más fueron observados en este trabajo, a los cuales se los ha denominado E y F, continuando la notación de Cairós.

Este estudio forma parte de un proyecto en el que, con la obtención de datos de alta resolución espectral échelle, se determina la naturaleza de las Regiones H in Gigantes visibles desde el hemisferio sur y se analizan, además, las condiciones físicas del gas ionizado de las regiones en esta galaxia enana compacta azul. En la publicación a continuación se presentan las observaciones y la reducción de los datos en la Sección OBSERvations And REDUCtions; en la Sección Results And Discussion se presenta el análisis de los perfiles de la línea de emisión y se analizan los resultados de cada brote individual. Además se estudian las velocidades radiales y se analiza el impacto que tiene la presencia de varias componentes sobre la ubicación de cada región H II en el plano $\log (L)-\log (\sigma)$; por último se incluye resumen y conclusiones del trabajo en la Sección nombrada como SummarY.

\subsection{Herramientas utilizadas}

Los espectros alta resolución de Haro 15 se obtuvieron utilizando el espectrógrafo échelle del telescopio de 100" du Pont, del Observatorio Las Campanas (LCO), Chile, en julio del 2006. El rango espectral cubierto por las observaciones fue de $\lambda 3400$ a $\lambda 10000 \AA$. Las condiciones de observación fueron buenas, con un seeing de 1 segundo de arco. Se aplicó un binning $2 \times 2$ al CCD el cual tiene una resolución espacial de 0.259 " $\mathrm{px}^{-1}$. La ranura utilizada tenía un ancho de 1" y una longitud de 4". Considerando que las exposiciones son largas, la resolución espacial esta limitada no solo por seeing sino también por el guiado, y teniendo en cuenta la distancia a Haro 15, la escala espacial de los espectros nos dice que la menor estructura que se puede ver es de al menos $0.43 \mathrm{kpc}$. La resolución espectral alcanzada en los espectros échelle es de $\mathrm{R} \simeq 25000: \Delta \lambda=0.25 \AA$ a los $\lambda 6000 \AA$, medida a partir del ancho a potencia mitad (FWHM) de las líneas de la lámpara de comparación de Thorio-Argón. Esto se traduce en una resolución de $\sim 12 \mathrm{~km} \mathrm{~s}^{-1}$.

El tiempo de exposición para cada región fue 1800 segundos. También se observó para la calibración en flujo una estrella estándar espectrofotométrica, Feige 110, con un tiempo de exposición de 1200 segundos. Además, durante todas las noches se tomaron espectros de lámpara de comparación Th-Ar, Milky Flats (flats de cielo obtenidos con un difusor durante la tarde), y bias.

El análisis de los datos se realizó con el software $\operatorname{IRAF}^{1}$. Luego de la resta de bias, correcciones por flat fields con los Milky Flats, las imágenes bidimensionales fueron corrigidas por rayos cósmicos con la tarea cosmicrays de IRAF, la cual detecta y elimina los rayos cósmicos con un algoritmo de cociente de flujos. Los datos corregidos se redujeron con las

\footnotetext{
${ }^{1}$ Image Reduction and Analysis Facility, distribuido por NOAO, operado por AURA, Inc., bajo contrato con NSF.
} 
rutinas de IRAF siguiendo el mismo procedimiento descrito en Firpo et al., (2005).

\subsection{Metodología en la cinemática}

En el espectro échelle calibrado, se cortó el rango de longitud de onda en una dada línea de emisión y este ha sido transformado al plano de velocidad aplicando la corrección Doppler. Midiendo la velocidad central (longitud de onda) y el ancho en varias líneas de emisión se han determinado las velocidades radiales y la dispersión de velocidades del gas ionizado en las diferentes regiones de formación estelar. La dispersión de velocidades intrínseca $\left(\sigma_{\text {int }}\right)$, fue corregida por las contribuciones instrumental y térmica de cada línea de emisión. Los pequeños cambios en las temperaturas electrónicas, de unos pocos cientos de grados, no modifican sustancialmente esta corrección, como ya se ha discutido en el Capítulo anterior (Firpo et al., 2010). En el Capítulo 4 se presentará un tratamiento detallado en la determinación de temperaturas y densidades electrónicas de cada uno de estos objetos.

Como fue comentado en el Capítulo anterior, en el presente Capítulo los brotes de formación estelar de la galaxia BCD, Haro 15, muestran evidencias de residuo presente en las alas de las emisiones, el cual es observado en todas las líneas de emisión. Haciendo uso del proceso iterativo, explicado en Firpo et al., (2010), para el ajuste de múltiples componentes Gaussianas en el perfil de línea, se evaluó la presencia de una componente ancha y la presencia de más de una componente angosta. En este caso, se ha podido ajustar una variada gama de componentes, explicando así las alas del perfil integrado en cada una de las regiones.

Todas las regiones, a excepción del brote F, muestran múltiples componentes supersónicas. En el brote $\mathrm{F}$ el ensanchamiento del perfil integrado solamente pudo ser detectado en la línea $\mathrm{H} \alpha$. En esta línea de emisión se pudo ajustar una componente ancha supersónica y una angosta subsónica de $8 \mathrm{~km} \mathrm{~s}^{-1}$, dispersión de velocidades típica de regiones H II clásicas, aunque la presencia de una componente ancha sea casi exclusiva de las Regiones H II Gigantes.

En la publicación se discuten los resultados agrupándolos según los resultados de los perfiles y por brote. Este trabajo ha sido aceptado el día $1^{\text {ro }}$ de marzo de 2011 para su publicación en la revista internacional con referato Monthly Notices of the Royal Astronomical Society. 
Mon. Not. R. Astron. Soc. 000, 000-000 (0000) Printed 3 March $2011 \quad$ (MN LATEX style file v2.2)

\title{
High resolution spectroscopy of the BCD galaxy Haro 15: I. Internal kinematics
}

\author{
Verónica Firpo $^{1 \star}$, Guillermo Bosch ${ }^{1} \dagger$, Guillermo F. Hägele ${ }^{1,2} \ddagger$ \\ Ángeles I. Díaz ${ }^{2}$ and Nidia Morrell ${ }^{3}$ \\ ${ }^{1}$ Facultad de Ciencias Astronómicas y Geofísicas, Universidad Nacional de la La Plata, Paseo del Bosque s/n, 1900 La Plata, Argentina. \\ 2 Departamento de Física Teórica, C-XI, Univerdidad Autónoma de Madrid, 28049 Madrid, Spain. \\ ${ }^{3}$ Las Campanas Observatory, Carnegie Observatories, Casilla 601, La Serena, Chile.
}

Accepted . Received ; in original form

\begin{abstract}
Using echelle spectroscopy, obtained at Las Campanas Observatory, we present a detailed study of the internal kinematics of the nebular material in multiple knots of the blue compact dwarf galaxy Haro 15. A detailed analysis of the complex emission line profiles show the presence of an underlying broad component in almost all knots, and the brightest star-forming region shows unmistakable signs for the presence of two distinct narrow kinematical components. We also study the information that our analysis provides regarding the motion of the individual knots in the Haro 15 galaxy potential, confirming that they follow galactic rotation. Finally, we examine the relation between their velocity dispersion and luminosity, finding that almost all knots follow the relation for virialised systems. This holds for the strong narrow components identified in complex fits and for single profile fits, although the latter show a flatter slope. In agreement with previous findings, in this paper we show that the existence of multiple kinematical components among massive starbursts cannot be overlooked, as it has a noticeable effect on any subsequent analysis that relies on basic parameters.
\end{abstract}

Key words: (ISM:) H II Regions - galaxies: starburst - galaxies: individual: Haro 15 $-$

\section{INTRODUCTION}

Already in the original list of blue galaxies with emission lines by Haro (1956) who described this object as "minute cometary nebula", Haro 15 has later been included in several compilations of Blue Compact Galaxies (BCG). Several studied at all frequencies have been carried out over this object. In particular, the optical spectroscopy was analysed by Hunter \& Gallagher (1985); Mazzarella et al. (1991); Kong et al. (2002); Shi et al. (2005), between others. Owing to the detection of the He II $\lambda 4686$ emission line by Kovo \& Contini (1999), Schaerer et al. (1999) has classified this galaxy as a Wolf-Rayet (WR) galaxy. López-Sánchez \& Esteban (2010) also found a blue WR bump supporting the WR nature of Haro 15. The H $\alpha$ image shown in Cairós et al. (2001) shows a knotty morphology with the starburst region resolved in a large number of clumps which appear scattered over the entire galaxy. The integrated $\mathrm{H} \alpha$ luminosity yields a star formation rate $(\mathrm{SFR})$ of $3.3 \mathrm{M}_{\odot} \mathrm{yr}^{-1}$ (López-Sánchez

\footnotetext{
* vfirpo@fcaglp.unlp.edu.ar

† IALP-CONICET, Argentina.

$\ddagger$ CONICET, Argentina.
}

\& Esteban 2008). López-Sánchez (2010) analysed the SFR in Haro 15 using multi-wavelength data. The derived values using $\mathrm{H} \alpha$, FIR (far-infrared) and radio data are very similar, but the value derived using the FUV (far-ultraviolet) luminosity is twice the others, confirming that a young stellar population is dominating the light of the galaxy and suggesting that the starburst phenomenon in Haro 15 started some time ago (at least, $100 \mathrm{Myr}$ ago). From the morphological point of view, Haro 15 has been classified as an (R)SB0 peculiar galaxy by de Vaucouleurs et al. (1991) and in fact, in the deep images taken with the 2.2m CAHA telescope shown in López-Sánchez \& Esteban (2008), the spiral morphology of the galaxy can easily be appreciated. Two high surface brightness concentrations can be distinguished, named A and $\mathrm{C}$ by the authors. Both show blue colours and high FUV emission, indicative of recent and on-going star formation activity, further supported by the presence of the WR features.

Long slit optical spectroscopy of Haro 15 has been presented in López-Sánchez \& Esteban (2009) covering four main regions in the galaxy: the center (named $\mathrm{C}$ by the authors) and three bright regions located ESE (named A), 
WNW (named D) and NE (named B). The spectrum of the central region shows strong nebular emission lines and prominent stellar absorption wings in the Hi Balmer lines, evidence of an underlying stellar population which the authors estimate to be around 500 Myr old. Only emission lines are seen in regions $\mathrm{A}$ and $\mathrm{B}$ and the spectrum of region $\mathrm{D}$ results too noisy to be analysed. These authors derived an oxygen abundance of $12+\log (\mathrm{O} / \mathrm{H})=8.37 \pm 0.10$ and $8.10 \pm 0.06$ for regions $\mathrm{A}$ and $\mathrm{B}$, respectively. Based on these data the authors conclude that all the observed knots can be classified as typical Hiı regions.

Haro 15 has an absolute magnitude $\mathrm{M}_{B}=-20.69$, a surface brightness $\mu_{B}=18.56 \mathrm{mag} \operatorname{arcsec}^{-2}$ and a colour B-V= 0.33 (Cairós et al. 2001). At a distance of 86.6 Mpc (de Vaucouleurs et al. 1991), Haro 15 meets the criteria for a Luminous Compact Blue Galaxy (LCBG) (Hoyos et al. 2004) despite the fact of its brightness distribution showing an exponential profile with a scale length of $1.37 \mathrm{kpc}$. The nature of this type of galaxies is not yet clear since they probably constitute a mixed population of starburst galaxies. Some authors suggest that LCBGs might represent the final outcome of a merger between a dwarf elliptical and a gas rich dwarf galaxy or Hi cloud (Östlin 1998; Cumming et al. 2008). The interactions taking place during the merging process would act as the starburst trigger (see e.g. López-Sánchez et al. 2004, 2006). The images of Haro 15 showing two separated nuclei surrounded by a more regular, roughly elliptical envelope with twisted isophotes, together with different features and faint extensions as reported by Cairós et al. (2001) give support to this picture. Other galaxy properties like different kinematics and chemical abundances between regions A and B may also indicate that Haro 15 is probably experiencing a minor merger (López-Sánchez 2010). On the other hand, a reliable determination of the mass of this kind of objects is needed in order to decide on the evolutionary path they may follow: becoming dwarf spheroidal galaxies (Hoyos et al. 2007) or the bulges of small spirals (Hammer et al. 2001). However, interactions and mergers, as well as feedback processes result of intense star formation, might reflect in a peculiar gas kinematics that prevent the derivation of their dynamical masses from the gas velocity widths.

Echelle spectroscopy provides a means to look for kinematically different components in the emission lines of the ionised gas since it reaches the spectral resolution needed to resolve the presence of structures within the emissionline profile, usually masked by its large supersonic width. In Firpo et al. (2010) we observed a residual present in the wings of several lines when fitting a single Gaussian profiles to the emission lines observed in the Giant Hir Regions within the galaxies NGC 7479 and NGC 6070. Basing on the variety studies that have been proposed in the literature to interpret the existence of the broad supersonic component measured in the emission line profile of Giant Hı Regions, and whenever possible, we have evaluated the possible presence of a broad component (Muñoz-Tuñón et al. 1996; Melnick et al. 1999; Hägele et al. 2007, 2009, 2010, among others) or two symmetric low-intensity components in the fit to the observed emission line profile widths (Chu \& Kennicutt 1994; Relaño \& Beckman 2005; Rozas et al. 2006). In the present work, we have also found that all Haro 15 regions show evidence of wing broadening evident mainly in the $\mathrm{H} \alpha$ line and confirmed in other emission lines. Another common
Figure 1. Finding chart for the Giant HiI Region candidates observed in Haro 15, identified by circles and labelled following Cairós et al. (2001). Wide Field Planetary Camera $2 \mathrm{H} \alpha$ image was obtained from the Multimission Archive at the Space Telescope Science Institute (MAST)

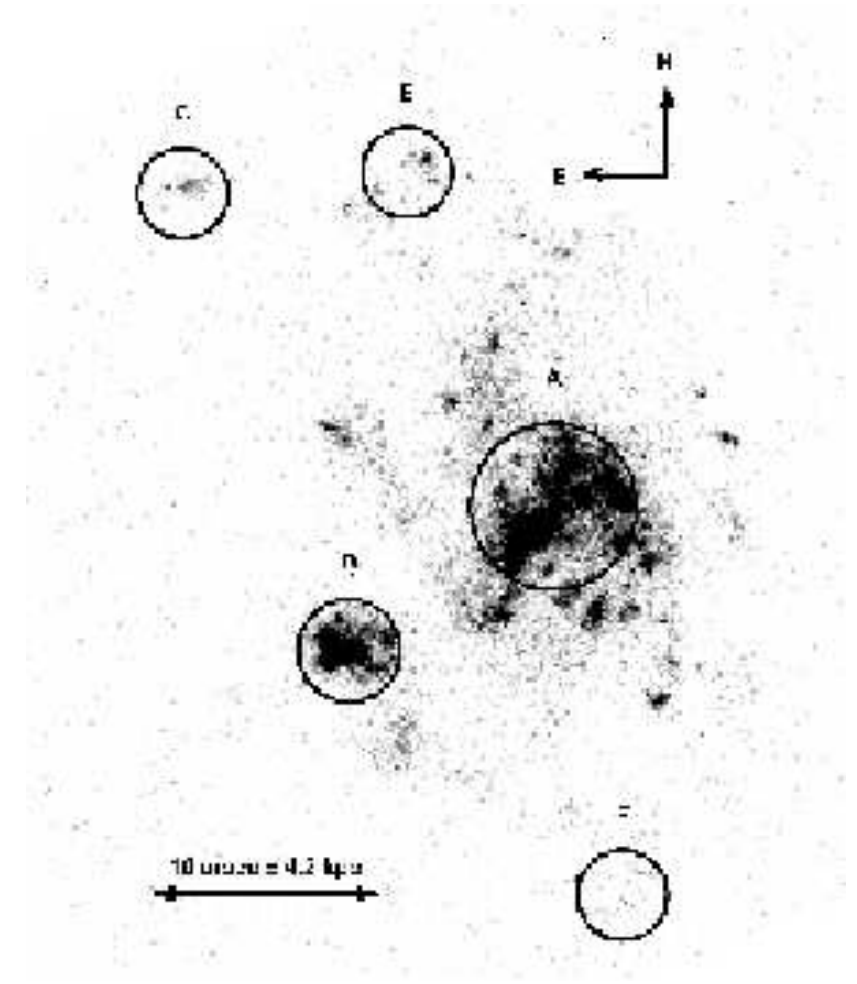

feature of Giant His Regions is the supersonic width of their emission line profiles, although the origin of these velocities is not yet clear (Terlevich \& Melnick 1981; Roy et al. 1986; Hippelein 1986). A relation between $\mathrm{H} \alpha$ luminosity and velocity dispersion of the form $\mathrm{L}(\mathrm{H} \alpha) \propto \sigma^{4}$ is expected under the assumption of a gravitational origin of the ionised gas dynamics. Therefore, a study of the implications that the existence of several kinematically distinct components has on the $\mathrm{L}(\mathrm{H} \alpha)$ vs. $\sigma$ relation is of great value.

In this paper we present echelle spectroscopy obtained with the 100-inch du Pont Telescope at Las Campanas Observatory (LCO) of five different positions across Haro 15 which provide a velocity resolution of about $12 \mathrm{kms}^{-1}$ allowing the identification of different kinematical components of the gas and the measurement of their corresponding velocity dispersions. This study is part of a project to obtain high spectral resolution echelle data to determine the nature of Giant Hı Regions visible from the southern hemisphere and analyse the physical conditions of the ionised gas of these regions and Blue Compact Dwarf galaxies. In Section 2 we present the observations and the data reduction. Section 3 presents the analysis of the emission-line profiles and discusses the results. Finally, the summary and conclusions of this work are given in Section 4. 
Table 1. Journal of observations. The identifications in the first column correspond to the nomenclature used in this paper, following and extending that in Cairós et al. (2001); columns 2 and 3 list the observation date and the air mass respectively; columns 4 and 5 show the distance to the galactic center in arcsecs and $\mathrm{kpc}$, respectivey; finally, column 5 lists the identification of the regions given in López-Sánchez \& Esteban (2008) referred to as LS notation. The exposure time for each region was 1800 seconds.

\begin{tabular}{cccccc}
\hline Knots & Date & sec z & Dist.(") & Dist.(kpc) & LS \\
\hline Haro 15 A & 2006 Jul 19 & 1.2 & 0 & 0 & $\mathrm{C}$ \\
Haro 15 B & 2006 Jul 19 & 1.1 & 11 & 4.62 & $\mathrm{~A}$ \\
Haro 15 C & 2006 Jul 19 & 1.1 & 20 & 8.4 & $\mathrm{~B}$ \\
Haro 15 E & 2006 Jul 20 & 1.2 & 16 & 6.72 & $\ldots$ \\
Haro 15 F & 2006 Jul 20 & 1.1 & 17 & 7.14 & $\ldots$ \\
\hline
\end{tabular}

\section{OBSERVATIONS AND DATA REDUCTION}

High resolution spectroscopy of Haro 15 was obtained using an echelle spectrograph attached to the 100-inch du Pont Telescope, Las Campanas Observatory (LCO), in July 19 and 20 of 2006 . The spectral range covered by the observations was from 3400 to $10000 \AA$. Observing conditions were good, with an average of 1 arcsec seeing and photometric nights. A $2 \times 2$ binning was applied to the $\mathrm{CCD}$ in order to minimise the readout contribution to the final spectrum noise. With 1 arcsec effective slit width and 4 arcsec slit length, the spectral resolution achieved in our du Pont Echelle data was $\mathrm{R} \simeq 25000: \Delta \lambda=0.25 \AA$ at $\lambda 6000 \AA$, as measured from the FWHM of the ThAr comparison lines taken for wavelength calibration purposes. This translates into a velocity resolution of $\sim 12 \mathrm{kms}^{-1}$.

Considering the distance to Haro 15 and that the spatial resolution is limited by seeing, the smallest structure that can be resolved is $0.43 \mathrm{kpc}(\sim 1 " \sim 1.93$ pixel $)$

Five different regions in Haro 15 were observed as shown in Figure 1. The spectra were obtaind as singles exposures of 1800 seconds. CALSPEC spectrophotometric standard star Feige 110 (Bohlin et al. 2001) was also observed for flux calibration purposes with an exposure time of 1200 seconds. In addition, Th-Ar comparison spectra, milky flats (sky flats obtained with a diffuser, during the afternoon) and bias frames were taken every night. A journal of observations is shown in Table 1.

The data analysis was carried out using the $\operatorname{IRAF}^{1}$ software. After bias subtraction and flat field corrections by means of milky flats the bidimensional images were corrected for cosmic rays using the task COSMICRAYS which detects and removes cosmic rays using a flux ratio algorithm. The corrected data were reduced by IRAF routines following procedures similar to those described in Firpo et al. (2005).

At the end of the process, we compared the red end of the wavelength calibrated spectra with the night-sky spectrum by Osterbrock et al. (1996). This turned out to be a very reliable confirmation of the goodness of the wavelength solution, and we checked that differences between our wavelengths and the sky line wavelengths were below $0.04 \AA$.

1 Image Reduction and Analysis Facility, distributed by NOAO, operated by AURA, Inc., under agreement with NSF.
Flux calibration was achieved by observing the CALSPEC spectrophotometric standard star, Feige 110 (Bohlin et al. 2001) whose flux was tabulated every $2 \AA$. Despite its relatively low brightness $(\mathrm{V}=11.83)$, Feige 110 is ideal for calibrating high resolution echelle spectra. The amount of defined intervals within an echelle order ranged from four to twelve, depending on the quality of the spectrum. The flux calibrations was performed as described in Firpo et al. (2005).

\section{RESULTS AND DISCUSSION}

\subsection{Line profile analysis}

We identified the hydrogen recombination lines, such as $\mathrm{H} \alpha$ and $\mathrm{H} \beta$, and collisionally excited lines, such as [N II] $\lambda \lambda 6548,6584$, [S II] $\lambda \lambda 6717,6731$ present in the spectra, making use of the known redshift, $\mathrm{z}=0.021371$, for Haro 15 (de Vaucouleurs et al. 1991). The strong lines were used to analyse the structure of velocity profiles as they allow us to verify the existence of more than one component as described in Firpo et al. (2010). The adopted laboratory wavelengths were taken from the work of García-Rojas et al. (2005).

From the echelle calibrated spectrum, we cut the wavelength range where a given emission line is and we transformed from wavelength to velocity plane using the Doppler correction. By measuring the central velocity (wavelength) and width of several emission lines we determine the radial velocities and velocity dispersions of the ionised gas in the differents star-forming regions of Haro 15. The radial velocity and the intrinsic velocity dispersion $\left(\sigma_{\mathrm{int}}\right)$, corrected for the instrumental and thermal contributions of each emission line, are also derived. For these observations we consider $\sigma_{i}=5.2 \mathrm{kms}^{-1}$ as instrumental width. The thermal contribution was derived from the Boltzmann's equation $\left(\sigma_{t}=2 \mathrm{kT} / \mathrm{m}_{a}\right)$, where $k$ is the Boltzmann's constant, $T$ the kinetic temperature $\left(T \simeq 10^{4} K\right)$ and $m_{a}$ the atomic mass of the corresponding element. Although a detailed determination of the electron density and temperatures, and chemical ionic and total abundances for each region will be presented in Hägele et al. (2011, in prep., hereafter Paper II), small changes of a few hundred degrees do not noticeably modify this correction, as previously discussed in Firpo et al. (2010). The fluxes were derived from the amplitude (A) and the FWHM of the Gaussian profile obtained in the component fitting $(\mathrm{F}=1.0645 \times \mathrm{A} \times \mathrm{FWHM})$, and the corresponding errors were estimated taking into account the errors in these two parameters.

As already reported by Firpo and collaborators, in the present work we have also found that all Haro 15 emission knots show evidence of wing broadening, which is always found in the $\mathrm{H} \alpha$ line profiles and it is usually also observed in the profiles of the bright emission lines. Making use of the iterative fitting of multiple Gaussian profiles we evaluated the presence of a broad component and more than one narrow component present in the emission line profile. In this case, we fitted a broad component, explaining the integral profile wings for all regions.

In the following subsections we will discuss our findings for each knot resulting from the profile fits. 
Haro 15 A

In our high resolution spectra Haro $15 \mathrm{~A}$ shows a complex structure which, although evident in radial velocity space, could not be spatially resolved.

We identified and fitted Gaussian profiles to the $\mathrm{H} \beta$, [O III] $\lambda 5007,[\mathrm{~N} \mathrm{II}] \lambda 6548, \mathrm{H} \alpha,[\mathrm{N}$ II] $\lambda 6584$ and [S II] $\lambda \lambda 6717$ lines in this knot with NGAUSSFIT routines. The Gaussian fits of these emission line profiles are shown in Figures 2 and 3. The Gaussian fits in the profiles reveal the presence of two distinctly separated kinematical components labelled narrow 1 and 2 (n1 and n2). Component n1 shows a profile slightly broader than component $\mathrm{n} 2,\left(\sigma_{\text {int }} \simeq 28\right.$ and 24 $\mathrm{km} \mathrm{s}^{-1}$, respectively) and both components show a relatively large spread in individual radial velocities among the different emission lines present in the spectrum. The reliability of these values is confirmed when we improve the profile fitting using NGAUSSFIT which in turn yields values for the profile width of each component. It is worth noting that, although the profile fitting to the [O III] lines shows similar overall results, the $\mathrm{n} 2$ components show the broader profile, opposite to what is found for the other emission lines. This could be related to a different kinematic behaviour of the highly ionised gas, although this needs to be confirmed for other high excitation lines.

Always considering the presence of two distinct components with different radial velocities, the overall fit continues showing the presence of a residual in the emission line wings. Following the procedures outlined in Firpo et al. (2010), we are able to fit a broad component, with a velocity dispersion of about $78 \mathrm{~km} \mathrm{~s}^{-1}$ from the $\mathrm{H} \alpha$ emission line and slightly lower from the rest of the lines. Table 2 shows the parameters for the three components that fit the global profile. Individual Gaussian component fluxes are listed as fractional emission measures $\left(\mathrm{EM}_{f}\right)$ relative to the total line flux following the work by Relaño \& Beckman (2005). The sum of these individual fluxes, which we will hereafter refer to as overall $\mathrm{H} \alpha$ flux, uncorrected for reddening, is found to be $(5.49 \pm 0.05) \times 10^{-14} \mathrm{erg} \mathrm{s}^{-1} \mathrm{~cm}^{-2}$. In Figure 2 we show the NGAUSSFIT fitting done with three different Gaussian components in the emission lines which have enough signal to provide a reliable fit. The validity of the profile multiplicity and broadening is checked over the different emission lines, becoming more evident for the strongest emission lines. Figure 3 shows the excellent agreement among individual fits for the most intense emission lines in Knot A.

The top panel in Figure 4 shows the spatial profile of the $\mathrm{H} \alpha$ emission line in knot A. Two distinct zones are clearly distinguished, separated by 1.72 arcsec $\sim 0.72 \mathrm{kpc}$. We have performed additional extractions of these two zones (labelled A I and A II) individually. Inspection of the individual plots displayed in the bottom panels show that the kinematical structure is dominated by region A I, somewhat expected as it is brighter than region A II, which exhibits a more simple emission profile in turn. High spatial resolution integrated field spectroscopy is needed to disentangle this complex behaviour.

\section{Haro 15 B}

The spectrum of region $\mathrm{B}$ is dominated by nebular emission lines, where we detected and measured [O III] $\lambda 4363$ and
He II $\lambda 4686$. We identified and fitted Gaussian profiles to the $\mathrm{H} \beta$, [O III] $\lambda \lambda 4959,5007$, [N II] $\lambda 6548, \mathrm{H} \alpha$, [N II] $\lambda 6584$ and $[\mathrm{S} \mathrm{II}] \lambda \lambda 6717,6731$ lines in this region using NGAUSSFIT. It is interesting to note that, although from inspection of the Wide Field Planetary Camera 2 image shown in Figure 1 , a complex structure of region B is apparent, this is not reflected in the kinematical behaviour of the region, since it is possible to fit a single Gaussian component with a velocity dispersion of $20 \mathrm{~km} \mathrm{~s}^{-1}$. Nevertheless, the profile fittings show the presence of a residual in the emission line wings that we were able to explain by fitting a broad component with a velocity dispersion of about $43 \mathrm{kms}^{-1}$ Results of the fitting procedure can be seen in Figure 5; it is worth noting that the logarithmic scale chosen for the $y$-axis magnifies the $1 \%$ residual in the profile wings for $\mathrm{H} \alpha$ and [O III] $\lambda 5007$. For the listed lines the derived radial velocities, velocity dispersions and their corresponding errors are listed in Table 2. The overall $\mathrm{H} \alpha$ flux, uncorrected for reddening, is found to be $(9.88 \pm 0.3) \times 10^{-14} \mathrm{erg} \mathrm{s}^{-1} \mathrm{~cm}^{-2}$.

As concluded by López-Sánchez \& Esteban (2009), knot $B$ has a much higher ionization degree than the rest of the regions in Haro 15. These authors suggest that this may be a consequence of the extreme youth of this knot. This fact and the low metallicity found in knot B (lower than for the other regions) indicate that it has a different nature, probably being the remnant of a dwarf galaxy which is experiencing a minor interaction with Haro 15 (López-Sánchez 2010).

\section{Haro $15 C$}

Although the observed spectrum of region $\mathrm{C}$ is faint, we were able to identify and fit Gaussian profiles to the $\mathrm{H} \beta$, [O III] $\lambda 5007, \mathrm{H} \alpha,[\mathrm{N} \mathrm{II}] \lambda 6584$ and [S II] $\lambda \lambda 6717,6731$ lines. Knot $\mathrm{C}$ shows one narrow component together with the underlying broad component. However, due to the poor signal of the spectrum, all emission lines were fitted using the $\mathrm{H} \alpha$ NGAUSSFIT solution as a template, fixing the profile centers and widths, and only allowing the task to fit the profile amplitudes. In Figure 6 we only show $\mathrm{H} \alpha$ since the rest of the intense lines are very noisy due to the low signal-to-noise ratio of the spectrum. Table 3 shows the derived kinematical parameters. The overall $\mathrm{H} \alpha$ flux, uncorrected for reddening is $(2.67 \pm 0.07) \times 10^{-15} \mathrm{erg} \mathrm{s}^{-1} \mathrm{~cm}^{-2}$.

\section{Haro 15 E}

We detect the presence of a broad profile, suggesting the presence of a double peak together with a flux excess in the strongest emission lines. We identified and fitted Gaussian profiles to the $\mathrm{H} \beta,[\mathrm{O}$ III] $\lambda 5007, \mathrm{H} \alpha$, [N II] $\lambda 6584$ and [S II] $\lambda \lambda 6717,6731$ lines. The results of the profile fitting procedure yields two components of similar width. Although both are supersonic profiles it is not possible to distinguish a broad and narrow component and therefore refer to the identified components as narrow 1 and 2 (see Figure 6). For the listed lines the derived radial velocities, the velocity dispersions and the corresponding errors are listed in Table 3. The overall $\mathrm{H} \alpha$ flux, uncorrected for reddening, is found to be $(4.99 \pm 0.14) \times 10^{-15} \mathrm{erg} \mathrm{s}^{-1} \mathrm{~cm}^{-2}$.

Owing to the poor signal-to-noise spectrum we fitted some of the emission lines such as [N II] $\lambda 6584$ and 
Figure 2. Strongest emission lines from Haro 15 A spectrum. Each panel includes flux calibrated spectrum, where the individual x-axis have been normalised to the observed radial velocity for comparison purposes. To enhance details at low luminosity levels, the y axes are shown in logarithmic scale. From top to bottom and left to right: $\mathrm{H} \beta$, [O III] $\lambda 5007, \mathrm{H} \alpha$, [N II] $\lambda 6584$ and [S II] $\lambda 6717$.
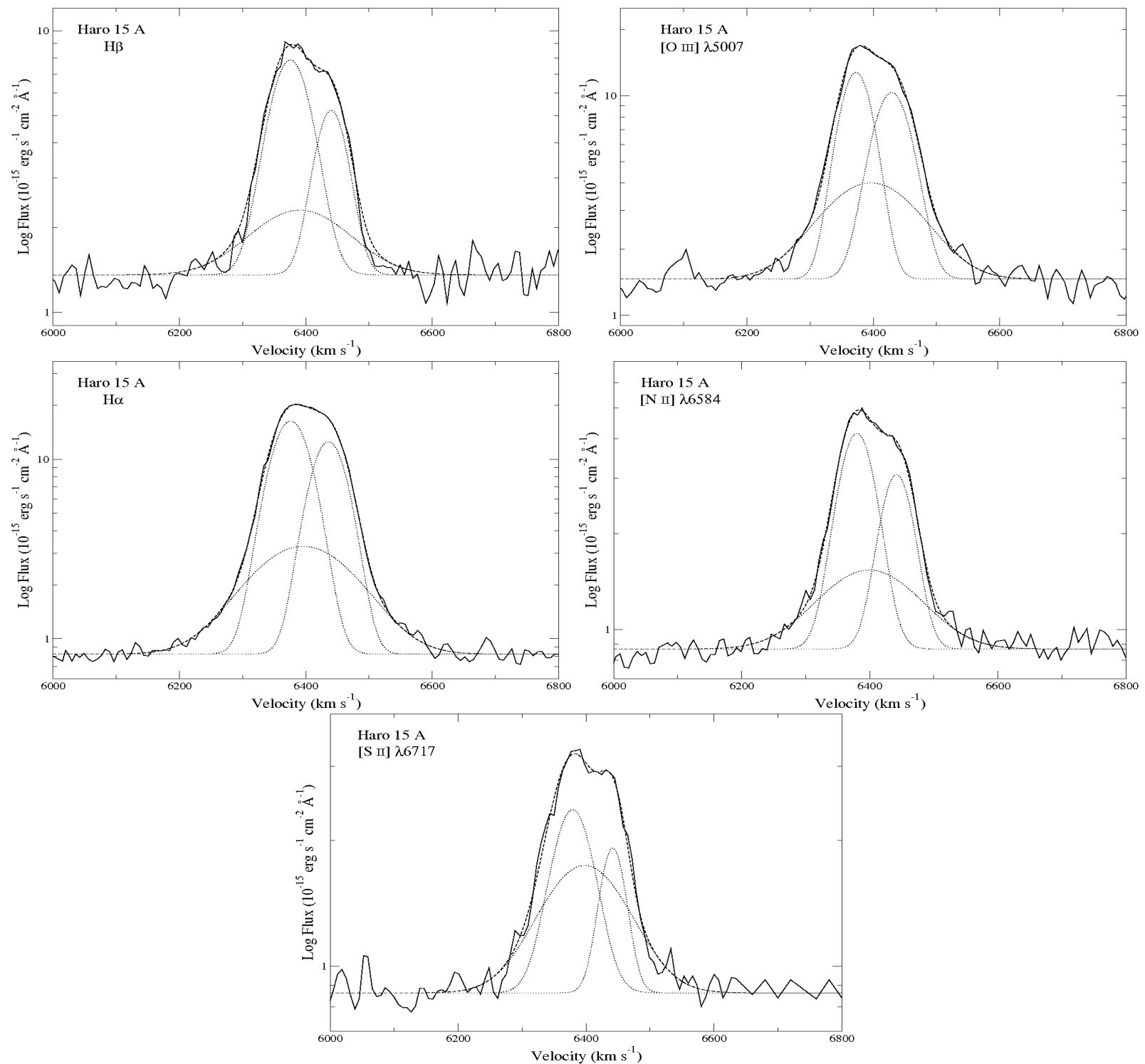

[S II] $\lambda \lambda 6717,6731$, using the $\mathrm{H} \alpha$ NGAUSSFIT solution, and iterating separately for individual set of parameters, following the procedure described in Firpo et al. (2010) .

\section{Haro 15 F}

The observed spectrum of knot $\mathrm{F}$ is the weakest one, and hence we only identified and fitted the Gaussian profiles of the $\mathrm{H} \beta$, [O III $] \lambda 5007$, and $\mathrm{H} \alpha$ lines. $\mathrm{H} \beta$ and [O III $] \lambda 5007$ are in fact very noisy and narrow, rendering impossible the task of fitting multiple Gaussian components (narrow plus broad). The spectral line broadening in their integrated spectra is only observed in the $\mathrm{H} \alpha$ line where we could fit a narrow Gaussian component together with the broad one, with velocity dispersions of about $8.3 \mathrm{~km} \mathrm{~s}^{-1}$ and 22 $\mathrm{km} \mathrm{s}^{-1}$, respectively (see Figure 6). The estimated velocity dispersion for the narrow component in the $\mathrm{H} \alpha$ line is sub- sonic $\left(8 \mathrm{~km} \mathrm{~s}^{-1}\right)$, typical of classic HiI regions, although the presence of a broad component is almost exclusive of Giant HiI Regions.

For $\mathrm{H} \alpha$, the derived radial velocity, the velocity dispersions and the corresponding errors are listed in Table 3. The overall $\mathrm{H} \alpha$ flux, uncorrected for reddening, is found to be $(1.06 \pm 0.16) \times 10^{-15} \mathrm{erg} \mathrm{s}^{-1} \mathrm{~cm}^{-2}$.

\subsection{Radial Velocities}

The radial velocities for each component of the different knots of Haro 15 are given in the corresponding tables where the results for the profile fits are shown. In Table 4 we list the average radial velocity for each component, together with the corresponding errors. The single component is the result of a single Gaussian fit to the emission line profiles. In order to compare our results with those of López-Sánchez \& Es- 
Figure 3. Same set of lines plotted in Figure 2 now overlapped in the same diagram. To enhance details at low luminosity levels, the y axes are shown in logarithmic scale. The evident similarity among different lines belonging to different elements confirms the presence of a complex kinematical structure. The results of fitting of individual components for the [S II] $\lambda 6717$ forbidden line is included as a reference.

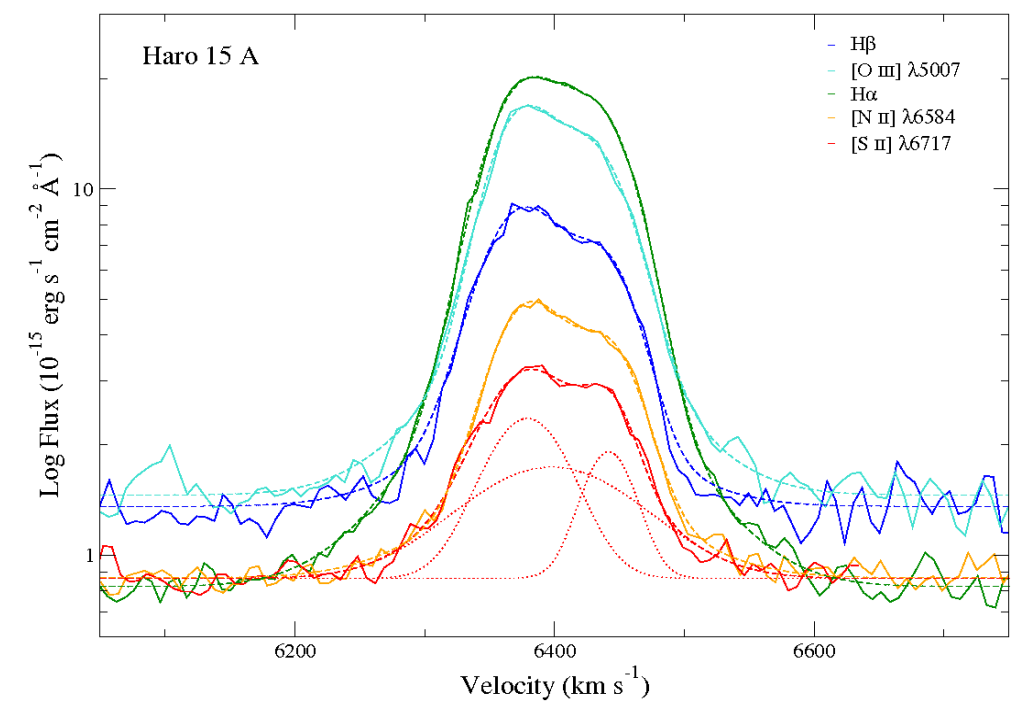

Figure 4. Top panel: Intensity distribution along the slit at the peak of the H $\alpha$ emission. Bottom panels: Result of profile extraction at the locations of regions A I and A II, together with the result of individual Gaussian profile fitting. To enhance details at low luminosity levels, the y axes are shown in logarithmic scale. Two narrow components and a broad one are fitted for A I and only a single narrow and broad component are identified in A II.

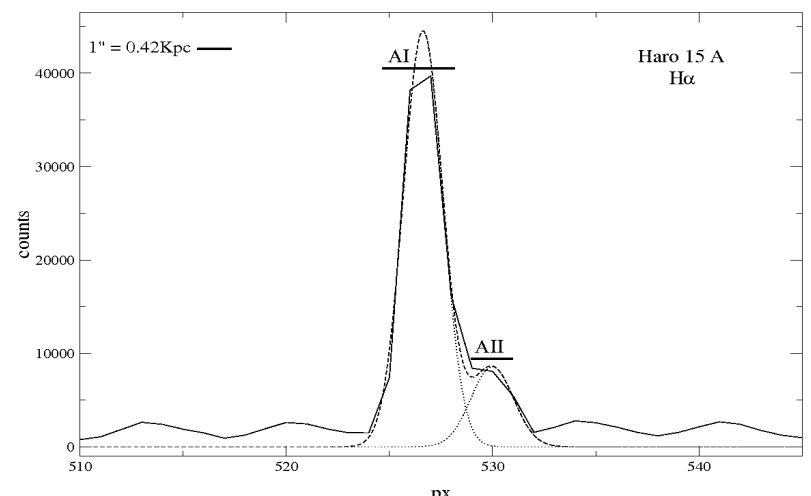

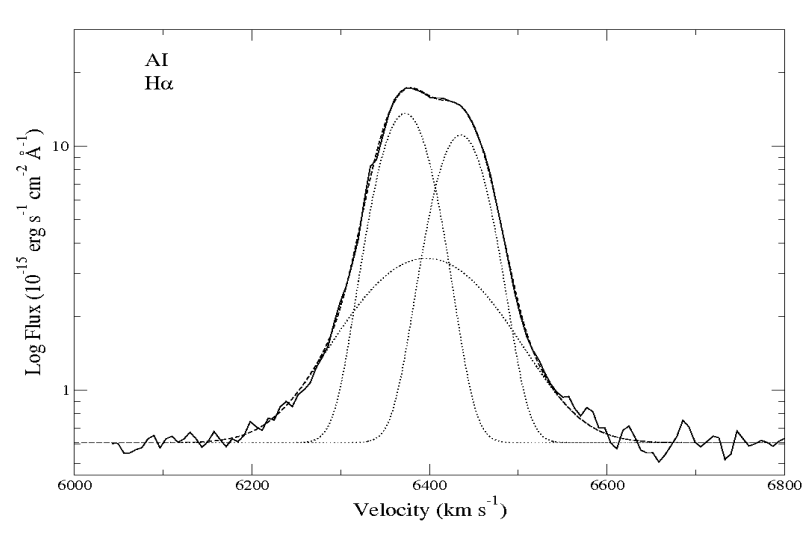

teban (2009) we have plotted our radial velocities in Figure 7 relative to the velocity of the galactic center $6415 \mathrm{~km} \mathrm{~s}^{-1}$ (López-Sánchez 2006), after correcting to the Galactic Standard of Rest (GSR) using the RVCORRECT task by IRAF. Figure 7 shows our results together with data presented by

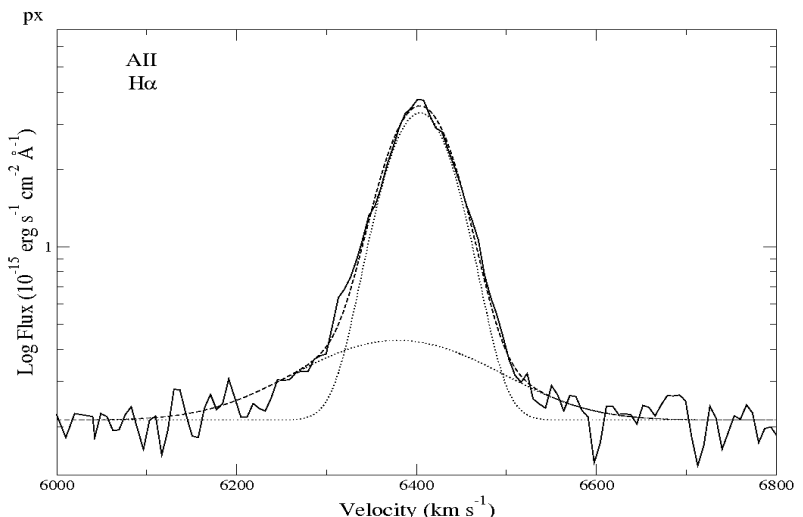

López-Sánchez \& Esteban (2009) for their long-slits with position angles (PA) of $41^{\circ}$ and $117^{\circ}$. Regarding the single component velocity, it can be clearly seen that the average radial velocities derived from the emission lines follow nicely those derived by López-Sánchez \& Esteban (2009). 
Figure 5. Ngaussfit fits with two Gaussian components in the Haro 15 B strongest emission line profiles, a narrow component and a broad one. In order: $\mathrm{H} \beta,[\mathrm{O}$ III] $\lambda 5007, \mathrm{H} \alpha,[\mathrm{N} \mathrm{II}] \lambda 6584$ and $[\mathrm{S} \mathrm{II}] \lambda 6717$. Note that the logarithmic y-scale magnifies the actual low $(1 \%)$ error in the overall fits
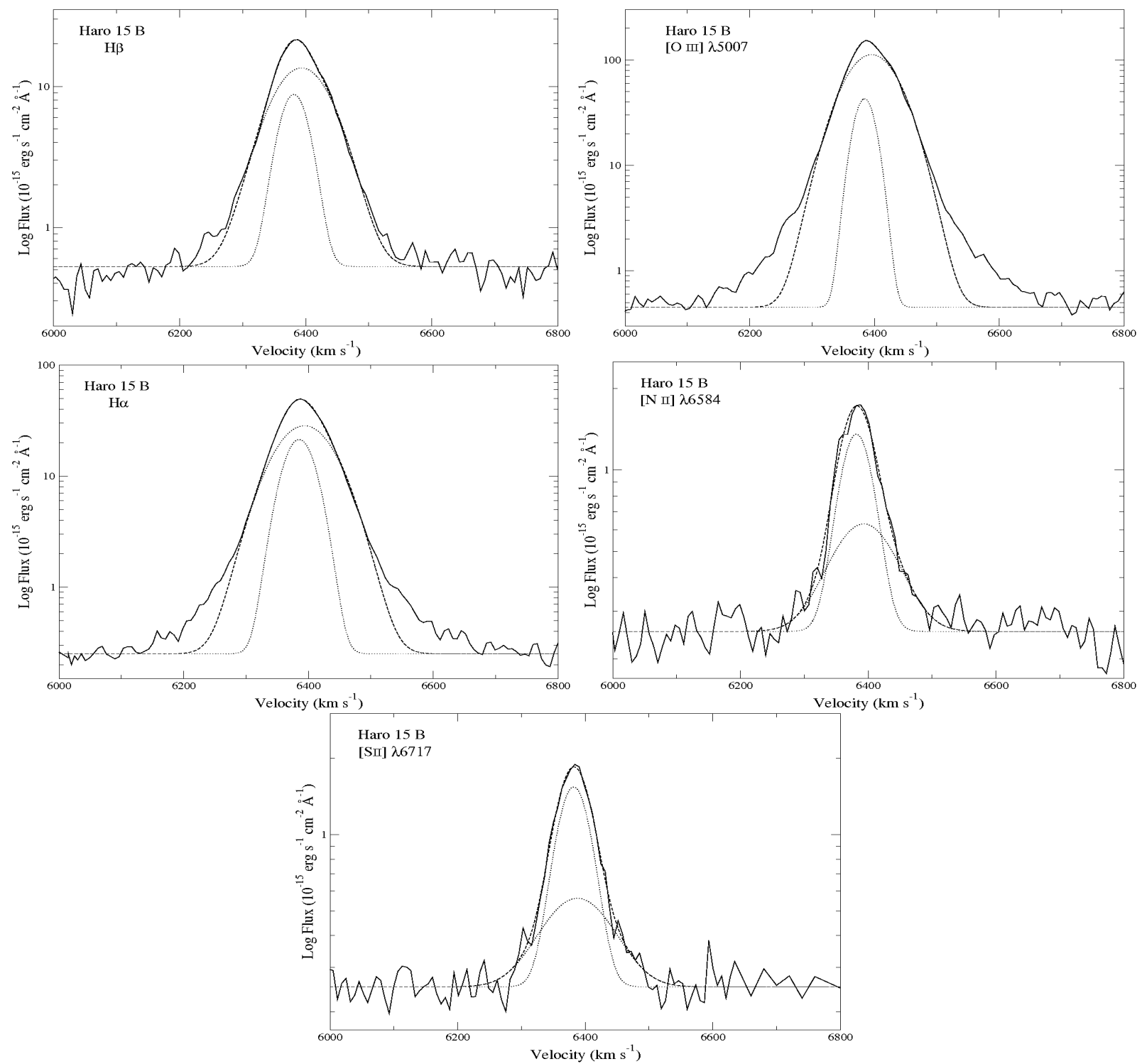

However, it is worth mentioning that individual velocities of narrow components (n1 and n2) for knot A differ by about $60 \mathrm{~km} \mathrm{~s}^{-1}$. This cannot be easily explained by scatter within galactic rotation, suggesting that their relative velocities are due to mutual orbital motion around their gravity center.

\subsection{Relation between $\mathrm{H} \alpha$ Luminosities and Velocity Dispersion}

Figure 8 shows the distribution of Haro 15 knots in the $\mathrm{L}(\mathrm{H} \alpha)$ vs. $\sigma$ plane. Each knot is labelled from $\mathrm{A}$ to $\mathrm{F}$ as used throughout this paper. Narrow components are identified with subscript $\boldsymbol{n}$ while subscript $s$ refers to line widths measured by fitting a single Gaussian component to the line. Also plotted are data on NGC 6070 and NGC 7479 from Firpo et al. (2010) and Giant Hiı Regions from Bosch et al. (2002) together with the regression line fitted by those au- thors to their "young" Giant Hiı Regions. $\mathrm{H} \alpha$ luminosities were derived from the fluxes measured directly from the component fitting to our echelle spectra, and using distances as published by de Vaucouleurs et al. (1991) for Haro 15. The correction for reddening could change flux values by a factor up to 1.72 (0.24 in logarithm) (López-Sánchez \& Esteban 2009) but, as we cannot determine it for every regions, we prefer to list the uncorrected ones.

Similar to what was found by Firpo et al. (2010), the location of the studied regions is far from random. Haro 15 HII regions show a correlation between their luminosities an velocity dispersions. If we focus on the fit of single components they seem to follow the regression found for virialised systems. The outstanding exception to this trend is region A, but this can be attributed to the fact that the profile can be split in two narrow components, resembling the behaviour found for regions NGC 7479-I and NGC 7479-II (Firpo et al. 
Table 2. Results of Gaussian profiles fitting to the observed emission lines in Haro $\mathbf{1 5} \mathbf{A}$ and $\mathbf{B}$. Each emission line is identified by its ion laboratory wavelength and ion name in columns 1 and 2. According to the different fits performed on each line, column 3 identifies each "narrow component ( 1 and 2 , where applicable), and a broad component. Radial velocities $\left(\mathrm{V}_{r}\right)$ and intrinsic velocity dispersions $\left(\sigma_{\text {int }}\right)$ together with their respective errors are expressed in $\mathrm{km} \mathrm{s}^{-1}$. The intrinsic velocity dispersions are corrected for the instrumental and thermal widths. Fractional emission measures $\left(\mathrm{EM}_{f}\right)$ in $\%$.

\begin{tabular}{|c|c|c|c|c|c|c|c|c|c|c|c|c|}
\hline \multirow[b]{2}{*}{$\lambda_{0}$} & \multirow[b]{2}{*}{ ion } & \multirow[b]{2}{*}{ comp. } & \multicolumn{5}{|c|}{ Haro $15 A$} & \multicolumn{5}{|c|}{ Haro $15 B$} \\
\hline & & & $\mathrm{V}_{r}$ & error & $\sigma_{i n t}$ & error & $\mathrm{EM}_{f}$ & $\mathrm{~V}_{r}$ & error & $\sigma_{i n t}$ & error & $\mathrm{EM}_{f}$ \\
\hline \multirow[t]{3}{*}{4861} & $\mathrm{H} \beta$ & narrow 1 & 6375.5 & 0.8 & 28.8 & 1.1 & 55.7 & 6381.2 & 0.8 & 17.3 & 1.1 & 23.6 \\
\hline & & narrow 2 & 6440.1 & 0.9 & 20.7 & 1.1 & 25.6 & $\ldots$ & $\ldots$ & $\ldots$ & $\ldots$ & $\ldots$ \\
\hline & & broad & 6390.6 & 5.2 & 72.5 & 2.4 & 18.7 & 6393.4 & 0.8 & 43.3 & 1.1 & 76.4 \\
\hline \multirow[t]{3}{*}{4959} & {$\left[\begin{array}{ll}\mathrm{O} & \mathrm{III}\end{array}\right]$} & narrow 1 & 6373.4 & 1.1 & 26.5 & 1.3 & 39.0 & 6383.2 & 0.8 & 16.5 & 1.1 & 15.5 \\
\hline & & narrow 2 & 6426.2 & 1.3 & 31.9 & 1.5 & 38.0 & $\ldots$ & $\ldots$ & $\ldots$ & $\ldots$ & $\ldots$ \\
\hline & & broad & 6384.4 & 4.7 & 64.0 & 6.0 & 23.0 & 6394.4 & 0.7 & 40.1 & 1.1 & 84.5 \\
\hline \multirow[t]{3}{*}{5007} & {$[\mathrm{O}$ III] } & narrow 1 & 6372.7 & 0.7 & 24.9 & 1.1 & 39.2 & 6384.1 & 0.8 & 15.1 & 1.1 & 13.0 \\
\hline & & narrow 2 & 6429.1 & 0.8 & 28.8 & 1.1 & 35.4 & $\ldots$ & $\ldots$ & $\ldots$ & $\ldots$ & $\ldots$ \\
\hline & & broad & 6396.2 & 1.6 & 73.0 & 2.4 & 25.4 & 6395.2 & 0.7 & 40.2 & 1.0 & 87.0 \\
\hline \multirow[t]{3}{*}{6548} & {$[\mathrm{~N}$ II $]$} & narrow 1 & 6378.7 & 1.2 & 28.6 & 1.1 & 53.4 & 6381.9 & 1.3 & 20.6 & 1.2 & 50.2 \\
\hline & & narrow 2 & 6438.3 & 1.1 & 21.5 & 1.3 & 27.9 & $\ldots$ & $\ldots$ & $\ldots$ & $\ldots$ & $\ldots$ \\
\hline & & broad & 6405.5 & 12.1 & 72.0 & 14.1 & 18.7 & 6395.6 & 4.2 & 49.0 & 4.7 & 49.8 \\
\hline \multirow[t]{3}{*}{6563} & $\mathrm{H} \alpha$ & narrow 1 & 6376.1 & 0.6 & 27.3 & 0.8 & 47.6 & 6385.0 & 0.6 & 20.0 & 0.8 & 28.4 \\
\hline & & narrow 2 & 6436.0 & 0.6 & 24.5 & 0.8 & 33.0 & $\ldots$ & $\ldots$ & $\ldots$ & $\ldots$ & $\ldots$ \\
\hline & & broad & 6395.8 & 2.6 & 77.8 & 1.7 & 19.4 & 6393.5 & 0.6 & 43.7 & 0.8 & 71.6 \\
\hline \multirow[t]{3}{*}{6584} & {$[\mathrm{~N}$ II] } & narrow 1 & 6379.9 & 0.6 & 27.5 & 0.8 & 46.6 & 6381.5 & 0.7 & 24.3 & 0.9 & 59.8 \\
\hline & & narrow 2 & 6441.9 & 0.7 & 24.5 & 0.9 & 28.1 & $\ldots$ & $\ldots$ & $\ldots$ & $\ldots$ & $\ldots$ \\
\hline & & broad & 6399.2 & 2.1 & 74.7 & 2.5 & 25.3 & 6392.9 & 2.3 & 48.4 & 2.3 & 40.2 \\
\hline \multirow[t]{3}{*}{6717} & [S II] & narrow 1 & 6379.1 & 1.2 & 31.7 & 0.9 & 38.1 & 6382.0 & 0.8 & 25.1 & 0.8 & 67.1 \\
\hline & & narrow 2 & 6441.8 & 1.2 & 19.1 & 1.3 & 16.5 & & $\ldots$ & $\ldots$ & $\ldots$ & $\ldots$ \\
\hline & & broad & 6397.9 & 2.2 & 65.5 & 2.4 & 45.5 & 6387.8 & 3.2 & 52.4 & 3.3 & 32.9 \\
\hline \multirow[t]{3}{*}{6731} & {$[\mathrm{~S}$ II $]$} & narrow 1 & 6378.3 & 1.5 & 32.3 & 1.7 & 37.2 & 6384.9 & 0.8 & 23.4 & 1.0 & 66.6 \\
\hline & & narrow 2 & 6442.3 & 1.1 & 16.7 & 1.3 & 20.2 & & $\ldots$ & $\ldots$ & $\ldots$ & $\ldots$ \\
\hline & & broad & 6398.3 & 3.4 & 65.3 & 4.3 & 42.6 & 6380.6 & 4.8 & 59.0 & 5.3 & 33.4 \\
\hline
\end{tabular}

2010). The narrow components of the composite fits show, as expected, relatively smaller luminosities and velocity widths, but they still lie around the same linear regression. In this case, it is region $\mathrm{F}$ that fails to follow the trend but, as mentioned earlier, its low velocity dispersion makes it a very unlikely candidate for a Giant His Region. It can be seen from the figure that while narrow components tend to cluster around the $\mathrm{L}(\mathrm{H} \alpha) \propto \sigma^{4}$ relation, single component fits would provide a flatter power-law exponent. This is probably due to the broad component contributing a substantial part of the total $\mathrm{H} \alpha$ flux. Although not included in the figure, the broad components are located, as expected, in a parallel sequence shifted towards lower luminosities and/or higher velocity dispersions.

\section{SUMMARY}

From high resolution spectroscopy of Haro 15 we have performed a thorough analysis of the emission line profiles of several knots considering multiple component fits to their profiles. Our results can be summarised as:

- Giant Hir Regions of Haro 15 show a complex structure within the profile of all their emission lines, detected both in recombination and forbidden lines.

- The brightest emission lines can be split in at least two strong narrow components plus an underlying broad component.

- Although regions tend to follow the galaxy kinematics, the narrow components of knot A have relative velocities that are too large to be explained by galactic rotation. This behaviour can be explained if we are observing the orbital motion around their gravity center.

- Almost all knots follow the relation found between luminosities and velocity dispersions for virialised systems, either when considering single profile fitting or the strong narrow components in more complex fits. Among these, the single one shows a relatively flatter slope.

The presence of more that one component in the Gaussian fits to the emission line profiles, such as those analysed in this paper, has been discussed in several previous studies. Hägele et al., $(2007 ; 2009 ; 2010)$ showed fits that involved the existence of broad and narrow components for the emission lines of the ionised gas in circumnuclear starforming regions. Furthermore, Firpo et al., (2010) were able to detect two distinct components within the narrow fea- 
Table 3. Results of Gaussian profiles fitting to the observed emission lines in Haro $\mathbf{1 5}$ C, E, and F. Each emission line is identified by its ion laboratory wavelength and ion name in columns 1 and 2. According to the different fits performed on each line, column 3 identifies the narrow and broad components. Radial velocities $\left(\mathrm{V}_{r}\right)$ and intrinsic velocity dispersions $\left(\sigma_{i n t}\right)$ together with their respective errors are expressed in $\mathrm{km} \mathrm{s}^{-1}$. The intrinsic velocity dispersions are corrected for the instrumental and thermal widths. Fractional emission measures $\left(\mathrm{EM}_{f}\right)$ in $\%$.

\begin{tabular}{|c|c|c|c|c|c|c|c|}
\hline$\overline{\lambda_{0}}$ & ion & comp. & $\mathrm{V}_{r}$ & error & $\sigma_{\text {int }}$ & error & $\mathrm{EM}_{f}$ \\
\hline & & & Haro 15 & $C$ & & & \\
\hline \multirow[t]{3}{*}{6563} & $\mathrm{H} \alpha$ & narrow & 6494.2 & 0.4 & 11.8 & 0.9 & 44.5 \\
\hline & & broad & 6492.7 & 0.7 & 28.5 & 1.0 & 55.5 \\
\hline & & & Haro 15 & $E$ & & & \\
\hline \multirow[t]{2}{*}{4861} & $\mathrm{H} \beta$ & narrow 1 & 6303.0 & 0.8 & 21.4 & 1.2 & 48.6 \\
\hline & & narrow 2 & 6314.4 & 1.1 & 28.2 & 1.4 & 51.4 \\
\hline \multirow[t]{2}{*}{5007} & [O III] & narrow 1 & 6302.9 & 1.7 & 23.9 & 2.2 & 32.8 \\
\hline & & narrow 2 & 6307.6 & 1.2 & 27.6 & 1.5 & 67.2 \\
\hline \multirow[t]{2}{*}{6563} & $\mathrm{H} \alpha$ & narrow 1 & 6303.0 & 0.7 & 21.4 & 0.9 & 59.1 \\
\hline & & narrow 2 & 6314.4 & 1.0 & 28.2 & 1.2 & 40.9 \\
\hline \multirow[t]{2}{*}{6584} & {$[\mathrm{~N}$ II $]$} & narrow 1 & 6306.3 & 2.0 & 22.4 & 2.9 & 31.2 \\
\hline & & narrow 2 & 6312.4 & 2.0 & 34.2 & 2.0 & 68.8 \\
\hline \multirow[t]{2}{*}{6717} & {$[\mathrm{~S}$ II $]$} & narrow 1 & 6309.0 & 1.9 & 17.6 & 1.6 & 24.9 \\
\hline & & narrow 2 & 6314.3 & 1.4 & 27.8 & 1.5 & 75.1 \\
\hline \multirow[t]{3}{*}{6731} & {$[\mathrm{~S}$ II $]$} & narrow 1 & 6306.1 & 3.5 & 14.9 & 2.3 & 29.6 \\
\hline & & narrow 2 & 6314.7 & 3.4 & 30.0 & 2.9 & 70.4 \\
\hline & & & Haro 15 & $F$ & & & \\
\hline \multirow[t]{2}{*}{6563} & $\mathrm{H} \alpha$ & narrow & 6497.7 & 1.1 & 8.3 & 1.0 & 75.9 \\
\hline & & broad & 6479.1 & 3.4 & 22.0 & 5.7 & 24.1 \\
\hline
\end{tabular}

Table 4. Average LSR radial velocities for Haro 15 emission line knots. Column 1 indicates the fitted feature and the remaining columns list the average radial velocity for each knot and its uncertainty, both in $\mathrm{km} \mathrm{s}^{-1}$.

\begin{tabular}{|c|c|c|c|c|c|c|c|c|c|c|}
\hline Comp. & $<V r>$ & error & $<V r>$ & error & $<V r>$ & error & $<V r>$ & error & $<V r>$ & error \\
\hline & \multicolumn{2}{|c|}{ Haro $15 \mathrm{~A}$} & \multicolumn{2}{|c|}{ Haro $15 B$} & \multicolumn{2}{|c|}{ Haro $15 \mathrm{C}$} & \multicolumn{2}{|c|}{ Haro $15 E$} & \multicolumn{2}{|c|}{ Haro $15 \mathrm{~F}$} \\
\hline single & 6420.3 & 0.7 & 6410.2 & 0.6 & 6514.4 & 0.6 & 6327.5 & 0.6 & 6516.3 & 0.7 \\
\hline narrow 1 & 6397.3 & 0.9 & 6403.5 & 0.8 & 6516.5 & 1.3 & 6325.4 & 1.4 & 6518.3 & 1.2 \\
\hline narrow 2 & 6457.1 & 0.9 & . & $\ldots$ & $\ldots$ & $\ldots$ & 6333.2 & 1.3 & . & . \\
\hline broad & 6418.4 & 4.4 & 6414.1 & 1.8 & 6511.5 & 4.8 & $\ldots$ & $\ldots$ & 6499.8 & 3.5 \\
\hline
\end{tabular}

Table 5. Intrinsic velocity dispersions $\left(\sigma_{\text {int }}\right)$ and the $\mathrm{H} \alpha$ luminosity $\left(\mathrm{L}(\mathrm{H} \alpha)_{s}\right)$ for a fitted single Gaussian component, together with the their associated errors, expressed in $\mathrm{km} \mathrm{s}^{-1}$ and $\mathrm{erg} \mathrm{s}^{-1}$, respectively. We add the $\mathrm{H} \alpha$ luminosity $\left(\mathrm{L}(\mathrm{H} \alpha)_{\text {overall }}\right)$ obtained from the overall $\mathrm{H} \alpha$ flux, uncorrected for reddening, and its error, in $\operatorname{ergs~s}^{-1}$.

\begin{tabular}{cccc}
\hline knot & $\sigma_{\text {int }}$ & $\mathrm{L}(\mathrm{H} \alpha)_{s}$ & $\mathrm{~L}(\mathrm{H} \alpha)_{\text {overall }}$ \\
\hline Haro 15 A & $47.3 \pm 0.9$ & $4.9 \pm 0.7 \times 10^{40}$ & $4.9 \pm 0.7 \times 10^{40}$ \\
Haro 15 B & $34.4 \pm 0.8$ & $8.6 \pm 1.2 \times 10^{40}$ & $8.9 \pm 1.3 \times 10^{40}$ \\
Haro 15 C & $19.3 \pm 0.8$ & $2.3 \pm 0.3 \times 10^{39}$ & $2.4 \pm 0.3 \times 10^{39}$ \\
Haro 15 E & $24.4 \pm 0.9$ & $4.5 \pm 0.6 \times 10^{39}$ & $4.5 \pm 0.6 \times 10^{39}$ \\
Haro 15 F & $11.6 \pm 0.8$ & $9.1 \pm 1.3 \times 10^{38}$ & $9.5 \pm 1.3 \times 10^{38}$ \\
& & & \\
\hline
\end{tabular}


Figure 6. Ngaussfit fits with three Gaussian components in the Haro $15 \mathbf{C}, \mathbf{E}$, and $\mathbf{F}$ in $\mathrm{H} \alpha$ emission line profiles, a narrow component and a broad one.

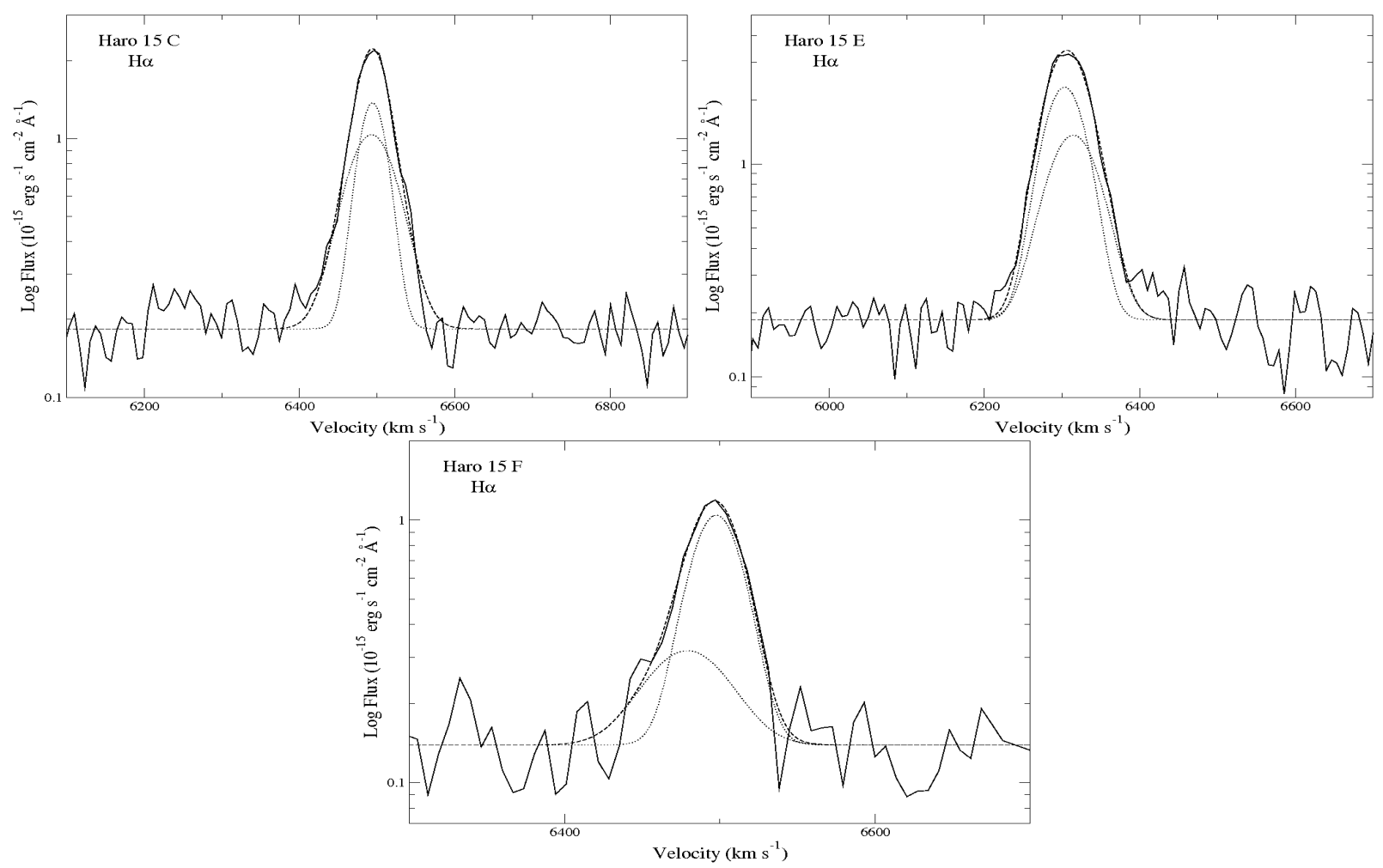

Figure 7. Position vs. Velocity diagrams for the observed knots in Haro 15 . H $\alpha$ radial velocity results, relative to knot A, are over imposed on the data by López-Sánchez \& Esteban (2009) for a slit positions PA $41^{\circ}$ (left panel) and PA $117^{\circ}$ (right panel). The H $\alpha$ and [O III] 5007 data of López-Sánchez \& Esteban (2009) in Haro 15 are identified by blue circles and red triangles, respectively.

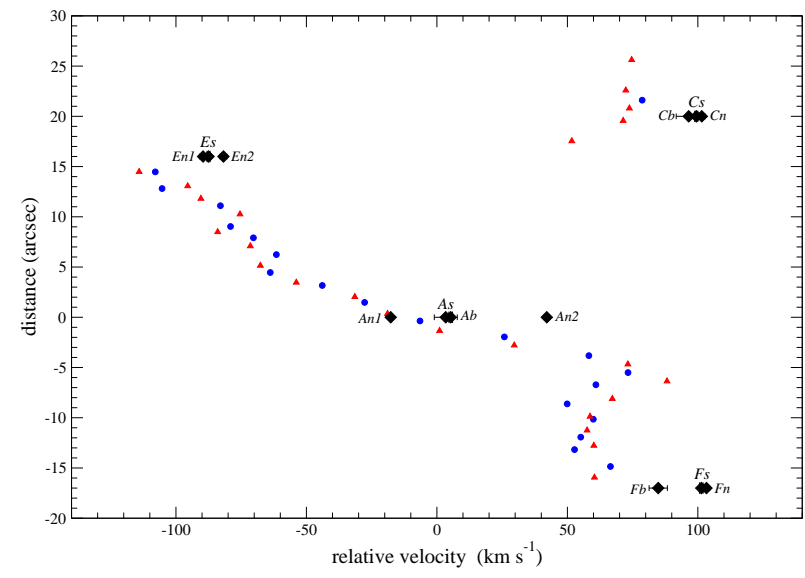

ture of the emission lines in the brightest Giant His Regions NGC 7479-I and II. Although we still lack the number of objets needed to support a generalization of this trend, these data show that the presence of multiple kinematical components among extragalactic star-forming regions cannot be overlooked. They might have a strong impact on subsequent analysis that rely on basic parameters, such as the velocity dispersion and chemical abundance of the ionised gas, the inferences about the nature and strength of the source of ionization, or the classification of the activity in the central regions of galaxies.

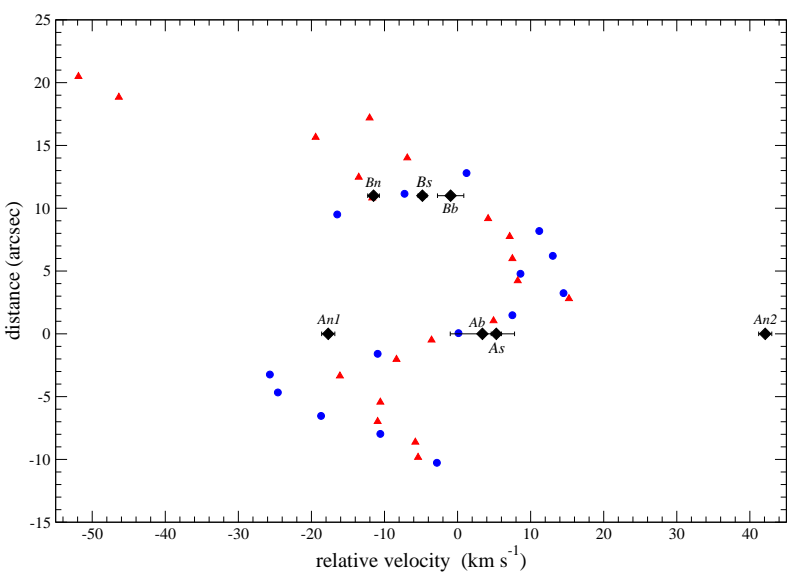

It is necessary to map these regions with high spectral and spatial resolution and much better $\mathrm{S} / \mathrm{N}$ ratio to disentangle the origin of these different components. 2D spectroscopy performed with Integral Field Unit (IFU) is the ideal tool to tackle this issue.

\section{ACKNOWLEDGEMENTS}

We are grateful to the director and staff of LCO for technical assistance and warm hospitality. We appreciate the 
Figure 8. $\log (L)-\log (\sigma)$ relation for our HII regions. Luminosities and velocity dispersions are derived from our spectrophotometric data. The plot includes results from narrow components (labelled as $\boldsymbol{n}$ ) and single profile fits (labelled as $\boldsymbol{s}$ ). We add the data from Firpo et al. (2010) (n, nA and nB for narrow, and $\mathrm{g}$ for single components) identified by color solid error bars and with numbers (from 1 to 6): NGC 7479-I (1) in red, NGC 7479-II (2) in green, NGC 7479-III (3) in yellow, NGC 6070-I (4) in maroon, NGC 6070-II (5) in violet and NGC 6070-IV (6) in magenta. A few Giant Hir Regions from Bosch et al. (2002) (blue dashed error bars) together with their linear fit to their "young" Giant Hir Regions are plotted as a reference value. The luminosities are not corrected for extinction.

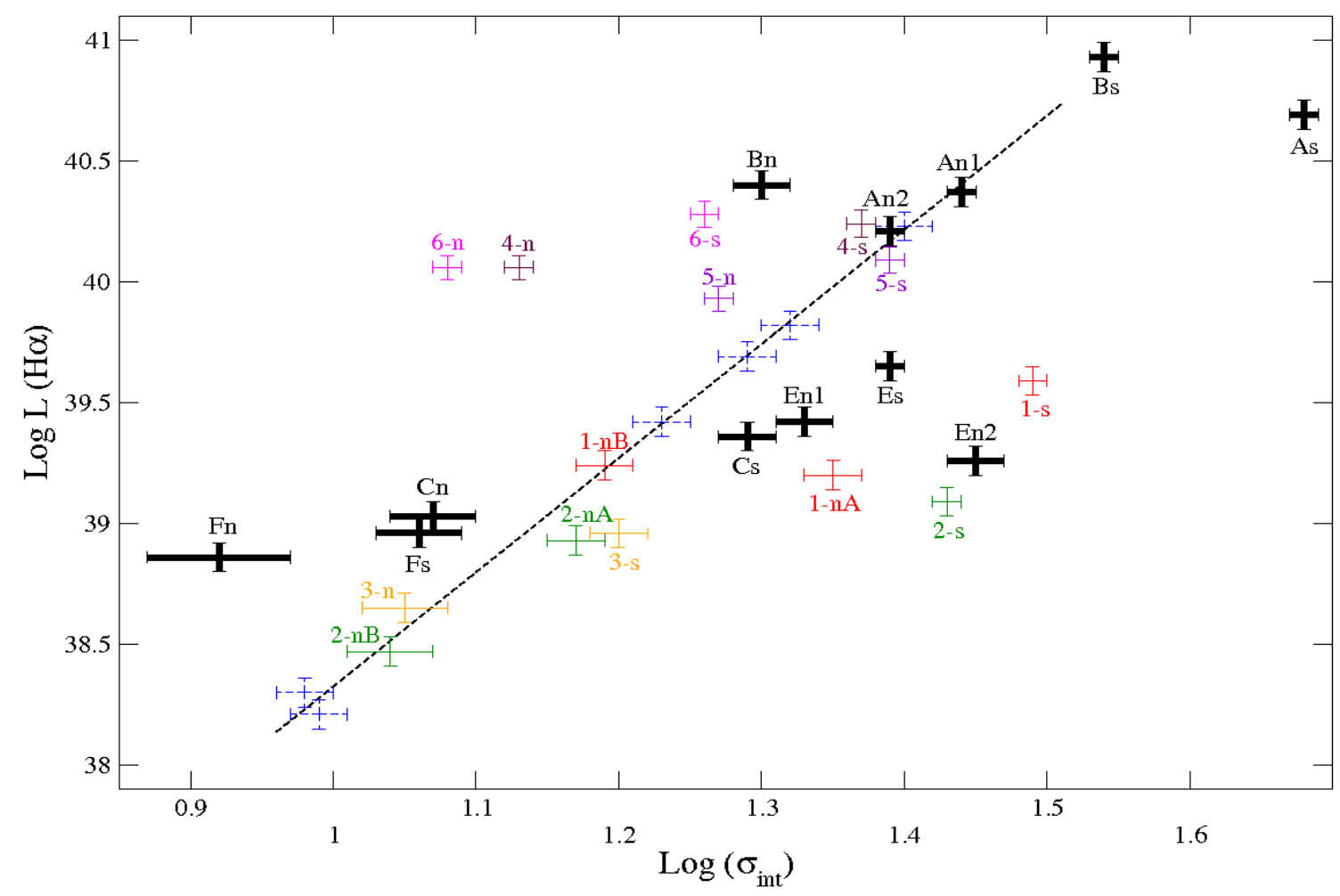

comments and suggestions by the referee, Ángel R. LópezSánchez, which significantly improved this paper. This research has made use of the NASA/IPAC Extragalactic Database (NED) which is operated by the Jet Propulsion Laboratory, California Institute of Technology, under contract with the National Aeronautics and Space Administration. Support from the Spanish Ministerio de Educación y Ciencia (AYA2007-67965-C03-03, AYA2010-21887-C04-03), and partial support from the Comunidad de Madrid under grant S2009/ESP-1496 (ASTROMADRID) is acknowledged. VF and GB would like to thank the hospitality of the Astrophysics Group of the UAM during the completion of this work. 


\section{REFERENCES}

Bohlin R. C., Dickinson M. E., Calzetti D., 2001, ApJ, 122, 2118

Bosch G., Terlevich E., Terlevich R., 2002, MNRAS, 329, 481

Cairós L. M., Caon N., Vílchez J. M., González-Pérez J. N., Muñoz-Tuñón C., 2001, ApJS, 136, 393

Cairós L. M., Vílchez J. M., González Pérez J. N., Iglesias-

Páramo J., Caon N., 2001, ApJS, 133, 321

Chu Y. H., Kennicutt R. C. J., 1994, ApJ, 425, 720

Cumming R. J., Fathi K., Östlin G., Marquart T., Márquez I., Masegosa J., Bergvall N., Amram P., 2008, A\&A, 479, 725

de Vaucouleurs G., de Vaucouleurs A., Corwin H. G., Buta R. J., Paturel G., Fouque P., 1991, Third Reference Catalogue of Bright Galaxies, version 3.9. vol. p.

Firpo V., Bosch G., Hägele G. F., Morrell N., 2010, MNRAS, 406, 1094

Firpo V., Bosch G., Morrell N., 2005, MNRAS, 356, 1357

García-Rojas J., Esteban C., Peimbert A., Peimbert M., Rodríguez M., Ruiz M. T., 2005, MNRAS, 362, 301

Hägele G. F., Díaz Á. I., Cardaci M. V., Terlevich E., Terlevich R., 2007, MNRAS, 378, 163

Hägele G. F., Díaz Á. I., Cardaci M. V., Terlevich E., Terlevich R., 2009, MNRAS, 396, 2295

Hägele G. F., Díaz Á. I., Cardaci M. V., Terlevich E., Terlevich R., 2010, MNRAS, 402, 1005

Hammer F., Gruel N., Thuan T. X., Flores H., Infante L., 2001, ApJ, 550, 570

Hippelein H. H., 1986, Astron. Astrophys, 160, 374

Hoyos C., Guzmán R., Bershady M. A., Koo D. C., Díaz A. I., 2004, AJ, 128, 1541

Hoyos C., Guzmán R., Díaz A. I., Koo D. C., Bershady M. A., 2007, AJ, 134, 2455

Hunter D. A., Gallagher I. J. S., 1985, AJ, 90, 1457

Kong X., Cheng F. Z., Weiss A., Charlot S., 2002, A\&A, 396,503

Kovo O., Contini T., 1999, in K. A. van der Hucht, G. Koenigsberger, \& P. R. J. Eenens ed., Wolf-Rayet Phenomena in Massive Stars and Starburst Galaxies Vol. 193 of IAU Symposium, Systematic search for Wolf-Rayet stars in young starbursts. p. 604

López-Sánchez Á. R., 2006, PhD thesis, Instituto de Astrofísica de Canarias

López-Sánchez Á. R., 2010, A\&A, 521, 63

López-Sánchez Á. R., Esteban C., 2008, A\&A, 491, 131

López-Sánchez Á. R., Esteban C., 2009, A\&A, 508, 615

López-Sánchez Á. R., Esteban C., 2010, A\&A, 516, 104

López-Sánchez Á. R., Esteban C., García-Rojas J., 2006, A\&A, 449, 997

López-Sánchez Á. R., Esteban C., Rodríguez M., 2004, A\&A, 428, 425

Mazzarella J. M., Bothun G. D., Boroson T. A., 1991, AJ, 101, 2034

Melnick J., Tenorio-Tagle G., Terlevich R., 1999, MNRAS, 302,677

Muñoz-Tuñón C., Tenorio-Tagle G., Castañeda H. O., Terlevich R., 1996, AJ, 112, 1636

Osterbrock D. E., Fulbright J. P., Martel A. R., Keane M. J., Trager S. C., Basri G., 1996, Publications of the Astronomical Society of the Pacific, 108, 277
Östlin G., 1998, PhD thesis, Uppsala University

Relaño M., Beckman J. E., 2005, A\&A, 430, 911

Roy J. R., Arsenault R., Joncas G., 1986, AJ, 300, 624

Rozas M., Richer M. G., López J. A., Relaño M., Beckman

J. E., 2006, aap, 455, 539

Schaerer D., Contini T., Pindao M., 1999, A\&AS, 136, 35

Shi F., Kong X., Li C., Cheng F. Z., 2005, A\&A, 437, 849

Terlevich R., Melnick J., 1981, MNRAS, 195, 839 
Capítulo 4

\section{Determinación de abundancias del gas ionizado para las diferentes componentes cinemáticas}

El análisis de la distribución de densidad y temperaturas electrónicas en el interior de una nebulosa de gas ionizado permite analizar las propiedades físicas del medio interestelar y determinar las abundancias químicas iónicas y totales de dicho gas. La determinación de la abundancia de cada ión está asociada a su temperatura electrónica. En aquellos casos en que estas temperaturas no son medibles directamente a través de las líneas de emisión aurorales sensibles a la temperatura se suelen utilizar relaciones con otras temperaturas iónicas determinadas empíricamente o derivadas utilizando modelos de fotoionización. El análisis de los parámetros físicos tales como densidad, temperatura, composición química, etc., puede llevarse adelante mediante el estudio de las intensidades relativas de las líneas de emisión del gas. En este Capítulo se procede a determinar las propiedades físicas del gas en los distintos brotes de formación estelar de Haro 15 en cada componente cinemática ajustada en los perfiles de las líneas de emisión. Si bien este tipo de análisis desglosado para las diferentes componentes cinemáticas no es la primera vez que se realiza, este trabajo presenta una mayor completitud frente a otros trabajos publicados dada la calidad de nuestros datos y la gran cantidad de líneas analizadas, entre las que se encuentran las débiles líneas aurorales, sumado a la posibilidad de descomponer sus perfiles en más de una componente angosta y una componente ancha. Es allí donde radica el carácter relevante de este Capítulo para esta Tesis.

\subsection{Introducción}

Este Capítulo se centra en el estudio de regiones H II de baja metalicidad como lo son las regiones ubicadas en las galaxias Enanas Compactas Azules (BCDs, sigla en inglés de Blue Compact Dwarf galaxies), que pertenecen a la clase de galaxias más numerosa del Universo: las galaxias enanas. Los espectros de las BCDs están dominados por la emisión del gas asociado a cúmulos estelares formados por estrellas jóvenes y calientes que ionizan el medio 
interestelar, y estas galaxias se caracterizan por su color azul, aspecto compacto, alto contenido de gas, fuertes líneas de emisión nebular y abundancias químicas bajas (Kunth \& Östlin, 2000; Stasińska et al., 2001). Gran parte de los objetos con espectros de emisión en el régimen de alta excitación, siendo este régimen de gran importancia para el estudio de la metalicidad y de las propiedades de la población estelar, son galaxias H II. Las galaxias H II son galaxias irregulares de baja masa con al menos un episodio de formación estelar violento concentrado en unos pocos parsecs cerca a su núcleo (Melnick et al., 1985aa, 1985bb). Presentan un alto brillo superficial, intenso color azul y baja metalicidad con espectros de emisión debidos al gas ionizado. Actualmente, se ha multiplicado el interés en estudiar las propiedades de este tipo de objetos menos metálicos, dado que existen indicios de que pudieran tratarse de objetos jóvenes y, por lo tanto, proporcionarían importantes pistas acerca de la formación estelar en estas condiciones, al margen de la trascendencia que tienen para la búsqueda de helio primordial.

El término galaxia $\mathrm{H}$ II se utiliza cuando se hace referencia a objetos seleccionados a partir de placas obtenidas mediante la técnica del prisma-objetivo cuyo criterio de búsqueda son las líneas de emisión (por ejemplo, Terlevich et al., 1991), mientras que las BCDs son objetos seleccionados en base a su color muy azul y su aspecto compacto en las placas fotográficas. De todos modos ambos términos suelen designar a los mismos objetos, ya que sus propiedades observables en el óptico están dominadas por el espectro de la región H in en la zona de formación estelar.

Los primeros trabajos sobre estos objetos compactos son los de Haro (1956) y Zwicky et al. (1965) que distinguen estas galaxias de gran brillo superficial en sus placas fotográficas. Sargent \& Searle (1970) encuentran que casi todos estos objetos presentan un espectro dominante de líneas de emisión como el de las regiones H in en los discos de las galaxias espirales y las denominan Regiones H ir Gigantes Extragalácticas aisladas. Generalmente se componen de una región central de unos pocos cientos de parsecs de diámetro con un elevado brillo superficial en la cual se están formando miles de nuevas estrellas en un proceso de formación estelar violento (starburst, de su significado en inglés) (Searle \& Sargent, 1972) y de una galaxia de cientos de parsecs de diámetro de baja luminosidad $\left(\mathrm{M}_{v} \approx-17\right)$, pudiendo alcanzar unos pocos kpc cuando se la observa en los filtros $\mathrm{V}$ y $\mathrm{R}$, excediendo el tamaño de la región de formación estelar (Cairós et al., 2001).

En general, las líneas de emisión observadas en los espectros tanto de las galaxias H II como de las BCDs son muy similares a las de Regiones H II Gigantes Extragalácticas. Por lo tanto, mediante la aplicación de las mismas técnicas de medición que en las regiones HiI, pueden ser derivadas las temperaturas, densidades y composición química del gas interestelar en los brotes de formación estelar de este tipo de galaxias deficientes en metales (Sargent \& Searle, 1970; French, 1980; Terlevich et al., 1991). Sometidas a intensos brotes de formación estelar, espectros con intensas y angostas líneas de emisión, extinción de polvo relativamente pequeña, entornos de baja metalicidad y diferentes historias de formación estelar, hacen que 
las galaxias BCDs sean los más apropiados laboratorios para estudiar la metalicidad de las galaxias (Kunth \& Östlin, 2000).

En el Capítulo anterior se presentó un estudio detallado de la cinemática interna del material nebular en múltiples regiones de formación estelar de la galaxia BCD Haro 15. De la espectroscopía de alta resolución, obtenida en el Observatorio Las Campanas, Chile, se ha realizado un análisis exhaustivo de sus líneas de emisión, incluyendo los ajustes de múltiples componentes a sus perfiles de emisión. Los resultados obtenidos han demostrado que las regiones Hil de Haro 15 presentan una estructura compleja en los perfiles de sus líneas de emisión, detectada tanto en las líneas de recombinación del hidrógeno y helio como también en las líneas prohibidas. La emisión de la región más brillante puede ser dividida en, al menos, dos componentes angostas más una componente ancha. Aunque las regiones tienden a seguir la cinemática de la galaxia, las componentes del brote A tienen velocidades relativas demasiado grandes para ser explicadas por la rotación galáctica. La mayoría de las regiones siguen la relación encontrada entre la luminosidad y la dispersión de velocidades para sistemas virializados, ya sea cuando se considera un ajuste de perfil simple o un ajuste más complejo con varias componentes, excepto cuando se considera la componente ancha del ajuste. Entre todas estas componentes, la componente simple muestra una pendiente relativamente más plana que el resto.

En general, la calibración en flujo de datos échelle es difícil de comprobar y las líneas débiles, sensibles a la temperatura, tienen una relación señal-ruido relativamente baja para permitir una medición confiable. Los datos espectroscópicos de ranura larga con resolución intermedia son más sensibles para realizar un análisis de las abundancias. Dichas abundancias dependen de la precisión de las temperaturas estimadas. La combinación del échelle y de ranura larga brinda la oportunidad de interpretar el resultado de la abundancia a la luz de la cinemática interna de las regiones.

Shi et al. (2005) encuentran un promedio de 8.56 en el logarítmo de las abundancias totales de oxígeno de Haro 15, para una temperatura electrónica de 8330 K. Sin embargo, se sabe por un trabajo anterior (Cairós et al., 2001) que la imagen $\mathrm{H} \alpha$ muestra una morfología nudosa con la región estelar resuelta en un gran número de grupos que aparecen dispersos en toda la galaxia. En López-Sánchez \& Esteban (2009b) los autores muestran espectroscopía de los diferentes nudos espacialmente resueltos y determinan densidades, temperaturas y abundancias químicas de los brotes A, B y C de Haro 15 (siguiendo la nomenclatura de Cairós et al., 2001). Las abundancia derivadas de oxígeno fueron de $12+\log (\mathrm{O} / \mathrm{H})=8.37 \pm 0.10$ y $8.10 \pm 0.06$ para las regiones A y B, respectivamente.

Esteban \& Vilchez (1992) introducen el término "chemodynamics" al conbinar por primera vez, información química y cinemática en orden de realizar un estudio químico-dinámico de la nebulosa anillo W-R, NGC 6888. Los autores combinan observaciones de alta resolución espectral con observaciones de alta resolución espacial para las diferentes zonas de la nebulosa, 
lo cual les permite analizar las diferentes componentes en velocidad de la región estudiada.

Más tarde, James et al., (2009), realizaron un estudio en la galaxia BCD Mrk 996 basado en alta resolución espectral con VLT VIMOS en modo IFU. Encontraron que la galaxia Mrk 996 presenta multicomponentes en los perfiles de sus líneas de emisión, descomponiendo los mismos en una componente angosta y una componente ancha, llevando a cabo un análisis de las propiedades físicas separado por componentes. Según los autores esta peculiar galaxia BCD presenta en el núcleo zonas extremadamente densas de gas, a través del cual los outflows estelares y posibles frentes de choque contribuyen a la excitación de la emisión ancha. Ellos detectaron que las líneas de Balmer muestran una estructura común en velocidad de multicomponentes anchas que no es observable en las líneas prohibidas. Las líneas prohibidas con excepción de [OIII] $\lambda 4363$ y [NII] $\lambda 5755$, pudieron ser ajustadas con una componente angosta y una componente ancha. En cambio el perfil de emisión de ninguna de las líneas aurorales sensibles a la temperatura, como por ejemplo las líneas de [OIII] y [NII] que acabínamos de mencionar, pudo ser descompuesto en más de una componente, sólo en estas dos líneas aurorales los perfiles de emisión pudieron ser ajustados con una componente ancha. Si bien el análisis de abundancias por componentes presentes en los perfiles de las líneas de emisión es llevado a cabo por James y colaboradores, la diferencia fundamental con nuestro trabajo radica en que nosotros pudimos descomponer algunas de las líneas aurorales sensibles a la temperatura electrónica en sus diferentes componentes cinemáticas suponiendo que dicha solución de multicomponentes cinemáticas es la misma que se encuentra en las líneas más intensas del espectro con igual grado de ionización.

En este Capítulo se realiza un análisis de las características del gas ionizado discriminado para cada componente y para el flujo global de las líneas. Para esto se estimaron temperaturas y densidades electrónicas, y se obtuvieron abundancias iónica y totales de las diferentes especies como ser: O, S, N, Ne, Ar.

En lo que sigue, se explicarán las observaciones y la reducción de los datos, y a continuación se mostrarán los resultados obtenidos. En la Sección 4.4 se explicarán los diferentes métodos utilizados para determinar las condiciones físicas del gas ionizado (densidades y temperaturas electrónicas), como las abundancias químicas derivadas y sus incertezas. En la Sección 4.5 se discuten los datos dando las respectivas conclusiones. Y finalmente, en la Sección 4.6 se presenta un resumen y las conclusiones del Capítulo.

\subsection{Observaciones y Reducción de los datos}

Se obtuvieron espectros de resolución intermedia de ranura larga usando la cámara WideField CCD (WFCCD) montada en el telescopio du Pont de 100" del Observatorio Las Campanas (LCO) en Chile (28 de septiembre de 2005). Las observaciones obtenidas corresponden a las regiones B y C de Haro 15 (ver Figura 1 del Capítulo 3). El detector TEK5 que se utilizó cubre todo el rango de longitud de onda óptica, desde 3800 a $9300 \AA$ (centrado en $\lambda_{c}=6550 \AA$ ). 
La resolución espectral alcanzada en los espectros es de $\mathrm{R}_{F W H M} \simeq 900: \Delta \lambda_{F W H M}=7.5 \AA$ a los $\lambda 6700 \AA$, medida a partir del ancho a potencia mitad (FWHM) de las líneas de la lámpara de comparación de Thorio-Argón tomadas con el fin de calibración de longitud de onda. Las observaciones se realizaron en ángulo paraláctico, para evitar los efectos de refracción diferencial en el ultravioleta, en excelentes condiciones fotométricas, con un seeing de 1 segundo de arco. Al comienzo de la noche se tomaron bias (nivel de pedestal o cuentas que tiene de base el detector aún sin exponer) y flat-field (del inglés, imagen de campo plano) de cúpula. Además, en esta misma noche se tomaron espectros de la lámpara de comparación Th-Ar. Las imágenes fueron procesadas y analizadas con las rutinas de $\mathrm{IRAF}^{1}$ mediante el procedimiento usual. El procedimiento incluye la eliminación de rayos cósmicos, resta de bias, división por un flat-field normalizado y calibración en longitud de onda. Se observó una estrella estándar, EG 131, para la calibración en flujo y el tiempo de exposición para esta estrella estándar de flujo fue de 180 segundos. Los espectros fueron corregidos por extinción atmosférica.

Se ha encontrado un cierto grado de contaminación de segundo orden en estos espectros de ranura larga. La misma comienza a estar presente en $\lambda>6000 \AA$ y es casi imposible de eliminar por completo debido a la amplia cobertura espectral usada. Por este motivo, los flujos medidos para las líneas nebulares que se encuentran más allá de los $6000 \AA$ han sido sistemáticamente subestimados, aunque nunca esta contribución es importante para los cocientes de líneas (ver Terlevich et al., 1991).

Por otro lado, se obtuvieron espectros de alta resolución usando el espectrógrafo échelle en el telescopio du Pont de 100" de LCO, entre el 19 y el 20 de julio de 2006. Las observaciones obtenidas corresponden a varios brotes de formación estelar de la misma galaxia Haro 15 (A, B, C, E y F) adquiridos en el modo échelle (ver Capítulo 3). El desplazamiento al rojo calculado con estos datos es de $\mathrm{z}=0.021306$. El rango espectral abarcado en estas observaciones es desde 3400 hasta $10000 \AA$ A. Este rango espectral garantiza la medición simultánea de las líneas nebulares de $[\mathrm{OII}] \lambda \lambda 3727,3729 \AA$ a las del [SIII] $\lambda \lambda$ 9069, $9532 \AA$ en ambos extremos del espectro y en la misma región de la galaxia. Las condiciones de observación fueron buenas con un seeing de 1 segundo de arco. La estrella espectrofotométrica estándar observada para la calibración en flujo fue Feige 110 (Bohlin et al., 2001), la cual tiene sus flujos tabulados cada $2 \AA$, y la cantidad de intervalos definidos dentro de un orden del échelle varía de cuatro a doce, dependiendo de la calidad del espectro. El tiempo de exposición de la estrella estándar fue de 1200 segundos. La calibración en flujo obtenida en estos datos fue muy buena. Para los detalles de reducción y el proceso de análisis ver Capítulo 3.

La Tabla 4.1 lista las observaciones obtenidas, junto con los tiempos de exposición y las masas de aire para cada región y su respectivo modo de observación.

\footnotetext{
${ }^{1}$ Image Reduction and Analysis Facility, distribuida por NOAO, operada por AURA, Inc., bajo acuerdo con NSF.
} 
Tabla 4.1: Observaciones de los diferentes brotes en Haro 15. La primera columna indica el modo de observación, la segunda columna muestra la nomenclatura utilizada en el Capítulo 3 siguiendo Cairós et al., (2001), la tercera columna corresponde a la fecha de observación, la cuarta columna exhibe el tiempo de exposición de los brotes, la quinta columna señala las masas de aire.

\begin{tabular}{ccccc}
\hline Modo & brote & fecha & t.exp & sec z \\
\hline ranura larga & $\mathrm{B}, \mathrm{C}$ & 2005 Sep 28 & 2x1200+1x900 & 1.5 \\
échelle & & & & \\
& $\mathrm{A}$ & 2006 Jul 19 & 1800 & 1.2 \\
& $\mathrm{~B}$ & 2006 Jul 19 & 1800 & 1.1 \\
& $\mathrm{C}$ & 2006 Jul 19 & 1800 & 1.1 \\
& $\mathrm{E}$ & 2006 Jul 20 & 1800 & 1.2 \\
& $\mathrm{~F}$ & 2006 Jul 20 & 1800 & 1.1 \\
\hline
\end{tabular}

\subsection{Resultados}

En la Figura 4.1 se han marcado algunas de las líneas de emisión más relevantes observadas en los espectros WFCCD de ranura larga de los brotes B y C de Haro 15.

Los flujos de las líneas de emisión para los datos de ranura larga se midieron utilizando la tarea splot de IRAF (que integra la intensidad de cada línea sobre un continuo ajustado localmente) siguiendo el mismo procedimiento descripto en Hägele et al. (2006). Se utilizaron dos formas de integrar el flujo de la línea de emisión: (i) en el caso de una línea aislada o dos líneas fusionadas y sin resolver, la intensidad es calculada integrando entre dos puntos dados por la posición del continuo local colocados a ojo. A este flujo, que incluye todas las diferentes componentes cinemáticas, se lo denominará, de ahora en más, como "medida global"; (ii) si dos líneas están fusionadas, pero se pueden resolver, se utiliza el procedimiento de múltiples ajustes Gaussianos para estimar los flujos individuales (esto se aplicó solamente para los datos de dispersión simple). Ambos procedimientos están explicados detalladamente en Hägele et al., (2006; 2008).

Siguiendo Pérez-Montero \& Díaz (2003), los errores estadísticos asociados a los flujos de las emisiones observadas se han calculado utilizando la expresión

$$
\sigma_{l}=\sigma_{c} N^{1 / 2}[1+E W /(N \Delta)]^{1 / 2}
$$

donde $\sigma_{l}$ es el error en el flujo de la línea observada, $\sigma_{c}$ representa la desviación estándard en una caja cerca de la línea de emisión medida y representa el error en la posición del continuo, $\mathrm{N}$ es el número de píxeles en la medida del flujo de la línea, EW es el ancho equivalente de la línea el cual está dado por el flujo del continuo cerca de la línea y el flujo de la línea, y $\Delta$ es la dispersión de la longitud de onda en angstroms por pixel (González-Delgado et al., 1994). 

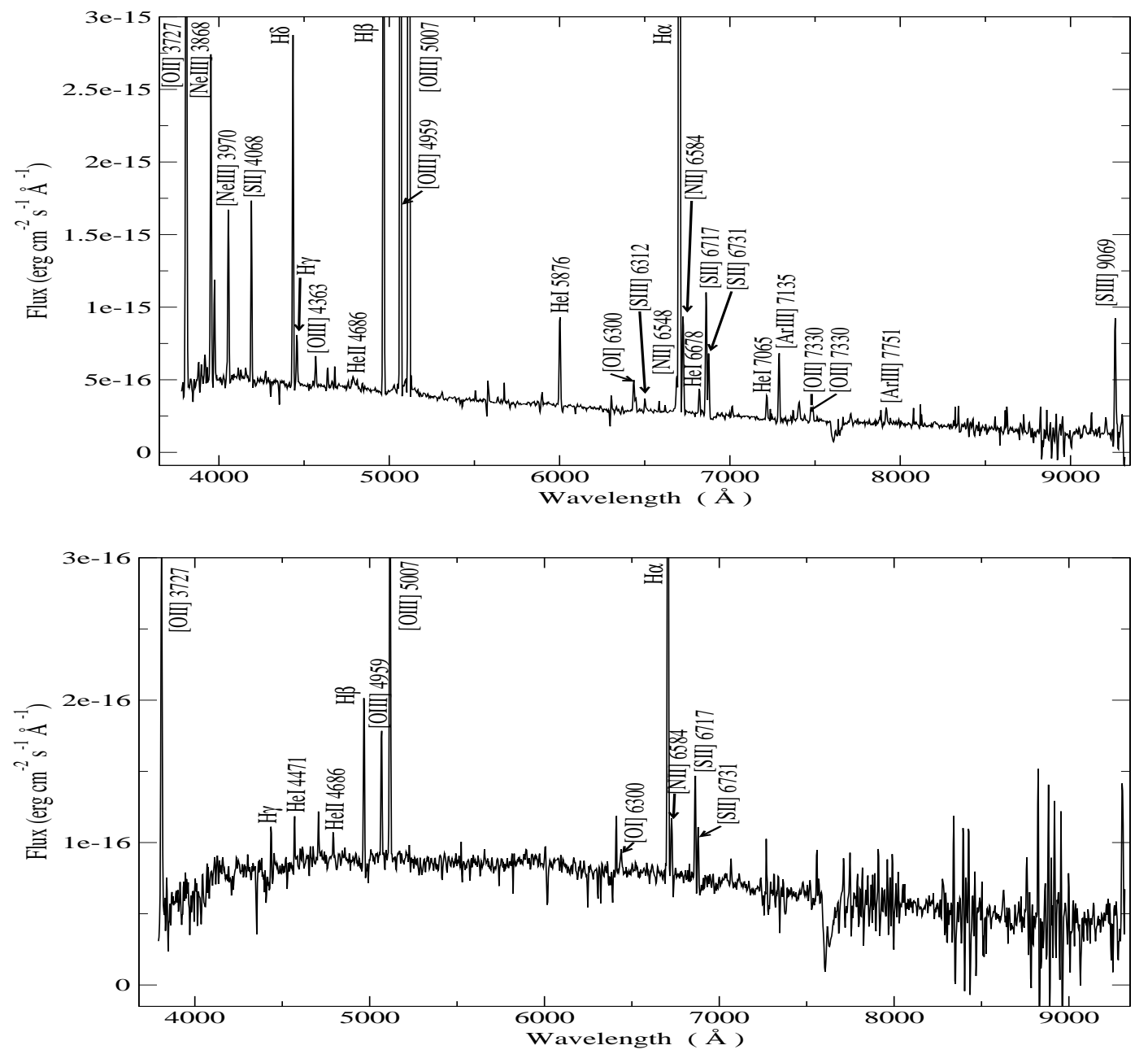

Figura 4.1: Espectros de líneas de emisión de ranura larga obtenidos para los brotes $\mathbf{B}$ y $\mathbf{C}$ (paneles superior e inferior, respectivamente) sin corrección Doppler. 
Cada intensidad medida debe ser corregida de enrojecimiento. La constante de enrojecimiento $c(H \beta)$ se puede calcular a partir del decremento de Balmer de las líneas de recombinación de hidrógeno más intensas. Una población estelar subyacente es fácilmente apreciable debido a la presencia de alas en las absorciones que deprimen las líneas de emisión de Balmer en los espectros de ranura larga y échelle. Para medir las intensidades de las líneas y minimizar los errores introducidos por la población subyacente, se define un pseudo-continuo en la base de las líneas de emisión del hidrógeno (ver discusión en Hägele et al., 2006). La presencia de alas en las líneas de absorción implica que, a pesar de que se ha utilizado un pseudo-continuo, aún existe una fracción absorbida del flujo emitido que no es posible medir con precisión (ver la discusión al respecto en Díaz, 1998). Esta fracción no es la misma para todas las líneas, ni lo son los cocientes entre las fracciones absorbidas y la emisión. Hägele et al. (2006) estimaron que la diferencia entre los valores obtenidos usando el pseudo-continuo definido o un ajuste múltiple Gaussiano de las componentes de absorción y emisión es la misma, dentro de los errores, para todas las líneas de Balmer. En cualquier caso, siguiendo este trabajo, para las líneas de emisión de Balmer se ha duplicado el error derivado, $\sigma_{l}$, como un enfoque conservador para incluir la incertidumbre introducida por la presencia de la población estelar subyacente.

La ley que permite obtener la constante de enrojecimiento a partir del decremento de Balmer de las líneas de recombinación más intensas del hidrógeno y que una vez obtenidas, permite corregir el resto de las líneas de emisión, tiene la siguiente forma:

$$
\frac{I_{0}(\lambda)}{I_{0}(H \beta)}=\frac{I(\lambda)}{I(H \beta)} \cdot 10^{-c(H \beta) \cdot[f(\lambda)-f(H \beta)]}
$$

donde $I(\lambda)$ es la intensidad de la línea que se quiere corregir e $I_{0}(\lambda)$ es el valor corregido en relación a $H \beta, c(H \beta)$ es la constante de enrojecimiento y $f(\lambda)$ es la función de extinción. Los valores teóricos de las líneas de recombinación del hidrógeno que permiten calcular $c(H \beta)$ son función de la temperatura electrónica y de la densidad, lo cual implicará que se debe realizar un procedimiento iterativo para calcularlo.

El coeficiente de enrojecimiento ha sido calculado asumiendo la ley de extinción galáctica de Miller \& Mathews (1972) con $R_{\mathrm{v}}=3.2$, que es el valor para la Galaxia, y la cual toma la forma:

$$
f(\lambda)-f(H \beta)=\left\{\begin{array}{l}
0,477 \lambda^{-1}-1,209, \lambda^{-1} \leq 2,29 \\
0,342 \lambda^{-1}-0,645, \lambda^{-1}>2,29
\end{array}\right.
$$

donde $\lambda$ es la longitud de onda de la línea a calcular en unidades de micrones.

Luego, la constante de enrojecimiento, $\mathrm{C}(\mathrm{H} \beta)$, fue obtenida mediante la realización de un ajuste de mínimos cuadrados a la relación entre $\mathrm{F}(\lambda)$ y $\mathrm{F}(\mathrm{H} \beta)$ para los valores teóricos calculados por Storey \& Hummer (1995), usando el método iterativo que aplicó Hägele (2008) para estimar $T_{e}$ y $n_{e}$ según sea el caso. Los valores iniciales tomados, cuando éstos estan disponibles, son aquellos derivados de la medida de los flujos de las líneas [SII] $\lambda \lambda 6717,6731 \AA$ 
y [OIII] $\lambda \lambda 4363,4959,5007 \AA$. Debido a los grandes errores introducidos por la presencia de la población estelar subyacente, solo se han tenido en cuenta las cuatro líneas de emisión de Balmer más intensas $(\mathrm{H} \alpha, \mathrm{H} \beta, \mathrm{H} \gamma$ y $\mathrm{H} \delta)$.

Por otro lado, los flujos asociados a cada componente cinemática identificadas en los datos de alta resolución espectral (échelle) para las líneas de emisión de mayor cociente señal/ruido $(\mathrm{S} / \mathrm{N}$, sigla en inglés de signal-to-noise ratio) han sido medidos como se detalla en el Capítulo 3. Para aquellas líneas donde el cociente $\mathrm{S} / \mathrm{N}$ no es suficiente, el proceso iterativo utilizado para deconvolucionar las diferentes componentes de los perfiles de las líneas no ha dado un resultado significativo. Sobre éstas líneas más débiles y utilizando la tarea ngaussfit de IRAF, se ha copiado la solución encontrada del ajuste realizado en las líneas más intensas con un grado de ionización comparable. Luego, fijando los centros (a la longitud de onda correspondiente de la línea que se quiere ajustar) y anchos de las componentes, sólo se le permite a la tarea variar simultáneamente la amplitud de cada componente.

Se han supuesto dos zonas de ionización: una zona de baja ionización, cuya temperatura característica sería la de [OII] y de donde se emiten las líneas de recombinación de hidrógeno y las líneas prohibidas de [OII], [NII], [SII], y otra de alta ionización caracterizada por la temperatura de [OIII] de donde procederían las emisiones de las líneas prohibidas de [OIII], [NeIII] y las líneas de recombinación del HeI. Se supone que tanto las líneas del [SIII] como las del [ArIII] son emitidas en una zona intermedia a las dos primeras por lo que se han realizado los ajustes a estas líneas utilizando ambas aproximaciones iniciales y así poder ver cuál es la que produce errores más pequeños. En los paneles superiores de las Figuras 4.2 y 4.3 se muestran el plano del Flujo-Velocidad de la línea de emisión más intensa [OIII] $\lambda 5007 \AA$ en los brotes A y B, respectivamente, con las componentes ajustadas al perfil de línea superpuestas. Para mostrar la buena correlación de los ajustes entre los perfiles de línea de emisión intensas contra los perfiles de las líneas con menor señal-ruido, se graficaron en el panel inferior de cada figura un ejemplo del ajuste obtenido para una línea de emisión débil con similar grado de ionización que [ÖII] $\lambda 5007 \AA$. En el brote A, se compara [OIII] $\lambda 5007 \AA$ con HeI $5876 \AA$, mostrando el buen ajuste realizado en esta línea de emisión débil. En el brote B, es notable la buena correlación entre las dos líneas de emisión del oxígeno. Gracias a este proceso es posible ajustar y deconvolucionar la importante y débil línea auroral [OIII] $\lambda 4363 \AA$, la cual es una línea sensible a la temperatura electrónica del medio donde se forma.

Los flujos de las líneas de emisión de los cinco brotes observados son mostrados en la Tabla 4.2 para los datos de ranura larga, y en las Tablas 4.3, 4.4, 4.5, 4.6 y 4.7 para los datos échelle. Cada Tabla lista la intensidad de las líneas de emisión para cada componente corregidas por enrojecimiento, junto a la constante de enrojecimiento $(\mathrm{C}(\mathrm{H} \beta)$ ) y su correspondiente error considerado como la incerteza del ajuste de mínimos cuadrados y la intensidad de $\mathrm{H} \beta$ corregida por enrojecimiento. La columna 1 muestra la longitud de onda y el nombre de la línea medida. En la columna 2, la curva de enrojecimiento adoptada, $\mathrm{f}(\lambda)$, normalizada a $\mathrm{H} \beta$. La columna 3 el ancho equivalente $(\mathrm{EW})$ en $\AA$. En la columna 4 la intensidad de la línea $(I(\lambda))$ corregida por 

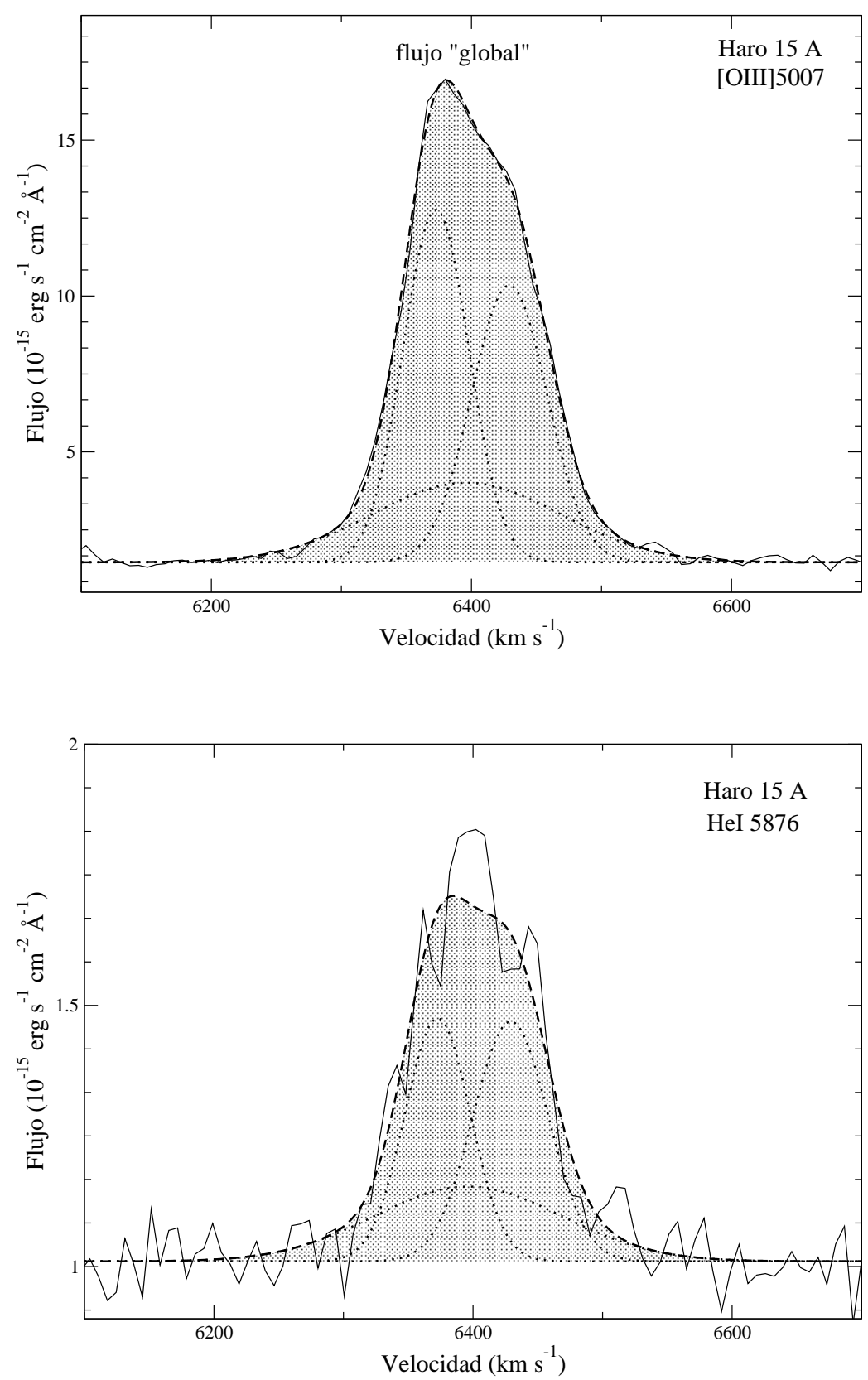

Figura 4.2: Comparación entre las soluciones de distintos ajustes encontrados para una línea intensa y otra débil del brote A 

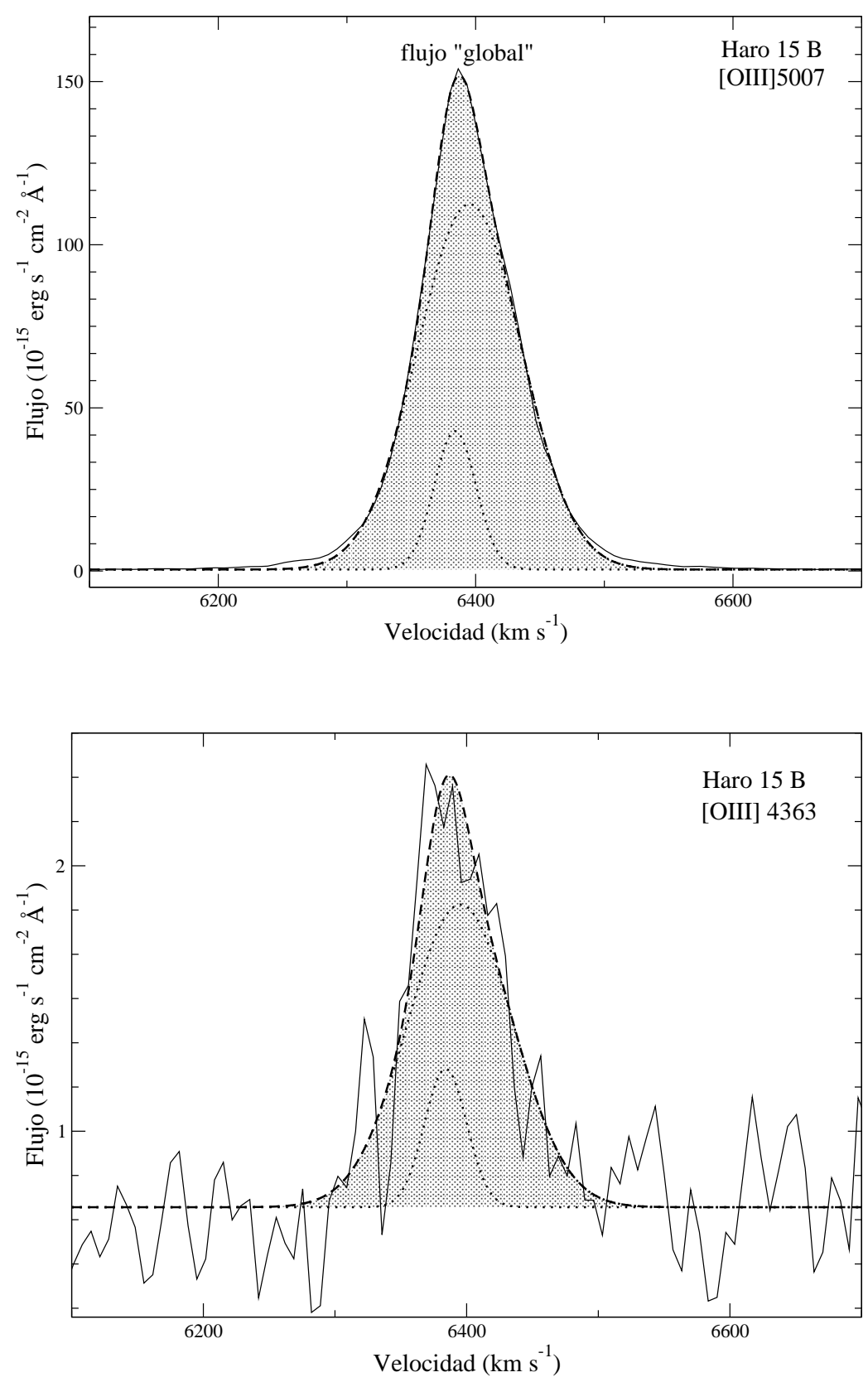

Figura 4.3: Comparación entre las soluciones de distintos ajustes encontrados para una línea intensa y otra débil del brote $\mathbf{B}$ 
enrojecimiento y relativa a $10000 \mathrm{H} \beta$. Los errores relativos en las líneas de emisión listados en la columna 5 se obtuvieron mediante la propagación cuadrática de los errores observacionales en los flujos de las líneas y la incertidumbre en la constante de enrojecimiento. No se han tenido en cuenta los errores de las intensidades teóricas ya que son mucho menores que los errores de observación.

En el espectro de ranura larga para el caso del brote $\mathrm{B}$, todos los parámetros físicos que dependen de la intensidad de la línea [SIII] $\lambda 9532 \AA$ fueron calculados utilizando la relación teórica entre esta línea y la línea [SIII] $\lambda 9069$ A , I(9069) $\approx 2.44 \times \mathrm{I}(9532)$ (Osterbrock, 1989), ya que esta línea está fuera del rango espectral de observación. En el brote $\mathrm{C}$ fue imposible cuantificar una medida de estas líneas. En este caso, no se incluyeron estas líneas ni en las tablas ni en nuestros cálculos. También para este mismo brote, es imposible medir la línea [NiI] $\lambda 6548 \AA$, ya que se solapa con $\mathrm{H} \alpha$. Así que se tuvo que corregir el flujo de $\mathrm{H} \alpha$ de la contaminación proveniente de esta línea de nitrógeno estimando su contribución a partir de $[\mathrm{NII}] \lambda 6584$ A utilizando su relación teórica, I(6584) $\approx 2.9 \cdot \mathrm{I}(6548)$.

Debido al desplazamiento al rojo que presenta esta galaxia, en todos los espectros échelle, la línea [SII] $\lambda 6731$ Å está afectada por la emisión de líneas telúricas de cielo de OH. Entonces, se procedió a utilizar la estrella estandar Feige 110 (sdOB) como estandar telúrica, dado que la misma no presenta líneas estelares en ese rango, que fue observada con la misma masa de aire que la galaxia y que pudo ser muy bien calibrada en flujo. Así es que, haciendo uso de la rutina telluric de IRAF, se pudieron corregir los espectros de los brotes observados en el modo échelle por el efecto que producen las líneas telúricas. Luego esta línea fue ajustada con la tarea ngaussfit copiando la solución del ajuste obtenido para la línea [SII] $\lambda 6717 \AA$, y usando el mismo procedimiento que se ha usado para las líneas de bajo S/N. Luego, este será un importante punto a tener en cuenta al momento de analizar las densidades electrónicas derivadas para las diferentes componentes en estos brotes. Aquellas líneas que presentaban errores relativos en flujo mayores al $45 \%$ no fueron tenidas en cuenta para los cálculos. La única excepción ha sido la línea [OIII] $\lambda 4363 \AA$ en la componente angosta del brote $\mathrm{B}$ que tiene un error mayor al $45 \%$ pero se la consideró para poder cálcular de temperatura del [OIII]. En el brote F, solo se ha podido obtener la medida global dado que las líneas no tienen el suficiente S/N para realizar un ajuste por componentes. En ningún caso fue posible medir las líneas del [OIII] $\lambda \lambda 7319,7330$ Å. Por último, en los brotes C, E y F, debido al bajo S/N de estos tres espectros, las líneas [SIII] $\lambda \lambda$ 9069, $9532 \AA$ no pudieron ser medidas y, por otro lado, el flujo de la línea [OıII] $\lambda 4959 \AA$ fue calculado a partir de la línea [OıII] $\lambda 5007 \AA$ de acuerdo a la relación teórica entre ambas líneas, $\mathrm{I}(5007) \approx 3 \times \mathrm{I}(4959)$ (Osterbrock, 1989).

Para el brote $\mathrm{A}$, no se tuvo en cuenta la línea $\mathrm{H} \delta$ debido a que la misma es muy débil y no puede ser descompuesta en las diferentes componentes cinemáticas. En el brote E, la segunda componente angosta y la medida global presentan un valor de $\mathrm{C}(\mathrm{H} \beta)$ un poco menor a cero, pero compatible con éste dentro de los errores observacionales, por eso fue tomado igual a cero. Además en el brote $\mathrm{F}$, la línea de recombinación $\mathrm{H} \beta$ tiene un bajo cociente $\mathrm{S} / \mathrm{N}$, por lo 
Tabla 4.2: Líneas de emisión medidas en el espectro de ranura larga en los brotes $\mathbf{B} \mathbf{y}$ $\mathbf{C}$ obtenidas para la medida global. Intensidad de la línea corregida por enrojecimiento $[F(H \beta)=I(H \beta)=10000]$

\begin{tabular}{|c|c|c|c|c|c|c|c|}
\hline \multirow[b]{2}{*}{$\lambda(\AA)$} & \multirow[b]{2}{*}{$f(\lambda)$} & \multicolumn{3}{|c|}{$\mathrm{B}$} & \multicolumn{3}{|c|}{$\mathrm{C}$} \\
\hline & & $\begin{array}{c}-\mathrm{EW} \\
(\AA)\end{array}$ & $I(\lambda)$ & $\begin{array}{c}\text { Error } \\
(\%)\end{array}$ & $\begin{array}{c}-\mathrm{EW} \\
(\AA)\end{array}$ & $I(\lambda)$ & $\begin{array}{c}\text { Error } \\
(\%)\end{array}$ \\
\hline $3727[\mathrm{OII}]^{a}$ & 0.271 & 109.1 & $11943 \pm 117$ & 1.0 & 45.3 & $25406 \pm 2104$ & 8.3 \\
\hline 3835 H9 & 0.246 & 3.8 & $465 \pm 23$ & 5.0 & $\ldots$ & $\ldots$ & $\ldots$ \\
\hline 3868 [NeIII] & 0.238 & 34.0 & $4494 \pm 11$ & 0.2 & $\ldots$ & $\ldots$ & $\ldots$ \\
\hline $3889 \mathrm{HeI}+\mathrm{H} 8$ & 0.233 & 9.4 & $1263 \pm 65$ & 5.1 & $\ldots$ & $\ldots$ & $\ldots$ \\
\hline $3970[\mathrm{NeIII}]+\mathrm{H} \epsilon$ & 0.215 & 21.1 & $2535 \pm 4$ & 0.2 & $\ldots$ & $\ldots$ & $\ldots$ \\
\hline $4068[\mathrm{SII}]$ & 0.195 & 0.7 & $87 \pm 17$ & 19.6 & $\ldots$ & $\ldots$ & $\ldots$ \\
\hline $4102 \mathrm{H} \delta$ & 0.188 & 21.1 & $2395 \pm 31$ & 1.3 & $\ldots$ & $\ldots$ & $\ldots$ \\
\hline $4340 \mathrm{H} \gamma$ & 0.142 & 41.5 & $4483 \pm 17$ & 0.4 & 6.0 & $3853 \pm 657$ & 17.1 \\
\hline 4363 [OіII] & 0.138 & 6.3 & $694 \pm 42$ & 6.0 & $\ldots$ & $\ldots$ & $\ldots$ \\
\hline 4471 НеI & 0.106 & 2.8 & $311 \pm 16$ & 5.2 & 3.8 & $2842 \pm 566$ & 19.9 \\
\hline 4658 [FeIII] & 0.053 & 0.3 & $36 \pm 6$ & 17.8 & $\ldots$ & $\ldots$ & $\ldots$ \\
\hline 4686 HeII & 0.045 & 1.5 & $154 \pm 19$ & 12.1 & 1.6 & $1261 \pm 330$ & 26.1 \\
\hline $4713[$ ArIV $]+\mathrm{HeI}$ & 0.038 & 0.6 & $64 \pm 7$ & 11.4 & $\ldots$ & $\ldots$ & $\ldots$ \\
\hline $4740[$ ArIV $]$ & 0.031 & 0.9 & $87 \pm 12$ & 14.1 & $\ldots$ & $\ldots$ & $\ldots$ \\
\hline $4861 \mathrm{H} \beta$ & 0.000 & 114.1 & $10000 \pm 25$ & 0.2 & 14.6 & $10000 \pm 541$ & 5.4 \\
\hline 4959 [Оіні] & -0.024 & 221.3 & $21220 \pm 77$ & 0.4 & 8.3 & $6682 \pm 209$ & 3.1 \\
\hline 5007 [OiII] & -0.035 & 539.1 & $51342 \pm 88$ & 0.2 & 27.9 & $22042 \pm 467$ & 2.1 \\
\hline 5876 HeI & -0.209 & 22.5 & $1235 \pm 28$ & 2.3 & $\ldots$ & $\ldots$ & $\ldots$ \\
\hline $6300[\mathrm{OI}]$ & -0.276 & 6.8 & $366 \pm 16$ & 4.3 & 2.5 & $1542 \pm 295$ & 19.1 \\
\hline 6312 [SIII] & -0.278 & 2.3 & $118 \pm 18$ & 15.5 & $\ldots$ & $\ldots$ & $\cdots$ \\
\hline $6364[\mathrm{OI}]$ & -0.285 & 2.2 & $117 \pm 11$ & 9.6 & $\ldots$ & . & $\ldots$ \\
\hline $6548[\mathrm{NII}]$ & -0.311 & 8.3 & $416 \pm 20$ & 4.8 & $\ldots$ & $\ldots$ & $\ldots$ \\
\hline $6563 \mathrm{H} \alpha$ & -0.313 & 565.8 & $27618 \pm 36$ & 0.1 & 52.6 & $28500 \pm 824$ & 2.9 \\
\hline $6584[\mathrm{NII}]$ & -0.316 & 23.4 & $1175 \pm 22$ & 1.8 & 5.8 & $3230 \pm 372$ & 11.5 \\
\hline 6678 HeI & -0.329 & 5.5 & $264 \pm 13$ & 4.7 & $\ldots$ & $\ldots$ & $\ldots$ \\
\hline 6717 [SII] & -0.334 & 32.1 & $1453 \pm 24$ & 1.7 & 10.2 & $5209 \pm 613$ & 11.8 \\
\hline 6731 [SII] & -0.336 & 13.7 & $617 \pm 49$ & 8.0 & 5.1 & $2609 \pm 493$ & 18.9 \\
\hline 7065 HeI & -0.377 & 6.3 & $251 \pm 18$ & 7.2 & $\ldots$ & $\ldots$ & $\ldots$ \\
\hline 7136 [ArIII] & -0.385 & 19.4 & $707 \pm 21$ & 3.0 & $\ldots$ & $\ldots$ & $\ldots$ \\
\hline $7281 \mathrm{HeI}^{b}$ & -0.402 & 1.1 & $42 \pm 5$ & 11.9 & $\ldots$ & $\ldots$ & $\ldots$ \\
\hline 7319 [Оіг] ${ }^{c}$ & -0.406 & 4.0 & $148 \pm 6$ & 3.9 & $\ldots$ & $\ldots$ & $\ldots$ \\
\hline $7330[\mathrm{OII}]^{d}$ & -0.407 & 3.1 & $116 \pm 4$ & 3.2 & $\ldots$ & $\cdots$ & $\ldots$ \\
\hline 7751 [ArIII] & -0.451 & 5.8 & $186 \pm 13$ & 7.0 & $\ldots$ & $\ldots$ & $\ldots$ \\
\hline 9069 [SIII] & -0.561 & 69.9 & $1202 \pm 118$ & 9.8 & $\ldots$ & $\ldots$ & $\ldots$ \\
\hline $\mathrm{I}(\mathrm{H} \beta)^{*}$ & & & $4.49 \times 10^{-14}$ & & & $0.11 \times 10^{-14}$ & \\
\hline $\mathrm{c}(\mathrm{H} \beta)$ & & & $0.29 \pm 0.01$ & & & $0.24 \pm 0.12$ & \\
\hline
\end{tabular}




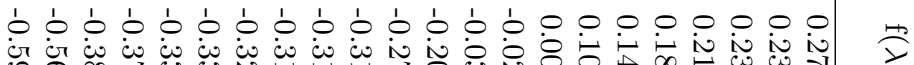

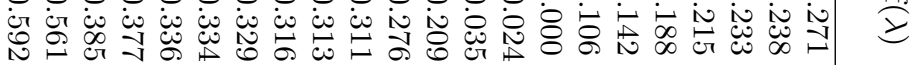

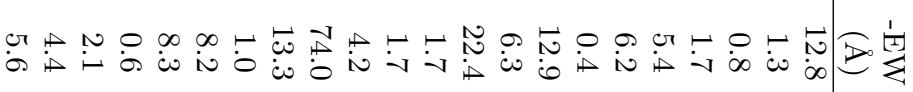

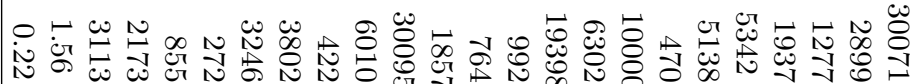

H $\times$ H H H H H H H H H H H H H H H H H H H H H H

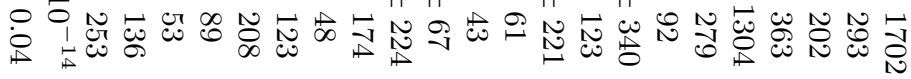

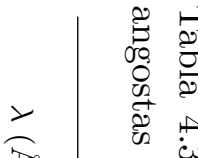

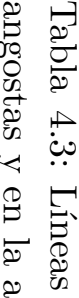

¿ี

胥

$\stackrel{8}{8}$

䒠葛.

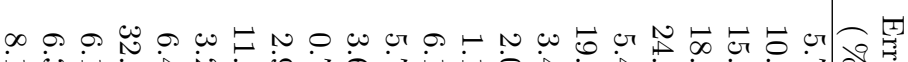

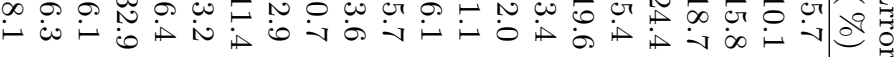

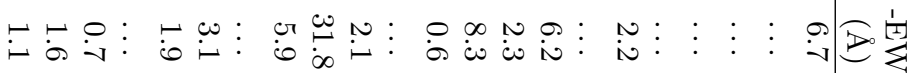

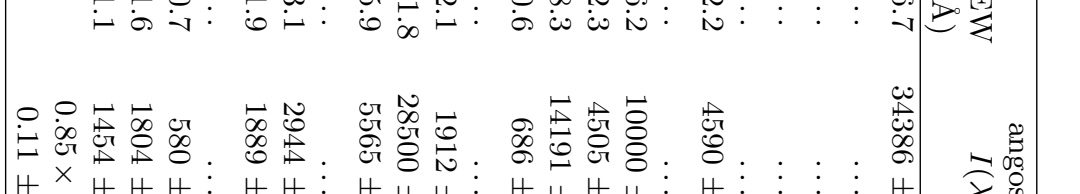

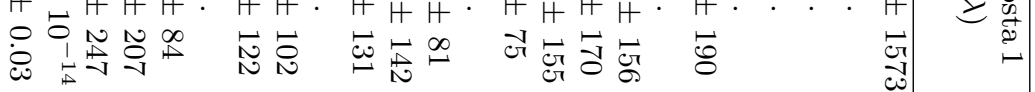

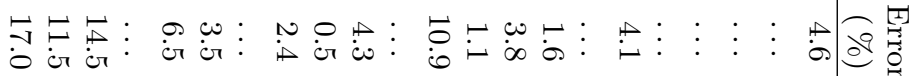

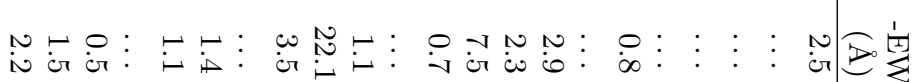

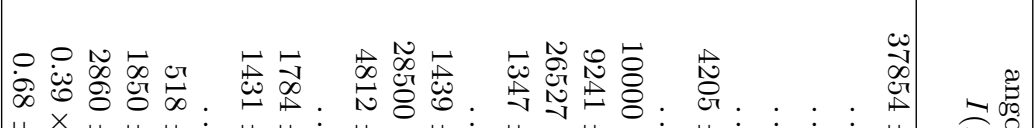

H ${ }^{X}$ H H H: H H: H H H: H H H H: H: $:$ : : H

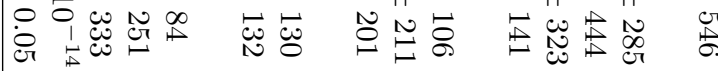

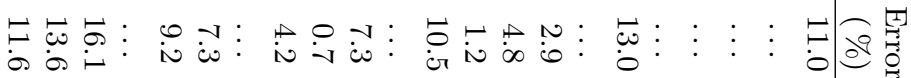

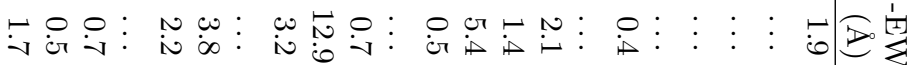

8

8

8

(ึ)

옹. 
Tabla 4.4: Líneas de emisión medidas en el espectro échelle en el brote $\mathbf{B}$ obtenidas en la medida global, y en la componente angosta y en la ancha. Intensidad de la línea corregida por enrojecimiento $[F(H \beta)=I(H \beta)=10000]$

\begin{tabular}{|c|c|c|c|c|c|c|c|c|c|c|}
\hline \multirow[b]{2}{*}{$\lambda(\AA)$} & \multirow[b]{2}{*}{$\mathrm{f}(\lambda)$} & \multicolumn{3}{|c|}{ global } & \multicolumn{3}{|c|}{ angosta } & \multicolumn{3}{|c|}{ ancha } \\
\hline & & $\begin{array}{c}-\mathrm{EW} \\
(\AA)\end{array}$ & $I(\lambda)$ & $\begin{array}{c}\text { Error } \\
(\%)\end{array}$ & $\begin{array}{c}-\mathrm{EW} \\
(\AA)\end{array}$ & $I(\lambda)$ & $\begin{array}{c}\text { Error } \\
(\%)\end{array}$ & $\begin{array}{c}-\mathrm{EW} \\
(\AA)\end{array}$ & $I(\lambda)$ & $\begin{array}{c}\text { Error } \\
(\%)\end{array}$ \\
\hline $3727[\mathrm{OII}]^{a}$ & 0.271 & 20.4 & $9049 \pm 236$ & 2.6 & 8.1 & $24096 \pm 854$ & 3.5 & 8.0 & $5877 \pm 310$ & 5.3 \\
\hline 3835 H9 & 0.246 & 1.0 & $358 \pm 16$ & 4.4 & $\ldots$ & $\ldots$ & $\ldots$ & $\ldots$ & $\ldots$ & $\ldots$ \\
\hline 3868 [NeIII] & 0.238 & 12.4 & $5585 \pm 184$ & 3.3 & 1.6 & $4214 \pm 649$ & 15.4 & 8.4 & $5845 \pm 271$ & 4.6 \\
\hline $3889 \mathrm{HeI}+\mathrm{H} 8$ & 0.233 & 5.1 & $1571 \pm 40$ & 2.6 & $\ldots$ & $\ldots$ & $\ldots$ & $\ldots$ & $\ldots$ & $\ldots$ \\
\hline $3968[\mathrm{NeIII}]+\mathrm{H} 7$ & 0.216 & 5.2 & $1498 \pm 30$ & 2.0 & 0.5 & $1016 \pm 375$ & 36.9 & 2.8 & $1501 \pm 163$ & 10.8 \\
\hline $3970[\mathrm{NeIII}]+\mathrm{H} \epsilon$ & 0.215 & 3.8 & $1062 \pm 57$ & 5.3 & 1.2 & $1626 \pm 242$ & 14.9 & 3.4 & $1260 \pm 104$ & 8.2 \\
\hline $4102 \mathrm{H} \delta$ & 0.188 & 9.7 & $2766 \pm 118$ & 4.3 & 1.4 & $2219 \pm 338$ & 15.2 & 5.7 & $2534 \pm 113$ & 4.5 \\
\hline $4340 \mathrm{H} \gamma$ & 0.142 & 37.8 & $4827 \pm 122$ & 2.5 & 5.6 & $5305 \pm 159$ & 3.0 & 16.7 & $4434 \pm 56$ & 1.3 \\
\hline 4363 [OIII] & 0.138 & 4.4 & $783 \pm 127$ & 16.3 & 0.4 & $465 \pm 213$ & 45.8 & 2.4 & $720 \pm 90$ & 12.5 \\
\hline $4471 \mathrm{HeI}$ & 0.106 & 3.0 & $471 \pm 17$ & 3.6 & $\ldots$ & $\ldots$ & $\ldots$ & $\ldots$ & $\ldots$ & $\ldots$ \\
\hline $4713[$ ArIV $]+\mathrm{HeI}$ & 0.038 & 2.6 & $336 \pm 28$ & 8.4 & $\ldots$ & $\ldots$ & $\ldots$ & $\ldots$ & $\ldots$ & $\ldots$ \\
\hline $4861 \mathrm{H} \beta$ & 0.000 & 81.3 & $10000 \pm 98$ & 1.0 & 14.1 & $10000 \pm 157$ & 1.6 & 45.6 & $10000 \pm 65$ & 0.7 \\
\hline 4959 [Оіні] & -0.024 & 130.0 & $22714 \pm 175$ & 0.8 & 16.7 & $14958 \pm 286$ & 1.9 & 91.0 & $25569 \pm 150$ & 0.6 \\
\hline 5007 [ÖIі] & -0.035 & 470.0 & $69812 \pm 213$ & 0.3 & 35.0 & $37507 \pm 795$ & 2.1 & 233.8 & $79550 \pm 336$ & 0.4 \\
\hline $5876 \mathrm{HeI}$ & -0.209 & 12.4 & $1053 \pm 9$ & 0.9 & 1.7 & $571 \pm 37$ & 6.5 & 10.2 & $1237 \pm 20$ & 1.6 \\
\hline $6300[\mathrm{OI}]$ & -0.276 & 2.7 & $181 \pm 8$ & 4.4 & 2.0 & $501 \pm 38$ & 7.5 & 0.8 & $73 \pm 22$ & 30.3 \\
\hline 6312 [SIII] & -0.278 & 1.8 & $125 \pm 25$ & 20.2 & 0.7 & $195 \pm 43$ & 22.2 & 1.0 & $103 \pm 25$ & 24.1 \\
\hline 6548 [NiI] & -0.311 & 2.4 & $185 \pm 5$ & 2.6 & 1.6 & $422 \pm 24$ & 5.7 & 1.6 & $158 \pm 21$ & 13.0 \\
\hline $6563 \mathrm{H} \alpha$ & -0.313 & 358.0 & $28618 \pm 40$ & 0.1 & 73.5 & $29349 \pm 267$ & 0.9 & 184.8 & $28008 \pm 130$ & 0.5 \\
\hline $6584[\mathrm{NII}]$ & -0.316 & 7.7 & $623 \pm 12$ & 1.9 & 6.0 & $1573 \pm 53$ & 3.4 & 4.0 & $404 \pm 25$ & 6.2 \\
\hline $6678 \mathrm{HeI}$ & -0.329 & 4.8 & $320 \pm 3$ & 1.1 & 0.5 & $129 \pm 27$ & 20.7 & 4.6 & $427 \pm 16$ & 3.8 \\
\hline 6717 [SII] & -0.334 & 10.6 & $728 \pm 10$ & 1.3 & 7.4 & $1921 \pm 46$ & 2.4 & 3.6 & $362 \pm 29$ & 8.1 \\
\hline 6731 [SII] & -0.336 & 8.4 & $585 \pm 22$ & 3.8 & 5.2 & $1405 \pm 53$ & 3.8 & 2.6 & $270 \pm 34$ & 12.6 \\
\hline $7065 \mathrm{HeI}$ & -0.377 & 4.9 & $293 \pm 6$ & 1.9 & $\ldots$ & $\ldots$ & $\ldots$ & $\ldots$ & $\ldots$ & $\ldots$ \\
\hline 7136 [ArıII] & -0.385 & 11.0 & $705 \pm 9$ & 1.3 & 4.0 & $976 \pm 52$ & 5.3 & 6.9 & $666 \pm 23$ & 3.4 \\
\hline 7751 [ArIII] & -0.451 & 3.2 & $196 \pm 13$ & 6.4 & $\ldots$ & $\ldots$ & $\ldots$ & $\ldots$ & $\ldots$ & $\ldots$ \\
\hline 9069 [SIII] & -0.561 & 13.9 & $1193 \pm 111$ & 9.3 & 3.1 & $1007 \pm 136$ & 13.5 & 9.2 & $1325 \pm 90$ & 6.8 \\
\hline 9532 [SıII] & -0.592 & 21.3 & $2510 \pm 141$ & 5.6 & 6.9 & $2885 \pm 185$ & 6.4 & 13.1 & $2488 \pm 125$ & 5.0 \\
\hline $\mathrm{I}(\mathrm{H} \beta)^{*}$ & & & $3.16 \times 10^{-14}$ & & & $0.74 \times 10^{-14}$ & & & $2.40 \times 10^{-14}$ & \\
\hline $\mathrm{c}(\mathrm{H} \beta)$ & & & $0.13 \pm 0.01$ & & & $0.36 \pm 0.02$ & & & $0.07 \pm 0.01$ & \\
\hline
\end{tabular}

\footnotetext{
* $\operatorname{erg~seg}{ }^{-1} \mathrm{~cm}^{-2}$
} 


\section{CAPÍTULO 4. ESPECTROSCOPÍA DE ALTA RESOLUCIÓN DE LA GALAXIA BCD}

64 HARO 15: DETERMINACIÓN DE ABUNDANCIAS

Tabla 4.5: Líneas de emisión medidas en el espectro échelle en brote $\mathbf{C}$ obtenidas en la medida global, y en la componente angosta y en la ancha. Intensidad de la línea corregida por enrojecimiento $[F(H \beta)=I(H \beta)=10000]$

\begin{tabular}{|c|c|c|c|c|c|c|c|c|c|c|}
\hline$\lambda(\AA)$ & $\mathrm{f}(\lambda)$ & $\begin{array}{c}-\mathrm{EW} \\
(\AA)\end{array}$ & $\begin{array}{l}\text { global } \\
I(\lambda)\end{array}$ & $\begin{array}{c}\text { Error } \\
(\%)\end{array}$ & $\begin{array}{c}-\mathrm{EW} \\
(\AA)\end{array}$ & $\begin{array}{c}\text { angosta } \\
I(\lambda)\end{array}$ & $\begin{array}{c}\text { Error } \\
(\%)\end{array}$ & $\begin{array}{c}\text {-EW } \\
(\AA)\end{array}$ & $\begin{array}{l}\text { ancha } \\
I(\lambda)\end{array}$ & $\begin{array}{c}\text { Error } \\
(\%)\end{array}$ \\
\hline $4861 \mathrm{H} \beta$ & 0.000 & 3.2 & $10000 \pm 2188$ & 21.9 & 1.0 & $10000 \pm 1464$ & 14.6 & 1.1 & $10000 \pm 2349$ & 23.5 \\
\hline 4959 [Оіні] & -0.024 & 5.6 & $6879 \pm 391$ & 5.7 & 3.4 & $9818 \pm 508$ & 5.2 & 2.0 & $5245 \pm 612$ & 11.7 \\
\hline 5007 [Оiн] & -0.035 & 5.6 & $20467 \pm 1265$ & 6.2 & 3.4 & $29371 \pm 1584$ & 5.4 & 2.0 & $15582 \pm 1859$ & 11.9 \\
\hline $6563 \mathrm{H} \alpha$ & -0.313 & 18.1 & $28500 \pm 1148$ & 4.0 & 6.5 & $28500 \pm 709$ & 2.5 & 8.0 & $28500 \pm 799$ & 2.8 \\
\hline $6584[\mathrm{NII}]$ & -0.316 & 1.3 & $2334 \pm 740$ & 31.7 & 0.9 & $3852 \pm 942$ & 24.4 & 0.4 & $1412 \pm 588$ & 41.7 \\
\hline 6717 [SII] & -0.334 & 2.6 & $5015 \pm 1591$ & 31.7 & 1.2 & $5400 \pm 1357$ & 25.1 & 1.4 & $5316 \pm 1890$ & 35.6 \\
\hline 6731 [SII] & -0.336 & 1.8 & $2891 \pm 1071$ & 37.0 & 0.7 & $3186 \pm 1295$ & 40.6 & 1.0 & $3891 \pm 1606$ & 41.3 \\
\hline $\mathrm{I}(\mathrm{H} \beta)^{*}$ & & & $0.08 \times 10^{-14}$ & & & $0.04 \times 10^{-14}$ & & & $0.04 \times 10^{-14}$ & \\
\hline $\mathrm{c}(\mathrm{H} \beta)$ & & & $0.21 \pm 0.40$ & & & $0.14 \pm 0.25$ & & & $0.38 \pm 0.41$ & \\
\hline
\end{tabular}

Tabla 4.6: Líneas de emisión medidas en el espectro échelle en brote $\mathbf{E}$ obtenidas en la medida global, y en la componentes angostas. Intensidad de la línea corregida por enrojecimiento $[F(H \beta)=I(H \beta)=10000]$

\begin{tabular}{|c|c|c|c|c|c|c|c|c|c|c|}
\hline$\lambda(\AA)$ & $\mathrm{f}(\lambda)$ & $\begin{array}{c}-\mathrm{EW} \\
(\AA)\end{array}$ & $\begin{array}{l}\text { global } \\
I(\lambda)\end{array}$ & $\begin{array}{c}\text { Error } \\
(\%)\end{array}$ & $\begin{array}{c}-\mathrm{EW} \\
(\AA)\end{array}$ & $\begin{array}{c}\text { angosta } 1 \\
I(\lambda)\end{array}$ & $\begin{array}{c}\text { Error } \\
(\%)\end{array}$ & $\begin{array}{c}-\mathrm{EW} \\
(\AA)\end{array}$ & $\begin{array}{c}\text { angosta } 2 \\
I(\lambda)\end{array}$ & $\begin{array}{c}\text { Error } \\
(\%)\end{array}$ \\
\hline $3727[\text { OII }]^{a}$ & 0.271 & 8.2 & $32110 \pm 9745$ & 30.3 & $\ldots$ & $\ldots$ & $\ldots$ & $\ldots$ & $\ldots$ & $\ldots$ \\
\hline $4861 \mathrm{H} \beta$ & 0.000 & 7.5 & $10000 \pm 1530$ & 15.3 & 1.8 & $10000 \pm 1267$ & 12.7 & 1.9 & $10000 \pm 1816$ & 18.2 \\
\hline 4959 [Оіні] & -0.024 & 2.9 & $5747 \pm 729$ & 12.7 & 2.2 & $3443 \pm 351$ & 10.2 & 4.4 & $6900 \pm 383$ & 5.6 \\
\hline 5007 [Оіні] & -0.035 & 6.9 & $12160 \pm 921$ & 7.6 & 2.2 & $10157 \pm 1047$ & 10.3 & 4.4 & $20671 \pm 1214$ & 5.9 \\
\hline $5876 \mathrm{HeI}$ & -0.209 & 1.6 & $1733 \pm 561$ & 32.4 & $\ldots$ & $\ldots$ & $\ldots$ & $\ldots$ & $\ldots$ & $\ldots$ \\
\hline $6300[\mathrm{OI}]$ & -0.276 & 2.1 & $2017 \pm 563$ & 27.9 & $\ldots$ & $\ldots$ & $\ldots$ & $\ldots$ & $\ldots$ & $\ldots$ \\
\hline 6548 [NII] & -0.311 & 1.4 & $1419 \pm 468$ & 33.0 & $\ldots$ & $\ldots$ & $\ldots$ & $\ldots$ & $\ldots$ & $\ldots$ \\
\hline $6563 \mathrm{H} \alpha$ & -0.313 & 32.0 & $28500 \pm 1087$ & 3.8 & 15.9 & $28500 \pm 637$ & 2.2 & 11.0 & $28500 \pm 964$ & 3.4 \\
\hline 6584 [NII] & -0.316 & 5.8 & $5268 \pm 1157$ & 22.0 & 1.7 & $2810 \pm 620$ & 22.0 & 3.7 & $9025 \pm 2224$ & 24.6 \\
\hline 6717 [SII] & -0.334 & 6.0 & $6212 \pm 1443$ & 23.2 & 1.4 & $2509 \pm 512$ & 20.4 & 4.3 & $11233 \pm 2878$ & 25.6 \\
\hline 6731 [SII] & -0.336 & 5.2 & $4448 \pm 1400$ & 31.5 & 0.8 & $1875 \pm 789$ & 42.1 & 1.8 & $6636 \pm 2630$ & 39.6 \\
\hline $\mathrm{I}(\mathrm{H} \beta)^{*}$ & & & $0.18 \times 10^{-14}$ & & & $0.07 \times 10^{-14}$ & & & $0.07 \times 10^{-14}$ & \\
\hline $\mathrm{c}(\mathrm{H} \beta)$ & & & 0.00 & & & $0.59 \pm 0.22$ & & & 0.00 & \\
\hline
\end{tabular}


Tabla 4.7: Líneas de emisión medidas en el espectro échelle en brote $\mathbf{F}$ obtenidas en la medida global. Intensidad de la línea $[F(H \beta)=I(H \beta)=10000]$. ${ }^{\dagger}$ Las líneas no fueron corregidas por enrojecimiento, ver texto

\begin{tabular}{lcccc}
\hline \multicolumn{1}{c}{$\lambda(\AA)$} & $\mathrm{f}(\lambda)$ & $\begin{array}{c}\text {-EW } \\
(\AA)\end{array}$ & $\begin{array}{c}\text { global } \\
F(\lambda)\end{array}$ & $\begin{array}{c}\text { Error } \\
(\%)\end{array}$ \\
\hline $4861 \mathrm{H} \beta$ & 0.000 & -2.5 & $10000 \pm 3213$ & 32.1 \\
$4959[\mathrm{OIII}]$ & -0.024 & -1.2 & $7274 \pm 597$ & 8.2 \\
$5007[\mathrm{OIII}]$ & -0.035 & -3.6 & $21797 \pm 1981$ & 9.1 \\
$6563 \mathrm{H} \alpha$ & -0.313 & -10.6 & $28500 \pm 2593$ & 9.1 \\
$6584[\mathrm{NII}]$ & -0.316 & -1.1 & $3415 \pm 2153$ & 63.0 \\
$6717[\mathrm{SII}]$ & -0.334 & -2.6 & $7317 \pm 4024$ & 55.0 \\
$6731[\mathrm{SII}]$ & -0.336 & -3.1 & $9011 \pm 5317$ & 59.0 \\
\hline $\mathrm{F}(\mathrm{H} \beta)^{*}$ & & & $0.04 \times 10^{-14}$ \\
$\mathrm{c}(\mathrm{H} \beta)$ & & \multicolumn{3}{c}{} \\
\hline$* \operatorname{erg~seg}{ }^{-1} \mathrm{~cm}^{-2}$ & & & \\
\hline
\end{tabular}

tanto las intensidades de las líneas en este brote no fueron corregidas por enrojecimiento.

\subsection{Análisis de Abundancias}

La espectrocopía es una poderosa herramienta que permite la determinación de las abundancias de regiones Hir en el Universo Local haciendo uso de los métodos basados en la medición de las intensidades de las líneas de emisión y en la física atómica. Esto es bien conocido como el método "directo". En el caso de las galaxias más distantes o intrínsecamente débiles, el bajo cociente $\mathrm{S} / \mathrm{N}$ obtenido con los telescopios actuales se contrapone a la aplicación de este método y por ello es necesario la aplicación de métodos empíricos, los cuales se basan en las líneas de emisión más intensas. La base fundamental de estos métodos empíricos se conoce bastante bien (ver por ejemplo Pérez-Montero \& Díaz 2005). La exactitud de los resultados dependerá de la bondad de su calibración, que a su vez depende de un conjunto de abundancias derivadas con precisión a travéz del método "directo" para que el proceso de interpolación sea fiable.

Sin embargo, derivar de forma precisa las abundancias de cada elemento no es un asunto sencillo. En primer lugar, porque es necesario medir las líneas de emisión con exactitud. Y en segundo lugar, porque se requiere de un cierto conocimiento de la estructura de ionización de la región con el fin de obtener las abundancias iónicas de los diferentes elementos y, en algunos casos, se necesita de los modelos de fotoionización para corregir los estados de ionización inobservables en el rango espectral en cuestión. Para ello es necesario cubrir un amplio rango espectral que incluya desde las líneas del ultravioleta, el doblete de [OII] $\lambda \lambda 3727,3729 \AA$, hasta 
Tabla 4.8: Cocientes utilizados para derivar las densidades y temperaturas electrónicas

\begin{tabular}{ll}
\hline & Cociente de líneas \\
\hline$n_{e}[\mathrm{SII}]$ & $R_{S 2}=\mathrm{I}(6717) / \mathrm{I}(6731)$ \\
$T_{e}[\mathrm{OIII}]$ & $R_{O 3}=\mathrm{I}(4959,5007) / \mathrm{I}(4363)$ \\
$T_{e}[\mathrm{OII}]$ & $R_{O 2}=\mathrm{I}(3727) / \mathrm{I}(7319,7330)$ \\
$T_{e}[\mathrm{SIII}]$ & $R_{S 3}=\mathrm{I}(9069,9532) / \mathrm{I}(6312)$ \\
$T_{e}[\mathrm{SII}]$ & $R_{S 2}^{\prime}=\mathrm{I}(6717,6731) / \mathrm{I}(4068,4076)$ \\
$T_{e}[\mathrm{NII}]$ & $R_{N 2}=\mathrm{I}(6548,6584) / \mathrm{I}(5755)$ \\
\hline
\end{tabular}

el infrarrojo, con el doblete [SIII] $\lambda \lambda$ 9069,9532 A. Para tener un diagnóstico preciso del medio se requiere de la medición de las líneas débiles aurorales. Y además, la precisión en la medición de los cocientes entre estas líneas aurorales y las líneas de recombinación de Balmer debe ser superior al 5\%, ya que en general, estas líneas son débiles, alrededor del $1 \%$ de la intensidad $\mathrm{H} \beta$. Estos requerimientos permiten derivar las diferentes temperaturas de líneas: $\mathrm{T}_{e}([\mathrm{OIII}])$, $\mathrm{T}_{e}([\mathrm{OII}]), \mathrm{T}_{e}([\mathrm{SIII}]), \mathrm{T}_{e}([\mathrm{SII}]), \mathrm{T}_{e}([\mathrm{NII}])$, necesarias para estudiar la estructura de temperatura y la ionización de cada brote o galaxia H II considerados como una región ionizada multizona.

En esta sección serán explicados los diferentes métodos utilizados para estimar las densidades y temperaturas electrónicas con las que luego serán derivadas las abundancias iónicas y totales de las principales especies químicas presentes en las regiones H in de Haro 15. Las condiciones físicas del gas como las abundancias químicas son derivadas y analizadas para cada brote de formación estelar (medida global) y para cada componente cinemática estudiada en el Capítulo 3. Se realizará todo este análisis siguiendo el procedimiento descripto en Hägele et al. (2008) y que se describirá a continuación.

\subsubsection{Propiedades físicas del gas ionizado}

Las propiedades físicas del gas ionizado, como las densidades y temperaturas electrónicas, pueden ser determinadas a partir de los cocientes de los flujos de las líneas observadas de algunos iones. Según Osterbrock (1989), la temperatura puede ser calculada a partir del cociente de transiciones colisionales con energía similar pero originadas en diferentes niveles. El ajuste entre este cociente y la temperatura electrónica se ha obtenido utilizando la tarea temden de IRAF. Dicha tarea está basada en un modelo de equilibrio estadístico de un átomo de 5 niveles (De Robertis et al., 1987; Shaw \& Dufour, 1995). Las probabilidades de transición y niveles de energía son los que dicho programa trae por defecto. Como fuente de error de las densidades y temperaturas se han tomado las incertezas asociadas a la medición de los flujos de las línea de emisión y la corrección de enrojecimiento, y han sido propagados a través de nuestros cálculos. Los coeficientes atómicos de colisión adoptados son los mismos que en el trabajo de Hägele et al. (2008) (ver Tabla 2.5 de dicho trabajo). En la Tabla 4.8 se muestran los cocientes de líneas de emisión necesarios para calcular las densidades y cada temperatura. 


\section{Densidades electrónicas}

El valor de la densidad electrónica, $\mathrm{N}_{e}$, fue determinado a partir del cociente $R_{S 2}$ de las líneas [SII] $\lambda \lambda 6717,6731 \AA$, el cual es el más usado para determinar la densidad electrónica en la zona de baja excitación del gas ionizado. Aquí abajo se muestra la expresión para calcular las densidad a partir del mejor ajuste encontrado entre el cociente y la temperatura electrónica:

$$
n([S \mathrm{II}])=10^{3} \cdot \frac{R_{S 2} \cdot a_{0}(t)+a_{1}(t)}{R_{S 2} \cdot a_{2}(t)+a_{3}(t)}
$$

donde

$$
\begin{gathered}
a_{0}(t)=2,21-1,3 / t-1,25 t+0,23 t^{2} \\
a_{1}(t)=-3,35+1,94 / t+1,93 t-0,36 t^{2} \\
a_{2}(t)=-4,33+2,33 / t+2,72 t-0,57 t^{2} \\
a_{3}(t)=1,84-1 / t-1,14 t+0,24 t^{2}
\end{gathered}
$$

donde $\mathrm{n}([\mathrm{SII}])=\mathrm{n}_{e}=10^{-4} \mathrm{~N}_{e} \mathrm{y} t$ suele ser generalmente, $\mathrm{t}_{e}([\mathrm{OIII}])$, donde $\mathrm{t}_{e}=10^{-4} \mathrm{~T}_{e}$, aunque se puede hacer un proceso iterativo para calcular con $t_{e}([\mathrm{SII}])$, ya que esta temperatura, al igual que ocurre a con $t_{e}([\mathrm{OII}])$, al ser un ion de tipo $\mathrm{np}^{3}$ depende de la densidad. En este caso el cociente que se debe utilizar es el $\mathrm{R}_{S 2}^{\prime}$.

Las densidades derivadas en los brotes, tanto para las medidas globales (datos de ranura larga y del échelle), como para cada componente (datos échelle) pueden ser enmarcadas en el límite de baja densidad $\left(\mathrm{n}_{e} \leq 500 \mathrm{~cm}^{-3}\right)$, excepto en unos pocos casos donde la densidad presenta un error grande. Estos casos serán discutidos más adelante.

En la Sección 4.5 se tratará cada caso en particular.

\section{Temperaturas electrónicas}

Dado que las temperaturas electrónicas son cantidades físicas importantes para la determinación de las abundancias químicas del gas ionizado, es necesario derivar su valor para poder obtener una estimación de la metalicidad del medio donde se forman las líneas de emisión. Sin embargo, en ocasiones, las líneas aurorales sensibles a la temperatura no son detectadas en el espectro de emisión de la nebulosa como ocurre, por ejemplo, en las regiones ricas en oxígeno, donde la línea auroral del [OIII] $\lambda 4363 \AA$ es muy débil y difícil de detectar (Díaz et al., 2007). En general, este hecho puede deberse a una mala relación señal-ruido del espectro o a una elevada metalicidad del gas que produce un enfriamiento tan eficaz que la temperatura es muy baja. En este último caso, las líneas no son detectables debido a que sus flujos son inversamente proporcionales a la exponencial de la temperatura y son intrínsecamente débiles. Existen alternativas que consisten en la determinación de la abundancia del oxígeno haciendo 
uso de las calibraciones empíricas con las líneas de emisión intensas fácilmente observables. En este trabajo se ha encontrado que varias de las regiones observadas en Haro 15 no presentan una o varias de las líneas aurorales necesarias para derivar las temperaturas con el método directo. Es por eso que a continuación se detallan separadamente las diferentes vías por las que uno puede optar para derivar las temperaturas, tanto por el método directo o recurriendo a los diferentes modelos teóricos o relaciones empíricas disponibles en la literatura, los cuales predicen relaciones entre temperaturas electrónicas y distintos parámetros empíricos y las temperaturas.

La temperatura electrónia está definida como la temperatura de la distribución de MaxwellBoltzmann asociada a las velocidades de los electrones que siguen dicha distribución. Entonces, por convención, cada vez que se escriba el término "temperatura" o "temperatura de línea" estaremos refiriéndonos al valor aproximado de la temperatura determinada por la energía cinética media de los electrones libres en la región donde se forma las líneas de emisión del ión estudiado.

\section{Método directo}

\section{- Oxígeno}

Para el cálculo de la temperatura de [OIII] se usa el cociente de líneas $\mathrm{R}_{O 3}$. En este caso, el ajuste obtenido, al igual que para el resto de iones de tipo $\mathrm{np}^{2}$, no depende de la densidad electrónica y es, por lo tanto, un buen indicador de temperatura. El ajuste entre cociente y temperatura es:

$$
t_{e}([\mathrm{OIII}])=0,8254-0,0002415 \cdot R_{O 3}+\frac{47,77}{R_{O 3}}
$$

donde $t_{e}$ es la temperatura en unidades de $10^{4} \mathrm{~K}$

En el caso del [OII], la temperatura electrónica se calcula a partir del cociente $\mathrm{R}_{O 2}$. En este caso hay que tener algo de cuidado dado que las líneas aurorales [OII] $\lambda \lambda 7319,7330 \AA$ suelen tener algo de contaminación por emisión producida por recombinación. Dicha emisión, no obstante, se puede cuantificar y corregir. Según Liu et al. (2000) dicha contribución puede ser ajustada en el rango $0.5 \leq \mathrm{t} \leq 1.0$ mediante la función:

$$
\frac{I_{R}(7319+7330)}{I(H \beta)}=9,36 \cdot t^{0,44} \cdot \frac{O^{2+}}{H^{+}}
$$

expresión válida sólo en el rango de temperaturas entre los 5000 y los 10000 K. Además, el cociente de las líneas de [OII] depende fuertemente de la densidad electrónica. La situación ideal es tener la densidad de [OII] mediante el cociente $\mathrm{I}(3726 \AA) / \mathrm{I}(3729 \AA)$, pero generalmente no hay bastante resolución para resolver este doblete, por lo que suele ser necesario recurrir a la densidad de [SII], también representativa de la zona de baja excitación. En este trabajo, 
a pesar de poder resolver las líneas del [OII] en el espectro échelle, ambas se encuentran en el borde del orden ultravioleta del échelle con lo cual se prefirió calcular la densidad con las líneas prohibidas del azufre dos veces ionizado. El ajuste obtenido es:

$$
t_{e}([\mathrm{OII}])=0,23+0,0017 \cdot R_{O 2}+\frac{38,3}{R_{O 2}}+f_{1}\left(n_{e}\right)
$$

donde $\mathrm{f}_{1}\left(\mathrm{n}_{e}\right)$ es una función dependiente de la densidad.

- Azufre

La temperatura de [SII] se calcula con el ajuste:

$$
t_{e}([S \mathrm{II}])=1,92-0,0375 \cdot R_{S 2}^{\prime}-\frac{14,5}{R_{S 2}^{\prime}}+\frac{105,64}{R_{S 2}^{\prime 2}}+f_{2}\left(n_{e}\right)
$$

donde $\mathrm{f}_{2}\left(\mathrm{n}_{e}\right)$ es una función dependiente de la densidad.

En el caso de las líneas aurorales de [SII] basta con poder medir una de las dos, ya que entre ellas hay una relación fija teórica, de modo que $\mathrm{I}(4068 \AA) \approx 3 \cdot \mathrm{I}(4076 \AA)$. De esta manera, es posible calcular la temperatura de [SII].

En relación a la temperatura de [SIII] su medida directa se ha comenzado a utilizar cuando han empezado a ser accesibles las líneas colisionales en el infrarrojo cercano. El cociente de líneas que se usa en este caso es el $\mathrm{R}_{S 3}$. En ese caso, la temperatura de [SIII] se puede calcular mediante el ajuste:

$$
t_{e}([S \mathrm{III}])=\frac{R_{S 3}+36,4}{1,8 \cdot R_{S 3}-3,01}
$$

- Nitrógeno

La temperatura de [NII] puede ser calculada mediante el cociente de las líneas de nitrógeno, $\mathrm{R}_{N 2}$. Las líneas nebulares de [NII] están muy próximas a $\mathrm{H} \alpha$ por lo que a veces aparecen fusionadas con ésta y no es posible medirlas o medir la más débil de ellas. En ese caso se suele recurrir a la relación teórica entre ellas, de tal manera que $\mathrm{I}(6584) \approx 2.9 \cdot \mathrm{I}(6548)$. Asimismo, la emisión de la línea auroral de [NII] $\lambda 5755$ A está afectada por procesos de recombinación, que puede ser corregida mediante la siguiente expresión propuesta por Liu et al. (2000):

$$
\frac{I_{R}(5755)}{I(H \beta)}=3,19 \cdot t^{0,30} \cdot \frac{N^{2+}}{H^{+}}
$$

en el rango de temperaturas entre 5000 y 20000 K. Hägele et al. (2008) usando el cálculo de temperatura electrónica [OIII], estimaron las contribuciones por recombinación tanto en las líneas aurorales del [OII] como en la del [NII] y encontraron que en todos los casos son menores al $4 \%$. De esta forma si se opta por no corregir esta contribución, es necesario saber 
que se cuenta con un pequeño error adicional. En estas condiciones, es posible determinar la temperatura de $[\mathrm{NII}]$ mediante la expresión:

$$
t_{e}([N \mathrm{II}])=0,537+0,000253 \cdot R_{N 2}+\frac{42,126}{R_{N 2}}
$$

que no depende de la densidad electrónica debido a la naturaleza $n p^{2}$ del $\mathrm{N}^{+}$.

En ninguno de los espectros obtenidos en este trabajo, y para ninguna de las regiones observadas fue posible medir la línea auroral del [NII] en $5755 \AA$, por lo cual se tuvo que recurrir a modelos o relaciones entre temperaturas para poder derivar un valor de esta temperatura.

Las expresiones anteriores son válidas en el rango de temperaturas electrónicas entre 7000 y $23000 \mathrm{~K}$ y los errores involucrados en los ajustes son siempre menores que los errores observacionales por factores entre 5 y 10. Los errores en las temperaturas son los errores calculados a partir de las incertezas en las medidas de las intensidades de las líneas, aplicando la fórmula de propagación de errores, sin asignarle error alguno a la expresión del ajuste con el que se determina la temperatura electrónica.

\section{Relaciones entre temperaturas}

En ocasiones es posible medir sólo alguna de las líneas de emisión aurorales de los iones más representativos de la parte óptica del espectro. En esos casos, es necesario suponer una estructura interna de ionización de la región H II de estudio. Las primeras aproximaciones, consideraban a la región H II como isoterma, pero algunos estudios posteriores demostraron la existencia, en su interior, de una estructura interna de ionización que apunta a una variación espacial de la temperatura electrónica, además de la posible presencia de fluctuaciones de temperatura (Peimbert, 1967). Esto implica que, en la determinación de cada abundancia iónica, hay que tener en cuenta la temperatura media de la zona en la que el ión se encuentra. Una mejor aproximación es considerar dos zonas: una de alta ionización, la más interna y cercana al cúmulo ionizante, cuya temperatura característica sea la de [OIII], y otra de baja ionización, más externa, caracterizada por la temperatura de [OII]. Con la temperatura de la primera zona, se calculan las abundancias de iones como $\mathrm{O}^{2+}, \mathrm{S}^{2+}$ o $\mathrm{Ne}^{2+}$ y en la segunda las de $\mathrm{O}^{+}, \mathrm{S}^{+}$o $\mathrm{N}^{+}$(Pagel et al., 1992). Los trabajos de Garnett (1992) refinaron un poco esta visión al demostrar por un lado, que la temperatura de [SIII] ocupa un valor intermedio entre ambas zonas y, por otro, que las temperaturas deducidas a partir de las líneas ópticas de emisión sobreestiman el valor de la temperatura electrónica para toda la nube, ya que hay un efecto de selección hacia las zonas más calientes.

Pérez-Montero \& Díaz (2003; 2005) examinaron las relaciones entre las temperaturas que se utilizan para la determinación de la abundancia de cada ión, adaptándola a los resultados de los últimos modelos de fotoionización y la utilización de los coeficientes atómicos más recientes. Siguiendo Hägele et al., (2006; 2008), estas modificaciones han sido tenidas en 
cuenta en el presente trabajo, y fueron utilizadas en la medida que eran requeridas para derivar temperaturas. Cabe mencionar que en las relaciones entre temperaturas electrónicas no es posible obtener una estimación realista de las incertidumbres asociadas a los modelos. Los errores de los modelos no se pueden cuantificar y por ello el error que aparecerá en las tablas será una cota inferior dada por las líneas de emisión.

- $\mathrm{t}_{e}[\mathrm{OIII}]$ vs. $\mathrm{t}_{e}[\mathrm{OII}]$

En la mayoría de las regiones, las líneas aurorales de [OІІ] no son observadas con suficiente relación señal-ruido como para derivar la temperatura utilizando el método directo. Por el contrario, las líneas aurorales del [OIII] son generalmente "muy intensas" en este tipo de objetos de baja metalicidad y se las suele medir con una complicación menor pudiendo así determinar la $\mathrm{T}_{e}([\mathrm{OIII}])$ observacionalmente a través del método directo. En estos casos, se suele utilizar alguna relación basada en modelos de fotoionización para deducir $\mathrm{T}_{e}([\mathrm{OII}])$ a partir de $\mathrm{T}_{e}([\mathrm{OIII}])$. Una relación que se usa comúnmente en la bibliografía y con bastante aceptación es la expresión dada por Pagel et al., (1992):

$$
t_{e}([\mathrm{OII}])=\frac{2}{t_{e}([O \mathrm{III}])^{-1}+0,8}
$$

basada en los modelos de Stasińska (1990). Sin embargo dicha relación obvia la dependencia de $\mathrm{T}_{e}([\mathrm{OII}])$ con la densidad (Luridiana et al., 1999), hecho confirmado en parte por la gran dispersión observada al representar los objetos cuyas dos temperaturas han podido ser medidas, aunque no se ha encontrado una clara tendencia observacional con la densidad $\mathrm{N}_{e}$ (Hägele, 2008). El ajuste obtenido por Pérez-Montero \& Díaz (2003) es:

$$
t_{e}([\mathrm{OII}])=\frac{1,2+0,002 \cdot n_{e}+\frac{4,2}{n_{e}}}{t([O \mathrm{III}])^{-1}+0,08+0,003 \cdot n_{e}+\frac{2,5}{n_{e}}}
$$

y es la que se usa en este trabajo cuando la situación lo requiera, y se tenga una estimación de $\mathrm{T}_{e}[\mathrm{OIII}]$, y siempre teniendo en cuenta que en esta relación $\mathrm{T}_{e}([\mathrm{OII}])$ depende explícitamente de la densidad electrónica.

- $\mathrm{t}_{e}[\mathrm{SIII}]$ vs. $\mathrm{t}_{e}[\mathrm{OIII}]$

Existen trabajos que relacionan la temperatura de [OIII] con la temperatura de [SIII]. La motivación de dicha relación aparece con Garnett (1992) quien sugirió que la $\mathrm{T}_{e}([\mathrm{~S} I \mathrm{II}])$ ocupa un valor medio entre la de [OIII] y la de [OII], y calculó la abundancia de $\mathrm{S}^{2+}$ sólo con la línea auroral [SIII] $\lambda 6312$ Å. La relación que da Garnett es:

$$
t_{e}([S \mathrm{III}])=0,83 \cdot t_{e}([\mathrm{OIII}])+0,17
$$


En los últimos años, la importancia de esta relación ha tomado más relevancia, dado que en objetos de muy alta metalicidad se ha detectado con mayor facilidad la línea auroral de [SIII] que las líneas aurorales de otros iones y elementos. Sin embargo, la aparición de coeficientes atómicos más nuevos para las transiciones del azufre (Tayal \& Gupta, 1999) hizo que la relación subestime la $\mathrm{T}_{e}([\mathrm{~S} I I I])$. En su lugar, con los nuevos coeficientes de los modelos de fotoionización descritos en Pérez-Montero \& Díaz (2005) la relación tomó la forma:

$$
t_{e}\left(\left[S_{\mathrm{III}}\right]\right)=1,05 \cdot t_{e}([\mathrm{OIII}])-0,08
$$

Dado que la relación entre temperaturas electrónicas no permite obtener una estimación realista de las incertidumbres asociadas a los modelos y con la aparición de un cada vez mayor número de observaciones en el rango espectral donde se puede observar esta temperatura, ha sido posible obtener un nuevo ajuste empírico que tiene la forma:

$$
t_{e}([S \mathrm{III}])=(1,19 \pm 0,08) t_{e}([\mathrm{OIII}])-(0,32 \pm 0,10)
$$

definida por Hägele et al. (2006), de ahora en más H06. Este última relación empírica es la que se ha optado por aplicar en este trabajo de Tesis cuando la situación lo requiera.

- Análisis clásico: $\mathrm{t}_{e}[\mathrm{OII}]$ vs. $\mathrm{t}_{e}[\mathrm{SII}]$ vs. $\mathrm{t}_{e}[\mathrm{NII}]$

En general, es comúnmente aceptado que los tres iones, $\mathrm{O}^{+}, \mathrm{S}^{+}$y $\mathrm{N}^{+}$, se forman en la zona de baja excitación de una nebulosa y, por lo tanto, deberían tener temperaturas muy similares: $\mathrm{T}_{e}([\mathrm{OII}]) \approx \mathrm{T}_{e}([\mathrm{SII}]) \approx \mathrm{T}_{e}([\mathrm{NII}])$. Dado que es en las zonas más externas de la nebulosa donde se producen las variaciones locales más significativas de la temperatura, ha sido necesario profundizar en las relaciones entre temperaturas para mejorar las determinaciones de las abundancias de estos tres iones, teniendo siempre en consideración la dependencia de $\mathrm{T}_{e}([\mathrm{OII}])$ con la densidad.

En aquellos casos en que las líneas aurorales de [SII] no están accesibles en el espectro, se suele suponer que $\mathrm{T}_{e}([\mathrm{SII}]) \approx \mathrm{T}_{e}([\mathrm{OII}])$. Sin embargo, existen evidencias que apuntan a que esta $\mathrm{T}_{e}([\mathrm{SII}])$ es levemente menor a la $\mathrm{T}_{e}([\mathrm{OII}])$. De los modelos utilizados por Pérez-Montero \& Díaz (2003), se obtiene un ajuste lineal que resulta ser:

$$
t_{e}([S \mathrm{II}])=0,71 \cdot t_{e}([\mathrm{OII}])+0,12
$$

para una densidad electrónica de 10 partículas por $\mathrm{cm}^{3}$. Para densidades electrónicas de 100 partículas por $\mathrm{cm}^{3}$ el ajuste da:

$$
t_{e}([S \mathrm{II}])=0,86 \cdot t_{e}([\mathrm{OII}])+0,08
$$

Las observaciones confirman que en general la temperatura electrónica de [SII] es menor 
a la de [OII] para la mayor parte de las galaxias H II , sin embargo, muchas de las galaxias $\mathrm{H}$ II presentan un valor de $\mathrm{T}_{e}([\mathrm{SII}])$ menor que el predicho por los modelos. Esto podría deberse a la contribución del gas difuso ionizado por un posible escape de fotones o a una mayor contribución del [SII] en las zonas de baja excitación (Pérez-Montero \& Díaz, 2003). A pesar de estas evidencias, no existe una certeza de dicha dependencia desde el punto de vista observacional (ver Figura 2.17 de Hägele (2008). Luego, la $\mathrm{T}_{e}$ ([SII]) se ha obtenido a partir de la primera relación arriba mencionada.

Por otro lado, como se mencionó más arriba, la línea [NII] $\lambda 5755$ Å lamentablemente suele tener muy poca señal-ruido o es inobservable en nuestros espectros, por lo que es habitual considerar la aproximación $\mathrm{T}_{e}([\mathrm{NII}]) \approx \mathrm{T}_{e}([\mathrm{OII}])$ como válida. Esta relación, confirmada por los modelos, es sensible a la densidad y a la estructura de ionización interna de la nebulosa, pudiendo alcanzar valores más cercanos a $\mathrm{T}_{e}([\mathrm{SII}])$, por lo que, en todo caso, debe ser tomada con su grado de incerteza. De los modelos de fotoionización propuestos por Pérez-Montero \& Díaz (2003) resulta que la $\mathrm{T}_{e}([\mathrm{SII}])$ es sensiblemente menor que $\mathrm{T}_{e}([\mathrm{OII}])$ y que $\mathrm{T}_{e}([\mathrm{NiI}])$, lo cual puede deberse, según los autores, a la contribución de las zonas de baja excitación. Este efecto puede no ser importante en objetos de alta excitación, en que las fracciones de $\mathrm{S}^{+}$son menores, pero sí puede ser relevante a la hora de determinar la abundancia total de azufre en objetos menos excitados (ver discusión en Pérez-Montero et al., 2010).

Con las relaciones hasta aquí expuestas, se puede determinar las temperaturas faltantes debido a la no detección de alguna de las líneas aurorales correspondientes. En los casos en que ninguna línea auroral sea detectable, y con sólo la medida de las líneas más intensas, se puede recurrir al uso de los dos métodos empíricos abajo descriptos.

- Método empírico D07

El método utilizado para derivar la temperatura de [SIII] cuando no se tienen las líneas aurorales de este mismo elemento ni las de ningún otro ión o elemento, es el desarrollado por Díaz et al. (2007) basado en el parámetro empírico $\mathrm{SO}_{23}{ }^{2}$ definido por Díaz \& Pérez-Montero (2000) y recientemente reivindicado como un buen indicador de metalicidad para regiones $\mathrm{H}$ II de alta metalicidad. Dicho parámetro es la combinación de los parámetros empíricos $\mathrm{O}_{23}{ }^{3}$ (Pagel et al., 1979) y del $\mathrm{S}_{23}{ }^{4}$ (Vilchez \& Esteban, 1996) usados para la determinación de las abundancias de oxígeno, de los cuales se hablará en la Sección 4.5.4. La relación empírica entre la temperatura y el parámetro empírico esta dada por el siguiente ajuste:

$$
t_{e}([S \mathrm{III}])=0,596-0,283 \log S O_{23}+0,199\left(\log S O_{23}\right)^{2}
$$

Esta relación es válida para regiones de alta metalicidad. Pero de la Figura 9 de Díaz et al., (2007) se desprende que esta relación es válida también para el extremo de la zona donde

\footnotetext{
${ }^{2} \mathrm{SO}_{23}=\mathrm{S}_{23} / \mathrm{O}_{23}$

${ }^{3} \mathrm{O}_{23}=I(3727,29 \AA)+I(4959 \AA)+I(5007 \AA) / I(H \beta)$

${ }^{4} S_{23}=I(6717 \AA)+I(6731 \AA)+I(9069 \AA)+I(9532 \AA) / I(H \beta)$
} 
se encuentran las galaxias HiI, donde la dispersión es baja, y que es el rango de valores del parámetro empírico $\mathrm{SO}_{23}$ donde se encuentra Haro 15.

Para poder estimar así la $\mathrm{T}_{e}([\mathrm{SIII}])$, es necesaria la detección y medida de las líneas intensas del oxígeno y del azufre. Luego, haciendo uso de la relación empírica de H06 se puede estimar la temperatura del [OIII] y a partir de esta temperatura la de [OII] a través de los modelos, y posteriormente la de $[\mathrm{SII}]$ y la de $[\mathrm{NII}]$ igualándolas a $\mathrm{T}_{e}([\mathrm{OII}])$. El método para derivar las abundancias con esta temperatura y usando las líneas intensas se denomina método semi-empírico.

- Método empírico P07

En ocasiones, las líneas intensas del [SIII] no son observadas con buena calidad, o están demasiado hacia el rojo para el rango espectral obtenido. Pilyugin (2007) propuso una calibración para la relación de intensidades entre las líneas intensas y la auroral del [NII] en términos de las líneas del oxígeno, [OII] $\lambda \lambda 3727,3729 \AA$ y [OIII] $\lambda \lambda 4959,5007 \AA$, y de la línea de recombinación $H \beta$. Entonces, la temperatura electrónica del [NII], que aparentemente caracteriza a la zona de baja ionización de la nebulosa, puede ser derivada (ver Pilyugin, 2007).

$$
t_{2}=\frac{1,111}{\log Q_{N I I}-0,892-0,144 \cdot \log t_{2}+0,023 \cdot t_{2}}
$$

donde $t_{2}$ es la temperatura representativa de la zona de baja excitación y $Q_{N I I}$ es la aproximación al cociente de líneas de [NII] y sale de la relación empírica

$\log Q_{N \mathrm{II}}=2,619-0,609 \cdot \log R_{2}-0,010 \cdot\left[\log R_{2}\right]^{2}+1,085 \cdot \log (1-P)+0,382 \cdot[\log (1-P)]^{2}$

donde $\mathrm{P}$ es el parámetro de excitación que se expresa como

$$
P=R_{3} /\left(R_{3}+R_{2}\right)
$$

con $\mathrm{R}_{2}$ y $\mathrm{R}_{3}$ definidos como

$$
R_{2}=I[O \mathrm{II}] \lambda \lambda 3727,3729 / I(H \beta) \quad R_{3}=I[O \mathrm{III}] \lambda \lambda 4959,5007 /(H \beta)
$$

Siguiendo el método descripto por Pilyugin, Díaz et al., (2007) encuentran para las regiones circumnucleares de formación estelar (CNSFR) una correlación entre las temperaturas del [SIII] y del [NII], las cuales son muy similares, siendo en promedio $\mathrm{T}_{e}([\mathrm{NII}]) 500 \mathrm{~K}$ mayor que $\mathrm{T}_{e}$ ([SIII]) (ver Figura 15 de Díaz et al., 2007). Una vez estimada la temperatura del nitrógeno, es posible aproximar un valor a la temperatura del [SIII] con la aproximación $\mathrm{T}_{e}([\mathrm{NII}]) \approx 500 \mathrm{~K}$ $+\mathrm{T}_{e}([\mathrm{SIII}])$. Y así, una vez más haciendo uso de la relación empírica de H06, se puede estimar la temperatura del [OIII]. Luego, con esta temperatura y los modelos se determina $\mathrm{T}_{e}([\mathrm{OII}])$ y posteriormente la de $\mathrm{T}_{e}([\mathrm{SII}])$ suponiendo que es igual a la temperatura electrónica de [OII]. 
- $\mathrm{T}=10^{4} \mathrm{~K}$

Cuando no sólo no se pueden medir las líneas aurorales, sino que además no se cuenta con algunas de las líneas intensas para el cálculo de temperaturas electrónicas a través de los métodos empíricos que se acaban de describir, y considerando que para esta clase de objetos la temperatura suele estar alrededor de $10000 \mathrm{~K}$, se tomará este valor para la temperatura electrónica del [OIII], y con esta temperatura y los modelos se determinará $\mathrm{T}_{e}([\mathrm{OII}])$, y posteriormente $\mathrm{T}_{e}([\mathrm{SII}])$ y $\mathrm{T}_{e}([\mathrm{NII}])$, suponiendo ambas igual a la temperatura electrónica de [OII], y de $\mathrm{T}_{e}([\mathrm{SIII}])$ se determinará a través de su relación con $\mathrm{T}_{e}([\mathrm{OIII}])$ derivada por H06.

\subsubsection{Derivación de las abundancias químicas}

Para estudiar las abundancias químicas globales y discriminadas por componentes cinemáticas en cada brote de formación estelar de Haro 15, se han derivado las abundancias de las diferentes especies iónicas usando las líneas de emisión más intensas disponibles y detectadas en los espectros analizados. Para ello se utilizó la tarea ionic del paquete STSDAS de IRAF, tal como se describe en Hägele et al. (2008). Este paquete también se basa en la aproximación de un átomo de cinco niveles en equilibrio estadístico (De Robertis et al., 1987; Shaw \& Dufour, 1995). Uno de los problemas para la determinación de abundancias es no poder medir las líneas de emisión de todos los estados de ionización de los elementos cuya abundancia se quiere calcular. En general, una manera de solucionar este problema es recurrir a la cantidad llamada factor de corrección de ionización (ICF sigla en inglés de ionization correction factors) que da cuenta de la contribución a la abundancia de las especies iónicas que no han sido observadas. En este Capítulo las abundancias totales han sido obtenidas teniendo en cuenta, cuando fuese necesario, los estados de ionización inobservables de cada elemento, recurriendo a los factores de corrección de ionización ampliamente aceptados para cada especie, $\mathrm{X} / \mathrm{H}=\mathrm{ICF}\left(\mathrm{X}^{+i}\right) \mathrm{X}^{+i} / \mathrm{H}^{+}$(Pérez-Montero et al., 2007; Hägele et al., 2008).

A continuación se describen las expresiones de los ajustes usados para cada ión, una vez que se dispone de las densidades y temperaturas electrónicas derivadas adecuadamente para cada componente y medida global en cada uno de los brotes estudiados.

\section{Helio}

Las líneas de helio, al igual que las de hidrógeno son líneas de recombinación. Son bastante intensas y numerosas, aunque muchas de ellas suelen estar fusionadas con otras líneas. En general, están afectadas por la absorción de la población estelar subyacente, por fluorescencia, y tienen una contribución por excitación colisional (para un completo tratamiento de estas contribuciones ver Olive \& Skillman, 2001, 2004). Generalmente, para estimar las

abundancias de helio (una y dos veces ionizado) se usan las líneas de HeI $\lambda \lambda 4471,5876,6678$ y $7065 \AA$, y HeII $\lambda 4686 \AA$, respectivamente. En este trabajo se ha tomado la temperatura 
electrónica $\mathrm{T}_{e}([\mathrm{OIII}])$ como representativa de la zona en que estas líneas son emitidas. Usando las ecuaciones dadas por Olive \& Skillman se puede derivar el valor de $\mathrm{He}^{+} / \mathrm{H}^{+}$, usando la emisividad teórica escalada a $\mathrm{H} \beta$ de Benjamin (1999) y las expresiones para los factores de corrección colisional de Kingdon \& Ferland (1995). Para calcular la abundancia de helio dos veces ionizado, $\mathrm{He}^{2+} / \mathrm{H}^{+}$, se ha utilizado la ecuación (9) de Kunth \& Sargent (1983). Dado que los objetos observados tienen densidades electrónicas bajas, la leve dependencia con la profundidad óptica que tienen tres de las líneas medidas del He será ignorada y por eso no se ha hecho ninguna corrección por fluorescencia. Tampoco se ha hecho ninguna corrección por la posible presencia de alguna población estelar subyacente dado que las líneas de absorción de este elemento son más angostas y no se pueden ver sus alas a los lados de la emisión.

Con todo esto, es válida la aproximación para la abundancia total del helio:

$$
\frac{H e}{H}=\frac{H e^{+}+H e^{2+}}{H^{+}}
$$

Según sea el caso, los resultados obtenidos para cada línea del helio junto a sus correspondientes errores son presentados en las Tablas 4.10 y 4.11. Se adjunta el valor "adoptado" para $\mathrm{He}^{+} / \mathrm{H}^{+}$que es el promedio ponderado por los errores de las diferentes abundancias iónicas derivadas para cada línea de emisión de He I. Este valor es conocido como "adopted" (del inglés, valor considerado o adoptado). De aquí en adelante se utilizará el término valor "adoptado" teniendo en cuenta esta definición.

\section{Abundancias químicas iónicas y totales determinadas con las líneas prohibidas}

Se han calculado las abundancias iónicas y totales de O, S, N, Ne, Ar y Fe, cuando las líneas están presentes, utilizando las expresiones dadas por Hägele et al., (2008) y que son incluidas en la Tabla 4.9. Muchas veces suele ser útil expresar el cociente de algunos elementos respecto del oxígeno, por ejemplo, N/O, S/O, Ne/O, Ar/O, en unidades logarítmicas. Esto tiene la ventaja que como las abundancias iónicas se han determinado a partir de dos líneas de excitación colisional (por ejemplo, $\mathrm{N}^{+} / \mathrm{O}^{+}$), estos cocientes no dependen tanto de la temperatura electrónica. En los casos en los que no existen mediciones, ni de la línea de $[\mathrm{SII}] \lambda 4068 \AA$ ni de la línea de $[\mathrm{NII}] \lambda 5755 \AA$ (esta línea no se ha podido medir en ninguno de los brotes), y bajo la suposición de una temperatura electrónica homogénea en la zona de baja excitación, se ha considerado la aproximación $\mathrm{T}_{e}([\mathrm{NII}]) \approx \mathrm{T}_{e}([\mathrm{SII}]) \approx \mathrm{T}_{e}([\mathrm{OII}])$ explicada anteriormente en el análisis clásico.

(i) Los cocientes de abundancia iónica del oxígeno, $\mathrm{O}^{+} / \mathrm{H}^{+}$y $\mathrm{O}^{2+} / \mathrm{H}^{+}$, se pueden determinar a partir de las intensidades de las líneas [OII] $\lambda \lambda 3727,3729 \AA$ y [OIII] $\lambda \lambda 4959,5007 \AA$, respectivamente, usando para cada ión su correspondiente temperatura electrónica. Sin considerar la contribución de oxígeno neutro que, en proporción, es igual a la fracción 
Tabla 4.9: Ecuaciones para el cálculo de las abundancias de las líneas prohibidas (Hägele et al., 2008).

\begin{tabular}{ll}
\hline Ión* & Ecuación \\
\hline $\mathrm{O}^{+}$ & $\log \left(\frac{I(3727)}{I(H \beta)}\right)+5,992+\frac{1,583}{t_{e}}-0,681 \cdot \log t_{e}+\log \left(1+2,3 \cdot n_{e}\right)$ \\
$\mathrm{O}^{2+}$ & $\log \left(\frac{I(4959)+I(5007)}{I(H \beta)}\right)+6,144+\frac{1,251}{t_{e}}-0,55 \cdot \log t_{e}$ \\
$\mathrm{~S}^{+}$ & $\left.\log \left(\frac{I(6717)+I(6731)}{I(H \beta)}\right)+5,423+\frac{0,929}{t_{e}}-0,28 \cdot \log t_{e}+1,0 \cdot n_{e}\right)$ \\
$\mathrm{S}^{2+}$ & $\log \left(\frac{I(9069)+I(9532)}{I(H \beta)}\right)+5,8+\frac{0,771}{t_{e}}-0,22 \cdot \log t_{e}$ \\
$\mathrm{~N}^{+}$ & $\log \left(\frac{I(6548)+I(6584)}{I(H \beta)}\right)+6,273+\frac{0,894}{t_{e}}-0,592 \cdot \log t_{e}$ \\
$\mathrm{Ne}^{2+}$ & $\log \left(\frac{I(3868)}{I(H \beta)}\right)+6,486+\frac{1,558}{t_{e}}-0,504 \cdot \log t_{e}$ \\
$\mathrm{Ar}^{2+}$ & $\log \left(\frac{I(7137)}{I(H \beta)}\right)+6,157+\frac{0,808}{t_{e}}-0,508 \cdot \log t_{e}$ \\
$\mathrm{Ar}^{3+}$ & $\log \left(\frac{I(4740)}{I(H \beta)}\right)+5,705+\frac{1,246}{t_{e}}-0,156 \cdot \log t_{e}$ \\
$\mathrm{Fe}^{2+}$ & $\log \left(\frac{I(4658)}{I(H \beta)}\right)+3,504+\frac{1,298}{t_{e}}-0,483 \cdot \log t_{e}$ \\
\hline
\end{tabular}

* Como $12+\log \left(\mathrm{X} / \mathrm{H}^{+}\right)$

$\mathrm{t}_{e}$ es la temperatura electrónica de la línea, en unidades de $10^{4} \mathrm{~K}$

$\mathrm{n}_{e}$ es la densidad electrónica, en unidades de $10^{4} \mathrm{~cm}^{-3}$

de hidrógeno neutro, gracias a la reacción de intercambio de carga (Osterbrock, 1989):

$$
\mathrm{O}^{+}+H^{0} \rightarrow O^{0}+H^{+}
$$

Dado que a la temperatura a la que se encuentran los objetos aquí observados, la mayor parte del oxígeno se encuentra en forma de $\mathrm{O}^{+} \mathrm{y} \mathrm{O}^{2+}$, la abundancia total de oxígeno es bien representada por la expresión:

$$
\frac{O}{H}=\frac{O^{+}+O^{2+}}{H^{+}}
$$

(ii) Las abundancias iónicas del azufre, $\mathrm{S}^{+} / \mathrm{H}^{+}$y $\mathrm{S}^{2+} / \mathrm{H}^{+}$, están bien representadas por las líneas [SII] $\lambda \lambda 6717,6731 \AA$ y las líneas [SIII] $\lambda \lambda$ 9069, 9532 , respectivamente. Dependiendo del grado de excitación de la región, se podría esperar una contribución relativamente importante de $\mathrm{S}^{3+}$. Para esos estados de ionización inobservables, la abundancia total de azufre se puede calcular usando un ICF para $\mathrm{S}^{+}+\mathrm{S}^{2+}$. Una buena aproximación es la fórmula de Barker (1980), basada en los modelos de fotoionización de Stasinska (1978) y toma la forma:

$$
I C F\left(S^{+}+S^{2+}\right)=\left[1-\left(1-\frac{O^{2+}}{O^{+}+O^{2+}}\right)^{\alpha}\right]^{-1 / \alpha}
$$

con $\alpha \approx 2.5$, medida para una muestra de objetos con la línea de [SIV] a $10.5 \mu$ por Pérez-Montero et al., (2006). Utilizando este ICF como una función del cociente $\mathrm{O}^{2+} / \mathrm{O}$ 
en lugar del cociente $\mathrm{O}^{+} / \mathrm{O}$ se reduce el error propagado por esta cantidad, ya que los errores asociados a $\mathrm{O}^{2+}$ son considerablemente menores que $\mathrm{O}^{+}$(Hägele et al., 2008).

(iii) La abundancia iónica del nitrógeno, $\mathrm{N}^{+} / \mathrm{H}^{+}$, se deriva a partir de la intensidad de las líneas $[\mathrm{NII}] \lambda \lambda 6548,6584 \AA$. En caso de no disponer de alguna de ellas por su proximidad a la línea $\mathrm{H} \alpha$, se recurre a la relación teórica entre ambas líneas del [NII] antes citada. Para el cálculo de la abundancia total de nitrógeno se parte de la relación:

$$
\frac{N}{O}=\frac{N^{+}}{O^{+}}
$$

luego la abundancia total del nitrógeno, $\mathrm{N} / \mathrm{H}$, es calculada como:

$$
\log (N / H)=\log (N / O)+\log (O / H)
$$

(iv) La abundancia iónica del neón, $\mathrm{Ne}^{2+}$, se deriva usando la línea [NeIII] $\lambda 3868 \AA$. Dado que su estructura de ionización es bastante similar a la del oxígeno, clásicamente la abundancia total del neón ha sido calculada asumiendo:

$$
\frac{N e}{O}=\frac{N e^{2+}}{O^{2+}}
$$

La temperatura que se considera para este ión es la representativa de la zona de alta ionización $\mathrm{T}_{e}([\mathrm{NeIII}]) \approx \mathrm{T}_{e}([\mathrm{OIII}])$ (Peimbert \& Costero, 1969). Izotov et al. (2004) indicaron que el hacer esta suposición puede llevar a una sobreestimación de $\mathrm{Ne} / \mathrm{H}$ en

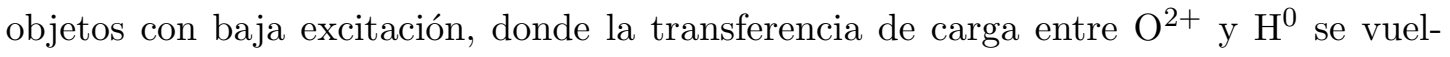
ve importante. Por este motivo aquí se calcula con el ICF dado por Pérez-Montero et al. (2007). Dada la alta excitación de los objetos observados, no hay diferencias significativas entre la abundancia total derivada para el neón usando este ICF y la estimada con el modelo clásico (Hägele et al., 2008, 2011).

(v) La abundancia iónica del argón, $\mathrm{Ar}^{2+}$, se calcula usando la línea [ArıII] $\lambda 7136$ Å asumiendo que $\mathrm{T}_{e}([\mathrm{ArIII}]) \approx \mathrm{T}_{e}([\mathrm{~S} I I])$ (Garnett, 1992). También es posible medir, en algunos espectros, las líneas del [Arıv] $\lambda 4713$ y 4740 Å. En ese caso la abundancia iónica del $\mathrm{Ar}^{3+}$, se calcula asumiendo que $\mathrm{T}_{e}([\mathrm{ArIV}]) \approx \mathrm{T}_{e}([\mathrm{OIII}])$. No obstante, la primera de las líneas del [ArIv] suele aparecer fusionada con otra línea de He I $\lambda 4711 \AA$, difícil de corregir, por lo que es mejor usar la segunda, más intensa, para calcular la abundancia de $\mathrm{Ar}^{3+}$. La abundancia total del argón es calculada usando el $\mathrm{ICF}\left(\mathrm{Ar}^{2+}\right)$ y el $\mathrm{ICF}\left(\mathrm{Ar}^{2+}+\mathrm{Ar}^{3+}\right)$ derivados a partir de modelos de fotoionización por Pérez-Montero et al. (2007).

(vi) La abundancia iónica del hierro se calcula usando la línea [FeIII] $\lambda 4658$ A y la temperatura asumida es la del [OIII]. La abundancia total es posible calcularla usando el 
ICF $\left(\mathrm{Fe}^{2+}\right)$ de Rodriguez \& Rubin (2004). En este trabajo únicamente fue posible medir la línea [FeIII] $\lambda 4658 \AA$ en el espectro de ranura larga del brote B.

Las abundancias iónicas de los elementos más pesados que el helio, los factores de corrección de ionización ICFs, las abundancias totales con sus correspondientes errores son mostrados en la Tabla 4.10 para los datos de ranura larga, y 4.11 para los datos échelle.

\subsection{Discusión}

\subsubsection{Datos de ranura larga}

Cuatro temperaturas electrónicas, $\mathrm{T}_{e}([\mathrm{OIII}]), \mathrm{T}_{e}([\mathrm{OII}]), \mathrm{T}_{e}([\mathrm{SIII}])$ y $\mathrm{T}_{e}([\mathrm{SII}])$, han sido derivadas de mediciones directas en el brote $\mathrm{B}$. La buena calidad de los datos permitió alcanzar precisiones del orden de $2 \%, 3 \%, 10 \%$ y $14 \%$, respectivamente para cada una de las temperaturas. La obtención de las cuatro temperaturas fue gracias a la buena relación $\mathrm{S} / \mathrm{N}$ del espectro que permitió la detección de las líneas débiles aurorales, como [OIII] $\lambda 4363 \AA$, [SII] $\lambda 4068 \AA$, [SIII] $\lambda 6312 \AA$ y [OHI] $\lambda \lambda 7319,7330 \AA$. Dado que la línea auroral [NiI] $\lambda 5755 \AA$ no ha sido posible medirla en el espectro, se ha considerado la aproximación $\mathrm{T}_{e}([\mathrm{NII}]) \approx \mathrm{T}_{e}([\mathrm{OII}])$ para la determinación de la temperatura $\mathrm{T}_{e}([\mathrm{NII}])$.

Se ha calculado la densidad electrónica a partir del cociente de líneas del [Sir], obteniendo un valor de 100 partículas por $\mathrm{cm}^{3}$, aunque es necesario destacar que el error de la misma es muy grande, por lo cual este valor sirve para determinar el orden de magnitud de la densidad.

Las abundancias iónicas del $\mathrm{O}^{+}, \mathrm{O}^{2+}, \mathrm{S}^{+}, \mathrm{S}^{2+}, \mathrm{N}^{+}, \mathrm{Ne}^{2+}, \mathrm{Ar}^{2+}$ y $\mathrm{Ar}^{3+}$ se han deducido utilizando las expresiones dadas en la Sección 4.4.2, las cuales dependen de la intensidad de las líneas intensas del ión cuya abundancia se quiere calcular, así como de la densidad (en algunos casos) y temperaturas electrónicas. Como en este brote fue posible medir la línea del hierro $4658 \AA$ se obtuvo también $\mathrm{Fe}^{2+}$ considerando la temperatura del [OIII] para su cálculo. Además, fueron calculadas las abundancias totales del $\mathrm{O}, \mathrm{S}, \mathrm{N}, \mathrm{Ne}, \mathrm{Ar}$ y Fe, y los cocientes logarítmicos N/O, S/O, Ne/O y Ar/O. Tanto las abundancias iónicas como las abundancias totales y los cocientes logarítmicos respecto al oxígeno, junto con sus respectivos errores, están tabulados en la Tabla 4.10 .

El brote B tiene una abundancia de oxígeno 0.22 veces el valor solar (Allende Prieto et al., 2001, $12+\log (\mathrm{O} / \mathrm{H}) \odot=8.69)$. Este valor de abundancia $(8.04 \pm 0.03)$ es similar, dentro de los

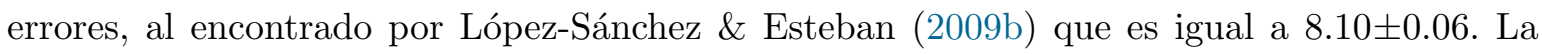
abundancia de azufre es 0.15 veces el solar (Grevesse \& Sauval, 1998, $12+\log (\mathrm{S} / \mathrm{H}) \odot=7.33$ ), y la abundancia de nitrógeno es 0.09 veces el solar (Holweger, 2001, $12+\log (\mathrm{N} / \mathrm{H}) \odot=7.93$ ). Respecto a las abundancias relativas (ver Figura 4.4), se estimó un valor de $\log (\mathrm{N} / \mathrm{O})=$ 1.16 el cual es 0.28 dex menor al valor solar (Asplund et al., 2005, $\log (\mathrm{N} / \mathrm{O}) \odot=-0.88$ ) y 
Tabla 4.10: Propiedades físicas, abundancias químicas iónicas y totales derivadas de las líneas prohibidas y de la línea de recombinación del helio para la medida global en los datos de ranura larga: brotes $\mathbf{B}$ y $\mathbf{C}$

\begin{tabular}{|c|c|c|}
\hline & $\mathrm{B}$ & $\mathrm{C}$ \\
\hline $\mathrm{n}([\mathrm{SII}])$ & 100: & 100: \\
\hline $\mathrm{T}_{e}([\mathrm{OIII}])$ & $1.26 \pm 0.03$ & $1.01 \pm 0.02^{h}$ \\
\hline $\mathrm{T}_{e}([\mathrm{SIII}])$ & $1.19 \pm 0.12$ & $0.88 \pm 0.13^{d p}$ \\
\hline $\mathrm{T}_{e}([\mathrm{OII}])$ & $1.20 \pm 0.04$ & $1.21 \pm 0.01^{m}$ \\
\hline $\mathrm{T}_{e}([\mathrm{SII}])$ & $0.79 \pm 0.11$ & $1.21 \pm 0.01^{m}$ \\
\hline $\mathrm{T}_{e}([\mathrm{NII}])$ & $1.20 \pm 0.04^{m}$ & $0.93 \pm 0.01^{p}$ \\
\hline $12+\log \left(O^{+} / H^{+}\right)$ & $7.34 \pm 0.05$ & $7.82 \pm 0.06^{m}$ \\
\hline $12+\log \left(O^{2+} / H^{+}\right)$ & $7.95 \pm 0.03$ & $7.84 \pm 0.03^{h}$ \\
\hline $12+\log (\mathrm{O} / \mathrm{H})$ & $8.04 \pm 0.03$ & $8.13 \pm 0.04^{*}$ \\
\hline $12+\log \left(S^{+} / H^{+}\right)$ & $5.95 \pm 0.20$ & $6.16 \pm 0.07^{m}$ \\
\hline $12+\log \left(S^{2+} / H^{+}\right)$ & $6.17 \pm 0.23$ & $\cdots$ \\
\hline $\operatorname{ICF}\left(S^{+}+S^{2+}\right)$ & $1.41 \pm 0.03$ & $\cdots$ \\
\hline $12+\log (\mathrm{S} / \mathrm{H})$ & $6.52 \pm 0.22$ & $\ldots$ \\
\hline $\log (\mathrm{S} / \mathrm{O})$ & $-1.52 \pm 0.22$ & $\cdots$ \\
\hline $12+\log \left(N^{+} / H^{+}\right)$ & $6.18 \pm 0.04^{m}$ & $6.70 \pm 0.07^{p}$ \\
\hline $12+\log (\mathrm{N} / \mathrm{H})$ & $6.88 \pm 0.20^{m}$ & $7.02 \pm 0.23^{p}$ \\
\hline $\log (\mathrm{N} / \mathrm{O})$ & $-1.16 \pm 0.07^{m}$ & $-1.11 \pm 0.09^{p}$ \\
\hline $12+\log \left(N e^{2+} / H^{+}\right)$ & $7.33 \pm 0.03$ & $\cdots$ \\
\hline $\mathrm{ICF}\left(N e^{2+}\right)$ & $1.08 \pm 0.01$ & $\ldots$ \\
\hline $12+\log (\mathrm{Ne} / \mathrm{H})$ & $7.36 \pm 0.03$ & $\ldots$ \\
\hline $\log (\mathrm{Ne} / \mathrm{O})$ & $-0.68 \pm 0.04$ & $\cdots$ \\
\hline $12+\log \left(A r^{2+} / H^{+}\right)$ & $5.65 \pm 0.10$ & $\cdots$ \\
\hline $12+\log \left(A r^{3+} / H^{+}\right)$ & $4.62 \pm 0.08$ & $\cdots$ \\
\hline $\operatorname{ICF}\left(A r^{2+}+A r^{3+}\right)$ & $1.03 \pm 0.01$ & $\cdots$ \\
\hline $12+\log (\mathrm{Ar} / \mathbf{H})$ & $5.70 \pm 0.10$ & $\cdots$ \\
\hline $\log (\mathrm{Ar} / \mathrm{O})$ & $-2.34 \pm 0.11$ & $\cdots$ \\
\hline $12+\log \left(F e^{2+} / H^{+}\right)$ & $5.04 \pm 0.10$ & . \\
\hline $\operatorname{ICF}\left(F e^{2+}\right)$ & $5.21 \pm 0.62$ & $\cdots$ \\
\hline $12+\log (\mathrm{Fe} / \mathrm{H})$ & $5.76 \pm 0.11$ & $\cdots$ \\
\hline$H e^{+} / H^{+}(\lambda 4471)$ & $0.064 \pm 0.003$ & . \\
\hline$H e^{+} / H^{+}(\lambda 5876)$ & $0.096 \pm 0.002$ & $\cdots$ \\
\hline $\mathrm{He}^{+} / \mathrm{H}^{+}(\lambda 6678)$ & $0.072 \pm 0.003$ & . \\
\hline$H e^{+} / H^{+}(\lambda 7065)$ & $0.100 \pm 0.008$ & $\cdots$ \\
\hline $\mathrm{He}^{+} / \mathrm{H}^{+}$adopted & $0.086 \pm 0.015$ & $\cdots$ \\
\hline$H e^{2+} / H^{+}(\lambda 4686)$ & $0.0013 \pm 0.0002$ & $\cdots$ \\
\hline$(\mathbf{H e} / \mathbf{H})$ & $0.087 \pm 0.015$ & $\ldots$ \\
\hline
\end{tabular}

${ }^{m}$ resultados usando las temperaturas predichas por los modelos, como se describe en el texto. ${ }^{d}$ resultados usando las temperaturas derivadas con el método empírico D07. ${ }^{h}$ resultados usando las temperaturas estimadas con el método empírico encontrado por Hägele et al. (2006). ${ }^{p}$ resultados usando las temperaturas derivadas con el método empírico P07. * resultados usando los datos necesarios para su cálculo que fueron derivados de modelos o relaciones empíricas. 


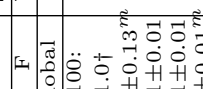

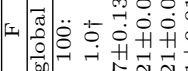

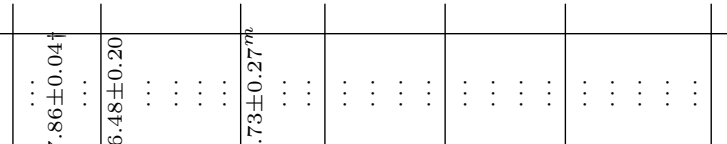

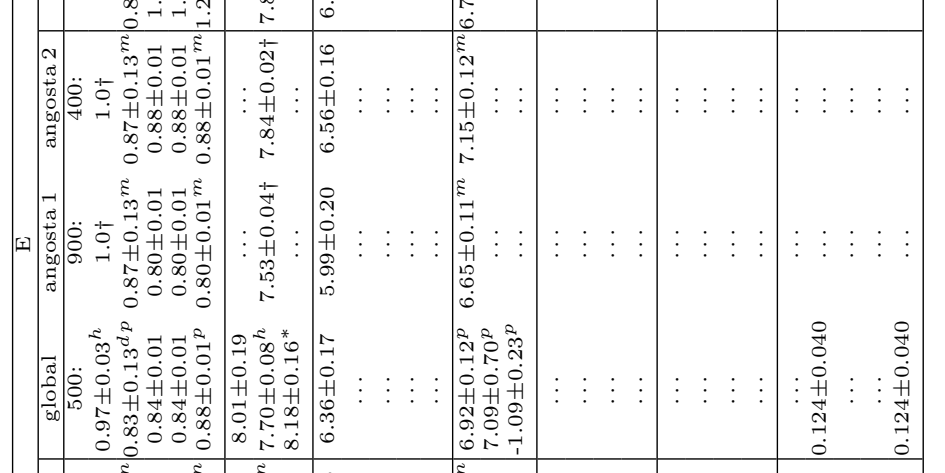

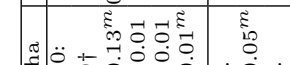
势

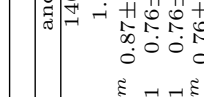

U

Ong

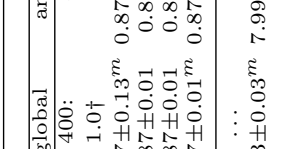

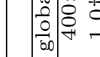

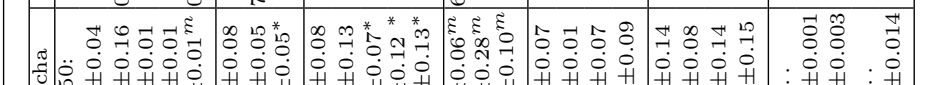

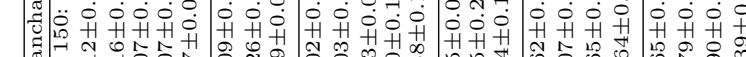

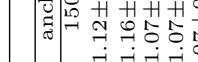

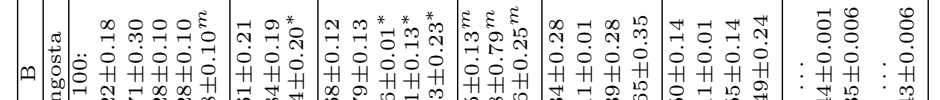

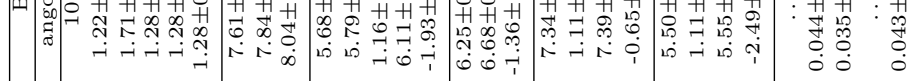

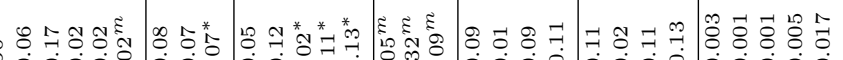

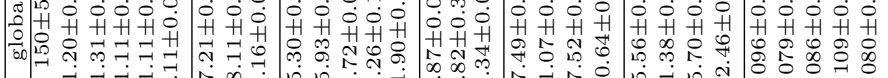

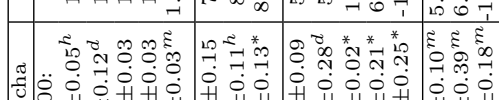

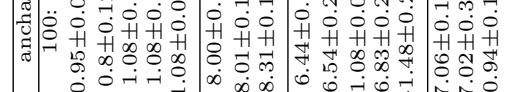

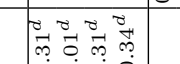

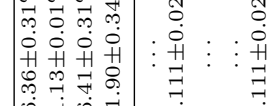

N

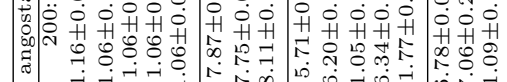

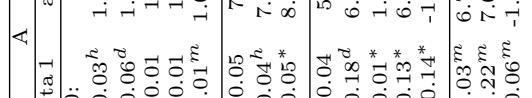

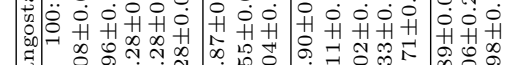

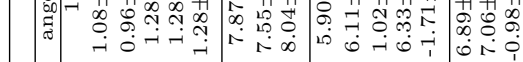

ד.

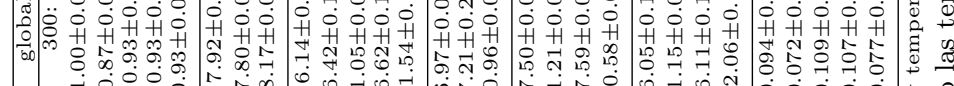

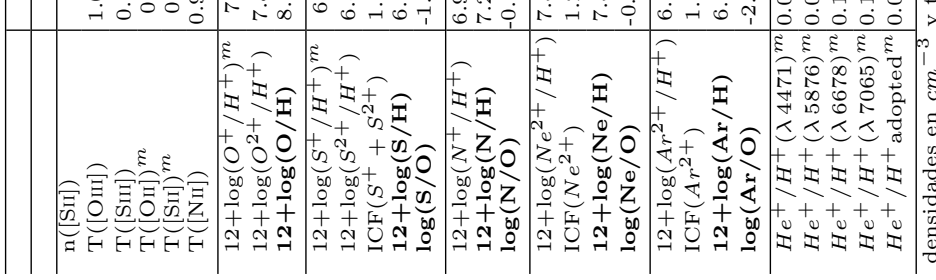


0.44 dex mayor al valor típico para este tipo de objetos (el valor del plateau se encuentra en $\log (\mathrm{N} / \mathrm{O})=-1.6$, ver Amorín et al., 2010; Pérez-Montero et al., 2011) y un valor de $\log (\mathrm{S} / \mathrm{O})=$ $-1.52 \pm 0.22$ que está de acuerdo, dentro de los errores, con el valor solar (Grevesse \& Sauval, $1998, \log (\mathrm{S} / \mathrm{O}) \odot=-1.36)$.

Ha sido posible estimar la abundancia total de He a partir de la obtención de las abundancias iónicas $\mathrm{He}^{+}$y $\mathrm{He}^{2+}$ dado que fue posible medir las líneas, HeI $\lambda \lambda 4471,5876,6678$ y $7065 \AA$, y HeII $\lambda 4686 \AA$ respectivamente. El valor "adoptado" para $\mathrm{He}^{+} / \mathrm{H}^{+}$es $0.086 \pm 0.015 \mathrm{y}$ $0.0013 \pm 0.0002$ para el $\mathrm{He}^{2+} / \mathrm{H}^{+}$dando un valor de la abundancia total del He estimada en esta región de $0.087 \pm 0.015$, valores típicos para las galaxias H II (Hägele et al., 2008). Los resultados pueden verse en la misma Tabla antes mencionada.

En el brote $\mathrm{C}$ no fue posible obtener de forma directa las temperaturas electrónicas, dado que no se pudo medir las líneas aurorales correspondientes para sus cálculos. En este caso, se recurrió tanto a los modelos como a las relaciones empíricas para determinar las diferentes temperaturas. Con el método de P07 descripto en la Sección 4.4.1, se estimó la temperatura del [NII], encontrando un valor para la misma de $0.93 \pm 0.01$. Y haciendo uso de la aproximación $\mathrm{T}_{e}([\mathrm{NII}]) \approx 500 \mathrm{~K}+\mathrm{T}_{e}([\mathrm{SIII}])$ dada por D07 se estimó un valor para la $\mathrm{T}_{e}([\mathrm{SIII}])$, con el que se derivó $\mathrm{T}_{e}([\mathrm{OIII}])$ a partir de la relación de H06. La temperatura electrónica $\mathrm{T}_{e}([\mathrm{OII}])$ fue calculada a partir de $\mathrm{T}_{e}([\mathrm{O} \mathrm{III}])$ utilizando los modelos de Pérez-Montero \& Díaz (2003) y de la aproximación $\mathrm{T}_{e}([\mathrm{SII}]) \approx \mathrm{T}_{e}([\mathrm{OII}])$ se obtuvo la temperatura de [SII]. También en este brote se estimó una densidad de 100 partículas por $\mathrm{cm}^{3}$ con errores muy grandes. Los resultados de las abundancias iónicas y totales usando las temperaturas estimadas con los modelos y los métodos empíricos, y los ICFs son expuestos en la Tabla 4.10. En este brote no se ha medido la línea [FeIII] $\lambda 4658 \AA$, por lo que no se pudo derivar una abundancia de este elemento. Tampoco, como se ha comentado en la Sección 4.3, se ha podido medir la línea [NII] $\lambda 6548 \AA$, con lo cual para el cálculo de las abundancias del nitrógeno, se ha recurrido a su relación teórica con la línea $[\mathrm{NII}] \lambda 6584$ A. Para este brote se encontró un valor de la abundancia de oxígeno de $8.13 \pm 0.04$, que es 0.28 veces el solar.

Comparando los resultados de los datos de ambos brotes en los espectros de ranura larga, se puede ver que la abundancia de oxígeno es mayor en el brote $\mathrm{C}$ que en el B pero ambas por debajo del valor solar, con valores típicos en esta clase de objetos (ver por ejemplo, Terlevich et al., 1991; Hoyos \& Díaz, 2006). Las temperaturas representativas de la zona de alta ionización son mayores en la región B. Las temperaturas correspondientes a la zona de baja ionización, en el caso de $\mathrm{T}_{e}([\mathrm{OII}])$ aparentan ser similares en ambos brotes, mientras que para $\mathrm{T}_{e}([\mathrm{SII}])$ y $\mathrm{T}_{e}([\mathrm{NII}])$ las temperaturas fueron derivadas utilizando distintas aproximaciones. En el brote B, la temperatura $\mathrm{T}_{e}([\mathrm{SII}])$, obtenida de las medidas directas y es $4200 \mathrm{~K}$ mayor que en la del brote $\mathrm{C}$, donde se derivó de suponer la igualdad con $\mathrm{T}_{e}([\mathrm{OII}])$. Es de notar que en el brote $\mathrm{B}, \mathrm{T}_{e}([\mathrm{OII}])$ es $4100 \mathrm{~K}$ más alta que $\mathrm{T}_{e}([\mathrm{SII}])$. En cuanto a la temperatura de $[\mathrm{NII}]$ en el brote B, el valor obtenido es mayor que la del brote $\mathrm{C}$ en $2700 \mathrm{~K}$, pero nuevamente fueron estimados utilizando dos aproximaciones distintas. A modo de comparación se ha derivado la 
temperatura del [NII] para el brote B usando el método P07. El valor encontrado para $\mathrm{B}$ es $\mathrm{T}_{e}([\mathrm{NII}])=10500 \pm 100 \mathrm{~K}$, que comparado con el valor de $\mathrm{T}_{e}([\mathrm{NII}])$ encontrado para el brote C usando el mismo método P07 es $\sim 1200 \mathrm{~K}$ mayor que éste. El valor estimado para N/O es un poco mayor en el brote $\mathrm{C}$ que en el $\mathrm{B}$, aunque igual dentro de los errores (ver Figura 4.4).

El grado de excitación, $\log \left(\mathrm{O}^{2+} / \mathrm{O}^{+}\right)$, calculado para el brote $\mathrm{B}$ es 0.61 y para $\mathrm{C}$ es 0.02 . Sin embargo, debe tenerse en cuenta que, para el brote $\mathrm{C}$ las abundancias iónicas se han deducido utilizando las temperaturas derivadas de los modelos y relaciones empíricas. Sin embargo, igualmente se puede considerar que es mayor el grado de excitación en el brote B que en el C, concordando este resultado con lo estimado por López-Sánchez \& Esteban (2009a). La extinción observada en ambos brotes B y C es similar dentro de los errores y consistente con baja extinción.

\subsubsection{Datos échelle}

En esta subsección se analizarán los resultados alcanzados para las regiones estudiadas con los datos de los espectros échelle. Cada brote será analizado por separado, estudiando las temperaturas, densidades, abundancias iónicas y totales estimadas para la medida global y para cada componente cinemática separadamente. Luego se dará un análisis comparativo entre brotes.

\section{Haro 15 A}

El análisis que a continuación se detalla, se refiere tanto a la medida global como a las dos componentes angostas y la componente ancha del brote A, salvo que se especifique algún análisis particular realizado sobre algunas de las componentes o medida global. Las líneas aurorales [OIII] $\lambda 4363 \AA$, [Sir] $\lambda 4068 \AA$, [SiII] $\lambda 6312 \AA$, [OII] $\lambda \lambda 7319,7330 \AA$ y [NII] $\lambda 5755 \AA$ no se han podido detectar en el espectro de la región central de Haro 15, el brote A. En este caso, utilizando la relación entre temperaturas $\mathrm{T}_{e}[\mathrm{SIII}]$ vs. $\mathrm{T}_{e}[\mathrm{OIII}]$ dada por el ajuste encontrado en H06 se ha podido estimar la temperatura electrónica del [OIII], previa determinación de $\mathrm{T}_{e}$ ([SIII]) con el método D07 usando el parámetro empírico $\mathrm{SO}_{23}$. Luego, siguiendo el análisis clásico, se han podido obtener de los modelos, las temperaturas $\mathrm{T}_{e}([\mathrm{OII}]), \mathrm{T}_{e}([\mathrm{SII}])$ y $\mathrm{T}_{e}([\mathrm{NII}])$.

Las densidades estimadas en los cuatro casos aquí analizados, están por debajo de la densidad crítica por desexcitación colisional. La medida global tiene una densidad de 300 partículas por $\mathrm{cm}^{3}$; la componente angosta 2, 200 partículas por $\mathrm{cm}^{3}$; y tanto la componente angosta 1 como la componente ancha, 100 partículas por $\mathrm{cm}^{3}$. Aún teniendo en cuenta que los valores de la densidad son una estimación de su magnitud, dado que los errores son muy grandes, parecería que la componente angosta 2 tiene una mayor densidad que las otras dos componentes. Sin embargo, y dado que la medida global es la que da una densidad mayor, no podemos afirmar nada al respecto.

En la Tabla 4.11 se muestran los resultados tanto de las propiedades físicas como de 
las abundancias iónica y totales, y los ICFs. En este brote no se ha medido la línea del [FeIII] $\lambda 4658 \AA$, pero sí se tiene una medida de las líneas del He. De la medida global, se pudo determinar un valor "adoptado" de $\mathrm{He}^{+} / \mathrm{H}^{+}$, derivado a partir de las líneas 4471, 5876, $6678,7065 \AA$, siendo el mismo de 0.077 \pm 0.023 . Para las componentes, angosta 1, angosta 2 y ancha, se encontró un valor "adoptado" de $\mathrm{He}^{+} / \mathrm{H}^{+}$usando sólo la medida de la línea $5876 \AA$, dando $0.051 \pm 0.005,0.101 \pm 0.01,0.111 \pm 0.024$ respectivamente en cada caso. El valor estimado para la componente angosta 1 es bajo, si lo comparamos con los de otras galaxias de este tipo, mientras que para las otras dos componentes los valores son típicos de galaxias H II (ver Hägele et al., 2008). Se debe destacar que el valor "adoptado" para la medida global $(0.077 \pm 0.023)$ es aproximadamente el promedio de los otros valores pesados por la luminosidad de las componentes, y está dentro de los valores típicos para esta clase de objetos.

En lo que respecta a la abundancia total del oxígeno, la medida global presenta un valor de $8.17 \pm 0.05,0.3$ veces el valor solar, mientras que para las distintas componentes cinemáticas se obtuvieron $8.04 \pm 0.05$ (angosta 1), $8.11 \pm 0.08$ (angosta 2), y 8.31 \pm 0.13 (ancha), que son 0.22, 0.26 y 0.42 veces la abundancia solar, respectivamente. Esto estaría indicando que, con errores de $1 \sigma$ (que son los dados en la tabla), la abundancia del oxígeno discriminada por componentes cinemáticas presenta valores diferentes entre la componente angosta 1 y la ancha, teniendo la componente ancha el valor más alto. La componente angosta 2 presenta el valor más próximo a la medida global, valor medio entre la ancha y la angosta 1 . Sin embargo, si se consideran los errores de $2 \sigma$ las abundancias totales de oxígeno son las mismas para todas las componentes cinemáticas. La abundancia total del oxígeno en este brote derivada para cada una de las tres componentes y en la medida global, presenta, dentro de sus errores, los característicos valores bajos que se encuentran las galaxias $\mathrm{H}$ II: $12+\log (\mathrm{O} / \mathrm{H})$ entre 7.94 y 8.19 (Terlevich et al., 1991; Hoyos \& Díaz, 2006).

La abundancia total del azufre para la medida global es 0.20 veces el valor solar, mientras que las componentes angostas 1 y 2 dan 0.10 veces el solar y la ancha 0.32 veces el valor solar. En la abundancia total del nitrógeno los valores van de 0.12 a 0.19 veces el valor solar.

Las diferentes abundancias iónicas del azufre, $\mathrm{S}^{+} / \mathrm{H}^{+}$y $\mathrm{S}^{2+} / \mathrm{H}^{+}$, la abundancia iónica $\mathrm{N}^{+} / \mathrm{H}^{+}$y la abundancia iónica $\mathrm{Ar}^{2+} / \mathrm{H}^{+}$obtenidas para la componente ancha son más altas que las encontradas en las componentes angostas, entre 0.17 a 0.61 dex respecto a la angosta 1 , y entre 0.28 a 0.73 dex respecto a la angosta 2 . Sólo se pudieron estimar las abundancias iónicas y total del [NeIII] con la medida global dado que la línea del neón en 3868 A no pudo ser resuelta por componentes cinemáticas. Los datos están expuestos en la Tabla 4.11.

Respecto a las abundancias del azufre y el nitrógeno relativas al oxígeno, los valores $\mathrm{S} / \mathrm{O}$ y N/O, la componente ancha tiene un valor del S/O próximo al de la medida global, pero si se tienen en cuenta los errores, todos los valores son muy similares entre si (ver Figura 4.4). El valor de $\mathrm{N} / \mathrm{O}$ en la componente angosta 2 es el más alto, pero su diferencia con las otras componentes está dentro de los errores como para considerarla significativa. Esto puede ser una evidencia que la evolución química de las diferentes componentes es muy similar 
(ver discusión en Pérez-Montero et al., 2011) o que directamente son distintas fases de un mismo gas. Este brote presenta un exceso muy alto de N/O (ver Figura 4.4) respecto a lo que generalmente se encuentra en las galaxias H II $(\log (\mathrm{N} / \mathrm{O})=-1.6$; Pagel et al., 1979; Alloin et al., 1979), (ver discusión en Amorín et al., 2010; Pérez-Montero et al., 2011).

La extinición observada en el brote A es consistente con baja extinción. La componente angosta 2 es las que presenta mayor extinción y la componente angosta 1 es la que muestra menor extinción. La ancha tiene una extinción con un valor promedio de las otras dos componentes cinemáticas, y la medida global muestra un valor similar, dentro de los errores, al de la componente ancha.

\section{Haro 15 B}

A diferencia del espectro obtenido en el modo de ranura larga del brote B, aquí sólo fue posible derivar dos temperaturas electrónicas con el método directo para la medida global y para las dos componentes cinemáticas angosta y ancha, $\mathrm{T}_{e}([\mathrm{OIII}])$ y $\mathrm{T}_{e}([\mathrm{SIII}])$. Las precisiones alcanzadas, respectivamente para $\mathrm{T}_{e}([\mathrm{OIII}])$ y $\mathrm{T}_{e}([\mathrm{SIII}])$ son: para la medida global, del orden de $5 \%$ y $13 \% ; 15 \%$ y $18 \%$ en la componente angosta y $4 \%$ y $14 \%$ en la ancha. La temperatura $\mathrm{T}_{e}([\mathrm{OII}])$ se obtuvo de los modelos debido a la no detección de las líneas aurorales [OII] $\lambda \lambda 7319$, $7330 \AA$. Y como no fue posible medir la línea débil auroral [SiI] $\lambda 4068 \AA$, la temperatura $\mathrm{T}_{e}([\mathrm{SII}])$ se consideró igual a $\mathrm{T}_{e}([\mathrm{OII}])$. La línea auroral $[\mathrm{NII}] \lambda 5755 \AA$ tampoco en este caso se pudo medir en el espectro, y se ha hecho la consideración $\mathrm{T}_{e}([\mathrm{NII}]) \approx \mathrm{T}_{e}([\mathrm{OII}])$.

La densidad electrónica obtenida para la medida global es de 150 partículas por $\mathrm{cm}^{3}$ con una incerteza de 50 partículas por $\mathrm{cm}^{3}$. Las densidades estimadas para las dos componentes cinemáticas están dentro del rango de bajas densidades con valores $\sim 100$ y 150 partículas por $\mathrm{cm}^{3}$ para la componente angosta y ancha, respectivamente. En estos dos últimos casos, los errores en las densidades son muy grandes, por lo cual estos valores dan una idea del orden de magnitud de la densidad.

Los resultados de las diferentes abundancias iónicas y totales junto con los ICFs derivados, y los errores correspondientes, se muestran en la Tabla 4.11. Si se comparan las abundancias iónicas derivadas para cada componente cinemática se puede ver que los iones pertenecientes a la zona de menor excitación $\left(\mathrm{O}^{+}, \mathrm{S}^{+}, \mathrm{N}^{+}\right)$muestran una mayor abundancia en la componente angosta, mientras que los iones de la zona intermendia $\left(\mathrm{S}^{2+}, \mathrm{Ar}^{2+}\right)$ y los de la zona de alta excitación $\left(\mathrm{O}^{2+}, \mathrm{Ne}^{2+}\right)$ muestran el comportamiento opuesto, siendo mayores los valores de las abundancias determinados en la componente ancha. En este espectro no se pudo medir la línea del [FeIII] en $4658 \AA$.

Los valores de las abundancias totales son: la del oxígeno derivada para la medida global es 0.3 veces el valor solar, y la componente angosta y la ancha son 0.22 y 0.4 veces el valor solar, respectivamente. Estos tres valores son típicos de las galaxias H iı. Para las abundancias de azufre los resultados son: en el caso de la medida global 0.09 veces el solar, y 0.06 y 0.12 
veces el valor solar en las respectivas componentes angosta y ancha. En el caso del nitrógeno la medida global es 0.08 veces el valor de la abundancia solar, y las componentes angosta y ancha son 0.06 y 0.11 veces el valor solar. La componente angosta parece tener un valor alto en abundancia de nitrógeno (ver valores para la muestra de galaxias H II de Pérez-Montero \& Díaz, 2003). Haciendo una consideración estadística con errores a $2 \sigma$ (los valores de los errores dados en la Tabla son a $1 \sigma$ ), los valores de las abundancias totales son iguales para las distintas componentes y para todos los elementos, dentro de esos errores, y en algunos casos incluso a $1 \sigma$. Respecto a las abundancias del azufre, nitrógeno, neón y el argón relativas al oxígeno, ambas componentes presentan, prácticamente valores iguales, incluso comparando estos valores con los estimados para la medida global. Esto podría estar indicando que ambas componentes presentan una misma evolución química y/o que son dos fases distintas de un mismo gas.

Con la medida global, ha sido posible estimar la abundancia total de He a partir de la obtención de la abundancia iónica de $\mathrm{He}^{+}$dada por la medición de las líneas HeI $\lambda \lambda 4471,5876$, 6678 y $7065 \AA$. El valor "adoptado" $\mathrm{He}^{+} / \mathrm{H}^{+}$que se ha obtenido es $0.080 \pm 0.017$, similar al encontrado en la medida del mismo brote en el espectro de ranura larga y en otras galaxias H iI (Hägele et al., 2008). En el caso de la componente angosta, el valor "adoptado" se estimó con la medida de las líneas HeI $\lambda \lambda 5876$ y $6678 \AA$ y es de $0.043 \pm 0.006$ (valor bajo para este tipo de objetos) y en la ancha $0.094 \pm 0.014$, valor típico para esta clase de galaxias. Este es el mismo comportamiento que se encontró en el brote A, entre la componente angosta 1 y las otras dos componentes.

El brote B muestra baja extinción. La componente angosta presenta mayor extinción que la componente ancha y la medida global muestra una extinción cuyo valor es el promedio de los valores de las otras dos componentes. La extinción medida en el brote B observado en el modo de dispersión simple, considerando los errores, tiene un valor levemente menor al que se observa en la componente angosta observada en el modo échelle.

\section{Haro 15 C, Haro 15 E, Haro 15 F}

A continuación en esta subsección se analizarán conjuntamente los tres brotes restantes, C, E y F, analizando las medidas globales y las diferentes componentes cinemáticas, cuando se han podido ajustar. Los espectros de estas tres regiones tienen un bajo S/N lo cual dificultó la medición de no solo las líneas débiles aurorales sino de algunas líneas más intensas necesarias para el cálculo de temperaturas y densidades.

En ninguno de los tres brotes, fue posible detectar ninguna de las líneas aurorales, además dada la baja señal de los espectros, en las medidas globales de los brotes $\mathrm{C}$ y F como en las componentes cinemáticas de los brotes $\mathrm{C}$ y E, no se pudieron medir las líneas del [OII] $\lambda \lambda 3727$, 3729 Å siendo imposible aplicar el método D07 para determinar la T $([$ SIII $])$ ni el método P07 para determinar la temperatura $\mathrm{T}_{e}([\mathrm{NII}])$, dado que estos métodos requieren de esta líneas. 
Por tal motivo, en estos casos se consideró la temperatura electrónica de [OIII] como $10^{4} \mathrm{~K}$ como fue comentado en la Sección 4.4.1. Con este valor se estimó la temperatura de [OII] usando la relación entre ambas de Pérez-Montero \& Díaz (2003), ya descripta en la misma Sección. Y las temperaturas $\mathrm{T}_{e}([\mathrm{SII}])$ y $\mathrm{T}_{e}([\mathrm{NII}])$ se consideraron iguales a la del [OII], y $\mathrm{T}_{e}([\mathrm{SIII}])$ se determinó usando su relación con la temperatura de [OIII] derivada por H06.

En cambio, en la medida global del brote E, si fue posible medir las líneas [OII] $\lambda \lambda 3727$, $3729 \AA$ A, con las cuales se pudo aplicar el método P07 para estimar la temperatura del [NII] y luego con esta temperatura estimar la $\mathrm{T}_{e}([\mathrm{SIII}])$, usando la diferencia sistemática de $500 \mathrm{~K}$ entre temperaturas hallada por Díaz et al. (2007), y $\mathrm{T}_{e}([\mathrm{OIII}])$ del ajuste de H06. La temperatura $\mathrm{T}_{e}([\mathrm{OII}])$ se obtuvo utilizando los mismos modelos y $\mathrm{T}_{e}([\mathrm{SII}])$ considerando nuevamente su igualdad con la temperatura $\mathrm{T}_{e}([\mathrm{OII}])$.

Las densidades electrónicas estimadas de la medida global como de la componente angosta del brote $\mathrm{C}$ son de 400 partículas por $\mathrm{cm}^{3}$. En el caso de la componente ancha se encontró un valor mucho más alto de 1400 partículas por $\mathrm{cm}^{3}$. Estos datos dan una estimación del orden de magnitud de la densidad electrónica, dado que la incerteza en el cálculo es muy grande. Esto en parte puede deberse a la poca señal en el espectro y a que la línea [Sir] $\lambda 6731 \AA$ debió ser corregida por emisión de líneas telúricas de cielo, dificultando los ajustes de la componente ancha (ver Tabla 4.5). La densidad estimada a partir de la medida global del brote E es de 500 partículas por $\mathrm{cm}^{3}$, mientras que la componente angosta 1 presenta una densidad electrónica de 900 partículas por $\mathrm{cm}^{3}$ y la componente angosta 2, 400 partículas por $\mathrm{cm}^{3}$. En el caso de la componente angosta 1 del brote E, el alto valor de la densidad electrónica tal vez se deba al mismo problema presentado en el brote C. En la medida global del brote F, la densidad estimada es de 100 partículas por $\mathrm{cm}^{3}$. Debido a los errores muy altos, todos estos valores dan únicamente una idea del orden en magnitud de la densidad.

Las abundancias iónicas en estas condiciones fueron difíciles de estimar. En las medidas globales de los brotes y en las dos componentes cinemáticas de los brotes $\mathrm{C}$ y E, se pudieron obtener las abundancias iónicas de $\mathrm{O}^{2+}, \mathrm{S}^{+}$y $\mathrm{N}^{+}$. En la medida global del brote E, además fue posible obtener la abundancia iónica $\mathrm{O}^{+}$y las abundancias totales del oxígeno y azufre, y se pudo estimar el cociente $\mathrm{N} / \mathrm{O}$. Todos estos datos junto a las propiedades físicas de los brotes, están expuestos en la Tabla 4.11. En estos brotes no se midió la línea [FeIII] $\lambda 4658 \AA$, por lo que no se pudo derivar una abundancia de este mismo elemento.

La abundancia de $\mathrm{O}^{2+}$ en el brote $\mathrm{C}$ derivada a partir de la componente angosta tiene un valor más alto, $\sim 0.3$ dex, que la derivada a partir de la componente ancha, pero esto podría deberse a una diferencia en el grado de ionización de las componentes. Pero, para saber si hay una diferencia real entre las abundancias se debe comparar, obviamente, las abundancias totales y no las iónicas. En la medida global, el valor de $7.83 \pm 0.03$ dex es aproximadamente el promedio de dichas abundancias iónicas derivadas para cada componente (7.85, teniendo en cuenta que la escala es logarítmica). Esto se debe a que las intensidades de las líneas de emisión corregidas por enrojecimiento son prácticamente iguales. Las abundancias iónicas del $\mathrm{S}^{+}$son 
iguales, dentro de los errores, en las dos componentes y en la medida global. Y la abundancia de $\mathrm{N}^{+}$es mayor en la angosta, 0.40 dex respecto de la ancha, pero esto nuevamente puede deberse a una diferencia en el grado de ionización de las componentes. Tanto en la abundancia del $\mathrm{O}^{2+}$ como en la de $\mathrm{N}^{+}$, la medida global es aproximadamente el valor promedio de las estimaciones para las dos componentes cinemáticas.

Las abundancias del $\mathrm{O}^{2+}, \mathrm{S}^{+}$y $\mathrm{N}^{+}$en el brote E presentan valores más altos, derivados a partir de la componente angosta 2 que para la derivada a partir de la angosta 1. Para la medida global nuevamente se ha encontrado, como era esperable, que es aproximadamente el promedio pesado por la luminosidad de las dos componentes cinemáticas. La abundancia total del oxígeno para la medida global es 0.31 veces el valor solar. En este brote se pudo estimar un valor de la abundancia de helio $(0.124 \pm 0.040)$, que es un poco elevado pero aún en el rango de las galaxias H iI (Hägele et al., 2008). El mismo fue obtenido por la medida de la línea $5876 \AA$ y fue tomado como el valor "adoptado".

La extinción observada en los brotes C y E es consistente con baja extinción. El brote C presenta valores de extinción con errores muy grandes, y solo se puede decir que las componentes cinemáticas como la medida global presentan valores de extinción similares. En el brote E, la componente angosta 1 tiene un valor de extinción mayor a los valores de extinción de la componente ancha y de la medida global, ambos, como se ha comentado más arriba, con valores de $\mathrm{c}(\mathrm{H} \beta)$ compatibles con cero dentro de los errores observacionales, y por esta razón fueron igualados a cero. En el brote F las intensidades de las líneas no fueron corregidas por enrojecimiento. .

Comparando la abundancia total de oxígeno derivada en el brote A con el valor obtenido por López-Sánchez \& Esteban (2009b), 8.37士0.10, y teniendo en cuenta los errores, se puede ver que la abundancia obtenida para la medida global es menor a este valor. Esto puede deberse a las diferentes hipótesis consideradas para determinar la temperatura electrónica y por ende las abundancias. En el brote B, el valor obtenido en la medida global se encuentra en muy buen acuerdo con el valor de abundancia total de oxígeno obtenido por López-Sánchez \& Esteban, en el mismo brote, $8.10 \pm 0.06$. Debe destacarse que para este último brote tanto el trabajo de López-Sánchez \& Esteban como el nuestro se realiza una derivación directa de la temperatura de [OIII], y que están en excelente acuerdo (12000 $\pm 600 \mathrm{~K}$ en este trabajo y $12900 \pm 700 \mathrm{~K}$ en el trabajo de López-Sánchez \& Esteban), y una estimación de $\mathrm{T}_{e}([\mathrm{OII}])$ a partir de la de [OIII], en el caso de López-Sánchez \& Esteban, utilizando la relación de Garnett (1992). Estas temperaturas también están en muy buen acuerdo, (11000 \pm 200 y $12000 \pm 500 \mathrm{~K}$, en este trabajo y en el de López-Sánchez \& Esteban, respectivamente).

Estudios recientes realizados en esta galaxia indican que el cúmulo estelar ionizante en el brote $\mathrm{B}$ sería el más jóven de la galaxia dado que este brote presenta un color azul y una alta emisión FUV, indicativo de una reciente actividad de formación estelar en curso, un resultado apoyado por la detección de rasgos Wolf-Rayet en el espectro (López-Sánchez \& Esteban, 2010). Esto está de acuerdo con los anchos equivalentes (EW) de la línea H $\beta$ (ver 
Tablas 4.2, 4.3 y 4.4) derivados de los datos de este trabajo, que reflejan que el brote B es más jóven al tener un ancho equivalente mayor al resto de los brotes (Terlevich et al., 2004). Por otro lado, del análisis realizado en este trabajo, se encuentra que la abundancia total de oxígeno derivada en los brotes A y B es muy similar.

Si se tienen en cuenta las abundancias iónicas del oxígeno derivadas para el brote B utilizando los datos de dispersión simple, puede notarse que la abundancia para el $\mathrm{O}^{+}$es menor (0.16 dex) que el valor derivado de la medida global del échelle. Ambos valores son compatibles si consideramos los errores a $2 \sigma$. Por otro lado, la abundancia de oxígeno $\mathrm{O}^{2+}$ derivada del espectro de ranura larga y de la medida global del échelle son compatibles dentro de los errores. La abundancia total de oxígeno de los datos de dispersión simple es menor (0.12 dex) si se la compara con la estimación global del échelle, y mucho menor (0.25 dex) si se la compara con la estimada en la componente ancha, pero es igual a la derivada a partir de la componente angosta. Sin embargo, si se tienen en cuenta los errores a $2 \sigma$, el valor derivado de los datos de ranura larga y el global del échelle son compatibles. También se observa que el valor "adoptado" $\mathrm{He}^{+} / \mathrm{H}^{+}$de la medida global en el brote $\mathrm{B}$ del échelle, es similar al encontrado en el espectro de ranura larga y es compatible con los valores típicos para las galaxias H II.

Se ha comentado sobre el exceso de $\mathrm{N} / \mathrm{O}$ en el brote A, el cual es muy alto respecto a los valores encontrados en las galaxias H II, aunque ya se han observado este tipo de excesos en otros objetos (ver discusión en Pérez-Montero et al., 2011). El brote B muestra también excesos en N/O pero el mismo no es tan marcado como en el caso del brote A. Los valores del S/O, para los brotes A y B, aunque presentan una gran dispersión, están en el rango de este tipo de objetos (Hägele et al., 2008) como se puede apreciar en la Figura 4.4. El brote A muestra valores mayores de este cociente, que son compatibles con el valor solar dentro de los errores, al menos para la componente ancha. El valor del $\mathrm{Ne} / \mathrm{O}$ en el brote A (medida global) y en el brote B, dentro de los errores, son consistentes con el valor solar $(\log (\mathrm{Ne} / \mathrm{O}) \odot=0.61$ dex; Grevesse \& Sauval, 1998) y se encuentran en excelente acuerdo con los valores de la literatura (Hägele et al., 2006, 2008, 2011). El valor del cociente Ar/O para el brote A presenta una dispersión mayor respecto de la que presenta el brote $\mathrm{B}$, esto se puede ver en la Figura 4.4. Los valores del Ar/O en el brote A son 0.08 y 0.39 dex mayores al valor solar $(\log (\mathrm{Ar} / \mathrm{O}) \odot=-2.29$ dex; Grevesse \& Sauval, 1998) con la excepción de la componente angosta 2 que es 0.14 dex menor al valor solar. En cambio los valores obtenidos en el brote B son entre 0.1 y 0.2 dex menores al solar. Los valores de las abundacias relativas N/O, Ne/O y $\mathrm{Ar} / \mathrm{O}$ en el brote $\mathrm{B}$ observados en ranura larga, son consistentes con los observados en el modo échelle. En cambio, el valor de S/O en el modo de dispersión simple se aparta de los valores del échelle, siendo mucho mayor.

En el caso de las abundancias totales de He, se ha encontrado un comportamiento similar para la componente angosta 1 del brote A y la angosta del brote B respecto al resto de las componentes, y es que el valor "adoptado" de $\mathrm{He}^{+} / \mathrm{H}^{+}$es bajo para este tipo de objetos, pero 
en cambio el valor obtenido para las componentes angosta 2 y ancha del brote A y para la componente ancha del brote B son valores típicos para las galaxias H II.

Respecto de los brotes C, E y F como es posible ver, el análisis comparativo sobre las abundancias iónicas y totales entre brotes es aún incompleto, dado que los espectros no han tenido la suficiente señal para realizar estas estimaciones y será necesario obtener nuevos datos para un análisis más profundo. Sólo se puede decir que la abundancia total de oxígeno del brote E para la medida global es muy similar a las abundancias obtenidas en los brotes A y B.

La extinción medida en los brotes A, B, C y E, considerando los errores, presentan valores similares y todos compatibles con baja extinción, aunque se puede decir que el brote B tiene un valor levemente menor al del resto de los brotes.

\subsubsection{Estructura de ionización}

Desde hace varios años, se vienen utilizado las líneas más intensas del espectro para deducir metalicidades a través del uso de parámetros empíricos y modelos. Encontrar una cantidad basada en la intensidad de las líneas de emisión y que se correlacione con la metalicidad no es una tarea sencilla, dado que la mayoría de las líneas de emisión dependen de la geometría de la nebulosa a través del parámetro de ionización, o la "dureza" de la radiación ionizante. La intensidad de las líneas de emisión en el oxígeno no tiene un comportamiento lineal con su abundancia debido a la importancia de dicho elemento en el proceso de enfriamiento de la nebulosa. De este modo, al aumentar la metalicidad, el enfriamiento se vuelve más eficaz, la temperatura electrónica disminuye y con ella la intensidad de las líneas. Por ello las líneas más intensas tienen un comportamiento dual, de modo tal que a metalicidad baja son directamente proporcionales a la abundancia y a metalicidades altas ocurre justo lo contrario (Osterbrock, 1989).

El parámetro de ionización, definido como el cociente entre el número de fotones ionizantes y la densidad de átomos de hidrógeno, normalizado por un factor, da una idea del grado de ionización. Físicamente se interpreta como la velocidad máxima que puede alcanzar el frente de ionización dentro de la nebulosa.

$$
U=\frac{Q(H)}{4 \pi c n_{H} r^{2}}
$$

donde $Q(H)$ es la tasa de producción de fotones de Lyman, $r$ la distancia a la estrella o cúmulo central, $n_{H}$, la densidad de átomos de hidrógeno neutros o ionizados y $c$ es la velocidad de la luz. $\mathrm{Su}$ valor efectivo es, esencialmente, lo que vale en el radio de Strömgren, $r_{S}$ :

$$
\bar{U}=\frac{Q(H)}{4 \pi c n_{H} r_{S}^{2}}=\left(Q(H) \epsilon n_{H}\right)^{1 / 3}
$$



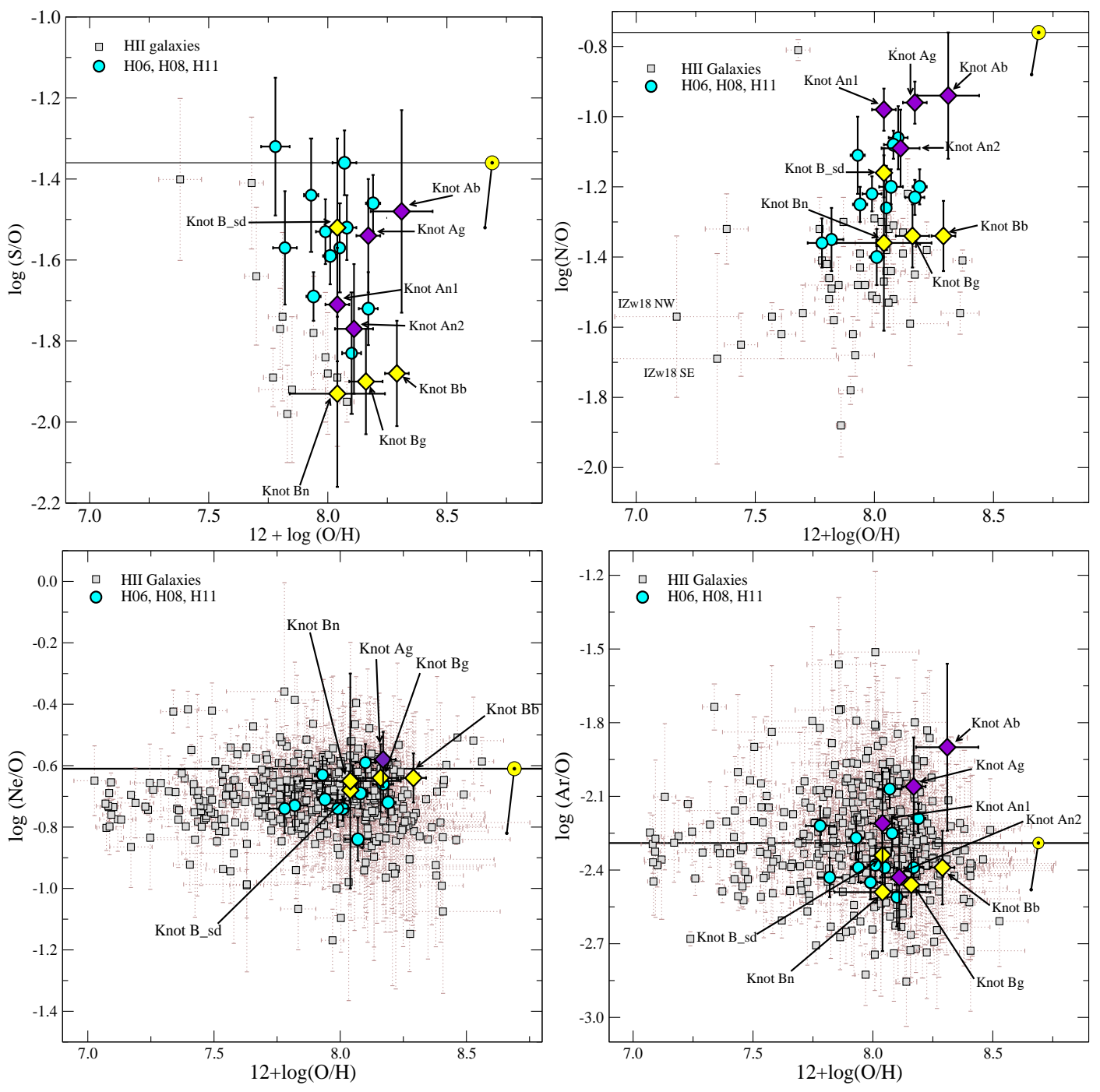

Figura 4.4: En los cuatro paneles se muestran los cocientes relativos al oxígeno: S/O, N/O, Ne/O y Ar/O en función de la abundancia de oxígeno $[12+\log (\mathrm{O} / \mathrm{H})]$. Con diamantes están representados los objetos observados: en amarillo, brote B, en violeta brote A. Los objetos observados en Hägele et al., (2006; 2008; 2011) están representados por círculos turquesa, y las galaxias Hil de la literatura recopilados por Hägele et al., (2008) para el S/O y N/O, y por PérezMontero et al., (2007) para el Ne/O y el Ar/O con cuadrados grises. Con su habitual símbolo se representa los valores de las abundancias solares: del oxígeno de Allende-Prieto et al. (2001), del nitrógeno de Holweger (2001) y Grevesse \& Sauval (1998) para el azufre, el neón y el argón. 
donde $\epsilon$ es el llamado factor de llenado que indica las irregularidades en la densidad de la nebulosa e influye en la emisividad y en la profundidad óptica. Si $\epsilon<<1$, como generalmente ocurre, la nebulosa es ópticamente delgada (Pérez-Montero, 2003).

Para la determinación del parámetro de ionización, es bastante común usar cocientes de abundancias de especies en estados consecutivos de ionización. Sin embargo, a causa de la dificultad que tiene su determinación es igual de útil, y más fácil de medir, el cociente de líneas de un mismo elemento en dos estados diferentes de ionización como es el caso de $[\mathrm{OII}] /[\mathrm{OIII}]$ o de $[\mathrm{SII}] /[\mathrm{SIII}]$. Ambos tienen un comportamiento que también depende de la temperatura efectiva del campo de radiación (Teff) de la estrella o cúmulo ionizante. El cociente $[\mathrm{OII}] /[\mathrm{OIII}]$ disminuye al aumentar Teff, al ir convirtiéndose más $\mathrm{O}^{+}$en $\mathrm{O}^{2+}$, y se considera válido en nebulosas altamente ionizadas. El cociente [SII]/[SIII], por el contrario, aumenta al aumentar Teff debido a la ionización de $\mathrm{S}^{2+}$ en $\mathrm{S}^{3+}$ y el efecto es más pronunciado cuando el grado de ionización es mayor. Por tanto, se utiliza más en nebulosas de baja ionización ( $\log \mathrm{U} \leq 2$ ). Otros indicadores del parámetro de ionización son los cocientes entre líneas colisionalmente excitadas y de recombinación, como es el caso de [SII] $\lambda 6717,6731 \AA / \mathrm{H} \alpha$ o de $[\mathrm{OII}] / \mathrm{H} \beta$ que son mucho más independientes de la temperatura efectiva y están menos afectados por enrojecimiento pero que, en cambio, dependen fuertemente de la metalicidad (Pérez-Montero, 2003).

Vílchez \& Pagel (1988) demostraron que el cociente de las cantidades $\mathrm{O}^{+} / \mathrm{O}^{2+}$ y $\mathrm{S}^{+} / \mathrm{S}^{2+}$, llamado "softness parameter" (cuyo significado en inglés es "parámetro de suavidad") y denotado con la letra griega $\eta$, está intrínsecamente relacionado con la forma del continuo ionizante y depende ligeramente de la geometría. Suponiendo una geometría esférica simple y un factor de llenado constante, el efecto geométrico puede ser representado por el parámetro de ionización que, a su vez, puede estimarse a partir del cociente [OII]/[OIII]. Y, como se vió más arriba, [OII]/[OIII] depende de Teff que, a su vez, depende de la metalicidad. El siguiente análisis sólo es posible realizarlo en los brotes con alto $\mathrm{S} / \mathrm{N}$ en sus espectros, como lo es en los brotes A y B (ver Tabla 4.12).

La contraparte puramente observacional del parámetro $\eta$ está dada por el parámetro $\eta$ ' definido también por Vílchez \& Pagel (1988) como el cociente entre las cantidades [OII]/[OIII] y [SII]/[SIII]. La relación entre ambos parámetros estará dada por el siguiente ajuste:

$$
\log \eta^{\prime}=\log \eta-0,14 t_{e}-0,16
$$

donde $\mathrm{t}_{e}$ representa la temperatura electrónica en unidades de $10^{4} \mathrm{~K}$. La relación entre $\eta$ y $\eta^{\prime}$ está dada a través de la temperatura electrónica, pero muy levemente, por lo que un cambio en la temperatura de 7000 a $14000 \mathrm{~K}$ implica un cambio en el logaritmo de un 0.1 dex, dentro de los errores de observación. Siempre el $\log \eta$ ' es inferior a $\log \eta$.

En el panel superior de la Figura 4.5 se muestra la relación entre $\log \left(\mathrm{O}^{+} / \mathrm{O}^{2+}\right)$ y $\log \left(\mathrm{S}^{+} / \mathrm{S}^{2+}\right)$ las cuales fueron derivadas usando métodos directos, modelos de fotoionización y relaciones 
Tabla 4.12: Cocientes $\log \left(\mathrm{S}^{+} / \mathrm{S}^{2+}\right)$ y $\log \left(\mathrm{O}^{+} / \mathrm{O}^{2+}\right)$ para obtener $\log \eta$, y cocientes $\log ([\mathrm{SiI}] /[\mathrm{Sir}])$ y $\log ([\mathrm{OII}] /[\mathrm{OIII}])$ para obtener $\log \eta$ ', para las distintas componentes y medidas globales de los brotes A y B. Se agrega los correspondientes valores para el brote B de dispersión simple (DS).

\begin{tabular}{ccccc}
\hline brote & $\log \left(\mathrm{S}^{+} / \mathrm{S}^{2+}\right)$ & $\log \left(\mathrm{O}^{+} / \mathrm{O}^{2+}\right)$ & $\log ([\mathrm{SII}] /[\mathrm{SIII}])$ & $\log ([\mathrm{OII}] /[\mathrm{OIII}])$ \\
\hline H15 A global & $-0.28 \pm 0.18$ & $0.12 \pm 0.07$ & $0.12 \pm 0.05$ & $0.07 \pm 0.03$ \\
angosta 1 & $-0.21 \pm 0.18$ & $0.32 \pm 0.06$ & $0.17 \pm 0.07$ & $0.26 \pm 0.03$ \\
angosta 2 & $-0.49 \pm 0.18$ & $0.12 \pm 0.12$ & $-0.17 \pm 0.08$ & $0.02 \pm 0.05$ \\
ancha & $-0.10 \pm 0.30$ & $-0.01 \pm 0.19$ & $0.37 \pm 0.14$ & $-0.01 \pm 0.09$ \\
\hline H15 B global & $-0.63 \pm 0.13$ & $-0.90 \pm 0.11$ & $-0.45 \pm 0.04$ & $-1.0 \pm 0.01$ \\
angosta & $-0.11 \pm 0.18$ & $-0.23 \pm 0.28$ & $-0.07 \pm 0.05$ & $-0.34 \pm 0.02$ \\
ancha & $-1.02 \pm 0.15$ & $-1.17 \pm 0.09$ & $-0.78 \pm 0.06$ & $-1.25 \pm 0.02$ \\
DS & $-0.23 \pm 0.30$ & $-0.60 \pm 0.06$ & $-0.30 \pm 0.05$ & $-0.78 \pm 0.01$ \\
\hline
\end{tabular}

empíricas, según corresponda el caso, para las medidas globales y las diferentes componentes cinemáticas de los brotes A y B (representados con diamantes violetas y amarillos, respectivamente). Por otra parte, en el panel inferior se representa el cociente entre el log ([OII]/[OIII]) vs. $\log ([\mathrm{SII}] /[\mathrm{SIII}])$, el cual no requiere el explícito conocimiento de la temperaturas de línea involucrada en la derivación de los cocientes iónicos, y por lo tanto no depende del método para estimar estas temperaturas. Los objetos estudiados en Hägele et al., (2006; 2008; 2011) son representados con círculos turquesas, y las galaxias Hiı, cuyos datos fueron obtenidos de la literatura con cuadrados (ver descripción y referencias en Hägele et al., 2008). Las galaxias Hiı se localizan en la región donde el $\log \eta$ está entre los valores -0.35 y 0.2 , correspondiente a valores altos de la temperatura efectiva del campo de radiacion ionizante. En la Figura 4.5 las líneas diagonales, tanto en el diagrama superior como en el inferior, representan valores constantes de $\log \eta$ y de $\log \eta$, respectivamente. En la Tabla 4.12 se muestran los valores de los cocientes $\log \left(\mathrm{O}^{+} / \mathrm{O}^{2+}\right)$ y $\log \left(\mathrm{S}^{+} / \mathrm{S}^{2+}\right)$, y $\operatorname{los}$ cocientes $\log ([\mathrm{OII}] /[\mathrm{OIII}])$ y $\log ([\mathrm{SII}] /[\mathrm{SIII}])$ para las distintas componentes y medidas globales de los brotes A y B. Tanto en la Tabla como en la Figura 4.5, y a modo de comparación, se agregaron los valores correspondientes a la medida global del brote B observado con el modo de ranura larga. Todos los objetos están señalados con sus respectivos nombres y modos de observación.

De la Figura 4.5 se desprende que el brote B tiene una estructura de ionización (o valor de $\eta$ ) muy similar comparando entre si la medida global y las distintas componentes cinemáticas, e incluso si estos valores son comparados con los valores del espectro de dispersión simple del mismo brote, y siempre considerando los errores, lo que implica que la temperatura del campo de radiación ionizante en el brote es muy parecida para las distintas componentes cinemáticas. Esto podría deberse a que el cúmulo estelar responsable de la ionización de cada componente cinemática sería el mismo. En el brote A sucede algo similar, dado que tanto las componentes cinemáticas como la medida global, presentan una estructura de ionización muy parecida y la posición en ambos diagramas es compatible, aunque los valores en el diagrama de $\eta$ 

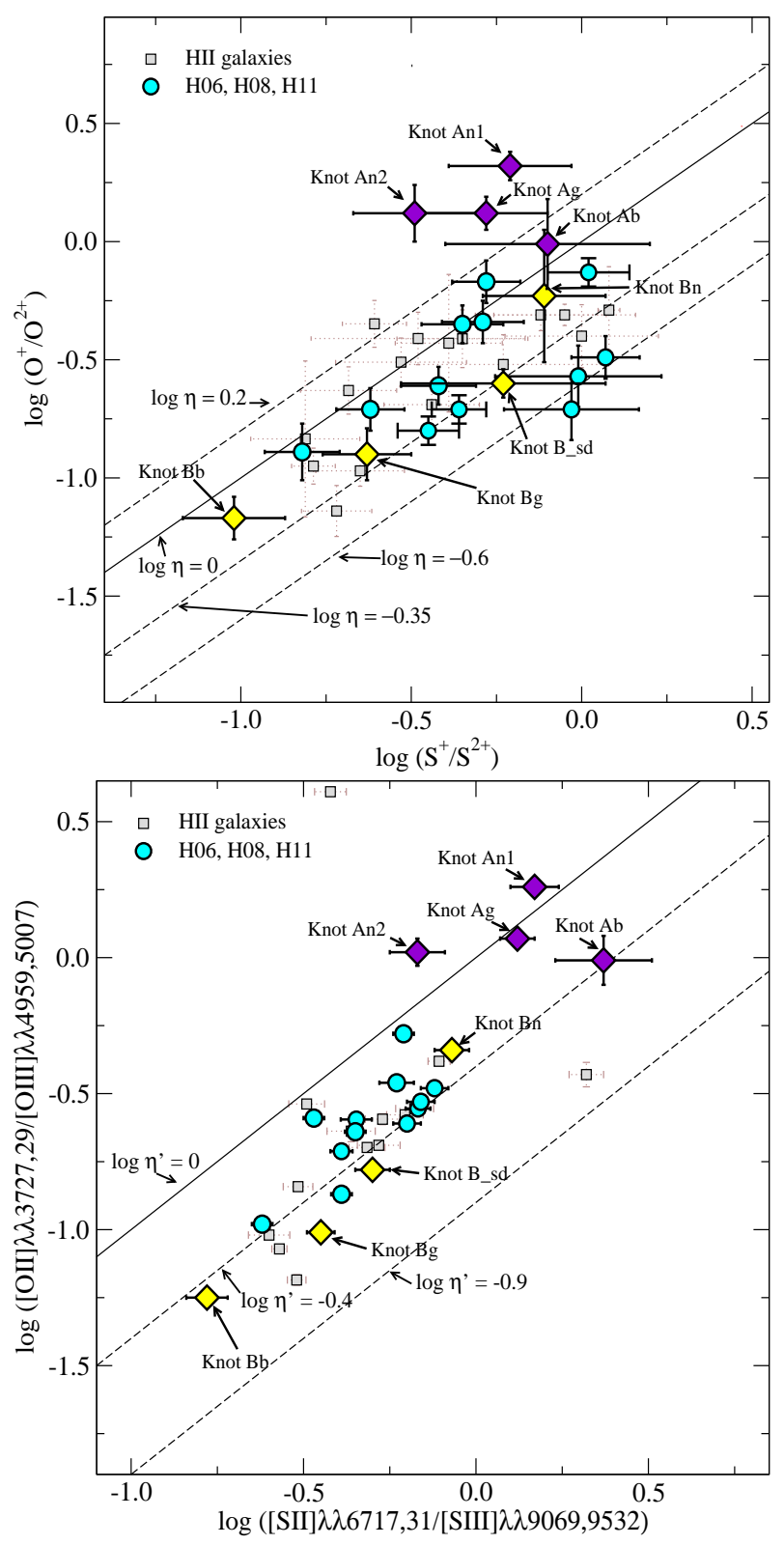

Figura 4.5: Panel superior: $\log \left(\mathrm{O}^{+} / \mathrm{O}^{2+}\right)$ vs. $\log \left(\mathrm{S}^{+} / \mathrm{S}^{2+}\right)$ para las medidas globales y las diferentes componentes cinemáticas de los brotes A y B, representados con diamantes violetas y amarillos, respectivamente. Para el brote B, se agrega el dato de dispersión simple. Las diagonales en este diagrama corresponden a valores constantes de $\log \eta$. En el Panel inferior: $\log ([\mathrm{OII}] /[\mathrm{OIII}])$ vs. $\log ([\mathrm{SII}] /[\mathrm{SiII}])$, también para las mismas medidas. Las diagonales en este otro diagrama corresponden a valores constantes de $\log \eta^{\prime}$. En ambos diagramas, los valores están representados junto a objetos estudiados por Hägele et al., (2006; 2008; 2011), representados con círculos turquesas, y a los datos de las galaxias HiI, representados con cuadrados, y cuyos valores fueron obtenidos de la literatura (ver descripción y referencias en Hägele et al., 2008). El subíndice g se refiere a la medida global, el n se refiere a la componente angosta (1 o 2, para el brote A), el subíndice b se refiere a la componente ancha, y el subíndice sd se refiere al dato de dispersión simple 
están desplazados ligeramente hacia temperaturas efectivas menores del campo de radiación ionizante. La única componente que se distancia del resto del grupo, estando en la zona de alta ionización, es la componente ancha, pero es similar si tenemos en cuenta los errores grandes en la determinación de los cocientes. Esta diferencia respecto al brote B podría deberse a un estado evolutivo diferente dado que todas las componentes del brote A se ubican hacia una región con temperaturas efectivas del campo de radiación ionizante menores respecto a las componentes del brote B, en acuerdo con la presencia de un cúmulo estelar ionizante más viejo, más evolucionado, en el brote A, como fue sugerido por López-Sánchez \& Esteban (2010). En el brote A los valores de $\eta$ y $\eta$ ' son mayores, en casi todos los casos, a los típicos valores de las galaxias H II (Hägele et al., 2008), solamente la componente ancha muestra valores de este tipo, sobre todo en el diagrama $\eta$ '. En cambio para el brote B, los valores de $\eta$ y $\eta$ ' están en el rango encontrado para las galaxias H II.

\subsubsection{Abundancias químicas usando parámetros empíricos}

Las líneas de recombinación emitidas por los metales proporcionan las abundancias más precisas gracias a su débil dependencia con la temperatura electrónica en el interior de la nebulosa. Desafortunadamente, la gran mayoría de las líneas intensas de emisión que se observan en el espectro óptico y/o que se pueden medir con suficiente precisión son de naturaleza colisional y sus intensidades dependen exponencialmente de la temperatura electrónica. En principio, esta temperatura puede ser determinada a partir de los apropiados cocientes de líneas. Sin embargo, estos cocientes necesitan de la detección y la medida de las líneas aurorales, que, como ya se ha citado anteriormente, son intrínsecamente débiles y no son detectables en algunas situaciones. Es este el mismo caso que sucede en las regiones con alto contenido metálico, donde la eficiencia del enfriamiento ejercido por los metales provoca que dichas líneas sensibles a la temperatura electrónica sean indetectables, al igual que en regiones H II en galaxias distantes y objetos con bajo brillo superficial donde no se las puede detectar debido al bajo $\mathrm{S} / \mathrm{N}$ de las mismas. En estos objetos, cuya derivación directa de las temperaturas electrónicas no es posible, son utilizados diferentes calibradores empíricos basados en las intensidades de las líneas de emisión más conspicuas.

Los métodos empíricos se basan en las propiedades de enfriamiento de las nebulosas ionizadas, esto se traduce como una relación entre las intensidades de líneas de emisión y la abundancia del oxígeno. Los métodos empíricos de derivación de abundancias dependientes de las líneas intensas que han sido ampliamente estudiados en la literatura, se basan en la calibración directa de la intensidad relativa de algunas líneas brillantes de emisión versus la abundancia de algunos iones relevantes presentes en una nebulosa (ver por ejemplo, GarcíaLorenzo et al., 2008; Cairós et al., 2009; García-Benito, 2009; García-Benito et al., 2010, y referencias en ellos).

Entre los principales estimadores empíricos utilizados en la literatura, en este apartado se 
analizan los siguientes parámetros empíricos usados cuando fue posible disponer de las líneas necesarias: $\mathrm{O}_{23}, \mathrm{~S}_{23}, \mathrm{O}_{3} \mathrm{~N}_{2}, \mathrm{~S}_{3} \mathrm{O}_{3}, \mathrm{~N}_{2}$ y $\mathrm{Ar}_{3} \mathrm{O}_{3}$. A continuación se detallan cada uno de ellos y luego se realiza una comparación entre los resultados obtenidos para los diferentes datos analizados en esta Tesis.

\section{Parámetro $\mathrm{O}_{23}$}

El parámetro O23, también conocido como $R_{23}$, propuesto por Pagel et al. (1979) se define como:

$$
O_{23}=\frac{I(3727,29 \AA)+I(4959 \AA)+I(5007 \AA)}{I(H \beta)}
$$

El mayor inconveniente que existe en utilizar el $\mathrm{O}_{23}$ es el comportamiento no lineal con la metalicidad, este parámetro tiene una naturaleza dual. El comportamiento dual de la calibración llevó a Skillman (1989) a hablar en términos de las ramas superior e inferior de la calibración y a utilizar el valor del cociente de las líneas de [OIII] $\lambda 5007 \AA /[\mathrm{NII}] \lambda 6584 \AA$ como un criterio para decidir a qué rama pertenece un objeto y usar la curva de calibración respectiva. Entonces es posible distinguir tres regiones diferentes: una rama más baja donde $\mathrm{O}_{23}$ aumenta con una abundancia cada vez mayor; una rama superior en la que ocurre lo contrario, el parámetro disminuye con una abundancia cada vez mayor y una región de cambio de orientación, que se produce en torno a $\log \mathrm{O}_{23} \approx 0.8$ y $12+\log (\mathrm{O} / \mathrm{H}) \approx 8.0$. La dependencia del $\mathrm{O}_{23}$ con el parámetro de ionización da lugar a incertidumbres para la metalicidad en aquellos objetos que se encuentran en la rama inferior, aunque la dispersión nunca es tan elevada como en la zona de cambio de orientación. Para la rama inferior tanto Skillman como McGaugh (1991) tuvieron en cuenta la dependencia de $\mathrm{O}_{23}$ con el parámetro de ionización. Pero es McGaugh quien encuentra una mejor calibración basada en los modelos teóricos en los que la ionización es proporcionada por cúmulos estelares de diferentes metalicidades, incluyendo una corrección para la variación del parámetro de ionización. En este trabajo se calculan la abundancia de oxígeno $12+\log (\mathrm{O} / \mathrm{H})$ utilizando las calibraciones de Kobulnicky et al. (1999) basadas en los modelos de McGaugh. Y se utilizó el valor del cociente entre las líneas $[\mathrm{NII}] \lambda 6584 \AA$ y $[\mathrm{OII}] \lambda 3727 \AA$ y el parámetro $\mathrm{N}_{2}$ ( = $[\mathrm{NII}] \lambda 6584 \AA / \mathrm{H} \beta$, abajo descripto), como un criterio para decidir a qué rama pertenece un objeto y así poder usar la curva de calibración respectiva (Kewley \& Ellison, 2008). Si el logaritmo del primer cociente es menor a -1.2 entonces pertenece a la rama inferior, y si el logaritmo del parámetro $\mathrm{N}_{2}$ es menor a -1.3 (entre -1.1 y -1.3 no es posible decir nada) pertenece a la rama superior. La incerteza del ajuste da, para la rama inferior un error cuadrático medio de 0.13 dex y para la rama superior 0.19 dex.

$$
\begin{gathered}
12+\log (O / H)_{\text {lower }}=12-4,944+0,767 x+0,602 x^{2}-y\left(0,29+0,332 x-0,331 x^{2}\right) \\
12+\log (O / H)_{\text {upper }}=12-2,939-0,2 x-0,237 x^{2}-0,305 x^{3}-0,0283 x^{4}-
\end{gathered}
$$




$$
y\left(0,0047-0,0221 x-0,102 x^{2}-0,0817 x^{3}-0,00717 x^{4}\right)
$$

donde

$$
\begin{gathered}
x=\log \left(O_{23}\right) \\
y=\log \left(O_{23}\right)=\log \left(\frac{[O \mathrm{III}] 4959+5007}{[O \mathrm{II}] 3727,29}\right)
\end{gathered}
$$

\section{Parámetro $\mathrm{S}_{23}$}

El parámetro $\mathrm{S}_{23}$ fue definido inicialmente por Vílchez \& Esteban (1996) como:

$$
S_{23}=\frac{I(6717 \AA)+I(6731 \AA)+I(9069 \AA)+I(9532 \AA)}{I(H \beta)}
$$

y usado por primera vez como calibrador empírico de la abundancia de azufre por Díaz \& Pérez-Montero (2000). Una de las ventajas de este parámetro es que las líneas de azufre son intensas, incluso para los objetos de mayor metalicidad. Además, el máximo de emisividad del azufre ocurre a temperaturas menores que en el caso del oxígeno, con lo cual un cambio de orientación en la curva del $\mathrm{S}_{23}$ frente a la abundancia del oxígeno se produce a metalicidad solar y no a $12+\log (\mathrm{O} / \mathrm{H})=8.0$ como se observa en el parámetro $\mathrm{O}_{23}$. Como las líneas de [SIII] cumplen con la relación teórica entre ambas de: $\mathrm{I}(9532 \AA) \approx 2.44 \cdot \mathrm{I}(9069 \AA)$, sólo se necesita disponer de una de ellas.

Para calcular la abundancia de oxígeno $(12+\log (\mathrm{O} / \mathrm{H}))$ se utilizó la calibración del parámetro empírico $\mathrm{S}_{23}$ dada por Pérez-Montero \& Díaz (2005):

$$
12+\log (O / H)=8,15+1,85 \log S_{23}+0,58\left(\log S_{23}\right)^{2}
$$

con una dispersión de 0.2 dex en todo el rango de abundancias, disminuyendo a 0.10 dex para las galaxias H II.

También es posible calcular con este parámetro, la abundancia de azufre $12+\log (\mathrm{S} / \mathrm{H})$ utilizando la calibración del parámetro empírico $\mathrm{S}_{23}$ dada por Pérez-Montero et al. (2006):

$$
12+\log (S / H)=6,622+1,860 \log S_{23}+0,382\left(\log S_{23}\right)^{2}
$$

con una incerteza de 0.19 dex, pero aquí no fue usado con este fin.

\section{Parámetro $\mathrm{SO}_{23}$}

El parámetro $\mathrm{SO}_{23}$ es la combinación entre los parámetros $\mathrm{S}_{23}$ y $\mathrm{O}_{23}$ denominado y definido por Díaz \& Pérez-Montero (2000). El mismo aumenta monótonamente con la abundancia del oxígeno hasta el régimen de abundancia sobre-solar. La calibración encontrada por Pérez- 
Montero et al. (2005) está dada por la relación:

$$
12+\log (O / H)=9,09+1,03 x-0,23 x^{2}
$$

donde

$$
x=\log \left(\frac{S_{23}}{O_{23}}\right)
$$

con una dispersión de 0.27 dex.

\section{Parámetro $\mathrm{O}_{3} \mathrm{~N}_{2}$}

El parámentro $\mathrm{O}_{3} \mathrm{~N}_{2}$ está definido por la relación:

$$
O_{3} N_{2}=\log \left(\frac{I(5007 \AA) / I(H \beta)}{I(6584 \AA) / I(H \alpha)}\right)
$$

dada por Alloin et al. (1979). Este calibrador es independiente del enrojecimiento y de la calibración en flujo. El uso del cociente $I(H \alpha) / I(H \beta)$ en la definición indica que las líneas fueron medidas respecto a la línea de recombinación más próxima para minimizar así la dependencia con el enrojecimiento o la incerteza en la calibración en flujo. El ajuste para el cálculo de la abundancia de oxígeno, $12+\log (\mathrm{O} / \mathrm{H})$, que más se usa es el de Pettini \& Pagel (2004) válida solo para $\mathrm{O}_{3} \mathrm{~N}_{2}<2$, y con un grado de incerteza de 0.25 dex.

$$
12+\log (O / H)=8,73-0,32 O_{3} N_{2}
$$

\section{Parámetro $\mathrm{S}_{3} \mathrm{O}_{3}$}

El parámetro $\mathrm{S}_{3} \mathrm{O}_{3}$ fue descripto por Stasinska (2006) y está dado por:

$$
\mathrm{S}_{3} \mathrm{O}_{3}=\frac{I(9069 \AA)}{I(5007 \AA)}
$$

Su calibración está dada por:

$$
12+\log (O / H)=8,70+0,28 x+0,03 x^{2}+0,1 x^{3}
$$

donde

$$
x=\log S_{3} O_{3}
$$

con una desviación estándar de 0.25 dex. 


\section{Parámetro $\mathrm{N}_{2}$}

El parámetro N2 se define como:

$$
N_{2}=\log \left(\frac{I(6584 \AA)}{I(H \alpha)}\right)
$$

definido por Storchi-Bergmann et al. (1994). Este estimador, en contraste al $\mathrm{O}_{23}$, tiene un carácter univaluado en relación a la metalicidad. Además, es prácticamente independiente de la correción por enrojecimiento y de la calibración en flujo de los espectros, dada la proximidad en longitud de onda de las dos líneas involucradas. Sin embargo, este parámetro tiene una alta dispersión asociada a los parámetros de la nebulosa, como por ejemplo, el parámetro de ionización y la temperatura de la radiación ionizante. También existe un alto grado de incertidumbre debido a la variación de la relación de abundancias entre nitrógeno y oxígeno, $\mathrm{N} / \mathrm{O}$, que a bajas metalicidades es constante al ser el nitrógeno de origen primario y no depender de la metalicidad. Para metalicidades mayores, en torno $12+\log (\mathrm{O} / \mathrm{H})=8.0, \mathrm{~N} / \mathrm{O}$ aumenta con la metalicidad debido a la aparición del nitrógeno secundario. La calibración más usada para calcular la abundancia de oxígeno es la de Denicoló, Terlevich \& Terlevich (2002) la cual tiene asociada una incerteza de 0.23 dex.

$$
12+\log (O / H)=(9,12 \pm 0,05)+(0,73 \pm 0,10) N_{2}
$$

\section{Parámetro $\mathrm{Ar}_{3} \mathrm{O}_{3}$}

Este parámetro también fue definido por Stasinska (2006), en busca de las mismas buenas propiedades que el calibrador $\mathrm{S}_{3} \mathrm{O}_{3}$, y se lo define como:

$$
\mathrm{Ar}_{3} \mathrm{O}_{3}=\frac{I(7136 \AA)}{I(5007 \AA)}
$$

y su calibración está dada por :

$$
12+\log (O / H)=8,91+0,34 x+0,27 x^{2}+0,20 x^{3}
$$

donde

$$
x=\log \mathrm{Ar}_{3} \mathrm{O}_{3}
$$

con una desviación estándar de 0.23 dex.

A continuación se analizarán los resultados obtenidos para la determinación de la abundancia de oxígeno con los diferentes parámetros empíricos en los diferentes objetos estudiados. Se comparan estas abundancias con las derivadas previamente usando las temperaturas estimadas. En la Figura 4.6 se puede ver las abundancias de oxígeno y sus incertezas para cada 
brote observado en Haro 15 calculadas usando los diferentes calibradores empíricos para las diferentes componentes y la medida global. De arriba a abajo: brotes A, B, C, E y F. De izquierda a derecha los diferentes parámetros empíricos: $\mathrm{S}_{23}, \mathrm{O}_{23}, \mathrm{SO}_{23}, \mathrm{O}_{3} \mathrm{~N}_{2}, \mathrm{~S}_{3} \mathrm{O}_{3}, \mathrm{~N}_{2}$ y $\mathrm{Ar}_{3} \mathrm{O}_{3}$. Con estrella azul se muestra la medida global en el échelle; con barra de error en negro los datos de dispersión simple; el triángulo turquesa hacia arriba se refiere a la componente angosta del échelle (para el brote A: el triángulo lleno representa la componente angosta 1 y el cuadrado verde lleno representa la componente angosta 2); el triángulo rosa hacia abajo es la componente ancha. Las líneas horizontales continuas representan el rango de la abundancia (teniendo en cuenta su error) derivada con la temperatura obtenida por el método directo (solo para el brote $\mathrm{B}$ en el modo de dispersión simple); la línea horizontal a trazos representa el rango de la abundancia (teniendo en cuenta su error) calculada usando la temperatura derivada de los modelos o de las relaciones empíricas entre temperaturas (los colores de estas líneas horizontales son los correspondientes a cada medida o componente, ya sea para los datos de dispersión simple (en color negro) o para las diferentes componentes (turquesa, verde o magenta) y para la medida global (azul) de los datos échelle). Por simplicidad, no se pondrá el rango de la abundancia correspondiente a la medida global en los brotes A y B ya que su valor es el promedio pesado por luminosidad de las abundancias derivadas para las distintas componentes cinemáticas. Luego, sólo se grafica este valor para el brote E dado que es la única estimación previa de su abundancia que se pudo realizar. En el caso del brote C es posible obtener y mostrar la cantidad derivada de los datos de dispersión simple, y en el caso del brote $\mathrm{F}$ es el único caso en que no se tiene una estimación previa de la abundancia total de oxígeno.

En la siguiente discusión de los resultados por brotes, siempre se tendrán en cuenta los errores.

En el brote A existe una buena concordancia entre la abundancia total de oxígeno de la medida global determinada usando los diferentes parámentro empíricos, con la respectiva abundancia derivada usando las temperaturas obtenidas de los modelos y relaciones empíricas (aunque no se muestra el valor con líneas horizontales en la Figura). La única que escapa a este resultado es la determinación de la abundancia total de oxígeno con el parámetro empírico $\mathrm{N}_{2}$, que presenta una diferencia de 0.14 dex respecto a la determinada con la temperatura obtenida con los modelos y relaciones empíricas si tenemos en cuenta la barra de error. En la componente angosta 1 existe una buena concordancia en la determinación de la abundancia usando los parámetros empíricos: $\mathrm{S}_{23}, \mathrm{O}_{23}$ y $\mathrm{SO}_{23}$, con la abundancia determinada usando las temperaturas obtenidas de los modelos y relaciones empíricas (línea horizontal discontinua turquesa). En cambio, la abundancia determinada para la misma componente angosta 1 usando los parámetros empítricos: $\mathrm{O}_{3} \mathrm{~N}_{2}, \mathrm{~S}_{3} \mathrm{O}_{3}$ y $\mathrm{N}_{2}$ y $\mathrm{Ar}_{3} \mathrm{O}_{3}$ es mayor, aunque solamente para $\mathrm{N}_{2}$ se encuentra una gran diferencia $(\sim 0.25 \mathrm{dex})$ y en los otros tres la diferencia entre las barras de error es del 
orden de 0.1 dex. La abundancia determinada para la componente angosta 2 usando los parámentros empíricos presenta buena concordancia con la abundancia derivada previamente usando las temperaturas obtenidas de los modelos y relaciones empíricas, excepto en el parámetro empírico $\mathrm{N}_{2}$, que sobreestima el valor de la abundancia de oxígeno en $\sim 0.15$ dex. La abundancia determinada para la componente ancha usando los diferentes parámetros empíricos, a excepción del $\mathrm{S}_{23}$ que es levemente mayor si se tiene en cuenta la barra de error, son muy similares a la abundancia determinada usando las temperaturas obtenidas de los modelos y relaciones empíricas (línea horizontal discontinua magenta).

En el brote B, en el dato échelle, la abundancia de oxígeno de la medida global determinada a partir de los parámetros empíricos $\mathrm{O}_{23}, \mathrm{O}_{3} \mathrm{~N}_{2}$ y $\mathrm{N}_{2}$ muestran un valor similar al derivado usando las temperaturas (aunque no se muestra este valor con líneas horizontales en la Figura). En cambio, la abundancia determinada a partir de los parámetros empíricos $\mathrm{S}_{23}, \mathrm{SO}_{23}, \mathrm{~S}_{3} \mathrm{O}_{3}$ y $\mathrm{Ar}_{3} \mathrm{O}_{3}$ presenta valores menores a la abundancia determinada usando las temperaturas, siendo el $\mathrm{S}_{23}$ y el $\mathrm{SO}_{23}$ (relacionados entre sí) los que muestran las mayores discrepancias. La componente angosta presenta valores similares en la determinación de la abundancia de oxígeno usando los diferentes parámetros empíricos y la determinada derivada usando las temperaturas (línea horizontal discontinua turquesa, que en este caso es discontinua porque $\mathrm{T}_{e}([\mathrm{OII}])$ fue determinada a través de modelos). La abundancia de oxígeno obtenida para la componente ancha y determinada a partir de los parámetros empíricos es siempre menor (excepto para el $\mathrm{O}_{23}$ que da $8.17 \pm 0.13$ ) a la determinada usando las temperaturas obtenidas (línea horizontal discontinua magenta). Esta diferencia es mucho más marcada para el parámetro $\mathrm{SO}_{23}$, de aproximadamente 0.75 dex (teniendo en cuenta las barras de error grandes, sobre todo en el parámetro empírico), aunque se observan diferencias muy grandes también para el $\mathrm{S}_{23}$ y el $\mathrm{Ar}_{3} \mathrm{O}_{3}$ (0.4 dex considerando las barras de error), y una diferencia de $\sim 0.2$ dex para los tres restantes $\left(\mathrm{O}_{3} \mathrm{~N}_{2}, \mathrm{~S}_{3} \mathrm{O}_{3}\right.$ y $\left.\mathrm{N}_{2}\right)$. En el caso del dato de dispersión simple, los valores de la abundancia total de oxígeno derivada con los parámetros empíricos están en muy buen acuerdo con la abundancia derivada usando la temperatura obtenida por el método directo (línea horizontal continua negra), excepto para los parámetros empíricos $\mathrm{S}_{23}$ y $\mathrm{SO}_{23}$ que dan valores de la abundancia de oxígeno menores, pero marginalmente coincidentes en el primer caso, y aproximadamente 0.1 dex inferior para el segundo, considerando la barra de error.

En el brote C, los valores de las abundancias determinadas para las componentes ancha y angosta, y para la medida global del échelle utilizando los parámetros empíricos $\mathrm{O}_{3} \mathrm{~N}_{2}$ y $\mathrm{N}_{2}$, están en buen acuerdo con el valor de la abundancia total del oxígeno estimada para el mismo brote con los datos de dispersión simple. Además, concuerdan con el valor de la abundancia de oxígeno determinada usando las temperaturas obtenidas de modelos 


\section{CAPÍTULO 4. ESPECTROSCOPÍA DE ALTA RESOLUCIÓN DE LA GALAXIA BCD}

y relaciones empíricas para los datos de dispersión simple (línea horizontal discontinua negra). Sólo para los datos de ranura larga, el valor de la abundancia determinada usando el parámetro empírico $\mathrm{O}_{23}$ presenta un valor ligeramente menor al derivado usando las temperaturas.

En el brote E existe una buena concordancia entre las abundancias determinadas con los parámetros empíricos $\mathrm{O}_{3} \mathrm{~N}_{2}$ y $\mathrm{N}_{2}$ para las dos componentes angostas y la medida global, y coinciden con la abundancia determinada con las temperaturas estimadas de los modelos y relaciones empíricas (línea horizontal discontinua azul), excepto para la angosta 2 con el parámetro $\mathrm{N}_{2}$. La abundancia determinada con el parámetro $\mathrm{O}_{23}$ en la medida global está un poco por debajo de los demás, pero en buen acuerdo, también con la abundancia total de oxígeno determinada a partir de las temperaturas.

En el brote F, la estimación de la abundancia para la medida global con los parámetros empíricos $\mathrm{O}_{3} \mathrm{~N}_{2}$ y $\mathrm{N}_{2}$ es similar, mostrando valores muy parecidos a los encontrados para los demás brotes de formación estelar.

Se debe tener en cuenta que las relaciones empíricas usadas aquí como para los parámetros $\eta$ y $\eta$ ' fueron derivadas a partir de medidas para regiones completas y que nunca se ha hecho un análisis y/o determinación por componentes. Este es un trabajo que merece una discusión y un tratamiento más completo que está más allá de lo que se puede realizar con los presentes datos. Es necesario realizar nuevas observaciones y ampliar la muestra de regiones con determinaciones de abundancias por componentes y también, dentro de lo posible, con una determinación directa de la abundancia iónia de $\mathrm{O}^{+}$, lo que daría una medida directa de O para las distintas componentes. 


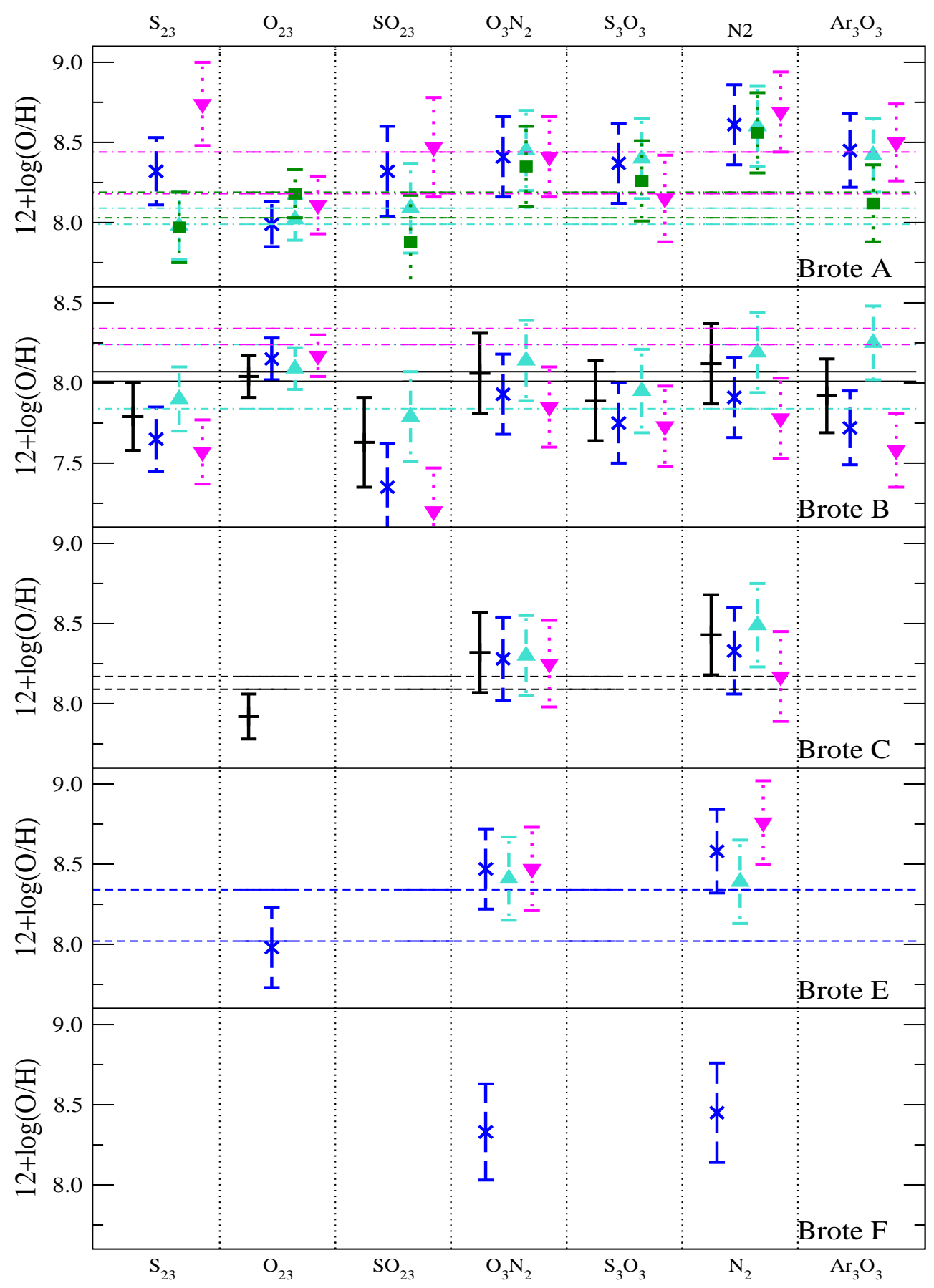

Figura 4.6: Abundancias de oxígeno y sus incertezas para cada brote observado en Haro 15 calculadas usando los diferentes parámetros empíricos para las diferentes componentes y la medida global. De arriba a abajo: brotes A, B, C, E y F. De izquierda a derecha los diferentes parámetros empíricos: $\mathrm{S}_{23}, \mathrm{O}_{23}, \mathrm{SO}_{23}, \mathrm{O}_{3} \mathrm{~N}_{2}, \mathrm{~S}_{3} \mathrm{O}_{3}, \mathrm{~N}_{2}$ y $\mathrm{Ar}_{3} \mathrm{O}_{3}$. Con estrella azul se muestra la medida global en el échelle; con barra de error en negro los datos de dispersión simple; el triángulo turquesa hacia arriba se refiere a la componente angosta del échelle (para el brote A: el triángulo lleno representa la componente angosta 1 y el cuadrado verde lleno representa la componente angosta 2); el triángulo rosa hacia abajo es la componente ancha. Las líneas horizontales representan el rango de la abundancia total de oxígeno previamente determinada (ver texto). 


\subsection{Resumen y conclusiones}

En este Capítulo se ha realizado un análisis de las características físicas del gas ionizado discriminado para cada componente y para el flujo global de las líneas de emisión del gas en los brotes más brillantes de formación estelar de la galaxia BCD Haro 15. Para esto se estimaron temperaturas y densidades electrónicas, y se obtuvieron abundancias iónicas y totales de las diferentes especies.

Como en las relaciones entre temperaturas electrónicas no fue posible obtener una estimación realista de las incertidumbres asociadas a los modelos dado que los errores de los modelos no se pueden cuantificar, los errores que se han dado en las abundancias son cotas inferiores.

De los espectros de los brotes B y C obtenidos en modo dispersión simple tomados con la cámara WFCCD del telescopio de 100" du Pont de LCO, Chile, se puede resumir los siguiente resultados:

- en el brote $\mathrm{B}$, cuatro temperaturas electrónicas, $\mathrm{T}_{e}([\mathrm{OIII}]), \mathrm{T}_{e}([\mathrm{OII}]), \mathrm{T}_{e}([\mathrm{SIII}])$ y $\mathrm{T}_{e}([\mathrm{SII}])$ fueron derivadas de mediciones directas con precisiones del orden de $2 \%, 3 \%, 10 \% \mathrm{y}$ $14 \%$ respectivamente, y se estimó la $\mathrm{T}_{e}([\mathrm{NII}])$ considerado la aproximación $\mathrm{T}_{e}([\mathrm{NII}]) \approx$ $\mathrm{T}_{e}([\mathrm{OII}])$. Mientras que en el brote $\mathrm{C}$, para determinar las temperaturas electrónicas $\mathrm{T}_{e}([\mathrm{OIII}]), \mathrm{T}_{e}([\mathrm{OII}]), \mathrm{T}_{e}([\mathrm{SIII}]), \mathrm{T}_{e}([\mathrm{SII}])$ y $\mathrm{T}_{e}([\mathrm{NII}])$ se recurrió tanto a los modelos como a las relaciones empíricas. Es de notar que en el brote $\mathrm{B}, \mathrm{T}_{e}([\mathrm{OII}])$ es $4100 \mathrm{~K}$ más alta que $\mathrm{T}_{e}([\mathrm{SII}])$. En cuanto a la temperatura de [NII] en el brote B, el valor obtenido es mayor que la del brote $\mathrm{C}$, aún estimándola usando el método P07.

- la densidad electrónica calculada a partir del cociente de líneas del [SiI] para ambos brotes está por debajo de la densidad electrónica crítica por desexcitación colisional, tal como sucede en los procesos de formación estelar en las galaxias H II.

- para el brote $\mathrm{B}$, se dedujeron las abundancias iónicas del $\mathrm{O}^{+}, \mathrm{O}^{2+}, \mathrm{S}^{+}, \mathrm{S}^{2+}, \mathrm{N}^{+}, \mathrm{Ne}^{2+}$, $\mathrm{Ar}^{2+}, \mathrm{Ar}^{3+}, \mathrm{Fe}^{2+}, \mathrm{He}^{+}$y $\mathrm{He}^{2+}$. También en este brote se calcularon las abundancias totales del O, S, N, Ne, Ar, Fe y He, y los cocientes logarítmicos N/O, S/O, Ne/O y Ar/O. En el brote $\mathrm{C}$, se estimaron las abundancias iónicas $\mathrm{O}^{+}, \mathrm{O}^{2+}, \mathrm{S}^{+}$y $\mathrm{N}^{+}$, y se calcularon las abundancias totales del $\mathrm{O}$ y $\mathrm{N}$, y la abundancia relativa $\mathrm{N} / \mathrm{O}$. El brote $\mathrm{B}$ tiene una abundancia de oxígeno $12+\log (\mathrm{O} / \mathrm{H})=8.04 \pm 0.03$ (0.22 veces el valor solar), similar, dentro de los errores, al encontrado por López-Sánchez \& Esteban (2009b) en el mismo brote. La abundancia de azufre en este brote es $6.52 \pm 0.22$ ( 0.15 veces el valor solar) y la abundancia de nitrógeno es $6.88 \pm 0.20$ (0.09 veces el valor solar). El valor estimado para $\mathrm{N} / \mathrm{O}$ es un poco mayor en el brote $\mathrm{C}$ que en el $\mathrm{B}$, aunque igual dentro de los errores, mostrando en ambos casos una sobre abundancia respecto a lo encontrado, generalmente, para las galaxias H II. 
- se ha encontrado que es mayor el grado de excitación en el brote B que en el C.

- la abundancia total del He estimada en el brote B tiene un valor típico, como los que se encuentran para las galaxias H II.

De los espectros de alta resolución tomados con el espectrógrafo échelle del telescopio de 100" du Pont de LCO, Chile, de los brotes A, B, C, E y F se puede resumir los siguiente resultados:

- en el brote A, para la medida global y para las dos componentes angostas y la componente ancha, se utilizó la relación encontrada por H06 entre temperaturas $\mathrm{T}_{e}[\mathrm{SIII}]$ vs. $\mathrm{T}_{e}[\mathrm{OIII}]$ para estimar la temperatura electrónica del [OIII], previa determinación de $\left.\mathrm{T}_{e}([\mathrm{~S} I I]]\right)$ con el método D07. Luego, siguiendo el análisis clásico, se obtuvieron de los modelos las temperaturas $\mathrm{T}_{e}([\mathrm{OII}]), \mathrm{T}_{e}([\mathrm{SII}])$ y $\mathrm{T}_{e}([\mathrm{NII}])$.

En el brote $\mathrm{B}$, se derivaron $\mathrm{T}_{e}([\mathrm{OIII}])$ y $\mathrm{T}_{e}([\mathrm{SIII}])$ con el método directo para la medida global y para las dos componentes cinemáticas, con precisiones del orden de $5 \%$ y $13 \%$ para la medida global, $15 \%$ y $18 \%$ en la componente angosta y $4 \%$ y $14 \%$ en la ancha. La temperatura $\mathrm{T}_{e}([\mathrm{OII}])$ se obtuvo de los modelos y las temperaturas $\mathrm{T}_{e}([\mathrm{SII}])$ y $\mathrm{T}_{e}([\mathrm{NII}])$ se consideraron iguales a $\mathrm{T}_{e}([\mathrm{OII}])$.

En las medidas globales de los brotes $\mathrm{C}$ y F como en las componentes cinemáticas de los brotes C y E, se consideró la temperatura electrónica de [OIII] como $10^{4} \mathrm{~K}$. Luego, con este valor se estimó la temperatura de [OII] usando la relación entre ambas de PérezMontero \& Díaz (2003), las temperaturas $\mathrm{T}_{e}([\mathrm{SII}])$ y $\mathrm{T}_{e}([\mathrm{NII}])$ se consideraron iguales a la temperatura de $[\mathrm{OII}]$, y finalmente $\mathrm{T}_{e}([\mathrm{SIII}])$ se determinó usando su relación con la temperatura de [OIII] derivada por H06. En la medida global del brote E, se pudo aplicar el método P07 para estimar la temperatura del [NII], y con esta temperatura se estimó $\mathrm{T}_{e}([\mathrm{SIII}])$ haciendo uso de la diferencia sistemática de $500 \mathrm{~K}$ entre temperaturas hallada por D07. Luego, $\mathrm{T}_{e}([\mathrm{OIII}])$ se estimó usando el ajuste de H06. La temperatura $\mathrm{T}_{e}([\mathrm{OII}])$ se obtuvo utilizando los modelos y se consideró que $\mathrm{T}_{e}([\mathrm{SII}])$ es igual a la temperatura de [OIII].

- las densidades electrónicas estimadas tanto para las medidas globales de los cinco brotes como para las diferentes componentes cinemáticas de los brotes A, B, C y E fueron calculadas a partir del cociente de líneas del [SII] y están por debajo de la densidad electrónica crítica por desexcitación colisional. Estos valores dan una estimación del orden de magnitud de la densidad, dado que la incerteza en el cálculo es muy grande, salvo en el caso del brote $\mathrm{B}$, donde la densidad electrónica obtenida para la medida global es de 150 partículas por $\mathrm{cm}^{3}$ con una incerteza de 50 partículas por $\mathrm{cm}^{3}$. 
- diferentes abundancias iónicas y totales junto con los ICFs fueron derivados tanto para las medidas globales de los cinco brotes como para las diferentes componentes cinemáticas de los brotes A, B, C y E. En el brote B, los iones pertenecientes a la zona de menor excitación $\left(\mathrm{O}^{+}, \mathrm{S}^{+}, \mathrm{N}^{+}\right)$muestran una mayor abundancia en la componente angosta, mientras que los iones de la zona intermendia $\left(\mathrm{S}^{2+}, \mathrm{Ar}^{2+}\right)$ y los de la zona de alta excitación $\left(\mathrm{O}^{2+}, \mathrm{Ne}^{2+}\right)$ muestran el comportamiento opuesto.

Las abundancias totales de $\mathrm{O}, \mathrm{S}, \mathrm{N}, \mathrm{Ne}$ y Ar, donde fue posible obtenerlas, se encuentran en el mismo rango de las abundancias totales medidas para las galaxias H II. La abundancia total de oxígeno derivada en el brote B está en muy buen acuerdo con el valor obtenido por López-Sánchez \& Esteban (2009b), pero en el brote A las abundancias aquí derivadas son menores $(\sim 0.2 \mathrm{dex})$ al valor encontrado por López-Sánchez \& Esteban, aunque si se tienen en cuenta las barras de error la diferencia se reduce a $\sim 0.05$ dex. Del análisis realizado se encuentra que, dentro de los errores, la abundancia total de oxígeno derivada en los brotes A, B y la medida global del brote E son muy similares.

Si se comparan los valores derivados en el brote B para los datos échelle con los estimados a partir de los datos de ranura larga se puede apreciar que la abundancia total de oxígeno es menor para los datos de dispersión simple comparándola con la estimación global (aunque muy parecido se considera los errores), y más aún si se la compara con la componente ancha, pero es igual al derivado para la angosta.

Se encontró un exceso de $\mathrm{N} / \mathrm{O}$ en el brote A y B, siendo en A muy alto respecto a los valores encontrados en las galaxias H II, aunque este tipo de excesos ya fue observado en otros casos (ver discusión en Pérez-Montero et al., 2011). Los valores del S/O, para los brotes A y B, aunque presentan una gran dispersión, están en el rango en el que suelen encontrarse este tipo de objetos. Y los valores del Ne/O en el brote A (medida global) y en el brote $\mathrm{B}$, dentro de los errores, son consistentes con los valores de la literatura. Finalmente, el valor del cociente Ar/O para el brote A presenta una dispersión mayor respecto de la que presenta el brote $\mathrm{B}$, y en ambos casos dentro de los valores típicos para esta clase de objetos. La similitud, dentro de los errores, en las abundancias relativas $\mathrm{S} / \mathrm{O}$ y N/O en las tres componentes del brote A podría ser una evidencia que la evolución química de las diferentes componentes es muy similar o que directamente son distintas fases de un mismo gas. Una situación similar ocurre con las abundancias relativas S/O, $\mathrm{N} / \mathrm{O}, \mathrm{Ne} / \mathrm{O}$ y $\mathrm{Ar} / \mathrm{O}$ de las dos componentes del brote B. Los valores de las abundacias relativas $\mathrm{N} / \mathrm{O}, \mathrm{Ne} / \mathrm{O}$ y $\mathrm{Ar} / \mathrm{O}$ en el brote $\mathrm{B}$ observados en ranura larga, son consistentes con los observados en el modo échelle, salvo el valor $\mathrm{S} / \mathrm{O}$ que es mayor en dispersión simple que en échelle.

- se encontró que las abundancias totales de He tienen un comportamiento similar para la componente angosta 1 del brote A y la angosta del brote B respecto al resto de las 
componentes, y es que el valor "adoptado" de $\mathrm{He}^{+} / \mathrm{H}^{+}$es bajo para este tipo de objetos, pero en cambio el valor obtenido para las componentes angosta 2 y ancha del brote A, y para la componente ancha del brote B son valores típicos de los encontrados para galaxias H II. Sin embargo, se necesitan datos mejores para estudiar este comportamiento y tratar de reducir los errores de estas estimaciones.

- la extinción medida en los brotes A, B, C y E, considerando los errores, presentan valores similares y todos compatibles con baja extinción, aunque se puede decir que el brote B tiene un valor levemente menor al del resto de los brotes.

- será necesario obtener nuevos datos de los brotes C, E y F para un análisis más profundo de las abundancias iónicas y totales.

- analizando el brote A y el brote B por separado, y considerando los errores, las diferentes componentes cinemáticas de cada brote presentan una estructura de ionización similar entre ellas, lo cual implicaría que la temperatura del campo de radiación ionizante dentro de cada brote es muy parecida para las distintas componentes cinemáticas. Esto podría deberse a que el cúmulo estelar responsable de la ionización de cada una de las componentes sería el mismo. Para el brote B, este resultado es válido tanto para los datos échelle como para los datos de dispersión simple.

- las abundancias totales de oxígeno estimadas con los diferentes parámetros empíricos, en general, muestran valores consistentes con las abundancias derivadas usando las temperaturas electrónicas obtenidas ya sea de los modelos y relaciones empíricas o por métodos directos, excepto en determinados casos donde los valores de las abundancias determinadas con algunos parámetros dan valores que sobreestiman o subestiman la abundancia total de oxígeno obtenida previamente.

Cabe destacar que las relaciones empíricas usadas aquí como las usadas para los parámetros $\eta$ y $\eta$ ' fueron derivadas a partir de medidas para regiones completas y que nunca se ha hecho un análisis y/o determinación por componentes. Este es un trabajo que merece una discusión y un tratamiento más completo que está más allá de lo que se puede realizar con los presentes datos. 



\section{Conclusiones y Trabajo a futuro}

En esta tesis he identificado y analizado las características físicas y cinemática de una muestra de Regiones Hir Gigantes en galaxias observables con telescopios del Hemisferio Sur. También he definido la naturaleza y las propiedades físicas de las componentes gaseosas en algunos brotes de formación estelar masiva de la galaxia BCD Haro 15, permitiendo analizar las abundancias químicas iónicas y totales de las mismas. Para llevar a cabo este trabajo se han utilizado técnicas de espectroscopía de alta resolución como lo es la espectroscopía échelle, y también he utilizado, para una galaxia, espectros de dispersión simple de baja resolución.

Analizando 11 regiones His luminosas en galaxias espirales y en una galaxia BCD, he obtenido los siguientes resultados generales importantes:

$\boldsymbol{V}$ he encontrado comportamientos cinemáticos complejos en seis regiones de formación estelar de las galaxias espirales NGC 6070, NGC 7479 y en cinco brotes de formación estelar violenta en la galaxia compacta azul Haro 15. En cuatro de ellas se hallaron indicios de la presencia de componentes con velocidades radiales distintas, prácticamente imposibles de detectar espacialmente.

$\boldsymbol{V}$ he realizado un estudio detallado de las propiedades físicas de los principales brotes de formación estelar de la galaxia BCD Haro 15 utilizando espectroscopía de ranura larga y échelle obtenida en LCO.

Dentro de esos resultados puedo decir que:

- Fue posible determinar la dispersión de velocidades dada por el ensanchamiento del perfil de líneas de emisión nebular para cada región. La alta relación $\mathrm{S} / \mathrm{N}$, junto a la resolución del espectro échelle permitió resolver el perfil de las líneas de emisión y calcular la dispersión de velocidades del gas ionizado. Este análisis fue hecho midiendo el ancho observado del perfil de las líneas de recombinación de hidrógeno después de corregir el mismo por el perfil instrumental y por la contribución térmica. Fue posible confirmar la naturaleza gigante de las regiones candidatas. 
- De la muestra de seis GHiIR en las galaxias NGC 6070 y NGC 7479, se ha encontrado que todas ellas muestran evidencia de un residuo presente en los perfiles de las líneas de emisión. En estas regiones se ha intentado ajustar una componente ancha o dos componentes simétricas separadas en velocidad respecto a la componente principal. Todas las regiones estudiadas presentan componentes cinemáticas supersónicas.

- Los cinco brotes de la galaxia Haro 15, a excepción del brote F, muestran múltiples componentes supersónicas. En el brote F el ensanchamiento del perfil integrado solamente pudo ser detectado en la línea $\mathrm{H} \alpha$. En esta línea de emisión se pudo ajustar una componente ancha supersónica de $22 \mathrm{kms}^{-1}$ y una angosta subsónica de $8 \mathrm{~km} \mathrm{~s}^{-1}$, dispersión de velocidades típica de regiones H II clásicas, aunque la presencia de una componente ancha sea casi exclusiva de las Regiones H in Gigantes.

- Si bien las características de estas Regiones Hir Gigantes presentan una correlación en el plano $\log (L)-\log (\sigma)$, la presencia de múltiples componentes cinemáticas influye fuertemente en la ubicación final en dicho plano. Esto representa un alerta importante ante el uso indiscriminado de dicha regresión cuando no se tienen datos completos sobre el comportamiento dinámico de los brotes de formación estelar. Las componentes angostas identificadas en los perfiles complejos siguen la relación de sistemas virializados, en cambio los perfiles ajustados con una componente Gaussiana simple muestran una pendiente más plana.

- El análisis de las observaciones realizadas por Hägele y colaboradores (2006; 2008; 2011) y la metodología definida por ellos para obtener abundancias elementales precisas de $\mathrm{O}$, $\mathrm{S}, \mathrm{N}, \mathrm{Ne}, \mathrm{Ar}$ y Fe en el gas ionizado, me ha permitido estimar en los brotes de la galaxia Haro 15 por lo menos cuatro temperaturas de línea: $\mathrm{T}_{e}([\mathrm{OIII}]), \mathrm{T}_{e}([\mathrm{SIII}]), \mathrm{T}_{e}([\mathrm{OII}])$ y $\mathrm{T}_{e}([\mathrm{SII}])$, y una densidad electrónica, $\mathrm{N}_{e}([\mathrm{SII}])$ para los datos de ranura larga. Para los datos échelle, cada brote fue analizado por separado, estudiando las temperaturas, densidades, abundancias iónicas y totales estimadas para la medida global y para cada componente cinemática separadamente. En el brote B fue el único brote para el que se derivaron $\mathrm{T}_{e}([\mathrm{OIII}])$ y $\mathrm{T}_{e}([\mathrm{SIII}])$ con el método directo para la medida global y para las dos componentes cinemáticas, con precisiones del orden de $5 \%$ y $13 \%$ para la medida global, $15 \%$ y $18 \%$ en la componente angosta y $4 \%$ y $14 \%$ en la ancha. En el resto de los brotes (A, C, E y F) las temperaturas electrónicas fueron estimadas usando, según el caso, los modelos, relaciones entre temperaturas, métodos empíricos o incluso en algunos casos cuando no fue posible derivar ninguna temperatura, se consideró la temperatura electrónica de [OIII] como $10^{4} \mathrm{~K}$ y de ella, usando relaciones entre temperaturas, se obtuvo el resto. Las densidades electrónicas $\mathrm{N}_{e}([\mathrm{SII}])$ fueron calculadas a partir del cociente de líneas del [SII] y todas están por debajo de la densidad electrónica crítica por desexcitación colisional. 
- Con estas medidas y un tratamiento cuidadoso y realista de los errores observacionales, se obtuvieron estimaciones de las abundancias químicas iónicas y totales del $\mathrm{O}, \mathrm{S}, \mathrm{N}, \mathrm{Ne}$, Ar, Fe y He, según fuere el caso. Este análisis detallado de las abundancias fue realizado en cada brote de formación estelar con más de una componente y en cada una de las componentes individuales, ya sea en los datos de dispersión simple como en los datos espectroscópicos échelle. Las abundancias totales de O, S, N, Ne y Ar, donde fue posible obtenerlas, se encuentran en el mismo rango de las abundancias totales medidas para las galaxias H II. La abundancia total de oxígeno derivada en el brote B está en muy buen acuerdo con el valor obtenido por López-Sánchez \& Esteban (2009b), pero en el brote A las abundancias aquí derivadas son menores $(\sim 0.2 \mathrm{dex})$ al valor encontrado por López-Sánchez \& Esteban, aunque si se tienen en cuenta las barras de error la diferencia se reduce a $\sim 0.05$ dex. Del análisis realizado se encuentra que, dentro de los errores, la abundancia total de oxígeno derivada en lo brotes A, B y la medida global del brote E son muy similares. Como en las relaciones entre temperaturas electrónicas no fue posible obtener una estimación realista de las incertidumbres asociadas a los modelos dado que los errores de los modelos no se pueden cuantificar, los errores que se han dado en las abundancias son cotas inferiores.

- Se encontró un exceso de N/O en el brote A y B, siendo en A muy alto respecto a los valores encontrados en las galaxias H II, aunque este tipo de excesos ya fue observado en otros casos (ver discusión en Pérez-Montero et al., 2011). Los valores del S/O, para los brotes A y B, aunque presentan una gran dispersión, están en el rango en el que suelen encontrarse este tipo de objetos. Y los valores del Ne/O en el brote A (medida global) y en el brote B, dentro de los errores, son consistentes con los valores de la literatura. Finalmente, el valor del cociente Ar/O para el brote A presenta una dispersión mayor respecto que la del brote $\mathrm{B}$, y en ambos casos el valor del cociente está dentro de los valores típicos para esta clase de objetos. La similitud, dentro de los errores, en las abundancias relativas $\mathrm{S} / \mathrm{O}$ y N/O en las tres componentes del brote A podría ser una evidencia que la evolución química de las diferentes componentes es muy similar o que directamente son distintas fases de un mismo gas. Una situación similar ocurre con las abundancias relativas $\mathrm{S} / \mathrm{O}, \mathrm{N} / \mathrm{O}, \mathrm{Ne} / \mathrm{O}$ y Ar/O de las dos componentes del brote B. Los valores de las abundacias relativas $\mathrm{N} / \mathrm{O}, \mathrm{Ne} / \mathrm{O}$ y $\mathrm{Ar} / \mathrm{O}$ en el brote $\mathrm{B}$ observados en los datos espectroscópicos obtenidos con ranura larga, son consistentes con los observados en el modo échelle, salvo el valor $\mathrm{S} / \mathrm{O}$ que es mayor en dispersión simple que en modo échelle.

- Se encontró que las abundancias totales de He tienen un comportamiento similar para la componente angosta 1 del brote A y la angosta del brote B respecto al resto de las componentes. El valor "adoptado" de $\mathrm{He}^{+} / \mathrm{H}^{+}$que se obtuvo es bajo para este tipo de objetos. En cambio, el valor obtenido para las componentes angosta 2 y ancha del 
brote A, y para la componente ancha del brote B son valores típicos a los encontrados para las galaxias H II. Es necesario obtener nuevos y mejores datos para estudiar este comportamiento, además de tratar de reducir los errores de las estimaciones de las abundancias iónicas y totales de helio.

- La extinción medida en los brotes A, B, C y E, considerando los errores, presentan valores similares y todos compatibles con baja extinción, aunque se puede decir que el brote $\mathrm{B}$ tiene un valor levemente menor al del resto de los brotes.

- En los brotes A y B de Haro 15, la estructura de ionización y, por ende la temperatura del campo de radiación ionizante, es muy similar para cada componente del respectivo brote estudiado. Esto implicaría que el cúmulo ionizante de cada una de las componentes del brote en cuestión sería el mismo. La excepción estaría en la componente ancha del brote A que difiere levemente de su grupo pero es similar si consideramos los errores. El brote $\mathrm{B}$ tiene una ionización más alta que el brote $\mathrm{A}$.

- Para cada brote de Haro 15, y cuando fue posible disponer de las líneas más intensas, se determinó la abundancia de oxígeno a partir del análisis de los diferentes parámetros empíricos: $\mathrm{O}_{23}, \mathrm{~S}_{23}, \mathrm{SO}_{23}, \mathrm{O}_{3} \mathrm{~N}_{2}, \mathrm{~S}_{3} \mathrm{O}_{3}, \mathrm{~N}_{2}$ y $\mathrm{Ar}_{3} \mathrm{O}_{3}$. Las abundancias totales de oxígeno estimadas con los diferentes parámetros empíricos, en general, mostraron valores consistentes con las abundancias derivadas usando las temperaturas obtenidas ya sea de los modelos y relaciones empíricas o por métodos directos, excepto en determinados casos donde los valores de las abundancias determinadas con algunos parámetros dan valores que sobreestiman o subestiman la abundancia total de oxígeno obtenida previamente. Cabe destacar que las relaciones empíricas usadas tanto para los parámetros empíricos como para los parámetros $\eta$ y $\eta$ ' fueron derivadas a partir de medidas para regiones completas y que nunca se ha hecho un análisis y/o determinación por componentes. Este es un trabajo que merece una discusión y un tratamiento más completo que está más allá de lo que se puede realizar con los presentes datos.

Los resultados de esta Tesis amplian de distintas formas el estudio de las Regiones HiI Gigantes. Si bien no es la primera vez que se combina la información cinemática - que permite separar componentes indistinguibles en espectroscopía de baja resolución - junto con un análisis detallado de las propiedades físicas de cada componente, este trabajo presenta una mayor completitud frente a otros trabajos publicados dada la gran cantidad de líneas analizadas, entre las que se encuentran las débiles líneas aurorales. Además, a esto se suma la posibilidad de descomponer sus perfiles en más de una componente angosta y una componente ancha. Para ello, he debido avanzar sobre las técnicas convencionales de análisis espectral, desarrollando una metodología de trabajo original, necesaria para llevar esta investigación a un resultado convincente. 


\section{Trabajo futuro}

La influencia de las estrellas masivas deja su impronta en la fase gaseosa, principalmente excitando, ionizando y modificando estructuralmente el ISM a partir de su radiación UV y vientos. La intensidad de las líneas de emisión del gas ionizado permite analizar las propiedades físicas de dichas regiones, su dinámica interna, y caracterizar, utilizándolas como sondas, la cinemática de las galaxias que las albergan. Siguiendo esta línea y teniendo en cuenta los progresos más recientes en este campo, especialmente la nueva información que ofrecen los grandes telescopios, el plan de trabajo a futuro se estructura en dos objetivos principales:

- Continuar la identificación y consiguiente análisis de Regiones Hir Gigantes en galaxias cercanas. La identificación es posible mediante espectroscopía de alta resolución que permite verificar la naturaleza supersónica de la cinemática del gas ionizado. Por otro lado, estudiar la estructura cinemática de dichas regiones con espectroscopía 3D que permita combinar información cinemática y espacial, con una unívoca determinación de los nodos individuales que contribuyen al perfil global observado.

- Definir la naturaleza y propiedades físicas de los brotes de formación estelar masiva, como así también entender los mecanismos que permiten su retroalimentación y la formación de nuevas generaciones de estrellas que producen a la vez, el enriquecimiento químico del Universo Local. El análisis de los parámetros físicos tales como densidad electrónica, temperatura electrónica, y composición química permitirá caracterizar los brotes de formación estelar más extremos analizando su entorno.

Se dispone de espectros de alta resolución obtenidos con los telescopios de 2.5 y $6.5 \mathrm{~m}$ del Observatorio de Las Campanas (LCO) para la detección de Regiones Hir Gigantes en más galaxias espirales y BCDs. Recientemente, se re-observaron dos de los brotes de la galaxia Haro 15 (A y B) con un mejor cociente $\mathrm{S} / \mathrm{N}$, con lo que se espera poder detectar las débiles líneas aurorales y poder realizar ajustes en estas líneas que sean independientes de las soluciones de las líneas más intensas.

Para estudiar comportamientos cinemáticos complejos en las regiones de formación estelar haré uso de las facilidades instrumentales de espectroscopia 3D de los Telescopios Gemini, tanto en el rango óptico (GMOS), como en el infrarrojo cercano (NIFS). Cuento con observaciones asignadas con alta prioridad (Banda 1) para obtener espectroscopía 3D de campo integrado en una región de formación estelar que presenta más de una componente en el perfil de sus líneas de emisión. La propuesta aceptada plantea hacer uso de la alta calidad de imágenes de los telescopios Gemini en su modo IFU (sigla en inglés de Integral Field Unit) para

mapear el campo de velocidades. De esta manera espero dilucidar si el perfil, aparentemente supersónico de algunas regiones HII gigantes puede resolverse en varias componentes, cada 
una de ellas con distintas velocidades. También, junto a Guillermo Bosch y Guillermo Hägele, obtuve tiempo de observación durante el semestre 2009A, con el cual planteamos mejorar la resolución estudiando regiones visibles con Gemini Norte utilizando la resolución espacial al límite de difracción en el infrarrojo cercano, utilizando óptica Adaptable con estrella guía laser en el instrumento GNIRS. El uso de óptica Adaptable permite obtener imágenes de la misma calidad que la del Telescopio Espacial (FWHM $\approx 0.08$ segundos de arco) en un telescopio de 8 metros de diámetro. Esto nos permitirá estudiar la estructura cinemática de dichas regiones con una resolución sin precedentes necesaria para distinguir la presencia de distintas componentes, con velocidades diferentes, que puedan contribuir al ancho observado en el perfil de la emisión global.

Se pretende ampliar la muestra tanto de Regiones Hiı Gigantes como de galaxias Hiı para las que se pueda obtener una abundancia precisa utilizando lo que se conoce como el método directo. Usaremos los datos estudiados en Firpo et al. (2005, 2010) y nuevas observaciones de regiones HiI en otras galaxias BCDs. Esto permitirá producir y calibrar relaciones empíricas entre las diferentes temperaturas de línea que reemplazarían a las que se utilizan actualmente y que están basadas en secuencias de modelos de fotoionización muy simples, y pobremente contrastados, debido a la falta de datos idóneos. Para ello, se requiere el uso de espectrógrafos de amplia cobertura espectral y resolución espectral intermedia. La muestra debe ser diseñada para abarcar objetos en los extremos bajo y alto de temperaturas electrónicas. Esta cobertura total en temperaturas electrónicas proveerá una limitación muy necesaria de la estructura en temperaturas de las galaxias Hiı.

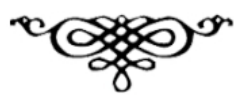




\section{Bibliografía}

Allende Prieto, C., Lambert, D. L., and Asplund, M.: 2001, ApJ 556, L63

Alloin, D., Collin-Souffrin, S., Joly, M., and Vigroux, L.: 1979, A $\mathcal{E} A$ 78, 200

Alves, J., Lombardi, M., and Lada, C. J.: 2007, A\&\&A 462, L17

Amorín, R. O., Pérez-Montero, E., and Vílchez, J. M.: 2010, ApJ 715, L128

Asplund, M., Grevesse, N., and Sauval, A. J.: 2005, in T. G. Barnes III \& F.Ñ. Bash (ed.), Cosmic Abundances as Records of Stellar Evolution and Nucleosynthesis, Vol. 336 of Astronomical Society of the Pacific Conference Series, pp 25-+

Barker, T.: 1980, ApJ 240, 99

Bate, M. R., Bonnell, I. A., and Bromm, V.: 2003, MNRAS 339, 577

Benjamin, R. A., Skillman, E. D., and Smits, D. P.: 1999, ApJ 514, 307

Bohlin, R. C., Dickinson, M. E., and Calzetti, D.: 2001, ApJ 122, 2118

Bosch, G., Terlevich, E., and Terlevich, R.: 2002, MNRAS 329, 481

Cairós, L. M., Caon, N., Zurita, C., Kehrig, C., Weilbacher, P., and Roth, M.: 2009, A\&A 507, 1291

Cairós, L. M., Vílchez, J. M., González Pérez, J.Ñ., Iglesias-Páramo, J., and Caon, N.: 2001, ApJS 133, 321

Chu, Y. and Kennicutt, Jr., R. C.: 1994, ApJ 425, 720

De Robertis, M. M., Dufour, R. J., and Hunt, R. W.: 1987, Royal Astronomical Society of Canada, Journal 81, 195

de Vaucouleurs, G., de Vaucouleurs, A., Corwin, H. G., Buta, R. J., Paturel, G., and Fouque, P.: 1991, Third Reference Catalogue of Bright Galaxies, version 3.9, vol. p.

Denicoló, G., Terlevich, R., and Terlevich, E.: 2002, MNRAS 330, 69

Díaz, Á. I.: 1998, Ap\&SS 263, 143

Díaz, A. I. and Pérez-Montero, E.: 2000, MNRAS 312, 130

Díaz, Á. I., Terlevich, E., Castellanos, M., and Hägele, G. F.: 2007, MNRAS 382, 251(D07)

Díaz, A. I., Terlevich, E., Pagel, B. E. J., Vúilchez, J. M., and Edmunds, M. G.: 1987, MNRAS 226, 19

Drissen, L., Moffat, A. F. J., and Shara, M. M.: 1993, Astron. J. 105, 1400 
Esteban, C. and Vilchez, J. M.: 1992, ApJ 390, 536

Feinstein, C.: 1997, Astrophys. J. Suppl. S. 112, 29

Firpo, V., Bosch, G., Hägele, G. F., and Morrell, N.: 2010, MNRAS 406, 1094

Firpo, V., Bosch, G., and Morrell, N.: 2005, MNRAS 356, 1357

Firpo, V., Hägele, G. F., Bosch, G., and Morrell, N.: 2011, MNRAS, aceptado

French, H. B.: 1980, ApJ 240, 41

García-Benito, R.: 2009, Ph.D. thesis, Universidad Autonóma de Madrid

García-Benito, R., Díaz, A., Hägele, G. F., Pérez-Montero, E., López, J., Vílchez, J. M., Pérez, E., Terlevich, E., Terlevich, R., and Rosa-González, D.: 2010, MNRAS 408, 2234

García-Lorenzo, B., Cairós, L. M., Caon, N., Monreal-Ibero, A., and Kehrig, C.: 2008, ApJ 677, 201

Garnett, D. R.: 1992, AJ 103, 1330

Gil de Paz, A., Madore, B. F., and Pevunova, O.: 2003, ApJS 147, 29

González-Delgado, R. M., Perez, E., Tenorio-Tagle, G., Vilchez, J. M., Terlevich, E., Terlevich, R., Telles, E., Rodriguez-Espinosa, J. M., Mas-Hesse, M., Garcia-Vargas, M. L., Diaz, A. I., Cepa, J., and Castaneda, H.: 1994, ApJ 437, 239

Grevesse, N. and Sauval, A. J.: 1998, Space Science Reviews. 85, 161

Hägele, G. F.: 2008, Ph.D. thesis, Universidad Autónoma de Madrid

Hägele, G. F., Díaz, Á. I., Cardaci, M. V., Terlevich, E., and Terlevich, R.: 2007, MNRAS 378, 163

Hägele, G. F., Díaz, Á. I., Cardaci, M. V., Terlevich, E., and Terlevich, R.: 2009, MNRAS 396, 2295

Hägele, G. F., Díaz, Á. I., Cardaci, M. V., Terlevich, E., and Terlevich, R.: 2010, MNRAS 402, 1005

Hägele, G. F., Díaz, A. I., Terlevich, E., Terlevich, R., Pérez-Montero, E., and Cardaci, M. V.: 2008, MNRAS 383, 209 (H08)

Hägele, G. F., García-Benito, R., Pérez-Montero, E., Díaz, A. I., Cardaci, M. V., Firpo, V., Terlevich, E., and Terlevich, R.: 2011, MNRAS, aceptado

Hägele, G. F., Pérez-Montero, E., Díaz, A. I., Terlevich, E., and Terlevich, R.: 2006, MNRAS 372, 293 (H06)

Haro, G.: 1956, Boletin de los Observatorios Tonantzintla y Tacubaya 2, 8

Hennebelle, P. and Chabrier, G.: 2008, ApJ 684, 395

Holweger, H.: 2001, in R. F. Wimmer-Schweingruber (ed.), Joint SOHO/ACE workshop "Solar and Galactic Composition", Vol. 598 of American Institute of Physics Conference Series, pp 23-30

Homeier, N. L. and Gallagher, J. S.: 1999, ApJ 522, 199

Hoyos, C. and Díaz, A. I.: 2006, MNRAS 365, 454

Hoyos, C., Guzmán, R., Bershady, M. A., Koo, D. C., and Díaz, A. I.: 2004, AJ 128, 1541

Izotov, Y. I., Stasińska, G., Guseva, N. G., and Thuan, T. X.: 2004, Aש̋A 415, 87 
James, B. L., Tsamis, Y. G., Barlow, M. J., Westmoquette, M. S., Walsh, J. R., Cuisinier, F., and Exter, K. M.: 2009, MNRAS 398, 2

Kewley, L. J. and Ellison, S. L.: 2008, ApJ 681, 1183

Kingdon, J. and Ferland, G. J.: 1995, ApJ 442, 714

Klessen, R. S.: 2001, ApJ 556, 837

Kobulnicky, H. A., Kennicutt, Jr., R. C., and Pizagno, J. L.: 1999, ApJ 514, 544

Kunth, D. and Östlin, G.: 2000, A\&\&A Rev 10, 1

Kunth, D. and Sargent, W. L. W.: 1983, ApJ 273, 81

López-Sánchez, Á. R.: 2010, A\&\&A 521, A63+

López-Sánchez, Á. R. and Esteban, C.: 2008, AछA 491, 131

López-Sánchez, Á. R. and Esteban, C.: 2009a, Ap\&SS 324, 355

López-Sánchez, A. R. and Esteban, C.: 2009b, A\&3A 508, 615

López-Sánchez, Á. R. and Esteban, C.: 2010, åp 516, A104+

Lowenthal, J. D., Koo, D. C., Guzman, R., Gallego, J., Phillips, A. C., Faber, S. M., Vogt, N. P., Illingworth, G. D., and Gronwall, C.: 1997, ApJ 481, 673

Luridiana, V., Peimbert, M., and Leitherer, C.: 1999, ApJ 527, 110

Malumuth, E. M., Waller, W. H., and Parker, J. W.: 1996, Astron. J. 111, 1128

Massey, P. and Hunter, D. A.: 1998, Astrophys. J. 493, 180

McGaugh, S. S.: 1991, ApJ 380, 140

McKee, C. F. and Tan, J. C.: 2003, ApJ 585, 850

Medina Tanco, G. A., Sabalisck, N., Jatenco-Pereira, V., and Opher, R.: 1997, Astrophys. J. 487, 163

Melnick, J.: 1977, Astrophys. J. 213, 15

Melnick, J., Tenorio-Tagle, G., and Terlevich, R.: 1999, MNRAS 302, 677

Melnick, J., Terlevich, R., and Eggleton, P. P.: 1985a, MNRAS 216, 255

Melnick, J., Terlevich, R., and Moles, M.: 1985b, Revista Mexicana de Astronomía y Astrofísica 11, 91

Melnick, J., Terlevich, R., and Terlevich, E.: 2000, MNRAS 311, 629

Mendez, D. I. and Esteban, C.: 1997, ApJ 488, 652

Miller, J. S. and Mathews, W. G.: 1972, ApJ 172, 593

Muñoz-Tuñón, C., Gavryusev, V., and Castañeda, H. O.: 1995, Astron. J. 110, 1630, (MGC95)

Muñoz-Tuñón, C., Tenorio-Tagle, G., Castañeda, H. O., and Terlevich, R.: 1996, AJ 112, 1636

Olive, K. A. and Skillman, E. D.: 2001, NewA 6, 119 
Olive, K. A. and Skillman, E. D.: 2004, ApJ 617, 29

Osterbrock, D. E.: 1989, in Astrophysics of gaseous nebulae and active galactic nuclei. Mill Valley, CA, University Science Books, 1989

Padoan, P. and Nordlund, A.: 2009, ArXiv e-prints

Pagel, B. E. J., Edmunds, M. G., Blackwell, D. E., Chun, M. S., and Smith, G.: 1979, MNRAS 189, 95

Pagel, B. E. J., Simonson, E. A., Terlevich, R. J., and Edmunds, M. G.: 1992, MNRAS 255, 325

Peimbert, M.: 1967, ApJ 150, 825

Peimbert, M. and Costero, R.: 1969, Boletin de los Observatorios Tonantzintla y Tacubaya 5, 3

Pérez-Montero, E.: 2003, Ph.D. thesis, Universidad Autonóma de Madrid

Pérez-Montero, E. and Díaz, A. I.: 2003, MNRAS 346, 105

Pérez-Montero, E. and Díaz, A. I.: 2005, MNRAS 361, 1063

Pérez-Montero, E., Díaz, A. I., Vílchez, J. M., and Kehrig, C.: 2006, A\&\&A 449, 193

Pérez-Montero, E., García-Benito, R., Hägele, G. F., and Díaz, Á. I.: 2010, MNRAS 404, 2037

Pérez-Montero, E., Hägele, G. F., Contini, T., and Díaz, Á. I.: 2007, MNRAS 381, 125

Pérez-Montero, E., Vílchez, J. M., Cedrés, B., Hägele, G. F., Mollá, M., García-Benito, R., Díaz, A. I., Kehrig, C., and Martín-Gordón, D.: 2011, A\&A, enviado

Pettini, M. and Pagel, B. E. J.: 2004, MNRAS 348, L59

Pilyugin, L. S.: 2007, MNRAS 375, 685 (P07)

Relaño, M. and Beckman, J. E.: 2005, A\&A 430, 911

Rodríguez, M. and Rubin, R. H.: 2004, in P.-A. Duc, J. Braine, \& E. Brinks (ed.), Recycling Intergalactic and Interstellar Matter, Vol. 217 of IAU Symposium, pp 188-+

Roy, J. R., Arsenault, R., and Joncas, G.: 1986, Astrophys. J. 300, 624, (RAJ86)

Rozas, M., Richer, M. G., López, J. A., Relaño, M., and Beckman, J. E.: 2006, A\&3A 455, 539

Sargent, W. L. W. and Searle, L.: 1970, ApJ 162, L155+

Searle, L. and Sargent, W. L. W.: 1972, ApJ 173, 25

Shaw, R. A. and Dufour, R. J.: 1995, PASP 107, 896

Shi, F., Kong, X., Li, C., and Cheng, F. Z.: 2005, A\&3A 437, 849

Simpson, R. J., Nutter, D., and Ward-Thompson, D.: 2008, MNRAS 391, 205

Skillman, E. D.: 1989, ApJ 347, 883

Slavin, J. D., Shull, J. M., and Begelman, M. C.: 1993, ApJ 407, 83

Smith, M. G. and Weedman, D. W.: 1970, Astrophys. J. 160, 65 
Smith, R. J., Clark, P. C., and Bonnell, I. A.: 2009a, MNRAS 396, 830

Smith, R. J., Longmore, S., and Bonnell, I.: 2009b, MNRAS 400, 1775

Stasińska, G.: 1978, A\&BA 66, 257

Stasińska, G.: 1990, A\&AS 83, 501

Stasińska, G.: 2006, A\&A 454, L127

Stasińska, G., Schaerer, D., and Leitherer, C.: 2001, A\&̈A 370, 1

Storchi-Bergmann, T., Calzetti, D., and Kinney, A. L.: 1994, ApJ 429, 572

Storey, P. J. and Hummer, D. G.: 1995, MNRAS 272, 41

Tayal, S. S. and Gupta, G. P.: 1999, ApJ 526, 544

Tenorio-Tagle, G., Muñoz-Tuñón, C., and Cox, D. P.: 1993, Astrophys. J. 418, 767

Terlevich, E., Díaz, A. I., Terlevich, R., González-Delgado, R. M., Pérez, E., and García Vargas, M. L.: 1996, MNRAS 279, 1219

Terlevich, R. and Melnick, J.: 1981, Mon. Not. R. Astron. Soc. 195, 839

Terlevich, R., Melnick, J., Masegosa, J., Moles, M., and Copetti, M. V. F.: 1991, A\&AAs 91, 285

Terlevich, R., Silich, S., Rosa-González, D., and Terlevich, E.: 2004, MNRAS 348, 1191

Tilley, D. and Pudritz, R.: 2005, Royal Astronomical Society of Canada, Journal 99, 132

Vilchez, J. M. and Esteban, C.: 1996, MNRAS 280, 720

Vilchez, J. M. and Pagel, B. E. J.: 1988, MNRAS 231, 257

Westmoquette, M. S., Exter, K. M., Smith, L. J., and Gallagher, J. S.: 2007a, MNRAS 381, 894

Westmoquette, M. S., Gallagher, J. S., Smith, L. J., Trancho, G., Bastian, N., and Konstantopoulos, I. S.: 2009, ApJ 706, 1571

Westmoquette, M. S., Smith, L. J., Gallagher, J. S., and Exter, K. M.: 2007b, MNRAS 381, 913

Zwicky, F.: 1965, ApJ 142, 1293 



\section{Agradecimientos}

Quiero expresar mi agradecimiento:

A mi director de Tesis, Guillermo Bosch por su generosidad al brindarme la oportunidad de ser parte del Grupo de Estrellas Masivas, y de compartir su capacidad y experiencia científica en un marco de confianza, afecto y amistad, fundamentales para la concreción de este trabajo. También le agradezco haberme dado la libertad y todos los medios adecuados para la realización de esta Tesis. Lo humano prevalece por sobre todas las cosas. Muchas Gracias Guille!!

A mi co-director de Tesis, Guillermo Hägele quien supo compartir, con una disposición sin igual, toda su experiencia de trabajo adquirida en el grupo del Departamento de Física Teórica de la Universidad de Madrid, y quien me brindó la oportunidad de acercarme a conocer a Ángeles y a su grupo de trabajo. Y como nombrar a Guiye sin nombrar a su familia, Moni y Vale, quienes me dieron todo su cariño y afecto en las estadías en Madrid, en particular a Moni siempre presente ayudando con scripts y trucos computacionales. Gracias "familia"!!

A Nidia Morrell, por enseñarme las técnicas de observación, invitarme a participar de sus proyectos de observación y brindarme la oportunidad de obtener los excelentes datos observacionales que sin ellos, toda esta Tesis no se hubiera podido concretar. Por todas esas increíbles noches estrelladas en Las Campanas ... Gracias Nidia!

A Ángeles Díaz, por su generosidad científica y valiosas críticas al discutir el análisis y los resultados de este trabajo y por invitarme a participar del Proyecto "Estallidos y su huella en la evolución cósmica de las galaxias" con el cual pude viajar en más de una oportunidad a la ciudad de Madrid a realizar las estadías de investigación. Gracias Ángeles!

A mi "compañera de Tesis", Cecilia Fariña, por su presencia incondicional, su permanente disposición y desinteresada ayuda y por sobre todo su amistad.

A Elena y Roberto Terlevich por su calidez y por sus valiosas sugerencias durante el desarrollo de este trabajo.

A Virpi Niemela, por abrirme las puertas del grupo y aceptar ser mi aval en los comienzos de la beca de la UNLP. Se te extraña mucho Virpi!

A Roberto Venero, Amalia Meza y Pablo Cincotta por su permanente disposición y desinteresada ayuda.

A mis amigos del Observatorio (incluyendo algunas parejas de amigas/os) por su continuo y afectuoso aliento. Si tuviera que especificar a todos me llevaría un capítulo entero de esta Tesis, pero cada uno de ustedes sabe reconocerse en estas palabras.

A mis amigas María Paula Natali, María Florencia Pan y a mis amigas de Domínico por su cariño, comprensión y constante estímulo.

A mis amigos del Ministerio por acompañarme en todos los momentos importantes. 
A mis padres por enseñarme que la perseverancia y el esfuerzo son el camino para lograr objetivos. Y a mi familia por enseñarme a enfrentar los obstáculos con alegría y afecto.

A la Facultad de Ciencias Astronómicas y Geofísicas por brindarme el espacio para trabajar y la calidad académica necesaria para alcanzar este título. Y un agradecimiento al personal no docente de la Facultad por la ayuda brindada durante todo este tiempo.

A la Universidad Nacional de La Plata por haberme dado la posibilidad de tener una beca de investigación para realizar todo el trabajo de Tesis.

Al Director y personal técnico del Observatorio de Las Campanas (LCO), Chile, por su generosa hospitalidad y soporte técnico durante los turnos de observación.

Y un especial agradecimiento al jurado evaluador de la Tesis, Cristina Cappa, Enrique Pérez-Montero y Lydia Cidale, por sus valiosas sugerencias y correcciones para mejorar esta Tesis.

A todos y cada uno ... Muchas Gracias!!

Tarda en llegar

$Y$ al final, al final

Hay recompensa

En la zona de promesas

(Zona de promesas - G.Ceratti)

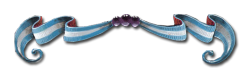




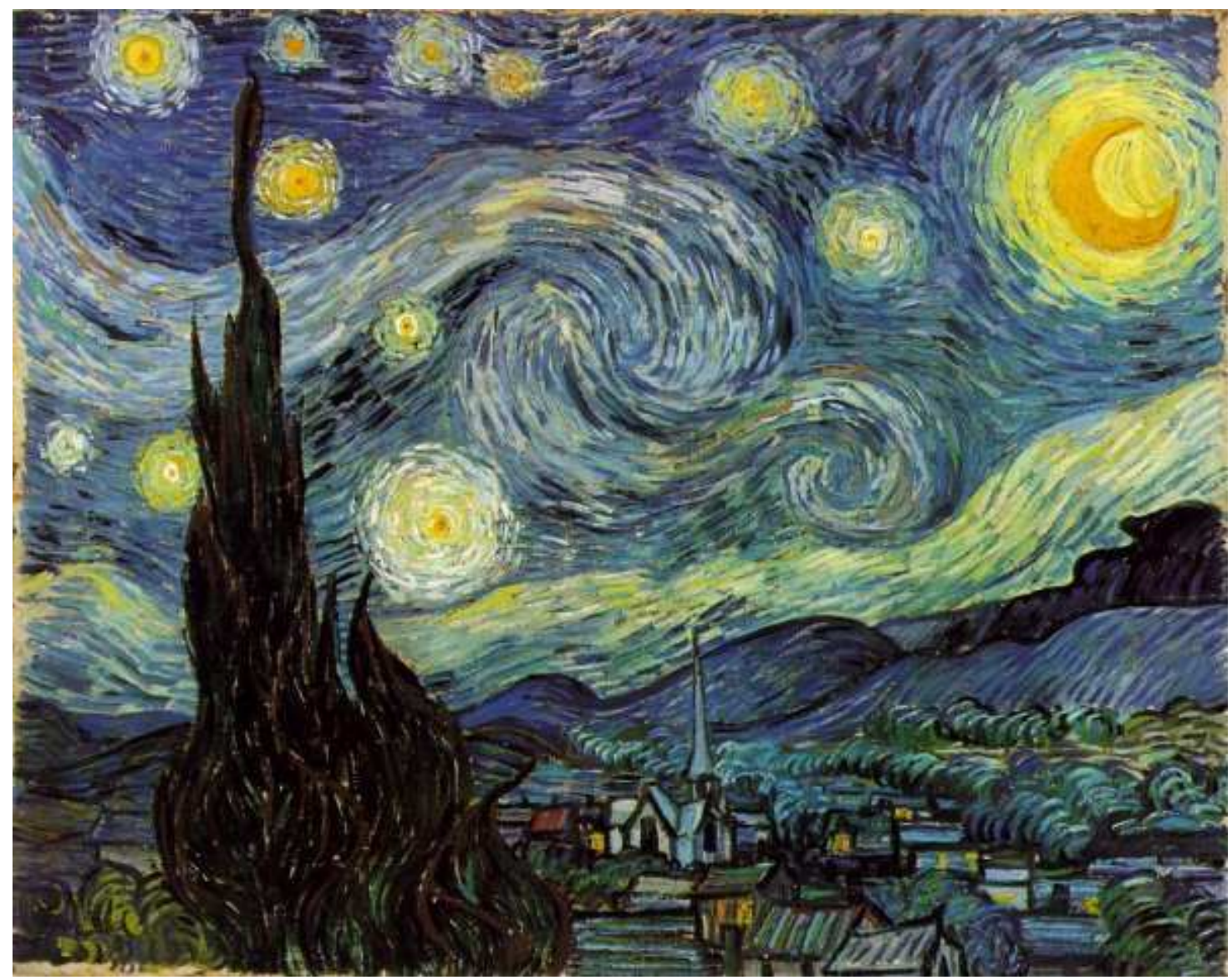

"Cuando siento una necesidad de religión salgo de noche para pintar las estrellas" Vincent Van Gogh 
